\title{
Resolução de Problemas e Representações Semióticas: uma experiência no Ensino Médio inspirada no Rali Matemático
}

\author{
Marília Prado
}

Dissertação apresentada ao Instituto de Matemática e

Estatística da Universidade de São Paulo para

obtenção do título de Mestre em Ciências

Programa: Mestrado Profissional em Ensino de

Matemática

Orientadora: Profa. Dra. Ana Paula Jahn

Durante o desenvolvimento deste trabalho o autor recebeu auxílio financeiro da CAPES

São Paulo, julho de 2015 


\section{Resolução de Problemas e Representações Semióticas: uma experiência no Ensino Médio inspirada no Rali Matemático}

Esta versão da dissertação contém as correções e alterações sugeridas pela Comissão Julgadora durante a defesa da versão original do trabalho, realizada em 01/07/2015. Uma cópia da versão original está disponível no Instituto de Matemática e Estatística da Universidade de São Paulo.

Comissão Julgadora:

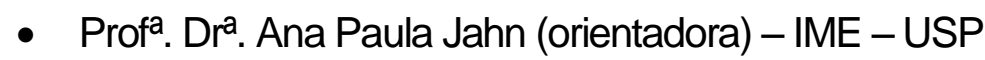

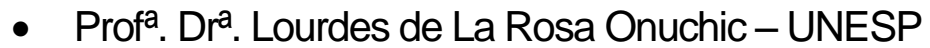

- Prof $\stackrel{\text { a }}{\text {. Dr }}$ - Cláudia Cueva Candido - IME - USP 


\section{Agradecimentos}

À Profa. Dra. Ana Paula Jahn, pela dedicação, confiança e pelo aprendizado.

Às Professoras, Dra. Lourdes de la Rosa Onuchic e Dra. Cláudia Cueva Candido, pelas valiosas sugestões e contribuições na qualificação e por terem aceitado participar da banca de defesa.

E ainda, um agradecimento especial à Profa. Cláudia, pela oportunidade de participar do Projeto Observatório da Educação, beneficiando-me com o apoio financeiro da CAPES.

À professora Narahan Dib Fracalanza, pela colaboração na realização do experimento.

Aos alunos que participaram do experimento, pela receptividade.

Aos professores do Programa de Pós-Graduação em Mestrado Profissional em Ensino de Matemática do IME - USP, pelas contribuições ao longo de todo o curso.

Aos amigos Liliane, Cynthia e Douglas, companheiros de estudo.

À minha família, pelo incentivo, apoio, contribuição e pela compreensão em muitas de minhas ausências. 


\section{Resumo}

PRADO, M. Resolução de Problemas e Representações Semióticas: uma experiência no Ensino Médio inspirada no Rali Matemático. 2015. 168 f. Dissertação (Mestrado) - Instituto de Matemática e Estatística, Universidade de São Paulo, São Paulo, 2015.

Este trabalho tem como tema de estudo a Resolução de Problemas no ensino e aprendizagem da Matemática na Educação Básica e insere-se no projeto Ensino de Matemática na Escola Elementar, no âmbito do programa Observatório da Educação (OBEDUC/CAPES), desenvolvido no IME-USP. Seu objetivo é investigar de que maneira as práticas de Resolução de Problemas podem ser implementadas na sala de aula e como essas práticas são vivenciadas pelos alunos. Para tanto, propôs-se desenvolver - realizar e analisar - uma experiência em Resolução de Problemas com alunos da $1^{\text {a }}$ série do Ensino Médio de uma escola pública de São Paulo/SP, inspirada na competição internacional Rali Matemático. Em geral, durante a busca da solução de um problema em Matemática, as ideias precisam ser organizadas a partir da representação de objetos matemáticos e de relações entre eles. Com isso, entendendo que diferentes tipos de representações matemáticas são ferramentas úteis na atividade de resolução de problemas, buscamos analisar o papel de diversas representações semióticas nos processos de resolução dos alunos. A estratégia metodológica envolveu um estudo experimental de intervenção, organizado em três fases, cuja análise dos dados coletados foi de natureza qualitativa, à luz das pesquisas na área, bem como da teoria dos registros de representação semiótica de Raymond Duval. Os resultados mostraram que, mesmo sem obter respostas completas e corretas, grande parte dos grupos apresentou tentativas de representações dos tipos discutidos nas etapas iniciais do experimento, ou, ao menos, maneiras mais organizadas de tratar os dados e expor suas ideias. Conclui-se que a escolha do contexto do Rali Matemático foi validada, por ter facilitado a implementação das atividades baseadas na Resolução de Problemas, nas quais os alunos foram participantes ativos nos processos de resolução e reconheceram o importante papel das representações semióticas nesse tipo de situação.

Palavras-chave: Resolução de Problemas. Ensino Médio. Rali Matemático. Representação semiótica. 


\section{Abstract}

PRADO, M. Problem Solving and Semiotic Representations: an experience at the secondary school based on Mathematical Rally. 2015. 168 f. Dissertação (Mestrado) - Instituto de Matemática e Estatística, Universidade de São Paulo, São Paulo, 2015.

The topic of this research is Problem Solving in teaching and learning Mathematics in primary education. It fits into the project Ensino de Matemática na Escola Elementar within the program Observatório da Educação (OBEDUC/CAPES), developed by IME-USP. The goal of this study is to investigate the way in which problem solving practices can be implemented in classroom and what are students' experiences with them. For the purpose of this study, we propose to develop, realize and analyze a problem solving experience with $1^{\text {st }}$ year students of a state-run secondary school in Sao Paulo/SP, based on international competition "Mathematical Rally". In general, when solving a mathematical problem, ideas have to be organized from a representation of mathematical relations and objects. With this in mind, and understanding that different types of mathematical representations are useful tools in problem solving activities, this study investigates the role of different semiotic representations in students' problem-solving processes. Therefore, the methodology used was involved a 3-phase experimental intervention study with qualitative data analysis based on research in this area, as well as on Raymond Duval's theory of semiotic representation registers. Even though the right answers were not found, the research points that most of groups tried to represent similarly of previous stage, or at least more organized ways to deal with data and expose their ideas. It can be concluded that the choice of "Math Rally" as context was validated as it facilitated the use of activities based on problem solving. The students actively participated of the solving process and understood the role of semiotic representations on similar kind of situations.

Key words: Semiotic Representation. Problem solving. Secondary school. Mathematical Rally. 
Sumário

Lista de Abreviações …….............................................................................. vi



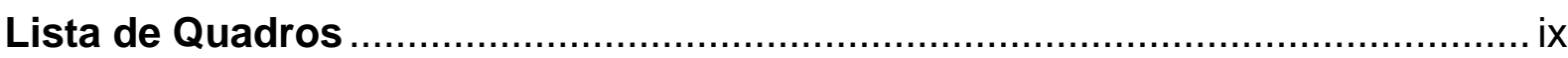

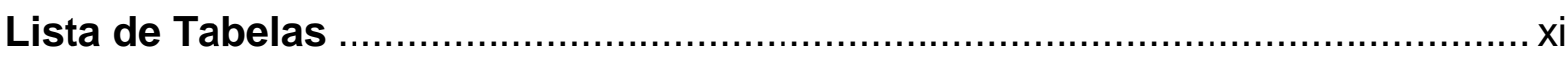

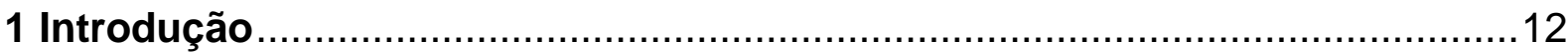

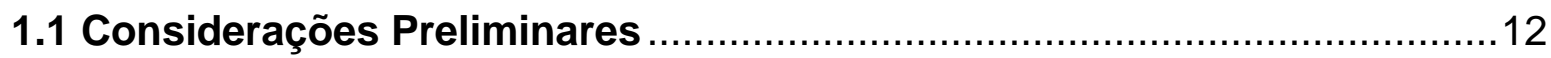

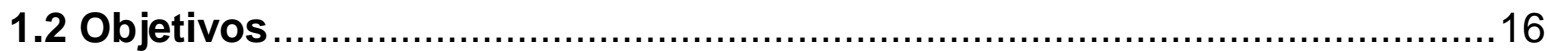

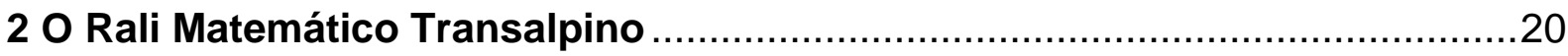

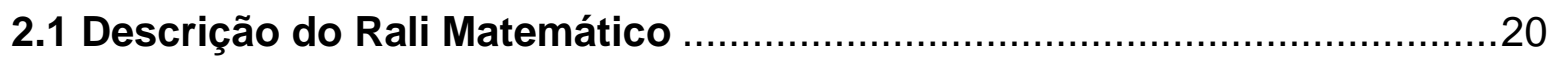



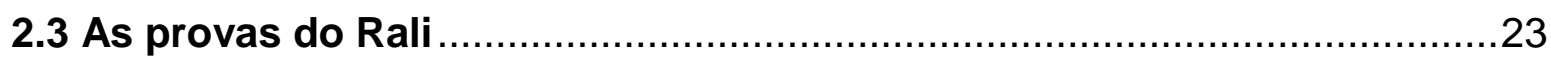



3 Resolução de Problemas em Educação Matemática ........................................30

3.1 Resolução de Problemas como metodologia ..........................................30

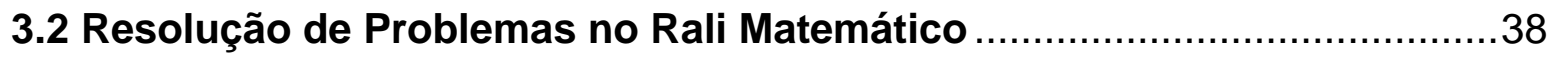

4 Representações na Resolução de Problemas ..............................................4

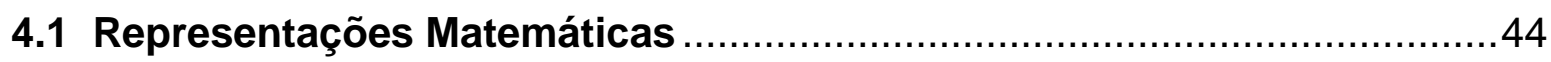

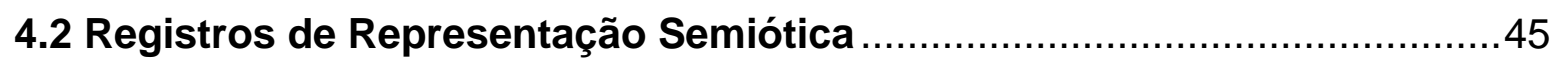

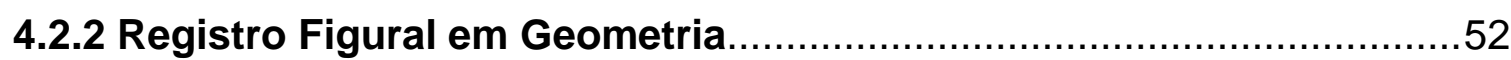

5 Metodologia

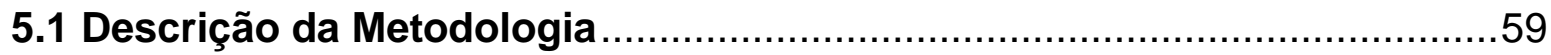

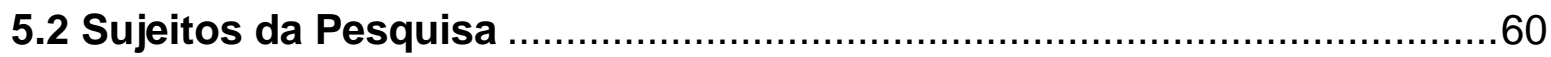

5.3 Apresentação do Dispositivo Experimental ...........................................62

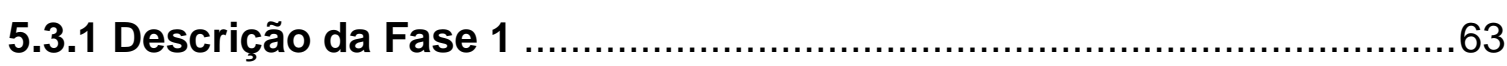

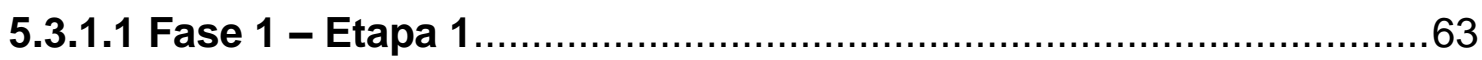

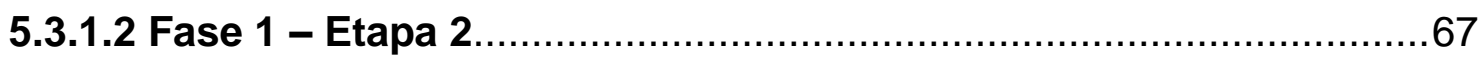

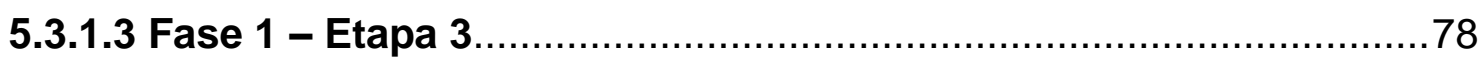

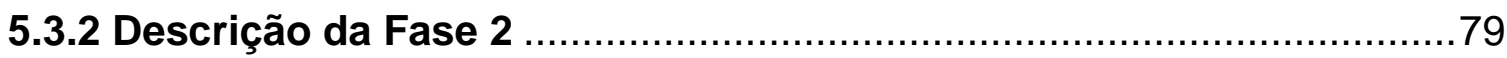

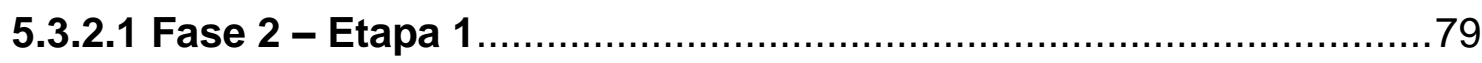

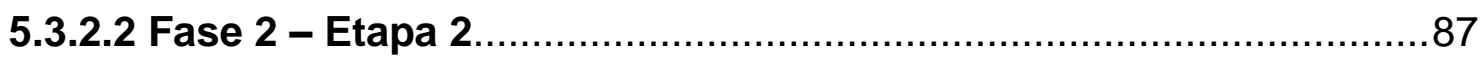


5.3.3 Descrição da Fase 3

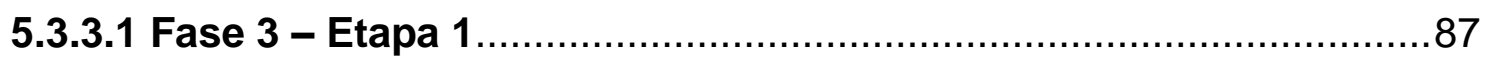

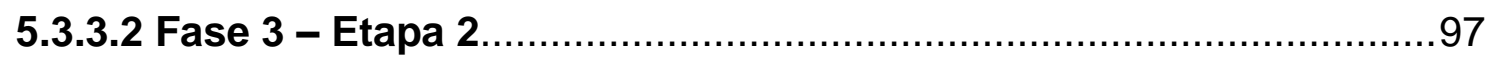

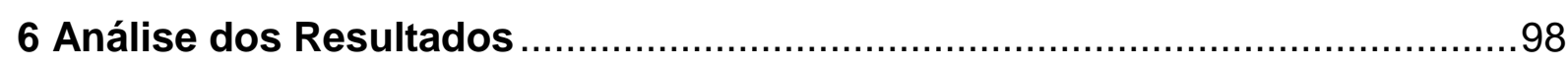

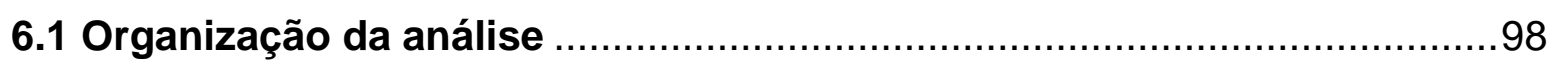

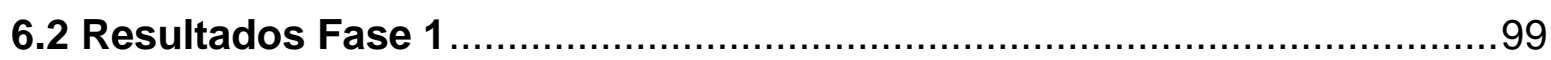

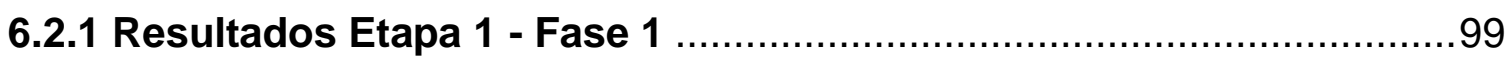



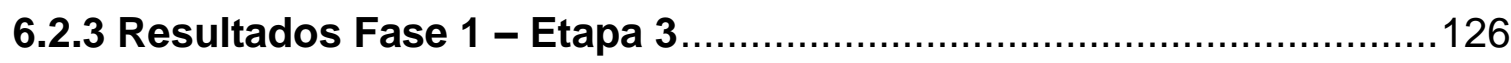

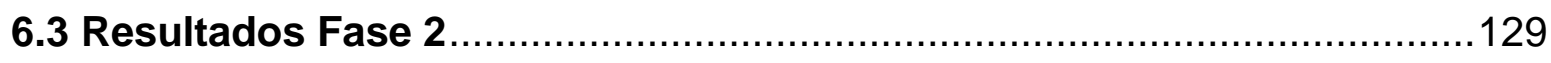

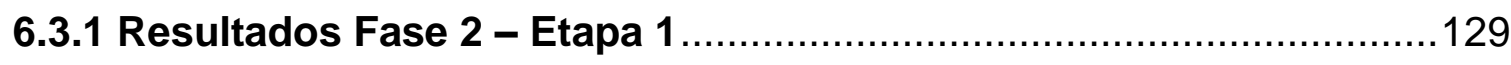

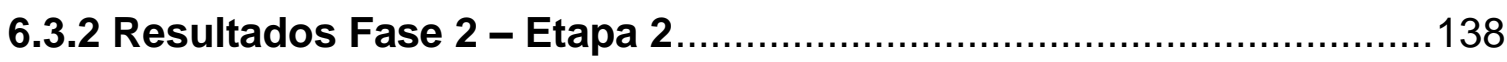

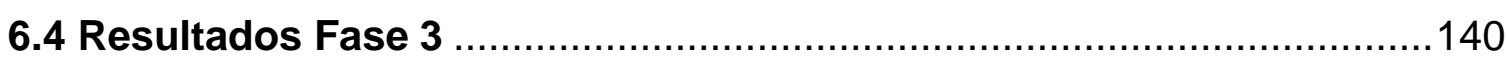

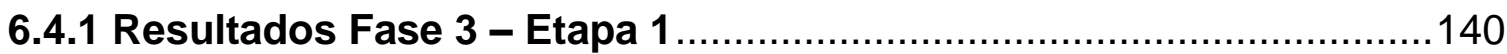

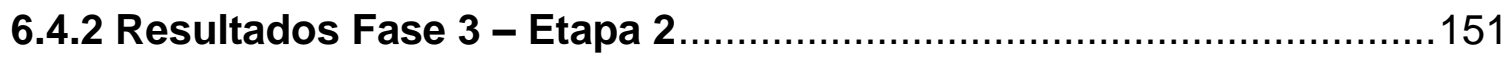

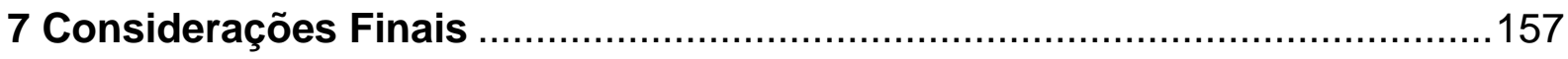

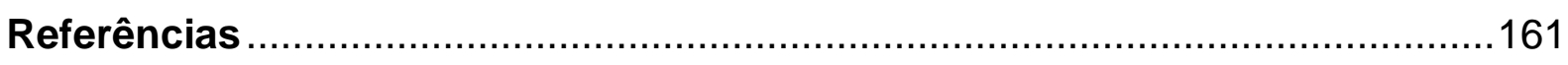




\section{Lista de Abreviações}

ARMT - Associação Rali Matemático Transalpino

NCTM - National Council of Teachers of Mathematics

OBEDUC - Observatório da Educação

OBMEP - Olimpíada Brasileira de Matemática das Escolas Públicas

PCN - Parâmetros Curriculares Nacionais

PCN+ - Ensino Médio, Orientações Educacionais Complementares aos Parâmetros

Curriculares Nacionais

RMT - Rali Matemático Transalpino

RP - Resolução de Problemas

SARESP - Sistema de Avaliação de Rendimento Escolar do Estado de São Paulo 


\section{Lista de Figuras}

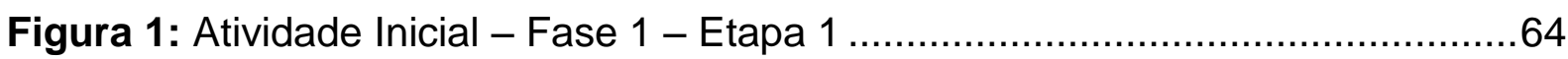

Figura 2: Solução 1, Questão 2, Atividade Inicial - Fase 1 - Etapa 1 ....................65

Figura 3: Solução 2, Questão 2, Atividade Inicial - Fase 1 - Etapa 1 ....................66

Figura 4: Questionário Inicial - Fase 1 - Etapa 1 ............................................67

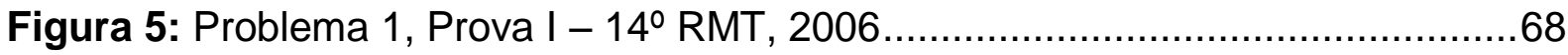



Figura 7: Problema 3, Prova I - 22ำ RMT, 2014 .......................................... 75

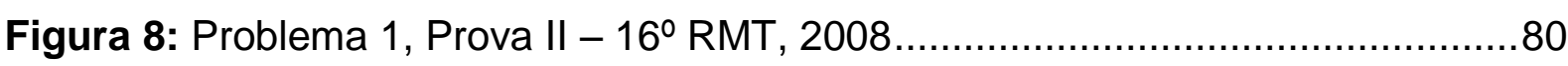

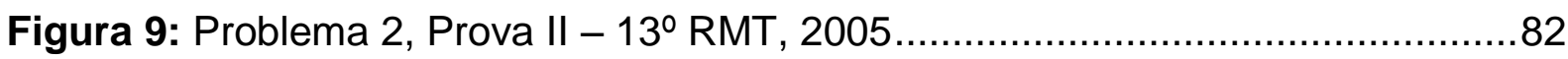

Figura 10: Problema 3, Prova II - 14ำ RMT, 2006......................................... 85

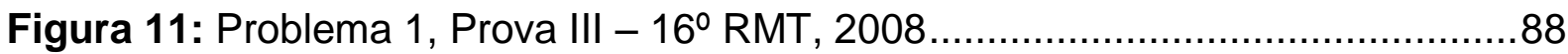

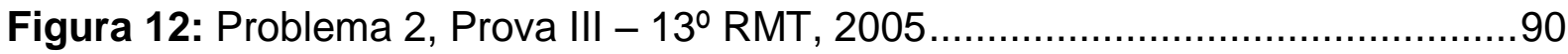

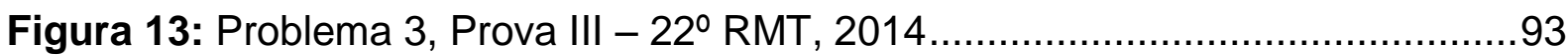

Figura 14: Construção da Solução 1, Problema 1, Prova III - Fase 3 - Etapa 1 .....96

Figura 15: Solução Problema 3, Prova III - Fase 3 - Etapa 1 .............................96

Figura 16: Questionário Final - Fase 3 - Etapa 2 .........................................97

Figura 17: Solução da Dupla D4 - Questão 1, Atividade inicial ...........................100

Figura 18: Solução da Dupla D13 - Questão 2, Atividade Inicial ..........................101

Figura 19: Solução da Dupla D10 - Questão 2, Atividade Inicial ..........................102

Figura 20: Solução da Dupla D1 - Questão 2, Atividade Inicial ...........................103

Figura 21: Solução da Dupla D5 - Questão 2, Atividade Inicial ............................104

Figura 22: Solução do Grupo G12 - Problema 1, Prova I ................................114

Figura 23: Solução do Grupo G11 - Problema 1, Prova I ...................................115

Figura 24: Solução do Grupo G2 - Problema 1, Prova I .................................116

Figura 25: Solução do Grupo G3 - Problema 1, Prova I ....................................116

Figura 26: Solução do Grupo G1 - Problema 1, Prova I .....................................117

Figura 27: Solução do Grupo G18 - Problema 1, Prova I .................................118

Figura 28: Solução do Grupo G17 - Problema 2, Prova I ...................................119

Figura 29: Solução do Grupo G16 - Problema 2, Prova I ................................120

Figura 30: Solução do Grupo G1 - Problema 2, Prova I .................................120

Figura 31: Solução do Grupo G2 - Problema 2, Prova I ..................................121 
Figura 32: Solução do Grupo G3 - Problema 2, Prova I ...................................122

Figura 33: Solução do Grupo G8 - Problema 3, Prova I .....................................123

Figura 34: Solução do Grupo G4 - Problema 3, Prova I ....................................124

Figura 35: Solução do Grupo G18 - Problema 3, Prova I ..................................125

Figura 36: Solução do Grupo G15 - Problema 1, Prova II .................................130

Figura 37: Solução do Grupo G8 - Problema 1, Prova II .....................................131

Figura 38: Solução do Grupo G5 - Problema 2, Prova II ....................................132

Figura 39: Solução do Grupo G11 - Problema 2, Prova II .................................133

Figura 40: Solução do Grupo G10 - Problema 2, Prova II ...................................134

Figura 41: Solução do Grupo G12 - Problema 3, Prova II ...................................135

Figura 42: Solução do Grupo G14 - Problema 3, Prova II ..................................135

Figura 43: Solução do Grupo G6 - Problema 3, Prova II ...................................136

Figura 44: Solução do Grupo G16 - Problema 3, Prova II ..................................137

Figura 45: Solução do Grupo G1 - Problema 3, Prova II ......................................138

Figura 46: Solução do Grupo G11 - Problema 1, Prova III ..................................141

Figura 47: Solução do Grupo G14 - Problema 1, Prova III ..................................142

Figura 48: Solução do Grupo G16 - Problema 1, Prova III .................................142

Figura 49: Solução do Grupo G2 - Problema 2, Prova III ...................................143

Figura 50: Solução do Grupo G8 - Problema 2, Prova III ...................................144

Figura 51: Solução do Grupo G13 - Problema 2, Prova III .................................145

Figura 52: Solução do Grupo G9 - Problema 2, Prova III ...................................145

Figura 53: Solução do Grupo G10 - Problema 2, Prova III .................................146

Figura 54: Solução do Grupo G11 - Problema 2, Prova III ..................................147

Figura 55: Solução do Grupo G11 - Problema 3, Prova III .................................148

Figura 56: Solução do Grupo G1 - Problema 3, Prova III ..................................149

Figura 57: Solução do Grupo G14 - Problema 3, Prova III ....................................149

Figura 58: Solução do Grupo G16 - Problema 3, Prova III .................................150

Figura 59: Solução do Grupo G13 - Problema 3, Prova III ....................................151 


\section{Lista de Quadros}

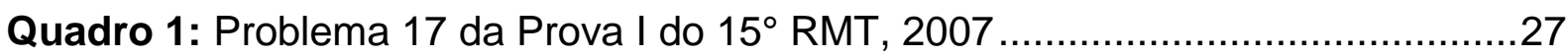

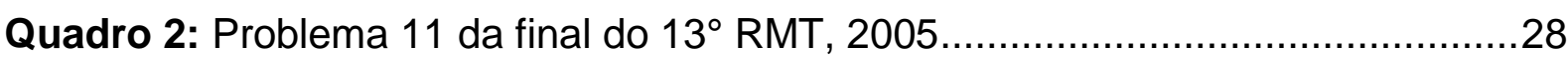

Quadro 3: Tipos de Problemas segundo Dante (2009) .......................................41

Quadro 4: Exemplos de Conversões................................................................ 49

Quadro 5: Exemplo de congruência entre representações .................................50

Quadro 6: Exemplo de não congruência entre representações .............................50

Quadro 7: Exemplo de apreensão perceptiva de uma figura ................................53

Quadro 8: Exemplo de apreensão discursiva de uma figura ................................54

Quadro 9: Exemplo de apreensão sequencial de uma figura...............................54

Quadro 10: Exemplo de apreensão operatória.............................................55

Quadro 11: Tipos de apreensões operatórias de figuras ....................................56

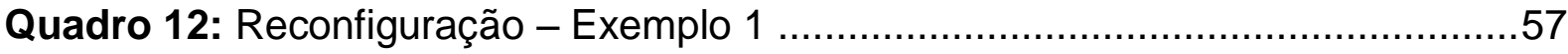

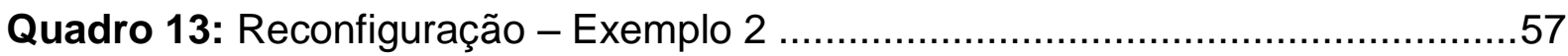



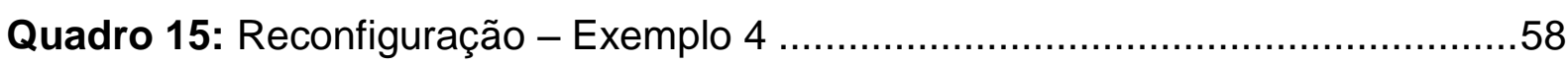

Quadro 16: Quadro sinóptico do dispositivo experimental ...................................62

Quadro 17: Respostas "sim” à Questão 1 do Questionário Inicial.......................106

Quadro 18: Respostas “não” à Questão 1 do Questionário Inicial .......................107

Quadro 19: Respostas “sim” à Questão 2 do Questionário Inicial.........................107

Quadro 20: Respostas “não” à Questão 2 do Questionário Inicial .........................108

Quadro 21: Respostas à Questão 3 do Questionário Inicial..............................109

Quadro 22: Respostas à Questão 3 do Questionário Inicial...............................109

Quadro 23: Respostas à Questão 5 do Questionário Inicial.............................110

Quadro 24: Respostas “sim” à Questão 6 do Questionário Inicial........................111

Quadro 25: Respostas “não” à Questão 6 do Questionário Inicial .........................111

Quadro 26: Respostas à Questão 1 do Questionário Final .................................151

Quadro 27: Respostas à Questão 1 do Questionário Final ................................152

Quadro 28: Respostas à Questão 1 do Questionário Final ...............................153

Quadro 29: Respostas à Questão 2 do Questionário Final, notas de 0 a 5 ..........154

Quadro 30: Respostas à Questão 2 do Questionário Final, notas de 6 a 9 ..........154

Quadro 31: Respostas à Questão 2 do Questionário Final, notas 10 ..................155 
Quadro 32: Respostas à Questão 3 do Questionário Final, pontos positivos.........155 Quadro 33: Respostas à Questão 3 do Questionário Final, pontos negativos .......156 


\section{Lista de Tabelas}

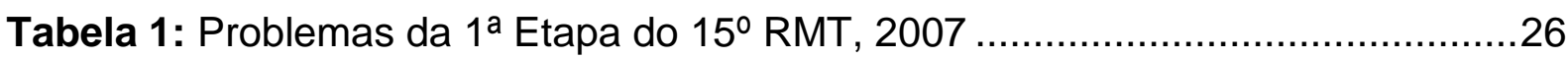

Tabela 2: Solução Problema 1, Prova I - Fase 1 - Etapa 2 ................................70

Tabela 3: Solução Problema 2, Prova I ........................................................ 74

Tabela 4: Resultado Questão 1, Atividade Inicial - Fase 1 - Etapa 1 ....................100

Tabela 5: Resultado Questão 2, Atividade Inicial - Fase 1 - Etapa 1 ..................101

Tabela 6: Resultado Prova I - Fase 1 - Etapa 2 ..........................................113

Tabela 7: Resultado Problema 2 - Fase 1 - Etapa 2 ....................................118

Tabela 8: Resultado Problema 3 - Fase 1 - Etapa 2 ...................................122

Tabela 9: Resultado Prova II - Fase 2 - Etapa 1 ............................................130

Tabela 10: Resultado Problema 2 - Fase 2 - Etapa 1 ....................................131

Tabela 11: Resultado Problema 3 - Fase 2 - Etapa 1 ................................... 134

Tabela 12: Resultado Prova III - Fase 3 - Etapa 1 ....................................... 140

Tabela 13: Resultado Problema 2 - Fase 3 - Etapa 1 ...................................143

Tabela 14: Resultado Prova III - Fase 3 - Etapa 1 ......................................148 


\section{Capítulo 1}

Introdução

\subsection{Considerações Preliminares}

A utilização da Resolução de Problemas (RP) como metodologia vem sendo destacada desde meados dos anos de 1980, no Brasil e no mundo, como um dos propósitos do ensino da Matemática. As orientações nos Parâmetros Curriculares Nacionais (BRASIL, 1998) enfatizam a Resolução de Problemas como alternativa para desenvolver a compreensão matemática nos alunos. Porém, reconhece-se que normalmente os problemas não desempenham, no ensino, o papel descrito, já que, geralmente, são empregados apenas como forma de aplicação de conhecimentos e procedimentos anteriormente adquiridos pelos alunos.

Nas pesquisas em relação ao tema, observa-se uma tendência em considerar que a Resolução de Problemas deve ir além no desenvolvimento da compreensão matemática: deve proporcionar a descoberta, dar oportunidade ao aluno de desenvolver diferentes tipos de raciocínio e estratégias, pensar matematicamente, ampliar seu conhecimento, de forma a dar sentido aos conceitos e propriedades matemáticas. Segundo Allevato (2005), a Resolução de Problemas favorece um trabalho mais autônomo, em que o conhecimento construído fará mais sentido para o aluno, aumentando a confiança em suas próprias capacidades.

O ensino baseado numa metodologia de Resolução de Problemas é favorável na construção de novas ideias. "Novas ideias são formadas pouco a pouco, ao longo do tempo, quando os alunos refletem ativamente sobre elas e as testam através dos muitos diferentes caminhos que o professor pode lhes oferecer" (ONUCHIC; ALLEVATO, 2004, p. 240).

Com isso, destacamos o que essas autoras consideram: o desenvolvimento de processos de pensamento de alto nível deve ser promovido através da experiência em Resolução de Problemas.

Proporcionar esse tipo de prática na sala de aula é a principal motivação para este trabalho. 
Um aspecto importante a ser considerado na atividade de Resolução de Problemas são as representações matemáticas. Conforme aponta Carreira (1999), os diferentes tipos de representações de ideias matemáticas são entendidos como ferramentas úteis na busca de soluções aos problemas propostos. A autora destaca a diferenciação entre representações internas, relacionadas às imagens mentais construídas por um indivíduo, e representações externas. No segundo caso, trata-se de organizações simbólicas materializáveis que têm por objetivo traduzir uma determinada situação. Dessa forma, considera representações matemáticas os objetos formais utilizados para construir representações externas que se enquadram num conjunto de estruturas matemáticas ou fazem apelo a um universo conceitual de natureza matemática.

Carreira (1999) enfatiza o uso de representações como ferramentas matemáticas que os alunos devem mobilizar corretamente perante uma situação concreta. Segundo ela, se o aluno estiver em condições de desenvolver códigos gráficos ou simbólicos que lhe permitam representar uma situação, ele terá mais poder matemático para lidar com um problema.

Ainda com relação às representações externas, Raymond Duval, filósofo e psicólogo francês, fornece um referencial estruturado de análise do funcionamento cognitivo do pensamento em Matemática, considerando mudanças de representação semiótica de objetos matemáticos. Primeiramente, Duval (2009) destaca que, em Matemática, os objetos não são acessíveis perceptiva ou instrumentalmente e 0 acesso a eles passa necessariamente por representações semióticas e não se deve confundir um objeto com sua representação. A partir daí, esse autor considera que a aquisição conceitual baseia-se na coordenação de diversos registros semióticos de representação. Para Duval (2013), como veremos mais adiante, existem diferentes tipos de registros: a língua natural - associações verbais com argumentações e deduções; o registro geométrico ou figural - figuras geométricas planas ou espaciais, com apreensão operatória e não somente perceptiva, além da construção com instrumentos de desenho; os sistemas de escrita e cálculo - numéricos, algébricos, simbólicos; e o registro gráfico - mudanças de sistema de coordenadas, interpolação e extrapolação. Do ponto de vista do ensino, possibilitar a apropriação desses diferentes registros implica em criar condições para a apreensão de conceitos matemáticos pelos alunos. 
Desta forma, entendemos ser válido considerar um estudo sobre o papel das representações nos processos de resolução de problemas.

Apesar dos estudos e do que se discute sobre a utilização da Resolução de Problemas, fazer com que a metodologia seja incorporada à sala de aula de forma efetiva, com os objetivos previstos, não é uma tarefa fácil para os professores. Ainda assim, as razões para que tal metodologia seja utilizada devem ser consideradas.

Para grande parte dos professores da Educação Básica, abordar conceitos e métodos sob a perspectiva da Resolução de Problemas ainda se limita a explicar um procedimento que funcione para resolver determinados tipos de problemas e fazer com que seu aluno reproduza essa técnica. Dessa forma, a resolução de um problema em Matemática se apresenta como algo "estático", restrito à identificação de uma técnica específica, não estimulando nem propiciando o desenvolvimento do pensamento matemático e da criatividade. Tal perspectiva contribui para que os alunos não compreendam o valor e não vejam sentido nos conceitos e métodos matemáticos ensinados na escola.

A forma de trabalho descrita no parágrafo anterior faz parte do cotidiano da maioria das salas de aula de Matemática e, nesse contexto, segundo Medeiros (1999), o problema se caracteriza como uma questão cuja resposta sempre poderá ser obtida e o professor a conhece antecipadamente. Assim, podemos observar que há uma "regra" determinada implicitamente que poderá fazer com que a criatividade dos alunos seja limitada, uma vez que eles podem ser levados a uma atitude de dependência e simples memorização de conceitos e estratégias.

As questões referentes à efetiva implementação da Resolução de Problemas, em sala de aula, têm relação com a formação dos professores. Muitas vezes, as limitações ocorrem, pois, estudantes de cursos de Licenciatura (em formação inicial) não recebem o embasamento necessário para estudar e discutir metodologias de ensino de Matemática diversificadas em suas aulas e no estágio supervisionado. Antes do início da atividade docente, dificilmente esses estudantes têm a oportunidade de vivenciar, na prática, experiências que as envolvam. Assim, percebemos a falta de preparo de muitos professores que estão hoje na sala de aula, devido à abordagem superficial no que se refere às metodologias de ensino durante sua formação.

Em fase de conclusão do curso de Licenciatura em Matemática e já atuante como professora do Ensino Fundamental, também me vi despreparada para levar à 
sala de aula o que havia estudado. Conhecia as metodologias de ensino, as principais justificativas e benefícios de se usar cada uma delas, mas não sabia como implementá-las na prática docente. Entre elas, a que me pareceu ter maior destaque foi a Resolução de Problemas, em particular pela quantidade de trabalhos de pesquisa existentes sobre esse tema. NO entanto, poucos mostram resultados práticos a partir do uso dessa metodologia, sendo menos frequentes pesquisas com experiências reais nas salas de aula dos anos finais da Educação Básica.

Com essa trajetória e sentindo a necessidade de me qualificar e ampliar meu conhecimento a respeito de práticas de ensino, veio o interesse pela proposta do Mestrado Profissional em Ensino de Matemática da Universidade de São Paulo. Como estudante do mestrado, tive a oportunidade de participar do projeto Ensino da Matemática na Escola Elementar, no âmbito do Observatório da Educação ${ }^{1}$ (OBEDUC), coordenado pela Profa. Dra. Cláudia Cueva Candido, cujo objetivo principal é contribuir para a melhoria do ensino na escola básica por meio do vínculo entre licenciandos e docentes do curso universitário e professores de Matemática de escola públicas.

Por meio do projeto, os professores participantes levam para o grupo questões relacionadas ao ensino e à aprendizagem de Matemática, com o intuito de buscar propostas, novas ideias e estratégias que minimizem os problemas de sala de aula, em particular os relacionados às dificuldades de aprendizagem dos alunos.

A partir dessa percepção e constatando, ainda, o desinteresse e as dificuldades que seus alunos enfrentam ao resolver problemas, uma professora participante do projeto se interessou em trabalhar e aprofundar seus conhecimentos a respeito do tema. Dessa forma, segundo esse interesse comum, optou-se por realizar uma experiência com base na Resolução de Problemas para as turmas dessa professora, na intenção de que os alunos pudessem ver a Matemática como algo com sentido, que proporcionasse a eles o desenvolvimento do raciocínio e de estratégias e que, além disso, os motivasse na busca por soluções de problemas diversificados e pelo conhecimento matemático.

\footnotetext{
1 Projeto CAPES n. 20698.
} 


\subsection{Objetivos}

Esse trabalho teve como foco um experimento baseado na Resolução de Problemas. Com isso, propôs-se desenvolver - realizar e analisar - uma experiência de Resolução de Problemas, com alunos da $1^{1}$ série do Ensino Médio de uma escola pública da cidade de São Paulo/SP, inspirada na competição internacional Rali Matemático. Pretendíamos, assim, fazer com que a Resolução de Problemas fosse levada de forma efetiva para a sala de aula, de maneira que os alunos fossem participantes ativos dos processos de resolução dos problemas propostos.

Além disso, reconhecendo a importância de se considerar as representações no processo de resolução de problemas, vimos a necessidade de inserir esse tema como ponto central das análises das soluções dadas pelos alunos.

Para tanto, nos fundamentamos na pesquisa de Fagnant e Vlassis (2013). Essas autoras destacam o papel das representações no processo de resolução de problemas. Elas realizaram testes com alunos que não tinham familiaridade com a produção e a utilização de representações para resolver problemas, buscando analisar:

1) O efeito da presença de dois tipos de representação esquemática (diagramas e desenhos esquemáticos) na resolução de problemas aritméticos;

2) Como os alunos reutilizam cada uma dessas representações esquemáticas na resolução de problemas;

3) Em que medida a presença e/ou a produção dessas representações esquemáticas têm impacto diferenciado de acordo com o tipo de problema.

Tal estudo examinou o impacto de dois tipos de representações esquemáticas (diagramas e desenhos esquemáticos) no desempenho dos alunos na resolução de problemas não-rotineiros. Os resultados iniciais mostraram que, sem instrução específica, os estudantes não fizeram uso espontâneo de qualquer representação esquemática para resolvê-los.

Em uma das fases do experimento, em que os problemas eram acompanhados por um dos tipos de representação sugerindo um meio de representá-los, verificou-se um efeito positivo no desempenho geral dos estudantes. 
$\mathrm{Na}$ última fase, em que os problemas do teste novamente não estavam acompanhados da sugestão de representação, a maioria dos alunos produziu ou tentou produzir uma representação semelhante às sugeridas anteriormente.

Quanto aos tipos de problemas propostos, diferenças no impacto dependem do tipo de problema e da categoria de esquema pré-definido. Diagramas tiveram efeito claramente positivo para todos os tipos de problemas, enquanto diagramas do tipo "matriz" (relacionados a tabelas de dupla entrada) não tiveram efeito em problemas de "combinação multiplicativa".

Em relação ao nosso experimento, os alunos resolveram problemas no contexto do que é proposto no Rali Matemático. Com essa escolha, fizemos a hipótese que o Rali fornece um ambiente favorável à aprendizagem matemática via Resolução de Problemas. Mais especificamente, as discussões de problemas do Rali permitiram um tipo de intervenção com ênfase nas representações, nos moldes da pesquisa citada acima.

O experimento também foi composto por três fases divididas em etapas. Em uma das etapas de cada fase, dentro do princípio de trabalho coletivo do Rali, os alunos trabalharam em grupos aos quais foram propostas provas elaboradas com problemas extraídos do banco de questões do Rali.

Todas as provas consistiam na resolução de dois problemas que envolvem conceitos do domínio das Funções e um do domínio da Geometria.

A importância de se incluir problemas de Geometria em todas as fases do experimento se justifica pelo fato de que a resolução desse tipo de problema exige um desenvolvimento de raciocínio diferenciado e, por isso, representações especiais.

As produções dos alunos obtidas em cada fase foi a principal fonte de dados da pesquisa. Para análise desses dados, a avaliação das resoluções dos alunos foi apoiada pela atribuição de pontos determinada nas análises a priori dos problemas, fornecida pelos organizadores da competição, no banco de problemas.

Após cada prova, foram realizadas intervenções com enfoque nas possíveis representações de cada problema. Apenas na segunda prova, os problemas foram adaptados de modo a indicar, para os alunos, a produção de determinadas representações. As fases desenvolvidas estão detalhadas no capítulo direcionado à metodologia. 
Assim, com esse estudo, buscamos responder a seguinte pergunta: em que medida o uso de determinados registros de representação subsidiam as atividades de resolução de problemas de alunos do Ensino Médio?

Para respondê-la, com a análise dos dados, a partir da realização da experiência, procuramos examinar os seguintes aspectos:

- Principais dificuldades dos alunos na resolução dos problemas propostos, relacionando-as a conhecimentos conceituais ou procedimentais;

- Tipos de representações com as quais os alunos estão mais familiarizados e as que produzem espontaneamente na resolução dos problemas;

- O papel das representações envolvidas nas resoluções, considerando um trabalho efetivo sobre elas;

- A reutilização das estratégias discutidas em cada fase do experimento.

\subsection{Organização do Trabalho}

O primeiro capítulo corresponde à Introdução e está dividido em três partes. $\mathrm{Na}$ primeira, temos as Considerações Preliminares, em que há uma apresentação da temática de estudo: Resolução de Problemas, relacionando-a com as representações matemáticas, além da motivação para se trabalhar com o tema, uma breve trajetória acadêmica e a maneira como o trabalho se insere na proposta do projeto OBEDUC. A segunda e terceira partes contêm, respectivamente, os objetivos e a estrutura do trabalho.

O capítulo 2 é destinado à apresentação do Rali Matemático. Nele temos a descrição completa da competição, seguida de histórico, dos tipos de prova e o formato ou características dos problemas propostos nas diferentes fases.

No capítulo 3, há uma revisão da literatura acerca da Resolução de Problemas no ensino da Matemática, buscando relacionar o Rali e seus problemas no contexto dos trabalhos já existentes. Além disso, no capítulo 4, são apresentados alguns constructos teóricos que serão usados tanto na elaboração da estratégia 
metodológica quanto na análise das produções dos alunos, principalmente sobre o papel das representações na Resolução de Problemas.

O capítulo seguinte descreve a metodologia da pesquisa. Nele serão incluídas as etapas da realização do experimento, bem como as estratégias e o material utilizado na implementação das atividades do Rali junto às turmas da escola participante do projeto.

O capítulo 6 traz a análise dos resultados da pesquisa.

A última parte é destinada às considerações finais. 


\section{Capítulo 2}

\section{O Rali Matemático Transalpino}

\subsection{Descrição do Rali Matemático}

O Rali Matemático Transalpino (RMT) é uma competição entre classes destinada a alunos de 8 a 15 anos, separados em categorias de acordo com a série escolar em que estão (categorias de 3 a 10). Atualmente, a disputa é promovida pela Associação Rali Matemático Transalpino (ARMT), que se enquadra nas seguintes determinações:

- Associação cultural que tem por objetivo promover a resolução de problemas para melhorar a aprendizagem e o ensino de Matemática por meio de um confronto entre classes/turmas;

- Sem fins lucrativos;

- As atividades podem se desenvolver em qualquer parte do mundo.

As tarefas de organização do Rali a cargo do comitê internacional da ARMT são:

- Elaboração das provas (que são as mesmas para todas as seções), e que compreendem:

- Os enunciados dos problemas e sua separação por categoria;

- Uma análise de conteúdos matemáticos e da tarefa do aluno em cada problema;

- Os critérios de atribuição de pontos;

- Às vezes, indicações para as análises a posteriori.

- Coletânea e análises estatísticas feitas por intermédio do site;

- Organização das análises a posteriori.

Em nível regional ou nacional, as tarefas de organização das seções se resumem à:

- Gestão das inscrições das classes, com elaboração das listas de turmas participantes por categoria; 
- Determinação do calendário de atividades (datas ou períodos de ocorrência das provas);

- Transmissão das provas às classes;

- Avaliação ou atribuição de pontos e classificações internas;

- Devolutiva dos resultados (via site) ao comitê internacional da ARMT;

- Organização da final regional;

- Interface com as classes:

- Informações;

- Cotas, certificados de participação, prêmios.

Entre os objetivos estabelecidos pela ARMT, podemos destacar o que é proposto aos alunos:

- Fazer matemática resolvendo problemas;

- Aprender regras elementares do debate científico, discutindo e defendendo as diversas soluções propostas;

- Desenvolver suas capacidades - cada vez mais essenciais no mundo de hoje - de trabalhar em grupo ou em equipe, assumindo coletivamente a responsabilidade da prova;

- Competir com outros colegas, com outras classes (de outras regiões e até de outros países).

Além disso, o Rali permite ao professor das turmas participantes:

- Observar os alunos na atividade de resolução de problemas quando ele participa da aplicação das provas;

- Avaliar a produção de seus próprios alunos e suas capacidades de organização, discussão de soluções e explorá-las depois em classe;

- Introduzir elementos inovadores em seu ensino por meio de trocas de informações com outros colegas e das contribuições com problemas estimulantes;

- Engajar-se nas equipes organizadoras e participar, assim, da preparação, discussão e escolha dos problemas, da correção em conjunto das provas e análise das soluções. 


\subsection{Histórico do Rali Matemático}

Com o nome de Rali Matemático Romande², a competição começou em 1993, com participação de 20 turmas de alunos de 8 a 11 anos ( $3^{\circ}$ a $6^{\circ}$ ano), separadas em categorias de acordo com a série. O Rali vem com o diferencial de se destinar às classes inteiras, quando a maioria das competições de Matemática, na época, era individual.

Nos anos que se seguiram, o número de participantes do Rali aumentou, tornando-o conhecido em outras regiões e países da Europa. Assim, para a quinta edição do Rali, a competição passou a se chamar Rali Matemático Transalpino (RMT), com a participação de classes das regiões de Parma e Pavia, na Itália. A partir daí, a equipe organizadora inicial foi ampliada e dividida em seções (ou sedes), de acordo com o país de origem das escolas e turmas participantes.

Com a abertura para outras cidades da Itália, bem como para cidades francesas, e a inclusão de turmas de $7^{\circ}$ ano, a partir de 1997, o número de inscritos aumentou ainda mais, alcançando 300 classes naquele ano. Diante da importância dada à resolução de problemas no ensino-aprendizagem de Matemática, e visando estudar as consequências do RMT dessa perspectiva, a partir de então, ocorreram encontros internacionais anuais, tendo como primeiro tema: Contribuições do RMT à Educação Matemática.

Em 1998, o RMT foi aberto para turmas de $8^{\circ}$ e $9^{\circ}$ ano, tendo, então, entre 500 e 600 classes participantes. O que foi chamado de "finais das finais", em que há a atribuição de pontos por um mesmo júri para todas as classes ganhadoras de finais regionais, passou a ocorrer todos os anos a partir dali.

Ao longo dos anos, questões sobre objetivos das provas, critérios de correção com definição de pontos, exploração dos problemas, contribuições para a aprendizagem dos alunos e para a formação de professores, foram sendo discutidas nos encontros internacionais anuais. Em 2005, foram criados grupos de estudo permanentes - denominados Grupos de Trabalho - para exploração didática dos problemas, com temas como construção de conceitos de proporcionalidade, ângulos,

\footnotetext{
${ }^{2}$ Em referência à região francófona da Suíça, também chamada de Suíça francesa. Cerca de 1,5 milhões de pessoas ( $20 \%$ da população suíça) vive nessa região, de onde é o idealizador do Rali, Prof. François Jacquet.
} 
numeração, equações, funções, áreas e combinatória. Naquele ano, foram 21 seções, com mais de 2000 classes inscritas.

Em 2010 foi lançada a Gazeta Transalpina, uma revista on-line publicada no site da $\mathrm{ARMT}^{3}$, destinada a organizadores, participantes e interessados pelo ensino e aprendizagem da Matemática por meio da Resolução de Problemas. Esta revista visa apresentar o RMT a um público maior, para comunicar o interesse pela resolução de problemas e publicar, em particular, artigos com resultados dos grupos de trabalho.

Em 2014, o RMT chegou a sua 22 ${ }^{a}$ edição, com 25 seções de 7 países ${ }^{4}$ e mais de 4000 classes inscritas. O encontro internacional teve como tema Problemas do RMT e formação de professores.

\subsection{As provas do Rali}

As provas do RMT devem ocorrer a partir de um "contrato" entre a equipe organizadora, professores e alunos. A decisão de participação deve ser tomada em conjunto pela classe e o professor, após uma prova teste.

Aceita a proposta de participação pelos alunos e pelo professor, em comum acordo, são realizadas duas etapas e, por fim, uma final, em que as provas são elaboradas em cooperação entre diferentes equipes, regionais e nacionais, e as traduções (em francês, italiano, alemão, espanhol e árabe) são rigorosamente comparadas.

A prova teste tem o mesmo formato das provas que compõem as duas etapas da competição - denominadas Prova I e Prova II - bem como a prova final: 5 a 7 questões em cada prova, dependendo da categoria: as provas das categorias 3, $4 \mathrm{e}$ 5 são compostas de 5 questões e as demais categorias ( 6 a 10) conta com 7 questões, sendo que algumas podem ser comuns a várias categorias.

Antes do início de cada etapa, o professor deve considerar uma preparação, preocupando-se com que os alunos possam trabalhar no melhor ambiente possível e que eles disponham de todo o material que possa ser necessário na resolução das

\footnotetext{
${ }^{3}$ http://www.armtint.org/

${ }^{4}$ São eles: Argélia, Argentina, Bélgica, França, Itália, Luxemburgo, Suíça.
} 
provas, tais como: tesoura, cola, régua, cubinhos ou fichas, compasso, papel, lápis, calculadora, etc. Telefones celulares e computadores com acesso à Internet não são permitidos durante as provas.

Enquanto na prova teste o professor de Matemática participa como observador, as etapas seguintes devem ocorrer sem a presença do professor de Matemática da turma. É necessário que ele seja substituído por um colega que, de preferência, não seja da área. Com isso, pretende-se evitar questionamentos dos alunos durante a prova, reforçando que eles devem resolver os problemas sem qualquer interferência do professor. O papel do professor aplicador limita-se a distribuir as folhas de questões, controlar o tempo, recolher as folhas de respostas e transmiti-las ao professor da turma para que este as encaminhe à equipe de correção.

Em cada uma das provas, a resolução dos problemas é proposta para a classe toda. Em até 50 minutos, a turma deve entregar uma única folha-resposta para cada problema que contenha a(s) solução(ões) com todas as explicações e justificativas de como se chegou a elas. $\mathrm{Na}$ tentativa de envolver todos os alunos, os problemas são escolhidos de modo a serem acessíveis a cada um deles, mas com um nível de dificuldade que não permite que sejam resolvidos por apenas um indivíduo no tempo determinado. Assim, segundo recomendações da ARMT, deve-se lembrar aos alunos que eles contarão apenas com eles mesmos na organização e divisão do trabalho.

Como previsto, o professor é responsável, após cada etapa, por encaminhar as folhas-resposta para a equipe avaliadora. Recomenda-se, no entanto, que ele explore, discuta, refaça e analise os resultados dos problemas em conjunto com os alunos.

A análise a priori das questões elaboradas permite a determinação dos critérios que serão levados em consideração na correção das respostas. Para cada questão é atribuído um número de pontos que varia de 0 a 4 por uma banca da seção, composta de 2 a 3 professores. É importante lembrar que, caso várias folhas de resposta forem entregues para um mesmo problema, a atribuição será de "0" ponto e as soluções não são avaliadas. Os pontos obtidos em cada etapa são somados. Dessa forma, as soluções são julgadas pelo rigor na maneira de conduzir o raciocínio e pela clareza nas explicações, e não apenas pelos resultados obtidos. Após as correções, é estabelecida, a partir das duas primeiras etapas, uma classificação por região e por categoria, o que define a participação das turmas nas finais: as classes com os 
melhores resultados nas Provas I e II. Geralmente entre 10\% e 20\% das turmas participantes em cada categoria seguem para as finais.

O anúncio dos resultados fica a cargo das seções, que os disponibilizam no site da ARMT. As análises mais detalhadas são publicadas em boletins e artigos na Gazeta Transalpina.

\subsection{Os Problemas do Rali}

Os problemas das provas do Rali são diferenciados pelo(s) domínio(s) matemático(s) necessário(s) para sua resolução e pela categoria às quais se destinam. Os referidos domínios considerados são: Aritmética, Álgebra, Geometria e Lógica. Na Tabela 1, temos um exemplo dessa diferenciação: trata-se dos problemas da primeira etapa da 15ª edição do Rali Matemático, que ocorreu em 2007.

As categorias (3 a 10) correspondem aos seguintes anos de escolaridade: a categoria 3 corresponde à $3^{a}$ série primária (na Bélgica ou CE2 na França), no Brasil, $3^{\circ}$ ano do Ensino Fundamental (alunos de 8 anos de idade, ou último ano do ciclo de alfabetização); a categoria 4 corresponde à $4^{\text {a }}$ série primaria (ou CM1 na França), $4^{\circ}$ ano no Brasil, e assim por diante.

A análise a priori dos problemas tem como objetivo explicitar quais são os conteúdos matemáticos a serem utilizados na resolução do problema, indicar a tarefa do aluno e os critérios de atribuição de pontos. A título de ilustração, a seguir (Quadro 1), vemos um dos problemas listados na Tabela 1 acompanhado de sua análise a priori. Em seguida, apresentamos, no Quadro 2, um dos problemas da prova final do RMT de 2005. 


\begin{tabular}{|c|c|c|c|c|c|c|c|c|c|c|c|c|c|}
\hline $\mathbf{N}^{\circ}$ & Título & & & & Cate & egol & & & & Domí & ios M & atemá & icos \\
\hline & & 3 & 4 & 5 & 6 & 7 & 8 & 9 & 10 & Arit. & Alg. & Geo. & Log. \\
\hline 1. & O burro de Tom & 3 & & & & & & & & $x$ & & & \\
\hline 2. & Número a adivinhar & 3 & 4 & & & & & & & $x$ & & & \\
\hline 3. & Quem é o mais velho? & 3 & 4 & & & & & & & & & & $x$ \\
\hline 4. & A vaca no pomar & 3 & 4 & & & & & & & & & $x$ & \\
\hline 5. & As idades das irmãs & 3 & 4 & 5 & & & & & & $x$ & & & $x$ \\
\hline 6. & O ciclista & & 4 & 5 & 6 & & & & & $x$ & & & \\
\hline 7. & Jantar de gala & & 4 & 5 & 6 & & & & & $x$ & & & $\mathrm{X}$ \\
\hline 8. & O quadrado de Tomás & & & 5 & 6 & & & & & & & $x$ & $x$ \\
\hline 9. & Jogos de golfe & & & 5 & 6 & & & & & $x$ & & & $x$ \\
\hline 10. & Corta e recorta & & & 5 & 6 & 7 & & & & & & $x$ & \\
\hline 11. & Os bancos do parque & & & 5 & 6 & 7 & & & & $x$ & & & \\
\hline 12. & A mesa de jardim & & & & 6 & 7 & & & & $x$ & & $x$ & \\
\hline 13. & História de cubos & & & & & 7 & 8 & & & $x$ & & $x$ & \\
\hline 14. & O pinheiro & & & & & 7 & 8 & & & $x$ & & $x$ & \\
\hline 15. & $\begin{array}{l}\text { Solidariedade para a } \\
\text { África }\end{array}$ & & & & & 7 & 8 & 9 & & $\mathrm{x}$ & $\mathrm{x}$ & $x$ & \\
\hline 16. & A maratona transalpina & & & & & 7 & 8 & 9 & 10 & $x$ & $x$ & & $x$ \\
\hline 17. & A noite da excursão & & & & & 7 & 8 & 9 & 10 & $x$ & & & \\
\hline 18. & O relógio digital & & & & & & 8 & 9 & 10 & & & $x$ & \\
\hline 19. & $\begin{array}{l}\text { O quebra-cabeça } \\
\text { retangular }\end{array}$ & & & & & & 8 & 9 & 10 & & & $x$ & \\
\hline 20. & Uma adição estranha & & & & & & & 9 & 10 & $x$ & & & $x$ \\
\hline 21. & Um cubo com janelas & & & & & & & 9 & 10 & & & $x$ & \\
\hline 22. & Um foguete muito rápido & & & & & & & & 10 & $x$ & & & \\
\hline
\end{tabular}

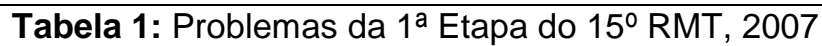

Fonte: http://www.armtint.org/

$\mathrm{Na}$ análise a priori do problema A Noite de Excursão, vemos as diferentes maneiras de se chegar à resposta, que podem ser discutidas com os alunos, e que sua resolução envolve o domínio da Aritmética. O problema dos Quadritriângulos requer, além de conhecimentos sobre as operações matemáticas, conhecimentos de conceitos da Geometria. 
17. A NOITE DE EXCURSÃO (Cat. 7, 8, 9, 10)

As classes do instituto "Arquimedes" vão em excursão a Nápoles. Elas chegam ao hotel "Vesúvio", onde os alunos passarão a noite. $O$ hotel coloca à disposição três quartos com 5 camas, quatro quartos com 4 camas e oito quartos com 3 camas. Todas as camas serão ocupadas.

A classe A é composta por 20 alunos, sendo 7 meninos; a classe B tem 18 alunos, sendo 8 meninos, enquanto há apenas 6 meninos na classe $C$.

É possível alojar os alunos nos quartos colocados à disposição pelo hotel de maneira que, em cada quarto, haja apenas meninos da mesma classe ou meninas na mesma classe?

Como os alunos podem ser divididos nos quartos?

Expliquem seu raciocínio.

\section{ANÁLISE A PRIORI}

Domínio de conhecimento

- Aritmética: adição, multiplicação, decomposição de números.

\section{Análise da tarefa}

- Compreender que deve haver 55 alunos, de acordo com o número de todos os leitos ocupados $(3 \times 5+4 \times 4+8 \times 3)$ e que, por consequência, existem 11 meninas na classe $C$ $(55-20-18-6)$.

- Compreender que a distribuição de certos grupos de alunos nos quartos é impossível: os 7 meninos da classe A ocuparão um quarto triplo e um quarto quádruplo; os 6 meninos da classe $\mathrm{C}$ ocuparão dois quartos triplos.

- Distribuir os quartos ainda disponíveis (três quartos de 5 camas, três quartos de 4 camas, cinco quartos de 3 camas) entre os alunos que restam, decompondo os efetivos desses quatro grupos ( 8 meninos de $B, 13$ meninas de A, 10 meninas de $B$ e 11 meninas de $C$ ) em somas de números 3 , 4 e 5 :

$$
\begin{aligned}
& 8=4+4 \quad \text { ou } \quad 8=5+3 \\
& 13=3+3+3+4 \quad \text { ou } \quad 13=5+4+4 \quad \text { ou } \quad 13=5+5+3 \\
& 10=5+5 \quad \text { ou } 10=3+3+4 \\
& 11=3+3+5 \quad \text { ou } \quad 11=3+4+4
\end{aligned}
$$

- Pode-se proceder de diferentes maneiras para organizar o inventário de possibilidades, por exemplo, por meio de diagramas de árvore ou de outras representações gráficas, mas sempre de maneira sistemática. Restam 5 combinações possíveis após as eliminações:

$$
\begin{array}{llll}
8=4+4 & 13=3+3+3+4 & 10=5+5 & 11=3+3+5 \\
8=5+3 & 13=3+3+3+4 & 10=5+5 & 11=3+4+4 \\
8=4+4 & 13=5+5+3 & 10=3+3+4 & 11=3+3+5 \\
8=5+3 & 13=5+5+3 & 10=3+3+4 & 11=3+4+4 \\
8=5+3 & 13=4+4+5 & 10=3+3+4 & 11=3+3+5
\end{array}
$$

Quadro 1: Problema 17 da Prova I do $15^{\circ}$ RMT, 2007

Fonte: http://www.armtint.org/, tradução nossa. 
11. Quadritriângulos (Cat. 6, 7, 8, 9)

Com quatro triângulos retângulos iguais, de lados $3 \mathrm{~cm}, 4 \mathrm{~cm} \mathrm{e} 5 \mathrm{~cm}$, dispostos de maneira que cada triângulo tenha ao menos um lado em comum com outro triângulo, pode-se obter diferentes figuras que chamaremos de "quadritriângulos".

Dois quadritriângulos são diferentes se eles têm ao menos um lado ou um ângulo diferente (não se leva em conta a disposição dos triângulos no interior). Por exemplo, esses dois quadritriângulos, de $22 \mathrm{~cm}$ de perímetro, não são considerados diferentes.
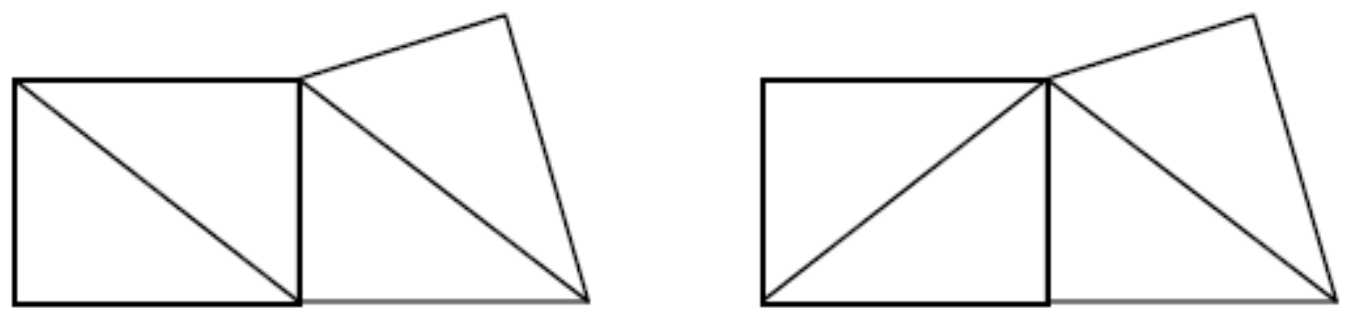

Entre todos os quadritriângulos, quais são aqueles que têm o menor perímetro?

Desenhe-os e explique como você os encontrou.

\section{ANÁLISE A PRIORI}

Domínio de conhecimento

- Aritmética: adição, subtração, multiplicação.

- Geometria: polígonos, equivalência, perímetro.

\section{Análise da tarefa}

- Ler o enunciado e compreender as regras de formação das figuras.

- Considerar que, se não tivessem lados em comum, o perímetro do quadrilátero seria $4 \times 12=$ 48. Deve-se, então, subtrair duas vezes a medida de cada lado em comum.

- Observar que não se pode ter 3 ou 4 lados comuns. No primeiro caso, para obter o perímetro mínimo, deve-se ter dois pares de lados de 5 e um par de lados de 4 em comum. No segundo caso, dois pares de lados de 3 e dois pares de lados de 4.

- Construir os quadritriângulos com os lados comuns assim determinados. Observar que há sempre duas maneiras de dispor dois triângulos, uma vez que seu lado comum foi escolhido. Por exemplo, para dois triângulos com a hipotenusa em comum, a disposição faz aparecer uma simetria axial ou uma simetria central, como mostram as figuras a e b seguintes.

- Podemos também proceder de maneira empírica, cortando os triângulos e recompondo as figuras.

Obtemos assim as 5 possibilidades $\mathrm{c}, \mathrm{d}, \mathrm{e}, \mathrm{f}, \mathrm{g}$, todas com um perímetro de $20 \mathrm{~cm}(48-28)$.
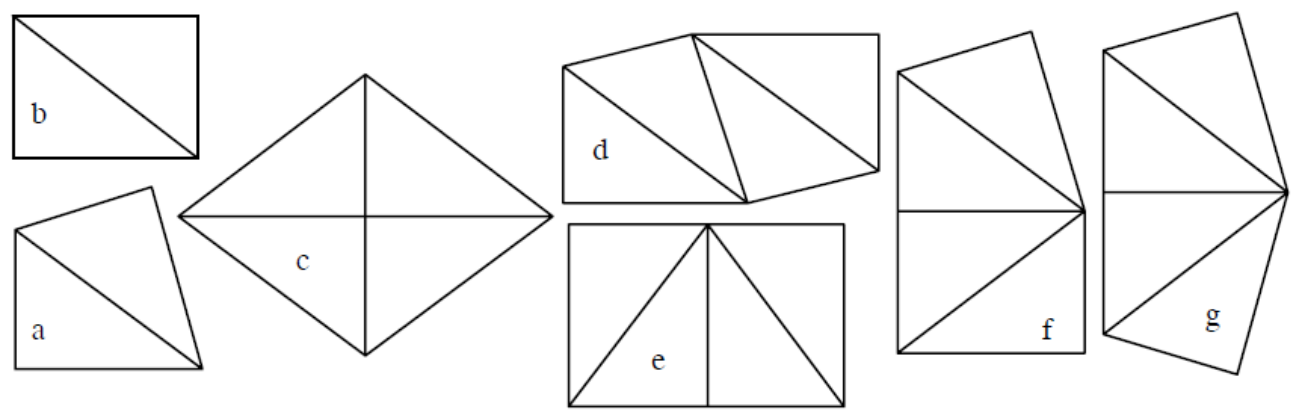

Quadro 2: Problema 11 da final do $13^{\circ}$ RMT, 2005

Fonte: http://www.armtint.org/, tradução nossa. 
As análises a posteriori, realizadas após as correções, permitem identificar os procedimentos adotados pelos alunos durante a resolução, as principais dificuldades ou obstáculos, os erros recorrentes, o nível de construção dos conceitos matemáticos dos alunos. O conjunto das análises dos dados coletados facilita a elaboração futura de problemas e permite conhecer mais sobre a maneira como os alunos os resolvem.

Todos os problemas são reagrupados num banco de problemas, em preparação atualmente, de acordo com as chamadas "famílias de tarefas", onde são identificados os conceitos matemáticos envolvidos e um sistema de palavras-chave para orientação. Nele são encontrados enunciados dos problemas, conceitos matemáticos envolvidos na resolução, os dados estatísticos da atribuição de pontos e, quando as análises a posteriori foram conduzidas, a descrição dos procedimentos observados efetivamente, as dificuldades e erros significativos revelados e também algumas ideias de exploração didática dos problemas para professores que queiram inseri-los no percurso de aprendizagem de suas classes. Quando ainda não há a análise a posteriori, as fichas do banco de problemas apresentam apenas as análises a priori. 


\title{
Capítulo 3
}

\section{Resolução de Problemas em Educação Matemática}

\subsection{Resolução de Problemas como metodologia}

Conforme já mencionado, as discussões acerca da Resolução de Problemas em Matemática começaram a ganhar espaço em meados dos anos 80 .

Segundo Onuchic e Allevato (2004), no início do século XX, o ensino da Matemática era baseado numa atividade de repetição, na qual o recurso à memorização de fatos básicos era considerado importante. Anos mais tarde, passouse a determinar que os alunos deveriam aprender com compreensão, entender os procedimentos que vinham sendo repetidos. Em nenhum dos casos houve sucesso completo, pois, a maioria dos alunos não aprendia.

Nas décadas de 1960 e 1970, apesar de já se falar de ensino de Matemática por meio da Resolução de Problemas, o movimento de renovação, conhecido como Matemática Moderna, "provocou mudanças significativas nas práticas escolares" (PINTO, 2005, p. 2).

Conforme destaca Pinto (2005), essa reforma apresentava a Matemática com excesso de simbolismos e enfatizava a necessidade de uma nova linguagem. Com isso, professores e alunos passaram a conviver com a teoria dos conjuntos e com as noções de estrutura e de grupo.

\begin{abstract}
Ao tratar a matemática como algo neutro, destituída de história, desligada de seus processos de produção, sem nenhuma relação com o social e o político, o ensino da Matemática, nesse período parece ter se descuidado da possibilidade crítica e criativa dos aprendizes. O moderno dessa matemática apresenta-se, para os alunos, mais como um conjunto de novos dispositivos e nomenclaturas descolados de sentidos e significados conceituais, uma disciplina abstrata e desligada da realidade (PINTO, 2005, p. 5).
\end{abstract}

Em reação à maneira como a Educação Matemática vinha sendo caracterizada, no início da década de 70 começaram as primeiras investigações sobre a Resolução de Problemas no ensino. "No fim dos anos 70, a Resolução de Problemas emerge, ganhando espaço no mundo inteiro" (ONUCHIC; ALLEVATO, 2004, p. 234). 
Nesse cenário, podemos destacar duas publicações do National Council of Teachers of Mathematics (NCTM) ${ }^{5}$ que tiveram grande significado para o desenvolvimento curricular e investigação em Resolução de Problemas nos Estados Unidos, segundo Lester (1994):

- An agenda for action (1980): documento cujo objetivo era sugerir direções para o desenvolvimento curricular e dar ênfase ao ensino na década de 80 . Foi responsável por esse período ter sido chamado de "a década da resolução de problemas", já que tinha esse tema como foco, mas em forma de guia para educadores matemáticos;

- Curriculum and Evaluation Standards for School Mathematics (1989): desenvolvidas como documento de ação de política educativa, destinava-se a construir uma proposta de política nacional para a Educação Matemática. Além de descrever a Matemática que todos os alunos devem conhecer e ser capaz de fazer, contém várias sugestões sobre como tornar a Resolução de Problemas o foco da Matemática escolar.

Conforme destacam Onuchic e Allevato (2004), a partir do final da década de 80, o NCTM buscou uma nova reforma para a Educação Matemática. Assim, ainda publicaram:

- Os Professional Standards for Teaching Mathematics (1991): que mostram possíveis caminhos a serem percorridos pelos professores a fim de estruturar as atividades de sala de aula para que os alunos aprendam a Matemática descrita nas Normas;

- Os Assessment Standards for School Mathematics (1995): que contêm os princípios para que os professores e educadores se apoiem na construção de avaliações que ajudem no desenvolvimento de uma Matemática forte para todos.

A partir desses Standards, surgiu uma nova geração de currículos que tinham como principal característica a utilização da Resolução de Problemas como um meio de desenvolver os conteúdos matemáticos e fazer conexões com outras áreas.

\footnotetext{
${ }^{5}$ Conselho Nacional de Professores de Matemática. Organização profissional sem fins lucrativos. Conta com mais de 125000 associados e é a principal organização para professores de Matemática (ONUCHIC; ALLEVATO, 2004, p. 235)
} 
Conforme as autoras citadas acima destacam, em meio a diversas críticas, após uma década de aplicação das ideias que estavam sendo defendidas, o NCTM lançou os Principles and Standards for School Mathematics (2000).

Conhecida como Standards 2000, a publicação apresenta seis Princípios a serem seguidos no ensino da Matemática: Equidade; Currículo; Ensino; Aprendizagem; Avaliação; e Tecnologia. Apresenta os Padrões de Conteúdo: Números e Operações; Álgebra; Geometria; Medida; Análise de Dados e Probabilidade. E, ainda, os Padrões de Processo: Resolução de Problemas, Raciocínio e Prova; Comunicação; Conexões e Representação.

Em relação ao Padrão de Resolução de Problemas, as orientações são de que programas institucionais devem tornar todos os estudantes aptos a:

- Construir um novo conhecimento matemático através da Resolução de Problemas;

- Resolver problemas que surgem em Matemática e em outros contextos;

- Aplicar e adaptar uma variedade de estratégias para resolver problemas;

- Monitorar e refletir sobre os processos de resolução de problemas matemáticos.

Onuchic e Allevato (2004) observam que a formulação dos PCN (1997, 1998,1999), no Brasil, esteve apoiada em ideias dos Standards. Portanto, percebemos nesses documentos uma grande preocupação em inserir a Resolução de Problemas no ensino de Matemática.

No que se refere ao tema, a recomendação dos $\mathrm{PCN}+$ - Ensino Médio e as Orientações Educacionais Complementares aos Parâmetros Curriculares Nacionais é a de que a Resolução de Problemas seja "peça central para o ensino da Matemática, pois o pensar e o fazer se mobilizam e se desenvolvem quando o indivíduo está engajado ativamente no enfrentamento de desafios" (BRASIL, 2002, p. 112). Segundo o documento, a competência necessária nesse tipo de atividade não se desenvolve quando se propõe apenas exercícios de aplicação dos conceitos e técnicas matemáticos.

Por isso, nos PCN+, encontramos indicações de que a Resolução de Problemas deve fazer parte do cotidiano escolar, uma vez que: oportunidade de pensar por si mesmo, construir estratégias de resolução e 
argumentações, relacionar diferentes conhecimentos e, enfim, perseverar na busca da solução. (BRASIL, 2002, p. 113).

Da mesma forma, nas Orientações Curriculares para o Ensino Médio (BRASIL, 2006), evidencia-se uma concepção de ensino na qual cabe ao aluno a construção do conhecimento matemático a partir da proposta de uma situação problema. Nesta perspectiva, a aprendizagem se realiza no momento em que o aluno, ao confrontar suas ideias, constrói os conceitos pretendidos pelo professor.

Diversos autores concordam que a Resolução de Problemas tem papel relevante no ensino de Matemática. No entanto, é preciso salientar as diferentes interpretações dadas ao tema. Mendonça (1999) considera três maneiras de pensar a Resolução de Problemas:

1) Como um objetivo, ou seja, para resolver problemas. Por esse ponto de vista, parece ser suficiente expor a teoria e, em seguida, propor problemas mais ou menos engenhosos;

2) Como um processo e, assim, olhar para o desempenho/transformação dos alunos como resolvedores. Desse modo, eles são levados a enfrentar problemas e desenvolver seu potencial heurístico. Em sala de aula procura-se trabalhar estratégias de solução.

3) Como um ponto de partida. O problema é adotado como recurso pedagógico, apresentado no início do processo de aprendizagem do que se espera atingir. Nesse contexto, o problema é destinado à construção de conhecimentos matemáticos.

Em Schroeder e Lester ${ }^{6}$ (1989 apud Onuchic; Allevato, 2004) vemos outras três maneiras de se abordar a Resolução de Problemas:

1) Teorizar sobre Resolução de Problemas;

2) Ensinar Matemática para resolver problemas;

3) Ensinar Matemática através da Resolução de Problemas.

Ao nos referirmos ao ensino sobre a Resolução de Problemas, podemos considerar os trabalhos de George Polya. O livro de Polya - How to Solve it, lançado em 1945 - "pode ser considerado, talvez, o mais importante exemplo entre trabalhos

\footnotetext{
${ }^{6}$ SCHROEDER, T. L.; LESTER Jr., F. K. Developing Understanding in Mathematics via Problem Solving. In: TRAFTON, P. R.; SHULTE, A. P. (Eds.). New Directions for Elementary School Mathematics. Reston: NCTM, p. 31-42, 1989.
} 
com teor essencialmente voltado a ensinar sobre resolução de problemas" (ALLEVATO, 2005, p. 49).

$\mathrm{Na}$ obra, o autor se dedicou a desenvolver orientações para a utilização de problemas em sala de aula. Dentro dessas orientações, coloca quatro etapas a serem seguidas: compreender o problema, estabelecer um plano, executar o plano e examinar a solução obtida.

De acordo com o que destacam Echeverría e Pozo (1998), Polya considerou procedimentos estratégicos (ou heurísticos) e outros procedimentos de resolução de problemas (regras, algoritmos ou operadores). Os primeiros guiam a Resolução de Problemas de forma mais vaga e global, enquanto os outros se constituem em conhecimentos adquiridos que permitem transformar a informação de uma maneira fixa, eficaz e concreta.

No segundo tipo de abordagem - ensinar para resolver problemas - Allevato (2005) comenta que se trata de uma visão utilitária da Matemática. Nesse caso, o professor se concentra em ensinar Matemática para aplicar na resolução de problemas. Ou seja, os alunos devem transferir o que aprenderam num contexto para problemas em outros contextos.

Van de Walle (2009) denomina esse tipo de abordagem como paradigma "ensinar-então-praticar", no qual o professor ensina a Matemática, depois disso os alunos a praticam por um tempo e, então, espera-se que eles possam usar as novas habilidades para resolver outros problemas. Nesse contexto, o aluno espera que o professor forneça uma regra que possa ser reproduzida. Para o autor, essa forma de ensino raramente funciona bem por duas razões.

A primeira está ligada ao fato de esse tipo de abordagem considerar que todos os alunos possuem, naquele momento, todas as ideias necessárias para dar significado à explicação do professor. Trata-se de uma abordagem expositiva que depende da absorção passiva de ideias. Apesar de ser eficaz para alguns estudantes, leva a maioria deles "a acreditar que a matemática é misteriosa e que está além de sua compreensão" (VAN DE WALLE, 2009, p. 58).

A segunda dificuldade mencionada pelo autor é que, com esse paradigma, a Resolução de Problemas fica separada do processo de aprendizagem. Para ele, tal separação também distancia o ensino do confronto com as ideias e, portanto, a aprendizagem de Matemática se separa do fazer Matemática. 
Com todas as diferenças entre cada tipo de abordagem, Onuchic e Allevato (2004) revelam a importância de reconhecer que o ensino de Matemática deve ser desenvolvido através da Resolução de Problemas. Dessa forma, tarefas envolvendo problemas ou atividades se tornam o veículo pelo qual um currículo deve ser desenvolvido. "A aprendizagem será uma consequência do processo de Resolução de Problemas" (ONUCHIC; ALLEVATO, 2004, p. 241).

Sob essa perspectiva, o ensino-aprendizagem de determinado conteúdo matemático sempre se iniciará com uma situação-problema. Assim, ao longo do processo de resolução, tópicos e técnicas matemáticos serão desenvolvidos, partindose do concreto para o abstrato.

Van de Walle (2009) lista algumas características de problemas voltados para a aprendizagem:

- O problema deve começar onde os alunos estão: a proposta deve considerar a compreensão atual dos alunos, de modo que eles tenham ideias apropriadas para se envolver e resolver o problema, além de considerá-lo desafiante e interessante.

- O aspecto problemático ou envolvente do problema deve estar relacionado à Matemática que os alunos irão aprender: os alunos devem estar preocupados em dar significado à Matemática envolvida e, assim, desenvolver sua compreensão sobre essas ideias.

- A aprendizagem matemática deve requerer justificativas e explicações para as respostas e os métodos. Com isso, os estudantes compreendem que eles também são responsáveis por determinar se suas respostas estão corretas e o porquê de estarem corretas.

Assim, segundo o autor, as tarefas ou atividades propostas para envolver os alunos devem ser fundamentadas em problemas e em um pensamento ativo. $O$ ensino através da Resolução de Problemas é um processo centrado mais no aluno - no seu conhecimento prévio, isto é, a partir das concepções que os alunos já possuem - do que no professor e, portanto, requer confiança nas ideias significativas que o aluno pode criar.

Para Allevato e Onuchic (2009), não há uma maneira determinada para a implementação da metodologia de Resolução de Problemas. No entanto, as autoras propõem uma forma de organizar as atividades segundo as seguintes etapas: 
1) Preparação do problema: selecionar um problema, que será considerado gerador, visando à construção de um novo conceito, princípio ou procedimento.

2) Leitura individual: entregar uma cópia do problema para cada aluno e solicitar que seja feita a leitura.

3) Leitura em conjunto: formar grupos e solicitar nova leitura do problema, agora nos grupos.

4) Resolução do problema: os alunos, em seus grupos, num trabalho cooperativo e colaborativo, buscam resolver o problema.

5) Observar e incentivar: durante a resolução dos problemas pelos alunos 0 professor deve observar, analisar o comportamento dos alunos nos grupos e estimular o trabalho colaborativo. Ele tem o papel de mediador e leva os alunos a pensar, dandoIhes tempo e incentivando a troca de ideias entre eles.

6) Registro das resoluções na lousa: representantes dos grupos são convidados a registrar, na lousa, suas resoluções. Resoluções certas, erradas ou feitas por diferentes processos devem ser apresentadas para que todos os alunos as analisem e discutam suas diversas interpretações.

7) Plenária: discussão sobre as diferentes resoluções registradas na lousa pelos colegas. Os alunos devem ser guiados pelo professor a defenderem seus pontos de vista e esclarecerem suas dúvidas.

8) Busca do consenso: sanadas as dúvidas e analisadas as resoluções e soluções obtidas para o problema, o professor tenta, com toda a classe, chegar a um consenso sobre o resultado correto.

9) Formalização do conteúdo: o professor registra na lousa uma apresentação "formal" - organizada e estruturada em linguagem matemática - padronizando os conceitos, os princípios e os procedimentos construídos através da resolução do problema, destacando as diferentes técnicas operatórias e as demonstrações das propriedades qualificadas sobre 0 assunto.

Van de Walle (2009) também apresenta uma maneira de se encaminhar as aulas fundamentadas na Resolução de Problemas, sugerindo três fases: antes, durante e depois.

A fase antes é o momento de preparação dos alunos, que requer os seguintes procedimentos:

- Verificar se o problema foi compreendido;

- Ativar os conhecimentos prévios úteis; 
- Estabelecer expectativas claras.

Durante é quando os alunos estão trabalhando e o professor deve:

- Deixar os alunos construírem seus conhecimentos, evitando antecipações desnecessárias;

- Escutar cuidadosamente;

- Fornecer sugestões adequadas;

- Observar e avaliar.

$\mathrm{Na}$ fase depois, os alunos irão debater as soluções encontradas e o professor deve:

- Encorajá-los na partilha de suas ideias;

- Escutar/aceitar as soluções sem julgá-las;

- Sintetizar as principais ideias e identificar futuros problemas.

Onuchic e Allevato (2004) consideram que a compreensão da Matemática por parte dos alunos envolve a capacidade que eles têm de relacionar problemas e ideias matemáticas. Assim, as autoras compreendem que as indicações de que um estudante entende, interpreta mal ou não entende ideias matemáticas específicas surgem, com frequência, quando ele resolve um problema. Portanto, para as autoras, a metodologia de Resolução de Problemas tem como foco central e objetivo principal a compreensão da Matemática. Com isso, o papel da Resolução de Problemas no currículo é ampliado, tornando-se um meio de adquirir novos conhecimentos.

Assim, conforme enfatiza Van de Walle (2009), apesar de não ser uma tarefa fácil, há boas razões para que professores insistam no esforço de ensinar através de Resolução de Problemas, entre elas:

- A Resolução de Problemas concentra a atenção dos alunos sobre as ideias e em dar sentido a elas;

- A Resolução de Problemas desenvolve nos alunos a convicção de que eles são capazes de fazer Matemática e de que a Matemática faz sentido;

- A Resolução de Problemas possibilita um ponto de partida para grande parte dos alunos;

- A Resolução de Problemas desenvolve o "potencial matemático".

Além disso, o autor considera que o ensino baseado na Resolução de Problemas pode ser, ainda, interessante para os professores pelo estímulo de 
desenvolver a compreensão dos alunos através do raciocínio deles mesmos. O que também pode ser divertido para os próprios alunos.

Há vasta bibliografia sobre o tema, com perspectivas próximas à dos autores citados acima. Cabe salientar que ao usarmos o termo "problema" é preciso ter claro seu significado. No âmbito do nosso estudo, é preciso, ainda, verificar de que forma os problemas do Rali se relacionam com as diferentes definições ou caracterizações encontradas na literatura. É o que passamos a discutir na sequência.

\subsection{Resolução de Problemas no Rali Matemático}

Referindo-se à Resolução de Problema como via para que o aluno adquira experiência matemática, Polya (1985) destaca que temos um problema sempre que procuramos os meios para atingir um objetivo. Segundo o autor, quando temos um desejo que não podemos satisfazer imediatamente, pensamos nos meios de satisfazê-lo e, assim, está colocado um problema.

Para Schoenfeld (1985), a realização de uma tarefa matemática nem sempre é a resolução de um problema. Ele define problema, num sentido relativo, como uma tarefa que é difícil para quem está tentando resolvê-la. Nessa perspectiva, ele explica que se alguém já tem acesso a um plano para a solução de uma tarefa matemática, essa tarefa é um exercício e não um problema.

Echeverría e Pozo (1998) concordam com esse autor ao entender que uma situação somente pode ser caracterizada como problema se ela for reconhecida como tal. Ou seja, não dispomos de meios automáticos para resolvê-la de forma mais ou menos imediata. Assim, para se chegar à solução, será necessário um processo de reflexão ou uma tomada de decisão sobre a sequência de passos a serem seguidos.

Van de Walle (2009) defende a proposição de atividades ou problemas de modo a envolver os alunos no pensar e desenvolver a Matemática importante que eles precisam aprender. Ele concorda com os outros autores ao definir "problema", como qualquer tarefa ou atividade na qual os estudantes não tenham algum método ou regra já memorizados.

Dentro dessa perspectiva, o Rali pretende propor situações para as quais os alunos não necessariamente dispõem de uma solução imediata, mas que possibilitam 
a "invenção" ou elaboração de uma estratégia para experimentar, conjecturar, verificar, justificar sua solução, para explicar o desenvolvimento de seu raciocínio. Dessa forma, os organizadores estabelecem que os problemas propostos devem ser inéditos (uma vez que se os alunos já conhecem a solução, não é mais um problema!), ricos e estimulantes para os alunos.

É a partir dessa definição que os problemas do Rali são caracterizados.

Além disso, Polya (1985, p. 14) classifica problemas entre rotineiros e não rotineiros:

O problema que não se resolve por rotina exige um certo grau de criação e originalidade por parte do aluno, enquanto o problema de rotina não exige nada disso. O problema a ser resolvido sem rotina tem alguma possibilidade de contribuir para o desenvolvimento intelectual do aluno, enquanto o problema de rotina não tem nenhuma. A linha de demarcação entre esses dois tipos de problemas pode não ser precisa, porém os dois casos extremos são claramente reconhecíveis.

Com essa distinção, podemos considerar os problemas propostos pelo Rali entre os não rotineiros, uma vez que nem sempre podem ser resolvidos aplicando direta e mecanicamente uma regra que o aluno não tem dificuldade alguma para encontrar, conforme indicou Polya (1985) a respeito dos problemas rotineiros.

Essas características são o que diferenciam problemas de exercícios, segundo Echeverría e Pozo (1998). Para esses autores, uma mesma situação pode representar um problema para uma pessoa e um exercício para outra. É possível que a segunda não a reconheça como problema por não se interessar pela situação, ou porque possui "mecanismos para resolvê-la com um investimento mínimo de recursos cognitivos e pode reduzi-la a um simples exercício" (ECHEVERRÍA; POZO, 1998, p. 16).

Assim, muitas vezes, não é possível determinar se uma tarefa é um problema ou um exercício. Isso depende, conforme destacam os autores acima citados, da experiência e conhecimento de quem executa a tarefa, além dos objetivos estabelecidos para sua realização.

Porém, é importante salientar que, para esses autores, as duas atividades exigem dos alunos a ativação tanto de conhecimentos e procedimentos diferentes, quanto diferentes atitudes, motivações e conceitos.

Na medida em que sejam situações mais abertas ou novas, a solução de problemas representa para o aluno uma demanda cognitiva e motivacional maior do que a execução de exercícios, pelo que, muitas vezes, os alunos não habituados a resolver problemas se mostram inicialmente reticentes e 
procuram reduzi-los a exercícios rotineiros (ECHEVERRÍA; POZO, 1998, p. 17).

Em Dante (2009), podemos encontrar uma classificação para problemas segundo os objetivos a que se propõem. Dentre os tipos de problemas relacionados por ele estão: exercícios de reconhecimento, exercícios de algoritmos, problemaspadrão simples ou compostos, problemas-processo ou heurísticos, problemas de aplicação e problemas quebra-cabeça. O Quadro 3, a seguir, mostra a distinção entre cada um destes tipos.

A maioria dos problemas do Rali podem ser caracterizados como problemasprocesso. Isso porque, segundo Dante (2009), esse tipo de problema não pode ser traduzido diretamente para a linguagem matemática, nem resolvido pela aplicação automática de algoritmos, pois exige do aluno um tempo para pensar e arquitetar um plano de ação, uma estratégia que pode levá-lo à solução.

Os organizadores do RMT não consideram os problemas do Rali como "problemas de aplicação" ou "situação problema". Enquanto Dante (2009) considera os dois tipos como sinônimos, para eles, um problema de aplicação é destinado a reforçar e assimilar conhecimentos ou estender o campo de aplicação, que fica geralmente no final da sequência de aprendizagem de uma noção. Já uma situação problema é destinada a construir novos conhecimentos, exigindo fases de pesquisa e envolvendo momentos de institucionalização, fases essas que se desenvolvem sobre uma longa duração.

Os problemas do Rali são considerados, então, problemas abertos, pois neles encontramos desafios, o prazer de procurar e até aspectos lúdicos.

Nesse caso, esses problemas se aproximam dos tipos descritos por Dante (2009) como problema-processo e problema de quebra-cabeça. 


\begin{tabular}{|c|c|c|}
\hline TIPO & OBJETIVO & EXEMPLO \\
\hline Exercícios de reconhecimento & $\begin{array}{l}\text { Fazer o aluno reconhecer, } \\
\text { identificar ou lembrar um } \\
\text { conceito específico, uma } \\
\text { situação, uma propriedade etc. }\end{array}$ & Qual é o sucessor de $78 ?$ \\
\hline Exercícios de algoritmos & $\begin{array}{l}\text { Treinar a habilidade em } \\
\text { executar um algoritmo (adição, } \\
\text { subtração, multiplicação e } \\
\text { divisão) e reforçar } \\
\text { conhecimentos anteriores. }\end{array}$ & $\begin{array}{l}\text { Efetue: } \\
\text { a) } 123+21 \\
\text { b) } 312-77 \\
\text { c) } 708 \times 32 \\
\text { d) } 142: 12\end{array}$ \\
\hline $\begin{array}{l}\text { Problemas-padrão simples e } \\
\text { Problemas-padrão compostos }\end{array}$ & $\begin{array}{l}\text { Recordar e fixar os fatos } \\
\text { básicos através dos } \\
\text { algoritmos, reforçando o } \\
\text { vínculo existente entre as } \\
\text { operações e situações do dia- } \\
\text { a-dia. Envolve a aplicação } \\
\text { direta de um (simples) ou mais } \\
\text { (compostos) algoritmos } \\
\text { aprendidos anteriormente, sem } \\
\text { exigir qualquer estratégia. }\end{array}$ & $\begin{array}{c}\text { Joana tem } 35 \text { balas. Ela quer } \\
\text { dar distribuí-las entre seus } 7 \\
\text { amigos de modo que cada um } \\
\text { receba a mesma quantidade de } \\
\text { balas. Quantas balas cada } \\
\text { amigo receberá? }\end{array}$ \\
\hline $\begin{array}{c}\text { Problemas-processo ou } \\
\text { heurísticos }\end{array}$ & $\begin{array}{l}\text { Desenvolver a criatividade, } \\
\text { iniciativa e espírito explorador. } \\
\text { Desenvolver estratégias e } \\
\text { procedimentos para resolver } \\
\text { situações-problema. }\end{array}$ & $\begin{array}{l}\text { Em um quintal, existem } \\
\text { somente galinhas e coelhos. } \\
\text { Ao todo são } 21 \text { animais e, } \\
\text { contando os pés das galinhas e } \\
\text { as patas dos coelhos, chega-se } \\
\text { a } 60 \text {. Quantas são as galinhas } \\
\text { e quantos são os coelhos? }\end{array}$ \\
\hline $\begin{array}{c}\text { Problemas de aplicação ou } \\
\text { situações-problema }\end{array}$ & $\begin{array}{l}\text { Levar o aluno a fazer } \\
\text { pesquisas e levantamento de } \\
\text { dados e, através de conceitos, } \\
\text { técnicas e procedimentos } \\
\text { matemáticos, matematizar uma } \\
\text { situação e resolver o problema. }\end{array}$ & $\begin{array}{l}\text { A escola passará por uma } \\
\text { reforma e todas as salas serão } \\
\text { pintadas. Qual valor deverá ser } \\
\text { reservado para a compra da } \\
\text { tinta? }\end{array}$ \\
\hline Problemas de quebra-cabeça & $\begin{array}{l}\text { Desafiar e motivar o aluno, } \\
\text { desenvolver a percepção com } \\
\text { a chamada Matemática } \\
\text { recreativa. }\end{array}$ & $\begin{array}{l}\text { Mova } 3 \text { palitos para formar } 3 \\
\text { quadrados: }\end{array}$ \\
\hline
\end{tabular}

Quadro 3: Tipos de Problemas segundo Dante (2009) 
A seguir, mostramos um exemplo de problemas do Rali que se enquadra na categoria de problemas do tipo processo.

\section{OS BISCOITOS DE EMILIA ${ }^{7}$ - Prova I - 13 Rali (2005)}

Emília fez biscoitos, entre 300 e 500.

Ela está pensando em como poderia embalá-los em vários saquinhos contendo o mesmo número de biscoitos:

- se ela coloca 9 biscoitos em cada saquinho, sobram 5;

- se ela coloca 8 biscoitos em cada saquinho, sobram 7;

- se ela coloca 12 biscoitos em cada saquinho, sobram 11;

- se ela coloca 16 biscoitos em cada saquinho, sobram 15.

\section{Quantos biscoitos Emília fez?}

\section{Expliquem como vocês chegaram na resposta.}

Alguns dos problemas do Rali, em particular os do domínio geométrico, que envolvem composição ou decomposição de figuras, também podem ser vistos como do tipo quebra-cabeça. Segue um exemplo deste tipo de problema, extraído de uma prova do Rali.

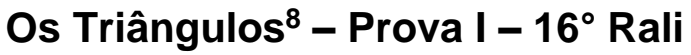
(2008)

Esta figura tem muitos triângulos.

Pierre contou 32, mas ele não sabe se encontrou todos.

Quantos triângulos podem ser vistos nesta figura?

Expliquem como vocês fizeram para contar todos os triângulos.

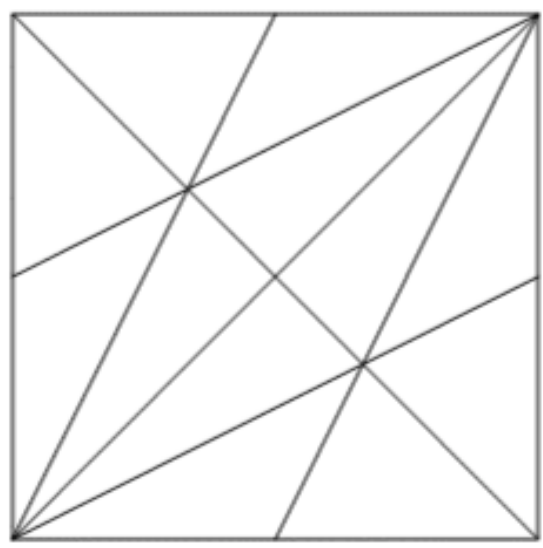

\footnotetext{
${ }^{7}$ Fonte: www.armtint.org, tradução nossa.
}

${ }^{8}$ Fonte: www.armtint.org, tradução nossa. 
Para Santos (1998), uma situação-problema pode ser caracterizada pelo conceito necessário à resolução: é aquele que é esperado que o aluno adquira. Nessa situação, é possível que o aluno construa seu próprio conhecimento. Já em um problema aberto, o enunciado não oferece condições favoráveis ao aluno de identificar os meios de resolução, ele deve formular hipóteses, verificá-las, elaborar meios de validá-las, demonstrando uma atitude científica.

Assim, segundo o que se propõe com os problemas do Rali, estes podem ser vistos como problemas não rotineiros, do tipo processo, de quebra cabeça ou abertos. No entanto, não devem ser considerados como problemas de aplicação ou situaçõesproblema, conforme descrito. Dessa forma, justifica-se o emprego desses problemas para motivar os alunos na busca por soluções, procurando estimulá-los na utilização de diferentes tipos de raciocínio matemático e utilizando diferentes representações, uma vez que estas estão relacionadas com apreensão conceitual, como veremos no próximo capítulo.

Como mencionamos na Introdução, durante o processo de resolução de um problema, devemos considerar as representações. Para Carreira (1999), os diferentes tipos de representações de ideias matemáticas são entendidos como ferramentas úteis na busca de soluções aos problemas propostos.

Na sequência, trataremos de aspectos sobre a abordagem teórica na qual se fundamentam os estudos que faremos, nesta relação entre resolução de problemas e representações, em particular, os registros de representação semiótica, na abordagem de R. Duval. 


\section{Capítulo 4}

\section{Representações na Resolução de Problemas}

\subsection{Representações Matemáticas}

Carreira (1999) considera que o conceito de representação tende a assumir diversas formulações de acordo com o contexto em que é utilizado. Ela se baseia nos Standards do NCTM (1989) para enfatizar o papel das representações externas no currículo de Matemática.

Segundo o que é destacado nesse documento, o papel a dar a essas representações é o de lentes através das quais os alunos poderão interpretar e analisar problemas e suas soluções. Com isso, a autora explica que, além de sugerir diferentes "visões" de um mesmo problema matemático, a metáfora sobre a lente exprime o caráter de "amplificadores conceituais" que certas representações podem adquirir quando aliadas à manipulação e exploração de ideias matemáticas.

Nos Standards 2000, junto ao Padrão de Resolução de Problemas (p. 31), encontramos o Padrão de Representações. Segundo o documento, programas institucionais devem habilitar todos os estudantes a:

- Criar e usar representações para organizar, registrar e comunicar ideias matemáticas;

- Selecionar, aplicar e traduzir representações matemáticas para resolver problemas;

- Usar representações para modelar e interpretar fenômenos físicos, sociais e matemáticos.

Dessa forma, Carreira (ibid.) observa a importância de o aluno ser capaz de optar por um certo tipo de representação e utilizá-la ao lidar com um problema. Além disso, para ela, o aluno deve ainda ser capaz de fazer com que a produção e manipulação de representações se torne uma forma ativa de construir conceitos matemáticos e de encontrar solução para problemas.

Em relação às representações, sob outra perspectiva, os trabalhos de Duval (2003) têm destaque devido à sua preocupação com o funcionamento cognitivo do 
aluno, numa situação em que se considera o objetivo de ensino como sendo a aquisição de conhecimento por parte do aluno. As pesquisas desse autor revelam a importância e a necessidade de um ensino pautado nos registros de representação semiótica para a aprendizagem em Matemática. É o que passaremos a discutir no tópico que segue.

\subsection{Registros de Representação Semiótica}

Em Matemática, o uso de representações é inevitável pois os objetos matemáticos não são diretamente acessíveis à percepção. Dessa forma, quando falamos em ensino de Matemática, devemos considerar as diferentes formas de representação de um mesmo objeto matemático, como conceitos, propriedades, estruturas e relações que podem expressar diferentes situações.

Assim, Duval (2012a) julga que a distinção entre um objeto e sua representação é um ponto estratégico para a compreensão da matemática, uma vez que, segundo ele, quando se confunde o objeto com sua representação, há uma perda de compreensão e os conhecimentos adquiridos tornam-se rapidamente inutilizáveis ao longo de seu contexto de aprendizagem.

Em Damm (2000), vemos as três aproximações da noção de representações estabelecidas por Duval:

- Representações como representação subjetiva e mental: para Duval (2012a), essas englobam o conjunto de imagens e, ainda, as conceitualizações que um indivíduo pode ter sobre um objeto, sobre uma situação e sobre o que lhe é associado.

- Representações internas ou computacionais: são internas e não conscientes do sujeito, que fazem com que ele execute certas tarefas sem pensar em todos os passos necessários para sua realização.

- Representações semióticas": "são produções constituídas pelo emprego de signos pertencentes a um sistema semiótico de representações que tem

\footnotetext{
${ }^{9}$ Num contexto geral, Santaella (2012, p. 19) define Semiótica como: "a ciência que tem por objeto de investigação todas as linguagens possíveis, ou seja, que tem por objetivo o exame dos modos de
} 
inconvenientes próprios de significação e de funcionamento" (DUVAL, 2012a, p.269). São representações conscientes, inseparáveis da visão que se tem de algo.

Conforme aponta Flores (2006), o interesse de Duval está, principalmente, no funcionamento cognitivo do aluno. Para este último autor, o pensamento está fortemente relacionado às operações semióticas e, consequentemente, não haverá compreensão possível sem o recurso às representações semióticas.

Para Duval ${ }^{10}$ (1995 apud DAMM, 2000), o papel fundamental específico da representação semiótica é que elas são um sistema particular de signos, por exemplo, língua natural, língua formal, escrita algébrica ou gráficos cartesianos. Segundo Duval (2012a), elas não são apenas usadas como simples meios de exteriorização de representações mentais para fins de comunicação, ou seja, para torná-las visíveis ou acessíveis a outrem, mas são igualmente essenciais à atividade cognitiva do pensamento.

Assim, ele considera que as representações mentais dependem da interiorização das representações semióticas e somente as representações semióticas permitem preencher algumas funções cognitivas. Para explicar esse fato, o autor utiliza os seguintes termos:

- Semiósis: apreensão ou produção de uma representação semiótica;

- Noésis: apreensão conceitual de um objeto.

Duval (ibid.) revela que para que ocorra a apreensão de um objeto matemático é necessário que a noésis (conceitualização) ocorra através de significativas semiósis (representações). Ou seja, não há noésis sem semiósis. Porém, não se trata de determinar várias representações de um mesmo objeto, mas, de coordenar diversos registros de representação semiótica para sua apreensão conceitual.

Por exemplo, segundo Nehring ${ }^{11}$ (1996 apud DAMM, 2000), não adianta o sujeito resolver uma operação usando material concreto ou através de um desenho

constituição de todo e qualquer fenômeno como fenômeno de produção de significação e de sentido". O nome vem do grego semeion, que quer dizer signos. Semiótica é a ciência dos signos.

10 DUVAL, R. Quel cognitive retenir en didatique des mathématiques? Actes de la 8 ème École et Université d'Été de Didactique des Mathématiques - Saint-Sauves d'Auverge. Édition IREM de Clermont-Ferrand, pp.198-225, 1995.

${ }^{11} \mathrm{NEHRING}$, C. A multiplicação e seus registros de representação nas séries iniciais. Dissertação de Mestrado, UFSC, 1996. 
se não puder enxergar ou coordenar esses procedimentos no algoritmo da operação, na resolução de um problema ou em outro registro de representação.

Conforme o que Duval (2012a) coloca, é essencial, na atividade matemática, poder mobilizar diferentes registros de representação semiótica (figuras, gráficos, escritas simbólicas, na língua natural, etc.) e, em uma atividade matemática, poder escolher um registro no lugar de outro.

Nesse sentido, um registro é entendido, então, como um sistema semiótico que tem funções cognitivas fundamentais no funcionamento cognitivo consciente. Em Matemática, são considerados principalmente quatro tipos de registros:

1) Língua natural: associações verbais com argumentações e deduções;

2) Figural: figuras geométricas planas ou espaciais, com apreensão operatória, perceptiva, sequencial e discursa;

3) Sistemas de escritas e cálculo: numéricas, algébricas, simbólicas;

4) Gráfico: mudanças de sistema de coordenadas, interpolação e extrapolação.

Em síntese, Duval (ibid.) procura evidenciar a forte ligação entre semiósis e noésis, no funcionamento cognitivo do pensamento. Para isso, ele exibe condições necessárias para favorecer a coordenação de registros e para organizar um ensino que leve em conta essa forte ligação.

Assim, esse autor estabelece três atividades cognitivas fundamentais ligadas à semiósis para que um sistema semiótico possa constituir um registro de representação:

1) Formação: ocorre a partir de uma seleção de características e de dados do conteúdo a ser representado. Por se tratar de uma tarefa que pode ser comparada a uma descrição, a formação de uma representação deve respeitar regras, cujas funções são assegurar as condições de identificação e reconhecimento da representação e a possibilidade de utilização. Pode ocorrer através da enunciação de uma frase (compreensível em determinada língua natural), composição de um texto, desenho de uma figura geométrica, elaboração de um esquema, expressão de uma fórmula.

2) Tratamento: transformação de uma representação no mesmo registro em que ela foi formada, ou seja, é uma transformação interna a um registro. $\mathrm{O}$ cálculo é uma forma de tratamento próprio das expressões simbólicas (cálculo numérico, cálculo algébrico, cálculo proposicional...). 
3) Conversão: transformação de uma representação em uma interpretação em outro registro, conservando total ou parcialmente o conteúdo da representação inicial. Trata-se de uma transformação externa ao registro de início (o registro da representação a converter). Temos, por exemplo, uma ilustração como a conversão de uma representação em língua natural em uma representação figural.

Para exemplificar a diferença e independência do tratamento em relação à conversão, Duval (2012a) utiliza o seguinte exemplo: alunos podem efetuar a adição de dois números com sua expressão decimal e com sua expressão fracionária, que necessitam o uso de tratamentos diferentes, e podem não pensar em converter, se isto for necessário, a expressão decimal de um número em sua expressão fracionária (e reciprocamente), ou mesmo não conseguir efetuar a conversão.

Assim, temos como exemplos de tratamento:

a) $0,25+0,25=0,5$.

b) $\frac{1}{4}+\frac{1}{4}=\frac{1}{2}$

E, como exemplos de conversão:

a) $\frac{1}{2}=0,5$

b) $\frac{1}{4}=25 \cdot 10^{-2}$

c) $\frac{1}{4}+\frac{1}{5}=0,20+0,25=0,45$

Nos três casos, há conversão do registro numérico fracionário para o registro numérico decimal.

Duval (ibid.) menciona a distinção entre conversão, codificação e interpretação, alertando que não se deve confundir as três atividades, já que:

- A interpretação requer uma mudança de quadro teórico ou uma mudança de contexto, o que não implica necessariamente mudança de registro.

- A codificação é a "transcrição" de uma representação em outro sistema semiótico diferente daquele em que é dado inicialmente. Esta transcrição é efetuada "em meio a uma série de substituições", aplicando regras de correspondência ou utilizando listas de substituições inicialmente estabelecidas. Estas substituições são efetuadas diretamente sobre os 
significantes que compõem a representação, sem considerar a organização da representação, nem o que ela representa.

Como exemplo de conversão de representação, temos a conversão entre a expressão algébrica de uma relação (coluna II da tabela a seguir) e sua representação gráfica cartesiana (coluna III da tabela a seguir).

\begin{tabular}{|l|c|c|}
\hline \multicolumn{1}{|c|}{$\begin{array}{c}\text { REGISTRO NA LINGUA } \\
\text { NATURAL (I) }\end{array}$} & $\begin{array}{c}\text { REGISTRO DO SISTEMA DE } \\
\text { ESCRITA (II) }\end{array}$ & REGISTRO GRÁFICO (III) \\
\hline $\begin{array}{l}\text { O conjunto de pontos do plano } \\
\text { que tem abscissa positiva. }\end{array}$ & $\mathrm{x}>0$ & \\
\hline $\begin{array}{l}\text { O conjunto de pontos do plano } \\
\text { cuja abscissa e ordenada têm } \\
\text { o mesmo sinal. }\end{array}$ & $\mathrm{xy}>0$ & \\
\hline
\end{tabular}

Quadro 4: Exemplos de Conversões

Fonte: Duval (2009, p. 76)

O exemplo indicado na tabela faz parte de uma pesquisa realizada por Duval com 105 estudantes. A tarefa que necessitava da conversão $\mathrm{I} \rightarrow$ III consistia em hachurar a parte do gráfico que continha a informação do registro na língua natural. Para a conversão $I I I \rightarrow I$, havia apenas uma escolha entre várias expressões que correspondia ao gráfico hachurado.

Os resultados dessa pesquisa mostraram maior dificuldade dos alunos em fazer o segundo tipo de conversão. Isso porque ela exige que as unidades significantes propostas para cada registro sejam bem discriminadas.

No registro gráfico, é preciso ter claro e saber identificar as características visuais desse tipo de representação. No caso da atividade proposta por Duval, as variáveis gerais a serem consideradas eram: de implantação (o que se destaca como figura sobre o fundo: uma linha ou uma região) e relativa à forma da tarefa (a linha traçada que delimita ou não uma região é reta ou curva; e se for curva, ela é aberta ou fechada). 
$\mathrm{Na}$ expressão algébrica, é necessário identificar os significados de cada símbolo (cada um corresponde a uma unidade significativa) e não somente considerálos como objetos. Tem-se, nesse caso: símbolos relacionais $(<,>,=, \ldots)$, símbolos de operações ou de sinais $(+,-)$, símbolos de variável, de expoente, de coeficiente e de constante.

Assim, para a realização da conversão $\mathrm{III} \rightarrow \mathrm{I}$, era preciso identificar todas as modificações possíveis da imagem e realizar uma interpretação global. Duval (2011a) destaca que, nessa tarefa, há uma associação variável visual de representação unidade significativa da expressão algébrica.

Nas atividades de conversão, Duval (2009) chama atenção para o fenômeno da não congruência, o que pode explicar as dificuldades dos alunos em realizar certas conversões em determinados sentidos.

A congruência entre a representação de partida e a representação de chegada é vista como uma conversão trivial e, segundo o autor, poderia quase ser considerada, intuitivamente, como uma simples codificação. Isso porque há uma correspondência termo a termo entre os dois registros, como no exemplo a seguir.

\begin{tabular}{|l|c|}
\hline \multicolumn{1}{|c|}{ Registro da língua natural } & Registro do sistema de escrita \\
\hline $\begin{array}{l}\text { O conjunto dos pontos do plano cartesiano que } \\
\text { têm a abscissa maior que zero. }\end{array}$ & $x>0$ \\
\hline
\end{tabular}

Quadro 5: Exemplo de congruência entre representações

Quando não há congruência, não somente a conversão torna-se custosa em termos de tempo de tratamento, mas pode ainda criar uma dificuldade para o sujeito que não identifica características do objeto e como podem ser representadas no outro sistema. Nesse caso, a representação de partida precisa ser reorganizada para que se obtenha a expressão correspondente no registro de chegada, ou seja, não há correspondência termo a termo entre os dois registros.

\begin{tabular}{|l|c|}
\hline \multicolumn{1}{|c|}{ Registro da língua natural } & Registro do sistema de escrita \\
\hline $\begin{array}{l}\text { O conjunto dos pontos do plano cartesiano cujas } \\
\text { coordenadas têm o mesmo sinal. }\end{array}$ & $x . y>0$ \\
\hline
\end{tabular}

Quadro 6: Exemplo de não congruência entre representações 
No exemplo acima, a conversão do registro da língua natural para a inequação não se faz de forma direta: a unidade de significado presente no registro de partida (ter o mesmo sinal) não se identifica imediatamente com a expressão algébrica no registro simbólico-algébrico (produto estritamente positivo). Para realizar tal conversão, é necessária uma interpretação da unidade informacional.

Para Duval (2012a), não existe uma regra que possa determinar, a priori, todos os casos de não congruência entre as representações em dois registros determinados. Portanto, na elaboração de atividades de ensino, devem-se considerar tarefas que tratam dos dois sentidos da conversão. Além disso, essa sequência deve ser constituída por tarefas que comportem casos de congruência e de não congruência, nos dois sentidos de conversão.

O autor destaca ainda que, no ensino de Matemática, em geral, levam-se em conta apenas as atividades de formação e tratamento. Atividades de conversão não recebem a devida atenção pois, considera-se que:

- A conversão ocorre naturalmente a partir da capacidade de se formar representações em diferentes registros e efetuar tratamentos sobre essas conversões;

- A conversão não tem função no processo de compreensão dos objetos ou conteúdos representados, uma vez que uma mudança de registro é suficiente para tal.

Duval discorda dessas duas ideias sobre as conversões, pois, para ele, na aprendizagem, a conversão desempenha um papel essencial na conceitualização. O Autor destaca que a compreensão integral de um conteúdo conceitual se baseia na coordenação de ao menos dois registros de representação, manifestando-se pela rapidez e espontaneidade da atividade cognitiva de conversão.

Nesse contexto, pretendemos enfatizar o uso de diferentes representações semióticas em atividades de resolução de problemas visando a auxiliar os estudantes na aquisição dessas habilidades.

Conforme Duval explica, quando não há coordenação entre registros de representação, existe o que ele chama de isolamento de registros. Esse isolamento não impede toda a compreensão, no entanto torna os conhecimentos adquiridos pouco ou não utilizáveis em outras situações onde poderiam ser utilizados e, além disso, conduz a um trabalho em que não há possibilidade de controle do "sentido" daquilo que é feito. 
Enfim, conforme já observado, a conceitualização implica coordenação de pelo menos dois registros de representação. Logo, a aprendizagem matemática não pode ser somente a automatização de certos tratamentos ou a compreensão de noções, mas passa também pela coordenação de diferentes registros de representação, necessariamente mobilizados por esses tratamentos ou por essa compreensão.

A resolução de problemas depende, inicialmente, da compreensão do enunciado do problema, identificando o que é dado e o que é pedido. De uma forma geral, a resolução de um problema envolve produção de representações e, com isso, atividades de tratamento e/ou conversões. Normalmente, trata-se de passar de uma descrição discursiva dos objetos relevantes no enunciado do problema para representações (simbólicas, figurais, gráficas, etc.) e suas relações. Tais relações podem ser marcadas linguisticamente de modo muito variável no texto do enunciado.

Em particular, os problemas propostos nas provas do Rali Matemático possuem diversas possibilidades de representações semióticas (por meio de desenho, cálculo, equações etc.), de modo que podem ser resolvidos de diferentes maneiras, permitindo enriquecer e estimular confrontos de soluções e discussões.

Assim, durante a discussão dos problemas, o enfoque será dado às diferentes maneiras de representação, buscando analisar o papel dessas representações no desempenho dos alunos em atividade de resolução de problemas.

No processo de resolução de problemas que envolvem Geometria, as figuras têm papel intuitivo e heurístico de grande importância. Portanto, destacamos a seguir as principais características dos registros figurais e, ainda na perspectiva de Duval, descreveremos o que envolve um processo de visualização.

\subsubsection{Registro Figural em Geometria}

Os registros figurais aparecem na resolução de problemas de Geometria como auxiliares, por vezes permitindo acesso mais fácil à ideia da solução. Para Duval (2012b), as atividades de construção de figuras podem "ensinar a ver", isto é, permitem descobrir, mobilizar ou controlar a produtividade heurística delas. No entanto, cabe destacar: 
[...] ver uma figura em geometria é uma atividade cognitiva mais complexa do que o simples reconhecimento daquilo que uma imagem mostra. Isto depende do papel que a figura tem na atividade matemática (DUVAL, 2012b, p. 118).

O autor coloca a hipótese de que essa maneira de ver depende das operações de reorganização puramente visuais das figuras, que seriam próprias da maneira matemática de "ver" e, por esse motivo, estabelece que "as figuras formam um registro de representação semiótico específico" (DUVAL, 2011b, p. 85).

Nesse sentido, reconhecendo que a heurística de problemas de Geometria está relacionada a um registro de representações que originam formas de interpretações autônomas, quatro maneiras de apreensão de uma figura são elencadas por Duval: apreensão sequencial, apreensão perceptiva, apreensão discursiva e apreensão operatória. Abaixo, detalharemos cada tipo de apreensão.

- Apreensão perceptiva: permite identificar ou reconhecer imediatamente um objeto matemático ou a forma de um objeto no plano e no espaço.

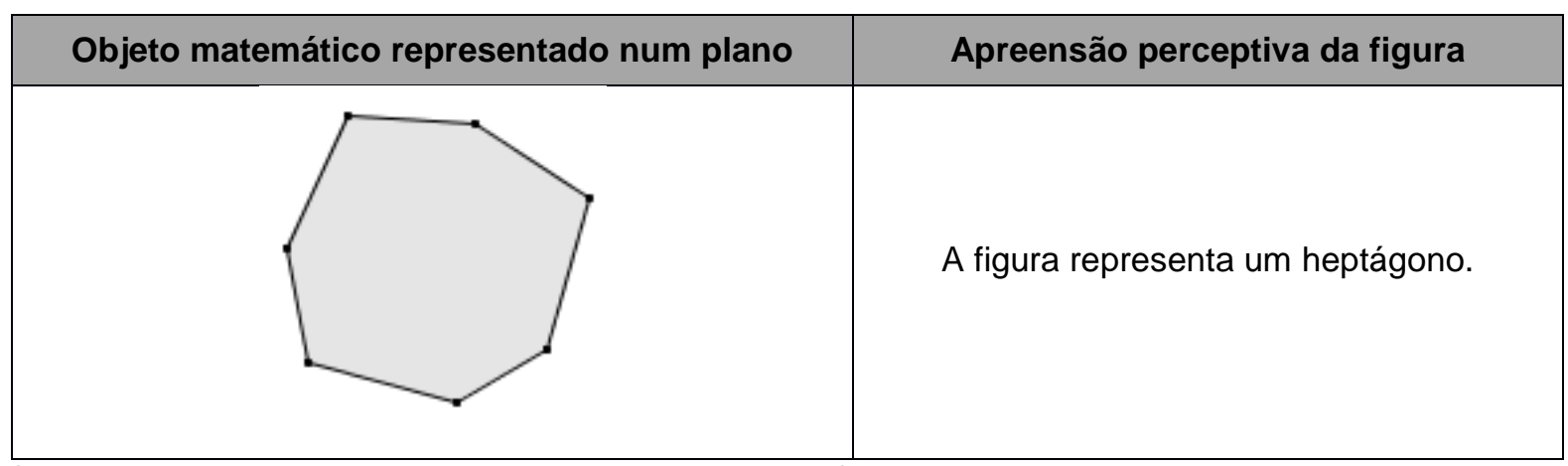

Quadro 7: Exemplo de apreensão perceptiva de uma figura

Duval caracteriza a apreensão perceptiva como imediata ou automática, independente do enunciado. Por outro lado, ele considera que nem sempre o que é exposto no enunciado aparece espontaneamente numa figura, o que torna necessária a interpretação comandada pelas hipóteses. A diferença entre essas duas atitudes gera um problema que, segundo o autor, faz com que a apreensão perceptiva das figuras possa ter um papel facilitador ou inibidor sobre a compreensão do problema colocado.

Para Duval (2012b), isso se revela quando, na resolução de um problema, estudantes se apegam à apreensão perceptiva e não buscam informações nas propriedades da figura ou em condições formuladas como hipóteses no enunciado, o 
que marca, conforme destaca o autor, a ausência da atitude chamada de interpretação discursiva da figura.

Nesse sentido, um aluno que se limita à apreensão perceptiva tem maior facilidade para resolver problemas em que a conversão do registro em língua natural (enunciado) para o registro figural seja congruente.

- Apreensão discursiva: corresponde a uma explicitação de outras propriedades matemáticas da figura além daquela(s) indicada(s) por uma legenda ou pelas hipóteses.

No exemplo a seguir, vemos que a apreensão perceptiva aparece subordinada à apreensão discursiva, pois o que é "dito" explicita elementos e propriedade que não seriam vistos somente a partir do registro figural.

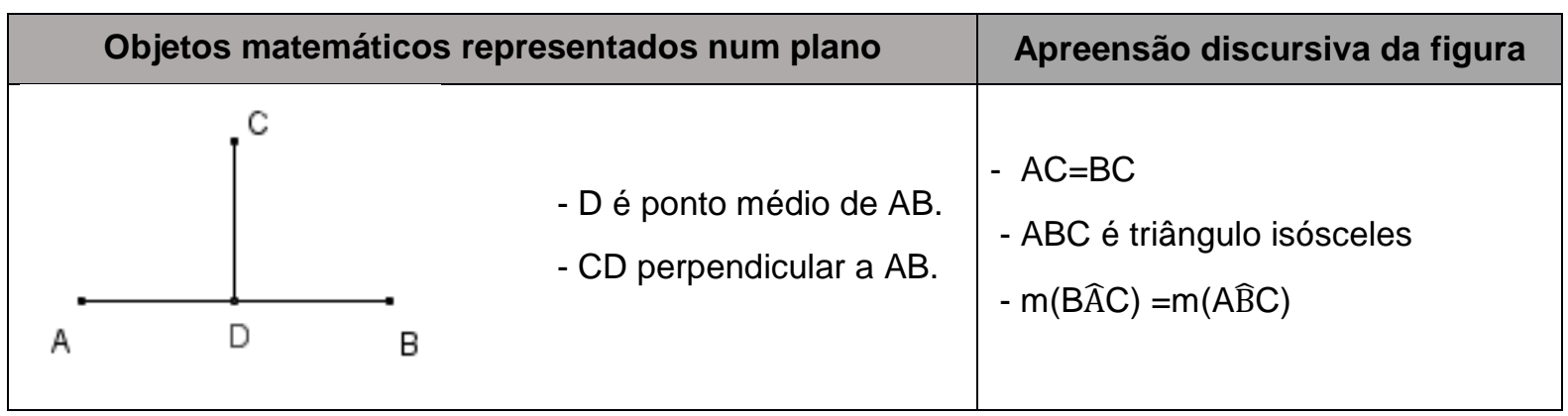

Quadro 8: Exemplo de apreensão discursiva de uma figura

- Apreensão sequencial: atividades de construção ou de descrição, tendo por objetivo a reprodução de uma dada figura, utilizando instrumentos (régua, compasso, software etc.).

\section{Apreensão sequencial de um triângulo equilátero}

Passo 1: traçar um segmento BC.

Passo 2: traçar a circunferência de centro B e raio BC. Passo 3: traçar a outra circunferência de centro C e raio $\mathrm{CB}$.

Passo 4: criar a intersecção das duas circunferências e nomeá-la de $\mathrm{A}$.

Passo 5: traçar os segmentos AB e AC.

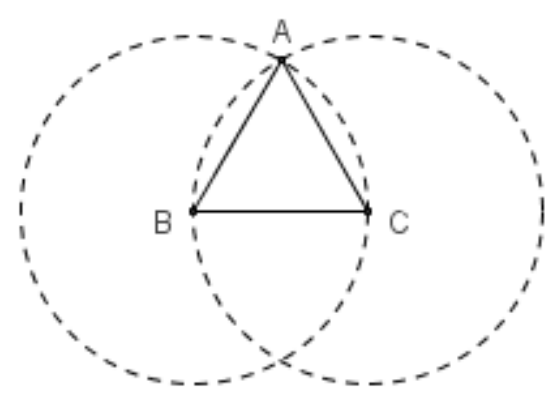

Quadro 9: Exemplo de apreensão sequencial de uma figura 
Na resolução de um problema, quando as apreensões perceptiva e discursiva de uma figura não são suficientes, é preciso considerar sua apreensão operatória.

- Apreensão operatória: corresponde a transformar ou a modificar a figura dada em outras figuras para obter novos elementos que poderão levar à ideia da solução de um problema ou de uma prova.

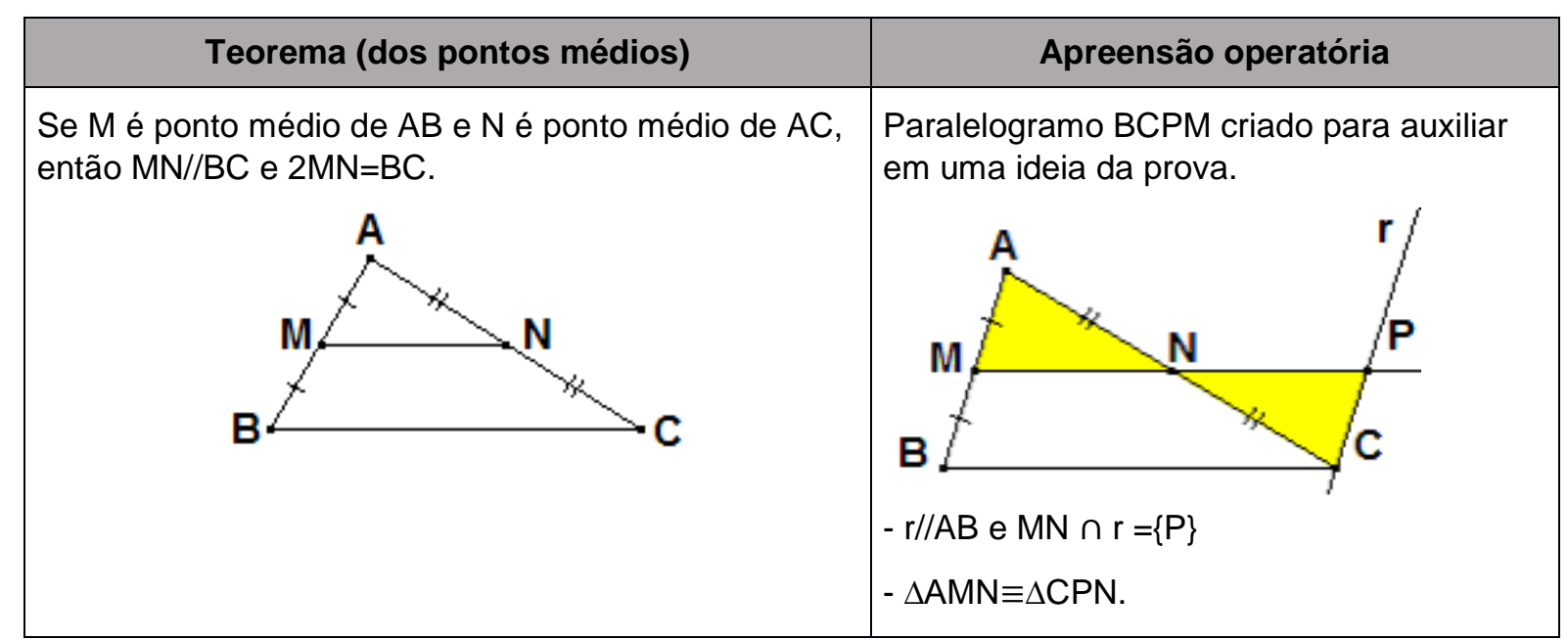

Quadro 10: Exemplo de apreensão operatória

Duval considera importante a distinção entre apreensão operatória de figuras e apreensões perceptiva e discursiva, porque os tratamentos que constituem a produtividade heurística das figuras geométricas combinam operações que não se mostram ser nem do tipo de apreensão puramente perceptiva, nem puramente discursiva. Mais detalhadamente, podemos ver as características da apreensão operatória no Quadro 11.

Aqui, trataremos com mais detalhes o tipo de modificação mereológica. Tratase da divisão de uma figura em unidades figurais que, quando recombinadas, resultam em uma outra figura.

A divisão de uma figura e a análise de suas partes - combinando-as e recombinando-as - permite a operação de reconfiguração. Para Duval, a reconfiguração é um tratamento que possibilita a comparação e, eventualmente, o reagrupamento de subfiguras de uma figura a partir de sua divisão. Quando for o caso, pode-se, ainda, incluir certo número de partes da figura, fazendo a divisão de suas unidades elementares. Assim, obtém-se uma figura diferente daquela dada inicialmente. 


\begin{tabular}{|l|l|l|}
\hline \multicolumn{3}{|c|}{ APREENSÃO OPERATÓRIA DE UMA FIGURA } \\
\hline Tipos de modificações figurais & $\begin{array}{l}\text { Operações que modificam a } \\
\text { figura: processo heurístico }\end{array}$ & $\begin{array}{l}\text { Fatores internos que disparam } \\
\text { ou inibem a visibilidade destas } \\
\text { operações }\end{array}$ \\
\hline $\begin{array}{l}\text { Mereológica (relação } \\
\text { parte/todo) }\end{array}$ & $\begin{array}{l}\text { - reconfiguração: uma figura se } \\
\text { decompõe em diferentes } \\
\text { unidades figurais. Elas podem } \\
\text { ser combinadas em outra } \\
\text { figura ou em diferentes } \\
\text { subfiguras. }\end{array}$ & $\begin{array}{l}\text { - partição em diversas } \\
\text { subfiguras pertinentes; } \\
\text { - convexidade ou não das } \\
\text { subfiguras; } \\
\text { - complementariedade; } \\
\text { - duplicação. }\end{array}$ \\
\hline \multirow{5}{*}{ Ótico } & $\begin{array}{l}\text { - a mesma forma e orientação } \\
\text { no plano fronto-paralelo, mas } \\
\text { com variação de tamanho: } \\
\text { superposição em profundidade } \\
\text { de duas figuras semelhantes; } \\
\text { - variação do plano em relação } \\
\text { ao plano fronto-paralelo } \\
\text { (variação de forma e } \\
\text { constância de forma e de } \\
\text { tamanho). }\end{array}$ & $\begin{array}{l}\text { - a mesma orientação das } \\
\text { figuras (objeto e imagem); } \\
\text { todas distintas dos lados das } \\
\text { duas figuras; } \\
\text { - centro de homotetia no } \\
\text { interior ou no exterior do } \\
\text { contorno convexo envolvendo } \\
\text { as duas figuras. }\end{array}$ \\
\hline \multirow{5}{*}{ De posição } & $\begin{array}{l}\text { - O mesmo tamanho e forma, } \\
\text { mas com variação de } \\
\text { orientação, rotação, translação, } \\
\text {.. }\end{array}$ & $\begin{array}{l}\text { - predominância das direções } \\
\text { vertical e horizontal }\end{array}$ \\
\hline
\end{tabular}

Quadro 11: Tipos de apreensões operatórias de figuras

Fonte: Duval (2012a, p. 288)

A operação de reconfiguração, segundo Flores e Moretti (2004), possibilita o uso de figuras com sua função heurística na resolução de problemas.

Segundo Duval (2012b), a produtividade heurística de uma figura, em um problema de Geometria, está ligada à existência da relação entre as operações possíveis, na figura, e um dos tratamentos matemáticos viáveis para o problema proposto.

A modificação de uma figura pode ser obtida pelo fracionamento em partes homogêneas ou heterogêneas. As definições dos dois tipos de fracionamento são dadas abaixo.

- Homogêneo: as partes obtidas na divisão da figura têm a mesma forma que o todo. A mais familiar é o quadriculado.

- Heterogêneo: as partes obtidas na divisão da figura têm formas diferentes daquelas do todo; por exemplo, repartir um quadrilátero em triângulos.

Examinar uma figura a partir de suas partes elementares origina a operação de reconfiguração intermediária. Com essa operação, é possível desenvolver tratamentos tais como "a medida de área através da soma das partes elementares ou 
do reconhecimento da equivalência de dois reagrupamentos intermediários" (DUVAL, 2012b, p. 128). A seguir, são exibidos alguns exemplos ${ }^{12}$ para ilustrar a operação de reconfiguração.

\begin{tabular}{|c|c|c|}
\hline Figura inicial & $\begin{array}{c}\text { Reconfiguração } \\
\text { intermediária }\end{array}$ \\
$\begin{array}{c}\text { Obter a área da figura pintada } \\
\text { contida no retângulo de lados } \\
\text { 4cm e 5cm. }\end{array}$ & $\begin{array}{c}\text { Reconfiguração } \\
\text { intermediária }\end{array}$ \\
forma global de vaso na forma \\
de um retângulo.
\end{tabular}

Quadro 12: Reconfiguração - Exemplo 1

\begin{tabular}{|c|c|c|c|}
\hline Figura inicial & $\begin{array}{c}\text { Reconfiguração } \\
\text { intermediária }\end{array}$ \\
Qual é a área da figura pintada \\
contida no quadrado de lado \\
2cm?
\end{tabular} $\begin{gathered}\begin{array}{c}\text { Modifica-se a figura inicial } \\
\text { mentalmente, graficamente ou } \\
\text { materialmente. }\end{array} \\
\begin{array}{c}\text { A reconfiguração transforma a } \\
\text { figura inicial em um retângulo. }\end{array}\end{gathered}$

Quadro 13: Reconfiguração - Exemplo 2

\begin{tabular}{|l|l|}
\hline Mostrar que a soma das medidas dos ângulos anicial \\
internos de um triângulo é igual a $180^{\circ}$.
\end{tabular}

Quadro 14: Reconfiguração - Exemplo 3

${ }^{12}$ Exemplos extraídos de material didático elaborado pelos professores Ana Paula Jahn (IME-USP) e Vincenzo Bongiovanni (Universidade Anhanguera), que será objeto de publicação. 




Quadro 15: Reconfiguração - Exemplo 4

Devido à particularidade de os problemas geométricos envolverem registro figural, e ao que foi discutido nessa seção, optamos por incluir, no experimento, esse tipo de problema, em especial, aqueles em que registros figurais estejam presentes no enunciado.

Para Duval, a resolução de problemas em Geometria e a forma de desenvolvimento do raciocínio que essa resolução demanda, depende das diferentes apreensões de figuras, em especial, a perceptiva, a discursiva e a operatória. Sendo assim, buscamos propor problemas cuja resolução requer reconfiguração, visando analisar como esse tipo de apreensão se manifesta nos alunos.

Os problemas escolhidos para o experimento, bem como suas análises, serão exibidos no próximo capítulo. 


\section{Capítulo 5}

\section{Metodologia}

\subsection{Descrição da Metodologia}

A presente pesquisa compreende um estudo experimental, cujas análises foram de natureza qualitativa, envolvendo a elaboração, realização e análise de situações de resolução de problemas junto a alunos do Ensino Médio, com ênfase no uso de diferentes representações.

Segundo as características de investigações qualitativas descritas por Bogdam \& Biklen (1994), neste estudo, o interesse está direcionado mais ao processo e significados construídos pelos alunos do que às causas e efeitos, uma vez que buscamos compreender particularidades da situação. Dessa maneira, assim como coloca Alves (2001), essa abordagem nos permite excluir generalizações do tipo estatístico, sendo a análise e a interpretação dos dados predominantemente descritivos.

A inspiração para o planejamento e a elaboração do experimento vieram do trabalho de Fagnant \& Vlassis (2013), com as necessárias adaptações, principalmente, devido ao nível de escolaridade dos alunos pesquisados e à complexidade dos problemas que servem de base para a experimentação.

Conforme já mencionado, o experimento foi dividido em três fases, cada uma subdividida em etapas. Em uma das etapas de cada fase, os alunos resolveram "provas" contendo, cada uma, três problemas extraídos do bando de questões do Rali Matemático. Os problemas da segunda prova foram adaptados, de modo que houvesse uma sugestão de representação para a situação proposta. Dessa forma, a fonte direta dos dados foi, principalmente, as produções dos alunos em atividade de Resolução de Problemas.

Consideramos que a interação com os sujeitos seria de grande importância para que pudéssemos perceber a maneira como eles vivenciariam a experiência. Sendo assim, outros dados foram obtidos a partir das respostas dos alunos a um questionário inicial a respeito de suas relações com a Matemática e com a Resolução 
de Problemas, de uma atividade que visava à distinção entre problema e exercício e de relatórios de observação de cada encontro. Ao final, outro questionário, que nos permitiu avaliar o modo como eles se enxergam quando inseridos no experimento.

Buscando compreender o papel das representações na atividade de resolução dos problemas, as análises dos resultados obtidos na pesquisa, tiveram apoio nos estudos de Duval $(2009,2011,2012)$ a respeito dos registros de representações semióticas e aprendizagem matemática.

A seguir, tecemos considerações sobre os sujeitos da pesquisa, bem como sobre a organização do experimento a ser realizado.

\subsection{Sujeitos da Pesquisa}

O estudo foi realizado numa escola estadual da Zona Oeste da cidade de São Paulo, com alunos de três turmas de $1^{\circ}$ ano do Ensino Médio.

A escola em questão é jurisdicionada à Diretoria de Ensino Centro Oeste faz e parte do programa Ensino Integral, um novo modelo de Ensino Médio proposto pela Secretaria de Educação do Estado de São Paulo. Segundo as Diretrizes estabelecidas pela Secretaria, nesse programa:

\footnotetext{
Não apenas o desenho curricular dessas escolas é diferenciado, mas também a sua metodologia, o modelo pedagógico e o modelo de gestão escolar, enquanto instrumento de planejamento, gerenciamento e avaliação das atividades de toda comunidade escolar (SÃO PAULO, 2012, p. 12).
}

Dentre as diferenças que descrevem esse modelo de escola, podemos destacar, por exemplo, o Protagonismo Juvenil, considerado um dos princípios educativos do modelo. Segundo o documento citado acima, o Protagonismo Juvenil é um processo no qual o jovem é sujeito e objeto das ações no desenvolvimento de suas próprias potencialidades. Dessa forma, ele é responsável por conduzir suas ações tornando-se autônomo à medida em que é capaz de avaliar e decidir, com base nas suas crenças, valores e interesses.

Com a ênfase no Protagonismo Juvenil como base do programa, o Projeto de Vida é visto como uma das funções sociais da escola. Nesse projeto cabe, à escola 
e, em particular, aos professores, apoiar os estudantes na sua própria construção por meio de ações que os motivem a fazer bom uso dessas oportunidades educativas.

$\mathrm{Na}$ escola integral, o aluno tem a oportunidade de se inscrever em disciplinas eletivas com o objetivo de ampliar seu universo cultural. Trabalha-se, ainda, com o acolhimento como estratégia para sensibilizar o estudante em torno de um novo projeto escolar. Avaliações, nivelamento, orientação de estudos estão inseridas como estratégias metodológicas para a realização de melhoria da aprendizagem do aluno.

Essa escola atende apenas alunos de Ensino Médio, portanto, os alunos do $1^{\circ}$ ano chegam de outras escolas, da região ou não. Grande parte desses alunos reside em regiões mais afastadas, inclusive na área metropolitana. Isso ocorre, geralmente, porque os pais trabalham próximo à escola e a consideram melhor localizada e, também, em termos de ensino e estrutura, melhor que as escolas que atendem as regiões onde moram.

Para obter mais informações sobre a escola, buscamos os resultados obtidos em Matemática nas avaliações externas, comparando-os com os de outras escolas da rede estadual. O último resultado, divulgado em 2013, fornece a média obtida no SARESP - Sistema de Avaliação de Rendimento Escolar do Estado de São Paulo. Nessa avaliação, cuja nota máxima é 500 pontos, a média ${ }^{13}$ alcançada em Matemática foi de 316,5. Uma média superior à das outras escolas, no mesmo segmento de ensino: da rede estadual $(268,7)$, estaduais do município $(261,3)$ e da mesma diretoria de ensino $(278,6)$.

Dessa forma, vemos que além do diferencial de ser uma escola do programa de Ensino Integral, trata-se de uma escola cujos alunos mostram bom desempenho em Matemática, pelo menos segundo os dados do SARESP.

Considerando nosso tema de estudo, nos interessou conhecer, ainda, qual a relação dos alunos com a Resolução de Problemas antes de iniciar a pesquisa. Com esse objetivo, a primeira fase do estudo se iniciou com um questionário, como será descrito na sequência.

\footnotetext{
${ }^{13}$ Disponível em: http://saresp.fde.sp.gov.br/. Acesso em: 9 ago. 2014.
} 


\subsection{Apresentação do Dispositivo Experimental}

No Quadro 16 temos uma visão geral da organização do experimento realizado.

\begin{tabular}{|c|c|c|c|}
\hline \multicolumn{4}{|c|}{ Quadro Sinóptico do Dispositivo Experimental } \\
\hline \multicolumn{2}{|c|}{ Fases do Estudo } & Atividades & $\begin{array}{c}\text { Instrumentos de coleta } \\
\text { de dados }\end{array}$ \\
\hline \multirow{3}{*}{ Fase 1} & \multirow{3}{*}{$\begin{array}{l}\text { Relações pessoais } \\
\text { dos sujeitos sobre } \\
\text { a Resolução de } \\
\text { Problemas }\end{array}$} & $\begin{array}{l}\text { Etapa } 1 \text { (duração: } 2 \text { x 50min.) } \\
\text { Atividade inicial: Problema e } \\
\text { Exercício, em dupla. } \\
\text { Questionário inicial } \\
\text { Apresentação do Rali } \\
\text { Matemático }\end{array}$ & \multirow{3}{*}{$\begin{array}{l}\text { Produções escritas (das } \\
\text { duplas ou grupos) } \\
\text { Respostas ao } \\
\text { questionário } \\
\text { Notas de observação }\end{array}$} \\
\hline & & $\begin{array}{l}\text { Etapa } 2 \text { (duração: } 1 \text { x 50min.) } \\
\text { Prova I: Resolução, em grupo, } \\
\text { de } 3 \text { problemas do Rali } \\
\text { Matemático }\end{array}$ & \\
\hline & & $\begin{array}{l}\text { Etapa } 3 \text { (duração: } 2 \text { x 50min.) } \\
\text { Discussão dos problemas da } \\
\text { Prova I com ênfase no uso de } \\
\text { diferentes representações }\end{array}$ & \\
\hline \multirow[b]{2}{*}{ Fase 2} & \multirow{2}{*}{$\begin{array}{l}\text { Exploração de } \\
\text { diferentes } \\
\text { representações na } \\
\text { resolução de } \\
\text { problemas }\end{array}$} & $\begin{array}{l}\text { Etapa } 1 \text { (duração: } 1 \text { x 50min.) } \\
\text { Prova II: Resolução, em grupo, } \\
\text { de } 3 \text { problemas do Rali, com } \\
\text { indicação de representação a } \\
\text { ser utilizada }\end{array}$ & \multirow{2}{*}{$\begin{array}{l}\text { Produções escritas dos } \\
\text { grupos (respostas da } \\
\text { Prova II) } \\
\text { Notas de observação }\end{array}$} \\
\hline & & $\begin{array}{l}\text { Etapa } 2 \text { (duração: } 2 \text { x 50min) } \\
\text { Discussão dos problemas da } \\
\text { Prova II com ênfase nas } \\
\text { diferentes representações } \\
\text { possíveis para resolução }\end{array}$ & \\
\hline \multirow{2}{*}{ Fase 3} & \multirow{2}{*}{$\begin{array}{l}(\text { Re)Utilização de } \\
\text { representações na } \\
\text { Resolução de } \\
\text { Problemas }\end{array}$} & $\begin{array}{l}\text { Etapa } 1 \text { (duração: } 1 \text { x 50min) } \\
\text { Prova III: Resolução de } 3 \\
\text { problemas do Rali }\end{array}$ & \multirow{2}{*}{$\begin{array}{l}\text { Produções escritas dos } \\
\text { grupos (respostas da } \\
\text { Prova III) } \\
\text { Respostas ao } \\
\text { questionário } \\
\text { Notas de observação }\end{array}$} \\
\hline & & $\begin{array}{l}\text { Etapa } 2 \text { (duração: } 1 \text { x 50min) } \\
\text { Questionário final }\end{array}$ & \\
\hline
\end{tabular}

Quadro 16: Quadro sinóptico do dispositivo experimental 
A pesquisa foi conduzida em três fases baseadas nas produções dos alunos em provas que seguem os princípios do Rali Matemático Transalpino, com exceção das atividades da primeira etapa da Fase 1, como veremos adiante.

$\mathrm{Na}$ sequência, apresentamos, de forma detalhada, cada uma das fases, especificando os objetivos e as atividades previstas em cada uma delas.

Os problemas do Rali selecionados para compor as fases do experimento fazem parte de provas já realizadas em edições anteriores da competição e se interrelacionam pelas possíveis representações envolvidas no processo de resolução. Cada problema será exibido seguido da análise a priori ${ }^{14}$ formulada pelos organizadores da competição, com algumas complementações. Os elementos descritos na análise são considerados na avaliação das respostas dadas pelos alunos.

\subsubsection{Descrição da Fase 1}

\subsubsection{Fase 1 - Etapa 1}

A Etapa 1 desta fase compreende três atividades, a serem realizadas ao longo de duas aulas de 50 minutos de duração cada. Os principais objetivos dessa etapa são:

- Fazer com que os estudantes compreendam a diferença entre um exercício e um problema;

- Fazer com que os estudantes tenham um primeiro contato com uma atividade de Resolução de Problemas em grupo;

- Conhecer a relação dos estudantes com a disciplina de Matemática, suas experiências em Resolução de Problemas e suas opiniões a respeito do significado de problema matemático;

- Apresentar o Rali Matemático.

$\mathrm{Na}$ atividade inicial, é pedido que os alunos, em duplas, encontrem a solução para duas questões que envolvem conceitos matemáticos. A primeira delas pode ser

\footnotetext{
${ }^{14}$ Todos os problemas e análises a priori fazem parte do material organizado pela Associação Rali Matemático Transalpino, disponível em: http://www.armtint.org/, com tradução nossa do original em Francês. Último acesso em: 13 nov. 2014
} 
caracterizada como um exercício, no sentido apresentado no Capítulo 3 (p. 38). A segunda, se enquadra na definição de problema, uma vez que sua resolução demanda interpretação e escolha de propriedades e conhecimentos a serem aplicados, além de apreensão operatória das figuras geométricas envolvidas. Assim, a resposta não poderia ser obtida de forma imediata. Ela faz parte do Banco de Questões da Olimpíada Brasileira de Matemática das Escolas Públicas (OBMEP, $2010)^{15}$.

A realização dessa atividade justifica-se, pois, segundo Echeverría e Pozo (1998, p.17), os limites entre a solução de problemas e a realização de exercícios nem sempre são fáceis de estabelecer.

Entretanto, é importante que nas atividades de sala de aula a distinção entre exercícios e problemas seja bem definida e, principalmente, que fique claro para o aluno que as tarefas exigem algo mais de sua parte do que o simples exercício repetitivo.

Nessa atividade, os alunos só podem conversar entre si, não tendo qualquer auxílio da professora ou da pesquisadora, do mesmo modo como é proposto nas instruções do Rali.

Responda:

1 - Qual a medida da hipotenusa de um triângulo retângulo cujos catetos medem 3 e 4 cm?

2 - Lado do quadrado - Quatro peças iguais, em forma de triângulo retângulo, foram dispostas de dois modos diferentes, como mostram as figuras dadas. Os quadrados $A B C D$ e EFGH têm lado respectivamente iguais a $3 \mathrm{~cm}$ e $9 \mathrm{~cm}$. Determine a medida do lado do quadrado IJKL.
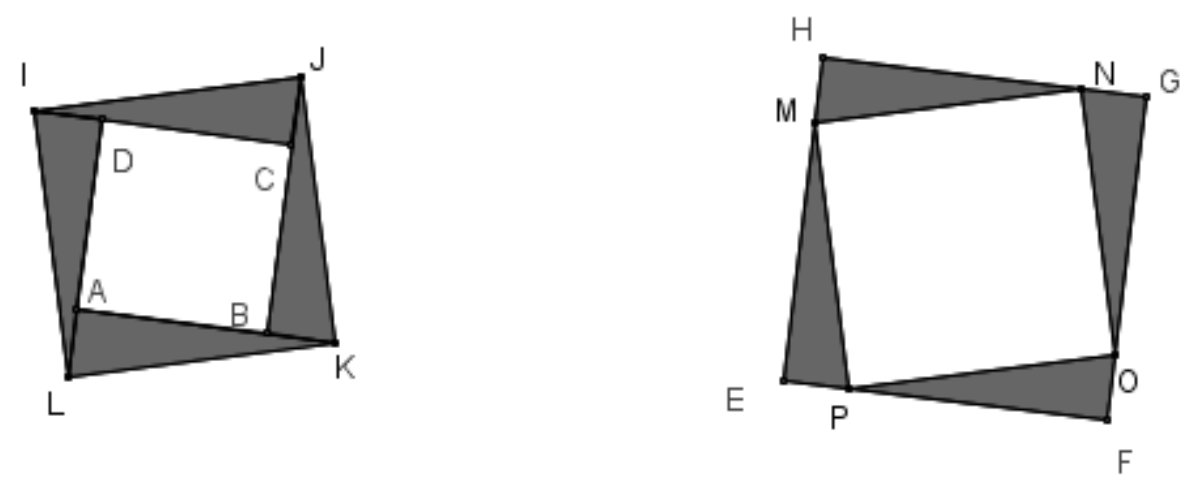

Figura 1: Atividade Inicial - Fase 1 - Etapa 1

${ }^{15}$ Fonte: www.obmep.org.br/bq/bancoobmep2010.pdf. Último acesso em: 20 out. 2014. 
$\mathrm{Na}$ primeira questão, o enunciado é dado em língua natural, com dados numéricos. É possível que os alunos realizem uma conversão desse registro para o registro figural, primeiramente, e espera-se que apliquem diretamente o Teorema de Pitágoras, uma vez identificados os elementos do triângulo retângulo. Assim, observamos uma nova conversão, dessa vez, para o registro algébrico.

É esperado que a Questão 2 tome mais tempo deles e exija a mobilização de outros tipos de conhecimento, já que, para se chegar à resposta, não basta apenas aplicar uma regra conhecida. Primeiro porque, apesar de o triângulo retângulo aparecer novamente, as suas medidas (catetos ou hipotenusa) não são dadas diretamente. Eles devem atentar ao fato de que o valor de $3 \mathrm{~cm}$ dado para a medida do lado do quadrado $A B C D$ não é a medida de um dos catetos do triângulo em questão. Além disso, devem notar que, como os triângulos que aparecem na figura são congruentes, a medida do cateto $C J$ do triângulo $C / J$, por exemplo, compõe o cateto $B J$ do triângulo $B J K$, pois $B J=B C+C J$.

No banco de questões da OBMEP, temos a proposta de duas soluções para essa questão: a primeira requer, além da conversão para o registro algébrico, uma apreensão perceptiva, pois o aluno deve identificar quais são os catetos e a hipotenusa do triângulo retângulo, na primeira figura, para reconhecê-los, fazendo a correspondência, na segunda figura, como mostra a figura abaixo:

Solução 1: sejam x e y o maior e o menor catetos, respectivamente, do triângulo retângulo. Como o lado do quadrado $A B C D$ mede $3 \mathrm{~cm}$, temos $x-y=3$. Por outro lado, como o lado de EFGH mede 9 $\mathrm{cm}$, temos $x+y=9$. Resolvendo o sistema, encontramos $x=6 y=3$. Logo, o lado do quadrado IJKL, que é a hipotenusa do triângulo retângulo, mede $\sqrt{6^{2}+3^{2}}=\sqrt{45}=3 \sqrt{5} \mathrm{~cm}$, pelo Teorema de Pitágoras.
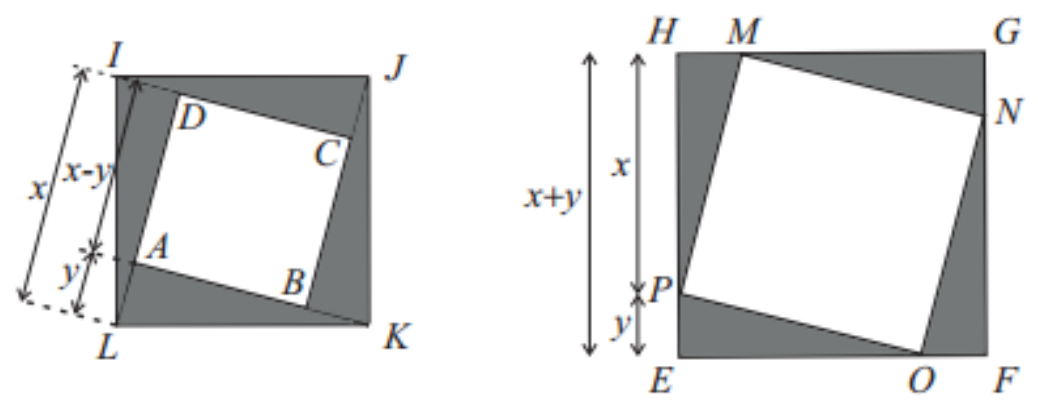

Figura 2: Solução 1, Questão 2, Atividade Inicial - Fase 1 - Etapa 1 Fonte: Banco de questões OBMEP (2010) 
A segunda solução envolve uma apreensão operatória das figuras e, ainda, a atividade de reconfiguração, conforme descrito abaixo. Nesse caso, a resolução demanda visualização no sentido dado por Duval, a saber articulação entre apreensão operatória e perceptiva.

Solução 2: Os quadrados IJKL e MNOP têm como lados as hipotenusas dos triângulos retângulos dados, logo têm a mesma área.

Superpondo-se as duas figuras e fazendo esses dois quadrados coincidirem, encontramos oito triângulos e concluímos que $8 \times$ a área do triângulo é igual à área de EFGH menos a área de $A B C D$, ou seja, é igual a $9^{2}-3^{2}=72$. Logo, a área de cada triângulo é $9 \mathrm{~cm}^{2}$. Da figura, temos que a área de IJKL é igual a $4 \times$ a área do triângulo mais a área de ABCD, ou seja, é igual a $4 \times 9+9=45$.

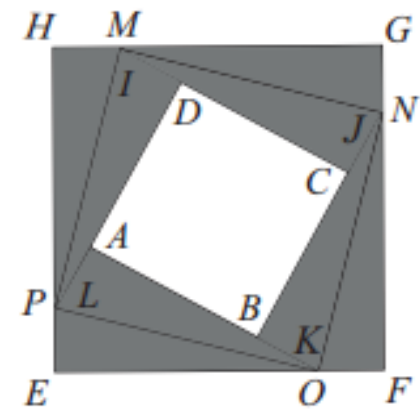

Logo, o lado do quadrado IJKL mede $\sqrt{45}=3 \sqrt{5} \mathrm{~cm}$.

Figura 3: Solução 2, Questão 2, Atividade Inicial - Fase 1 - Etapa 1

Fonte: Banco de questões OBMEP (2010)

Após a finalização da Atividade Inicial, as questões são discutidas, com toda a turma, com os devidos apontamentos acerca das diferenças encontradas no processo de obtenção das soluções. Essa discussão sempre se baseia nas resoluções ou tentativas de resolução dos alunos, de forma a construir a solução a partir de ideias dadas por eles.

É importante que eles percebam principalmente que, na primeira questão, a solução é encontrada diretamente pela aplicação de uma regra, no caso o Teorema de Pitágoras; e, na segunda, não há a possibilidade de aplicação direta da mesma, ou qualquer outra regra.

Em seguida, o Questionário Inicial (Figura 4) é aplicado, para que os alunos respondam individualmente. O questionário nos auxilia na obtenção de informações que possam não ter ficado claras na primeira atividade, sobre suas relações com a Matemática e com a Resolução de Problemas.

Como última parte desta etapa, o Rali Matemático é apresentado aos alunos como um modelo de competição internacional do qual eles participariam enfrentando 
as outras turmas de $1^{\circ}$ ano da mesma escola, salientando a discussão feita anteriormente sobre o que é um problema, de acordo com os tipos de situações trazidos pelo Rali.

\section{QUESTIONÁRIO}

1. Você gosta de Matemática? ( ) SIM ( ) NÃO Por quê?

2. Você se considera um bom aluno em Matemática? ( ) SIM ( ) NÃO Por quê?

3. Para você, o que é um problema de Matemática?

4. Você resolve problemas ou desafios nas aulas de Matemática? ( ) SIM （）NÃO

5. Você resolve problemas ou desafios fora das aulas de Matemática? ( ) SIM ( ) NÃO Quais?

6. Você gosta de resolver problemas ou desafios de Matemática? ( ) SIM ( ) NÃO Por quê?

Figura 4: Questionário Inicial - Fase 1 - Etapa 1

\subsubsection{Fase 1 - Etapa 2}

Na Etapa 2, iniciamos com a aplicação da Prova I, cuja execução se apoia nas regras do Rali Matemático. No entanto, reduzimos o número de problemas visando adequar ao tempo disponível para o experimento, em particular para uma adequada retomada dos mesmos após as provas.

Abaixo, apresentamos os problemas da maneira como foram propostos aos alunos, seguidos de suas análises a priori ${ }^{16}$ e de considerações sobre o que é esperado em relação aos registros de representação semiótica passíveis de serem utilizados nas resoluções.

\footnotetext{
${ }^{16}$ Todos os problemas e análises a priori fazem parte do material organizado pela Associação Rali Matemático Transalpino.
} 


\section{TEMPOS DE COLHEITA DE UVA}

Nas vinhas do Senhor Bruno, num dia de colheita de uva, com toda uva colhida, enchem-se 18 tanques grandes e 13 tanques médios. Para os transportar para a adega, o Senhor Bruno dispõe de três tratores:

- o trator A pode transportar, completamente carregado, 3 tanques grandes e 2 médios;

- o trator B pode transportar, completamente carregado, 2 tanques grandes e 1 médio;

- o trator $\mathrm{C}$ pode transportar, completamente carregado, 1 tanque grande e 1 médio;

Um dia, Senhor Bruno utilizou pelo menos uma vez todos esses tratores e sempre completamente carregados.

Quantas viagens o Senhor Bruno pode ter feito com cada um desses tratores para transportar todos os tanques para a adega?

Descrevam todas as viagens possíveis e expliquem como vocês as encontraram.

Figura 5: Problema 1, Prova I - 14ํRMT, 2006

Fonte: http://www.armtint.org/, tradução nossa.

\section{ANÁLISE A PRIORI}

\section{Domínio de conhecimento}

- Lógica: capacidade de gerar várias condições e organizar tentativas, formulação de hipóteses, raciocínio dedutivo;

- Aritmética: as quatro operações.

- Álgebra: equações e sistemas de equações.

\section{Análise da tarefa}

- Proceder, de maneira organizada, por uma tabela que representa as características de cada trator e do número de tanques transportados aumentando com o número de viagens. Começar, por exemplo, escolhendo o número máximo de viagens do trator $\mathrm{A}$ e o mínimo para $\mathrm{B}$ e $\mathrm{C}$. Perceber que se $B$ e $C$ fazem apenas uma única viagem, $A$ deverá fazer 5 , mas assim, temse transportados 18 tanques grandes e 12 médios, o que não é suficiente.

Supondo que A só faça 4 viagens $(12 ; 8)$ e B uma somente $(2 ; 1)$, chega-se a 14 tanques grandes e 9 médios e é fácil ver que 4 viagens de $C$ bastarão para transportar todos os outros tanques. Obtém-se assim uma primeira solução: 4 viagens para $A, 1$ para $B$ e 4 para $C$.

Supondo que A faça 3 viagens $(9 ; 6)$ e B uma somente $(2 ; 1)$, não é possível terminar com viagens completas de $C$, mas se $B$ faz 2 viagens $(4 ; 1)$, constatase que 5 viagens de $C$ são o complemento e se obtém uma segunda solução: 3 viagens para $A, 2$ para $B$ e 5 para $C$. 
Nas hipóteses em que A faz, respectivamente, 2 ou 1 viagem, encontra-se, da mesma maneira, as duas outras soluções: 2 viagens para $A, 3$ para $B, 6$ para $C$ e 1 viagem para $A, 4$ para $B$ e 7 para $C$.

- Ou: a partir de uma solução encontrada (por tentativas sucessivas), obter as outras observando que uma viagem de $A$ equivale a uma de $B$ e uma de $C$.

- Ou: proceder por álgebra resolvendo um sistema de equações como, por exemplo:

Se $x, y$ e $z$ são, respectivamente, os números de viagens dos tratores $A, B$ e $C$, a situação se traduz por duas equações: $3 x+2 y+z=18$ e $2 x+y+z=13$, em que se tira, por diferença, $x+y=5$ e em que se fixam as soluções em números inteiros diferentes de zero: $(1 ; 4),(2 ; 3),(3 ; 2),(4 ; 2)$. Cada par permite determinar o valor correspondente de $z$ (respectivamente, 7, 6, 5, 4). Encontrase, assim, as quatro possibilidades.

\section{Atribuição de pontos}

4 Resposta correta (as 4 possibilidades: 4 viagens para A, 1 para B e 4 para C; 3 viagens para $A, 2$ para $B$ e 5 para $C ; 2$ viagens para $A, 3$ para $B$ e 6 para $C ; 1$ viagem para $A, 4$ para $B$ e 7 para $C$ ) bem argumentada.

3 Descoberta de três possibilidades corretas com justificativas.

2 Descoberta de duas possibilidades corretas com justificativa ou três corretas e uma ou várias erradas.

1 Somente uma possiblidade e/ou tentativas ou raciocínios que atestam uma compreensão inicial do problema.

0 Incompreensão do problema

O enunciado é dado em língua natural, com alguns dados numéricos. Uma das possíveis soluções pode ser obtida por meio de um registro numérico tabular, como, no exemplo a seguir. A utilização da tabela, em termos de registro de representação, caracteriza uma conversão do registro da língua natural do enunciado para o numérico tabular.

Nesta tabela (Tabela 2), consideramos o número máximo de viagens possíveis para o trator A, pensando no fato de que cada trator precisa fazer, pelo menos, uma viagem. 


\begin{tabular}{|c|c|c|c|}
\hline TRATOR A & TRATOR B & TRATOR C & TOTAL \\
\hline \multirow{7}{*}{1 viagem: $(3,2)$} & 1 viagem: $(2,1)$ & 13 viagens: $(13,13)$ & $(18,16)$ \\
\hline & 2 viagens: $(4,2)$ & 11 viagens: $(11,11)$ & $(18,15)$ \\
\hline & 3 viagens: $(6,3)$ & 9 viagens: $(9,9)$ & $(18,14)$ \\
\hline & 4 viagens: $(8,4)$ & 7 viagens: $(7,7)$ & $(18,13)$ \\
\hline & 5 viagens: $(10,5)$ & 5 viagens: $(5,5)$ & $(18,12)$ \\
\hline & 6 viagens: $(12,6)$ & 3 viagens: $(3,3)$ & $(18,11)$ \\
\hline & 7 viagens: $(14,7)$ & 1 viagem: $(1,1)$ & $(18,10)$ \\
\hline \multirow{5}{*}{2 viagens: $(6,4)$} & 1 viagem: $(2,1)$ & 10 viagens: $(10,10)$ & $(18,15)$ \\
\hline & 2 viagens: $(4,2)$ & 8 viagens: $(8,8)$ & $(18,14)$ \\
\hline & 3 viagens: $(6,3)$ & 6 viagens: $(6,6)$ & $(18,13)$ \\
\hline & 4 viagens: $(8,4)$ & 4 viagens: $(4,4)$ & $(18,12)$ \\
\hline & 5 viagens: $(10,5)$ & 2 viagens: $(2,2)$ & $(18,11)$ \\
\hline \multirow{4}{*}{3 viagens: $(9,6)$} & 1 viagem: $(2,1)$ & 7 viagens: $(7,7)$ & $(18,14)$ \\
\hline & 2 viagens: $(4,2)$ & 5 viagens: $(5,5)$ & $(18,13)$ \\
\hline & 3 viagens: $(6,3)$ & 3 viagens: $(3,3)$ & $(18,12)$ \\
\hline & 4 viagens: $(8,4)$ & 1 viagem: $(1,1)$ & $(18,11)$ \\
\hline \multirow{2}{*}{4 viagens: $(12,8)$} & 1 viagem: $(2,1)$ & 4 viagens: $(4,4)$ & $(18,13)$ \\
\hline & 2 viagens: $(4,2)$ & 2 viagens: $(2,2)$ & $(18,12)$ \\
\hline 5 viagens: $(15,10)$ & 1 viagem: $(2,1)$ & 1 viagem: $(1,1)$ & $(18,12)$ \\
\hline
\end{tabular}

Tabela 2: Solução Problema 1, Prova I - Fase 1 - Etapa 2

Assim, para cada quantidade de viagens do trator $A$, consideramos o número máximo de viagens possíveis para $\mathrm{B}$ e, por fim, o número de viagens que o trator $\mathrm{C}$ deve fazer para que todos os tanques sejam transportados.

A produção de tal registro requer uma interpretação dos dados contidos no enunciado, em língua natural, que examine o número de tanques transportados de acordo com o número de viagens feitas por cada trator. Dessa forma, percebemos que a conversão não é congruente. De fato, há uma interdependência entre os dados de cada coluna e não se trata de uma atividade de preenchimento de uma tabela pela identificação direta dos dados numéricos no enunciado do problema. Com isso, fazemos a hipótese de que esse tipo de conversão não seja produzida espontaneamente pelos alunos, razão pela qual, será proposta na Etapa 3 da Fase 1, 
quando da discussão das resoluções. Assim, buscaremos observar se é compreendida pelos alunos e se pode assumir um papel auxiliar nas soluções.

Conforme descrito anteriormente, é possível encontrar a solução por meio de tentativas. Dessa forma, faz-se uma conversão do registro em língua natural do enunciado para o registro numérico, observando o que é necessário para que as condições propostas na situação sejam satisfeitas. É uma maneira de se chegar à solução que nem sempre ocorre de forma organizada e, por isso, pode tanto inibir a busca por todas as soluções possíveis, quanto levar o aluno a incorrer em erros de cálculo. É provável que esta seja a estratégia a ser adotada pela maioria dos grupos e, analisaremos seu alcance e como é representada pelos alunos.

Por fim, é um tipo de problema que admite solução algébrica. Nesse caso, a utilização do registro algébrico exige que, após tratamentos nesse registro, uma nova conversão seja feita para o registro numérico. Deve-se observar que a solução do problema é restrita a números inteiros positivos. Portanto, é preciso considerar, no registro numérico, quais somas de números inteiros positivos são iguais a cinco e, ainda, verificar, numericamente, a quantidade de viagens de C. Embora os alunos participantes já tenham sido introduzidos à Álgebra, é provável que não façam uso desse registro.

\section{UMA ESPIRAL PARTICULAR}

Jean tem uma folha de papel quadriculado, sobre a qual os quadrados têm lado de $1 \mathrm{~cm}$. Ele começa a desenhar uma espiral como a que se vê na figura: ele parte de A, se desloca horizontalmente 6 quadrados, depois verticalmente 1 quadrado, depois de novo horizontalmente 7 quadrados, depois verticalmente 2 quadrados, e assim por diante.

Jean para depois do quinquagésimo segmento horizontal.

Quanto mede, em centímetros, a espiral desenhada por Jean?

Expliquem como pensaram para chegar na resposta.

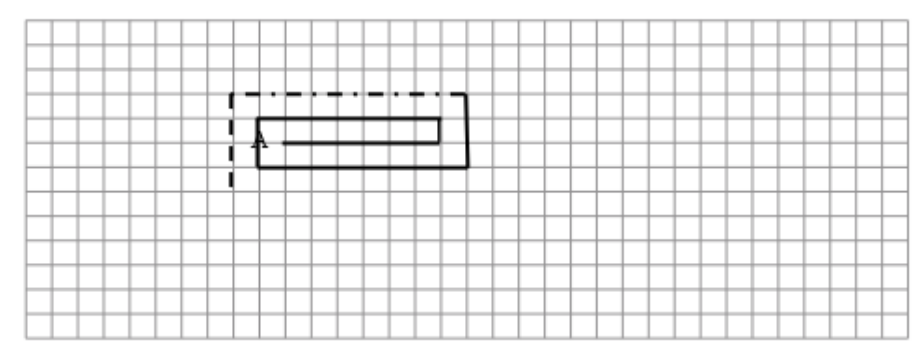

Figura 6: Problema 2, Prova I - 16을 RMT, 2008

Fonte: http://www.armtint.org/, tradução nossa. 


\section{ANÁLISE A PRIORI}

\section{Domínio conceitual}

- Aritmética: soma de números inteiros sucessivos; propriedades de operações.

- Álgebra: abordagem da noção de sequência aritmética.

\section{Análise da tarefa}

- Compreender as regras de construção da espiral e se dar conta de que as medidas dos segmentos, em $\mathrm{cm}$, tanto horizontal, quanto vertical, aumentam cada vez $1 \mathrm{~cm}$.

- Observar que a medida dos segmentos verticais é 1, 2, 3, 4... e a medida dos segmentos horizontais é $6,7,8,9 \ldots$ Constatar que a medida do n-ésimo segmento horizontal é $n+5$ e que, por consequência, o comprimento do quinquagésimo segmento horizontal é $50+5=55 \mathrm{~cm}$, ou, por um raciocínio análogo, $49+6=55$.

- Exprimir o comprimento total da espiral, ou se dar conta de que ela é a soma de duas progressões aritméticas: $(6+7+\ldots+54+55)+(1+2+3+\ldots+48+$ 49) e efetuar as adições numa calculadora (com grande risco de erro, mesmo utilizando a calculadora).

Ou colocar em prática propriedades de operações: comutativa, associativa e distributiva, que permitem simplificar os cálculos reagrupando termos ou transformando somas em produtos. Por exemplo: associando dois termos de cada sequência (a partir do início e do fim) para obter somas parciais constantes: $(6+7+\ldots+54+55)+(1+2+\ldots+48+49)=(6+55)+(7+54)$ $+\ldots+(1+48)+(2+47)+\ldots=61 \times 25+49 \times 25=110 \times 25=2750$.

ou reagrupando os termos das duas sequencias dois a dois $6+1+7+2+8+$ $3+\ldots+54+49+55=(1+2+3+4+\ldots+49)+(1+2+3+4+\ldots+49)+6$ x $50=2 \times(1+2+3+4+\ldots+49)+6 \times 50$, depois, como anteriormente, por associação e distributividade, chegar a $49 \times 50+6 \times 50=55 \times 50=2750$.

\section{Atribuição de pontos}

4 Resposta correta $(2750 \mathrm{~cm})$ com explicações claras (cálculos detalhados).

3 Resposta correta com explicações pouco claras ou resposta correta com explicações claras e somente um erro de cálculo ou de determinação de comprimento dos últimos segmentos. 
2 Resposta correta sem explicações ou dois erros ou imprecisões.

1 Início de raciocínio correto ou resposta com mais de dois erros.

0 Incompreensão do problema.

O enunciado é apresentado em língua natural e há o registro figural que representa a situação descrita. O processo de solução consiste em observar que os segmentos, horizontais e verticais, aumentam em $1 \mathrm{~cm}$, constatar quais são as medidas dos últimos segmentos e, então obter a soma das medidas de todos os segmentos. Assim, a resolução do problema envolve a conversão do registro em língua natural para o registro numérico, seguindo com o tratamento nesse registro.

Conforme descrito na análise a priori, é possível que se faça a conversão do registro numérico para o algébrico ao observar que o n-ésimo segmento horizontal tem medida $n+5$, o que pode não ser imediato para os alunos. Além disso, também pode ser observado que o comprimento total da espiral é a soma de duas progressões aritméticas se os segmentos horizontais e verticais forem considerados separadamente.

Se os alunos observarem a formação das progressões aritméticas, é possível que tentem fazer uso de uma fórmula que determine o n-ésimo termo da progressão, ou a soma dos termos da progressão.

Ao efetuar a adição de todos os termos para obter o comprimento da espiral, como indicado acima, mesmo que façam uso de uma calculadora, a chance de cometerem erros é grande. Por isso, torna-se interessante a organização das informações do enunciado numa tabela. Tal tabela será proposta e discutida também na Etapa 3, tendo em vista a compreensão das regras de formação da espiral.

Ao produzir a Tabela 3, leva-se em consideração o que é colocado no enunciado: deslocamento horizontal, em seguida, deslocamento vertical. Assim, a tabela é preenchida observando-se o aumento do comprimento de segmentos horizontais e verticais separadamente.

Após preencher algumas linhas da tabela é possível perceber uma relação entre a posição do segmento e seu comprimento. Nesse caso, uma nova conversão pode ser feita: do registro numérico para o registro simbólico algébrico, observando que um segmento horizontal de posição $n$, tem comprimento $n+5$ e um segmento vertical de posição $n$, tem comprimento $n$. 


\begin{tabular}{|c|c|c|}
\hline POSIÇÃO & $\begin{array}{c}\text { COMPRIMENTO } \\
\text { HORIZONTAL }\end{array}$ & COMPRIMENTO VERTICAL \\
\hline $1^{\circ}$ & 6 & 1 \\
\hline $2^{\circ}$ & 7 & 2 \\
\hline $3^{\circ}$ & 8 & 3 \\
\hline $4^{\circ}$ & 9 & 4 \\
\hline $5^{\circ}$ & 10 & $\ldots$ \\
\hline$\ldots$ & $\ldots$ & $n$ \\
\hline n-ésimo & $\mathrm{n}+5$ & 5 \\
\hline
\end{tabular}

Tabela 3: Solução Problema 2, Prova I - Fase 1 - Etapa 2

A partir dessa generalização, deve-se determinar a medida do quinquagésimo segmento horizontal e ainda é preciso observar que o último segmento vertical a ser considerado é o quadragésimo nono. Com isso, o comprimento total da espiral pode ser determinado procedendo com o tratamento no registro numérico.

Embora o preenchimento da tabela tenha correspondência direta com o que é descrito no enunciado e na figura, não é esperado que os alunos a produzam espontaneamente. Talvez eles não considerem segmentos horizontais e verticais separadamente, efetuando a soma dos comprimentos de segmentos consecutivos (1 $+6+2+7+3+8+\ldots)$. Dessa forma, há ainda mais possibilidades de ocorrência de erros devido ao grande número de parcelas e da dificuldade em se estabelecer relações entre elas nessa ordem.

\section{A VARANDA DE JOSÉ}

José tem uma varanda quadrada de $10 \mathrm{~m}$ de lado.

Ele deseja pintar o chão de branco e cinza.

Fez um esboço para seu projeto, traçando um quadrado que representa a varanda e, no seu interior, quatro segmentos de reta que ligam cada vértice ao ponto médio de um lado oposto.

Pintou de cinza quatro partes e deixou as outras cinco em branco. 


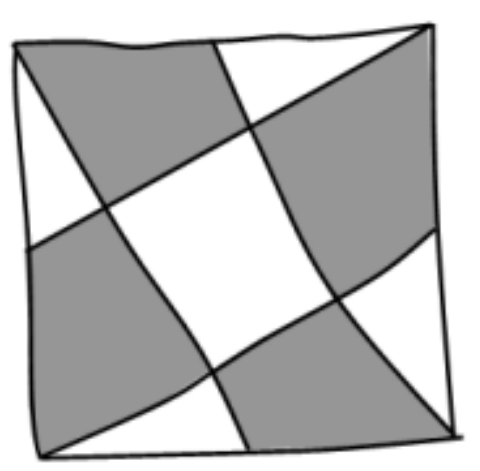

José observa seu esboço e se pergunta de qual formato serão as diferentes partes e se a área de todas as partes brancas será a mesma das partes cinzas juntas.

Calculem a área total das partes brancas e a das partes cinzas, dando detalhes de como pensaram e dos cálculos realizados.

Figura 7: Problema 3, Prova I - 22은 RMT, 2014

Fonte: http://www.armtint.org/, tradução nossa.

\section{ANÁLISE A PRIORI}

\section{Tarefa Matemática}

Um quadrado de $10 \mathrm{~m}$ de lado é dividido em nove partes por quatro segmentos ligando um dos quatro vértices a um dos quatro pontos médios dos lados. Determinar a área das partes de cada cor, após ter percebido a forma que elas têm.

\section{Análise da Tarefa}

- Observar o desenho, constatar que a figura se decompõe em nove partes e dar-se conta de que é preciso determinar a forma de cada uma das partes antes de entrar na fase do cálculo de áreas.

- Esta determinação pode ser feita visualmente (perceptivamente), mas deve ser confirmada de alguma forma: com instrumentos de desenho geométrico ou com uso de papel quadriculado; ou ainda produzindo uma argumentação, deduzida das propriedades do quadrado e de seus lados divididos em duas partes congruentes (medidas iguais) pelo ponto médio.

- As nove partes (figura 1) são: um quadrado central, quatro trapézios retângulos iguais e quatro triângulos retângulos iguais. É possível identificar também quatro "grandes" triângulos (figura 2, composto de um trapézio e de dois "pequenos" triângulos), quatro triângulos "médios" (figura 3 composta de um trapézio e de um "pequeno" triângulo). Os grandes triângulos são quartos do 
grande quadrado (medidas dos lados do ângulo reto 5 e $10 \mathrm{~cm}$, área $25 \mathrm{~cm}^{2}$, hipotenusa $\sqrt{125}$ ou $5 \sqrt{5} \mathrm{~cm}$ ). Todos os triângulos da figura são semelhantes (mesmos ângulos e razão 2 entre as medidas dos catetos) ...

- Para o cálculo das áreas, vários procedimentos são possíveis:

Por medida de comprimentos e cálculos das áreas sobre uma figura construída precisamente em escala, a partir de um quadrado de lado $10 \mathrm{~cm}$.

Por meio de uma malha quadriculada (construção precisa em papel quadriculado de um quadrado de 10 unidades de lado, figura 4): a contagem dos quadrados do triângulo que é a metade de um retângulo $2 \times 5$ permite obter a área: 5 (em unidades da malha), depois a área de todas as outras figuras.

Por "pavimentação" do quadrado em pequenos triângulos. Para isso, deve-se observar que os quatro triângulos pequenos (cuja hipotenusa mede $5 \mathrm{~cm}$ ) podem ser colocados sobre todos os lados do quadrado (figura 5), depois, que os retângulos são compostos por dois desses triângulos (figura 6) e, finalmente, que o quadrado central se decompõe em quatro desses triângulos (figura 7). As áreas das diferentes partes podem ser expressas em "pequenos triângulos" (12 para as partes cinzas e 8 para as partes brancas) ou em $\mathrm{m}^{2}$ após conversão de unidade (60 e 40).

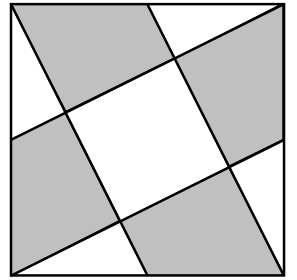

Figura 1

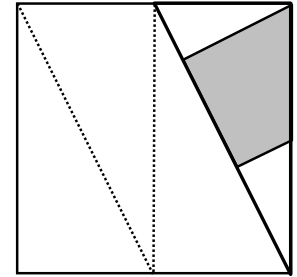

Figura 2

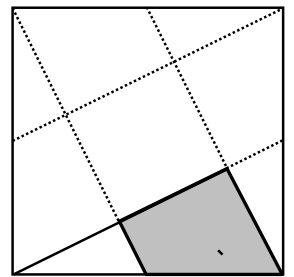

Figura 3

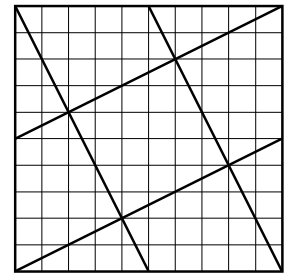

Figura 4

Por decomposição e recomposição, observando, por exemplo, que um trapézio e um triângulo podem ser combinados para formar um quadrado equivalente ao quadrado central (eventualmente por uma rotação de triângulos, ver figura 8), depois deduzindo que a varanda quadrada pode ser decomposta em 5 partes equivalentes ao quadrado central, de 100:5 $=20\left(\mathrm{~m}^{2}\right)$. Em seguida, que a área de um triângulo é $5 \mathrm{~m}^{2}$ e que a área de um trapézio é de $15 \mathrm{~m}^{2}$, para chegar, finalmente, à área da parte cinza: $4 \times 15=60$, em m², e a área da parte branca, $40 \mathrm{~m}^{2}$. 


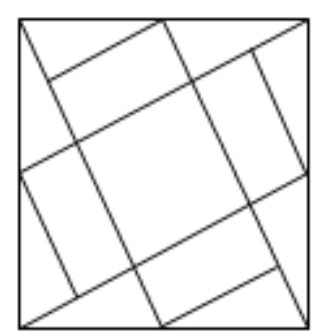

Figura 5

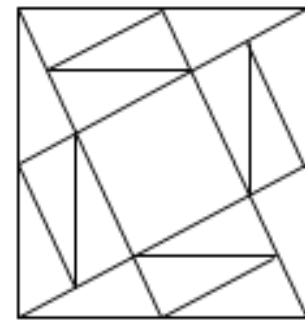

Figura 6

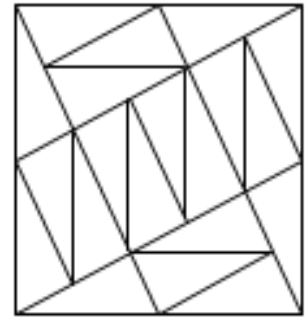

Figura 7

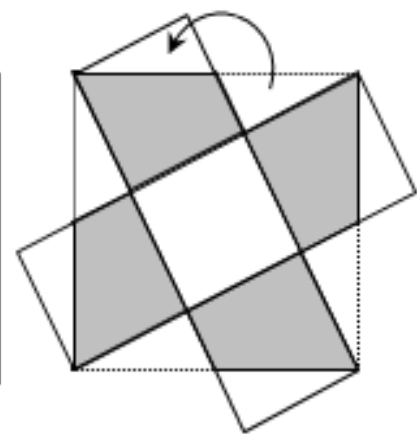

Figura 8

Por via algébrica, designando por $\mathrm{x}$ e $2 \mathrm{x}$ as medidas dos lados do ângulo reto de um triângulo pequeno, em que a hipotenusa mede 5 (em $\mathrm{m}$ ), utilizar $\mathrm{x}^{2}+4 \mathrm{x}^{2}$ $=25$ (Pitágoras), depois $5 x^{2}=25$ e, finalmente, $x^{2}=5\left(e m m^{2}\right)$ que é também a área dos triângulos $(\mathrm{x} .2 \mathrm{x}) / 2=\mathrm{x}^{2}$.

\section{Atribuição de pontos}

4 Resposta correta completa (cinzas: $60 \mathrm{~m}^{2}$ e brancos: $40 \mathrm{~m}^{2}$ ) com explicações completas das operações efetuadas de maneira que as figuras sejam reconhecidas (construção precisa, quadrado, triângulos e trapézios nomeados, ou outra menção explícita da reflexão sobre as formas).

3 Resposta correta completa $\left(60 \mathrm{~m}^{2}\right.$ e $\left.40 \mathrm{~m}^{2}\right)$ com detalhes da pesquisa das áreas (por pavimentação, decomposição, álgebra, medida sobre o desenho, malha quadriculada etc.) mas sem qualquer menção da reflexão sobre as figuras.

2 Resposta correta completa $\left(60 \mathrm{~m}^{2}\right.$ e $\left.40 \mathrm{~m}^{2}\right)$ sem explicações ou resposta próxima de $60 \mathrm{~m}^{2}$ e $40 \mathrm{~m}^{2}$, em que os cálculos de área foram efetuados a partir de medidas aproximadas de um desenho ou resposta completa e bem explicada, mas falso por causa de erro de cálculo.

1 Início de raciocínio correto, por exemplo, cálculo da área de uma das partes somente (20 $\mathrm{m}^{2}$ para o quadrado, $5 \mathrm{~m}^{2}$ para um triângulo pequeno) com explicações.

0 Incompreensão do problema.

O enunciado do problema é dado no registro em língua natural e figural. A solução do problema requer visualização, uma vez que a articulação entre a apreensão operatória e a apreensão perceptiva é necessária. A operação de reconfiguração é essencial, pois, após a identificação das partes que formam a figura, elas podem ser decompostas e reagrupadas de diferentes maneiras. 
Ao identificar as partes em uma malha quadriculada, os alunos poderão utilizar medidas e, numa conversão do registro figural para o registro numérico, calcular as áreas de cada figura. Nesse momento, há a possibilidade de se recorrer ao registro algébrico simbólico ao utilizar, por exemplo, o Teorema de Pitágoras para calcular a medidas dos lados do triângulo menor da figura. Para isso, é preciso que os alunos identifiquem a relação entre as medidas dos dois catetos, fazendo a conversão do registro figural para o registro algébrico.

Como estão familiarizados com o cálculo de áreas por meio de fórmulas, é possível o que tentem fazer. Porém, tenham dificuldade em identificar as medidas que devem ser utilizadas nessas fórmulas, uma vez que elas não estão dadas explicitamente. Pelo mesmo motivo, o cálculo da área utilizando o quadrado da malha como unidade de medida, na maneira como é proposto na análise a priori, pode não ser imediato para os alunos.

A apreensão operatória é essencial e tem grande importância no processo de resolução desse e de outros problemas, porém é possível que os alunos não estejam habituados a esse tipo de atividade. A partir da reconfiguração é possível identificar partes que têm áreas equivalentes, por exemplo, a figura pode ser subdividida em triângulos congruentes; ou ainda pode-se recorrer a outro tipo de operação para modificação da figura, combinando um triângulo com um trapézio para a formação de quadrados de mesma área.

Assim, reconhecendo o papel decisivo da apreensão operatória para a utilização heurística de figuras, a solução que utiliza reconfiguração terá destaque no momento da discussão das soluções na Etapa 3.

\subsubsection{Fase 1 - Etapa 3}

A última etapa desta fase tem o objetivo de colocar em discussão a solução dos problemas da Prova I. Para isso, buscamos nos basear nas ideias dos próprios alunos e coordená-las com as possíveis maneiras de representar as situações propostas, de acordo com o exposto na seção anterior. 
Considerando que nem sempre os alunos teriam disponíveis as ideias para se concluir uma resolução, preparamo-nos para fornecer elementos através de questionamentos. Por exemplo:

- Problema I: Existe um número máximo de viagens possíveis para cada trator?

- Problema II: De que maneira a medida dos segmentos está aumentando?

- Problema III: Quais formas geométricas formam a figura? Como podemos confirmar isso?

É importante ressaltar que não se trata de corrigir, ou expor as repostas para os problemas, mas permitir que os participantes expressem suas ideias e, a partir da análise e da discussão com a turma, chegar a um consenso sobre o resultado correto, conforme a organização proposta por Allevato e Onuchic (2009).

\subsubsection{Descrição da Fase 2}

\subsubsection{Fase 2 - Etapa 1}

A Etapa 1 da segunda fase consiste na aplicação de três problemas, que permitem representações semelhantes às abordadas no encontro anterior. No entanto, os dois primeiros problemas são modificados de modo que, para solucionálos, os alunos devem realizar um procedimento específico indicado no enunciado. Tal procedimento é baseado em uma das representações possíveis para a resolução do problema.

No problema de Geometria dessa etapa - assim como das outras - a operação de reconfiguração tem papel fundamental na produtividade heurística das figuras. Por esse motivo, a indicação de uma operação a ser realizada para a resolução anularia qualquer pesquisa prévia a ser empregada. Assim, apenas para o problema de Geometria não é sugerido um procedimento a ser efetuado pelos alunos.

A seguir, mostramos as questões propostas já adaptadas e suas respectivas análises a priori. 


\section{DIA DE CHUVA}

Toda semana, Max e Leonardo compram na banca o último número da Super Legal, a revista preferida deles, e uma "coletânea" que inclui 5 edições antigas juntas.

Numa tarde de chuva, Max lê a última edição publicada, a 5802, e Leonardo, a coletânea das edições antigas, 4506, 4507, 4508, 4509 e 4510, que acabou de ser publicada.

Num certo momento, Leonardo pergunta: "Em breve não haverá mais coletâneas porque elas alcançarão o último número da Super Legal! O que eu vou ler então?"

Max responde: "Você tem razão! Eu nunca tinha pensado nisso, mas não se preocupe, isso vai demorar muitas semanas para acontecer, até lá a chuva terá parado!"

Em quantas semanas as "coletâneas" de números antigos coincidirão com o novo número da revista Super Legal?

Para responder, utilize a tabela abaixo. Ao final, justifique sua resposta.

\begin{tabular}{|c|c|c|}
\hline Semana & № da nova revista & Último no da coletânea \\
\hline 0 & 5802 & 4510 \\
\hline 1 & $5802+1$ & $4510+5$ \\
\hline 2 & & \\
\hline 3 & & \\
\hline 4 & & \\
\hline$\cdots$ & & \\
\hline$N$ & & \\
\hline
\end{tabular}

Figura 8: Problema 1, Prova II - 16ำ RMT, 2008

Fonte: http://www.armtint.org/, tradução nossa, adaptado.

\section{ANÁLISE A PRIORI}

\section{Domínio de conhecimento}

- Aritmética

- Álgebra: equações do primeiro grau ou representação gráfica.

\section{Análise da tarefa}

- Resolver o problema por aritmética, calculando a distância entre os números e as coletâneas. Por exemplo: esta semana, a coletânea chegou a 4510, portanto 5802 4510 = 1292 números de "atraso" sobre o número que acaba de ser publicado. Como a coletânea "alcança" 4 números por semana, deve ser 1292:4=323 semanas.

- Verificar que nas 323 semanas, as duas publicações coincidirão no número $6125=$ $4510+5 \times 323=5802+323$.

Ou, por meio de uma tabela que conduz a uma resolução algébrica: 


\begin{tabular}{|c|c|c|c|c|c|}
\hline \multirow[t]{5}{*}{ Semana: } & 0 & Número da revista: & 5802 & Último $n^{\circ}$ da & 4510 \\
\hline & 1 & & $5802+1$ & coletânea: & $4510+5$ \\
\hline & 2 & & $5802+2$ & & $4510+10$ \\
\hline & $\ldots$ & & $\ldots$ & & $\cdots$ \\
\hline & $\mathrm{X}$ & & $5802+x$ & & $4510+5 x$ \\
\hline
\end{tabular}

Resolver a equação $4510+5 x=5802+x$ em que a solução é $x=323$.

Ou representar graficamente as duas equações anteriores por duas retas e encontrar seu ponto de interseção.

\section{Atribuição de pontos}

4 Solução correta $\left(323^{\star}\right)$ com explicação clara do procedimento seguido (aritmético ou algébrico).

3 Solução correta (323) com explicações confusas e incompletas ou explicações coerentes, mas com um erro de cálculo.

2 Solução correta (323) sem explicações ou somente com verificação ou estabelecimento de equações corretas sem solução ou dois erros de cálculo.

1 Início de pesquisa coerente.

0 Incompreensão do problema.

*Aceita-se a resposta 322, se ela é claramente motivada pelas dificuldades materiais de publicar o último número e o inserir na coletânea da mesma semana.

O enunciado é apresentado em língua natural, com dados numéricos e, como foi adaptado, temos, ainda, o registro numérico tabular. A escolha da tabela como sugestão na resolução do problema se justifica pelo fato de esse tipo de representação ter sido discutido nos dois primeiros problemas da Prova I.

A tabela presente no enunciado não é preenchida diretamente: é necessário que se compreenda a relação entre o número da revista e a semana de sua publicação. Assim, podemos dizer que a conversão do registro em língua natural (enunciado) para o registro numérico tabular não é congruente e, portanto, reduz-se a possibilidade de essa tabela ser produzida espontaneamente pelos alunos.

A partir da compreensão sobre a maneira como os números aumentam a cada semana por meio do preenchimento da tabela, uma conversão é necessária do registro numérico para o simbólico algébrico para se escrever o número da revista em função do número de semanas $x$. A solução para o problema é obtida pelo tratamento 
no registro algébrico ao se igualar as duas expressões encontradas. Porém, apesar de conhecerem o registro algébrico, talvez os alunos não perceberam a relação entre o fato de os números das revistas novas e antigas coincidirem (registro em língua natural do enunciado) e as expressões (registro algébrico) " $n^{\circ}$ da revista nova" e "último $n^{\circ}$ da revista antiga" serem iguais.

Sem a conversão para o registro algébrico, é possível chegar à resposta observando, em cada linha, a diferença entre o novo número da revista e o último número antigo. A cada semana, a diferença entre esses números diminuiu 4 unidades. Dessa forma, o processo de solução prossegue no registro numérico, utilizando-se os números obtidos na segunda e terceira coluna da tabela.

\section{CASTELO DE CARTAS}

Andrea se diverte construindo castelos com cartas de baralho. Ela construiu dois castelos: o primeiro tem dois níveis e é feito com 7 cartas; o segundo tem três níveis e é feito com 15 cartas.
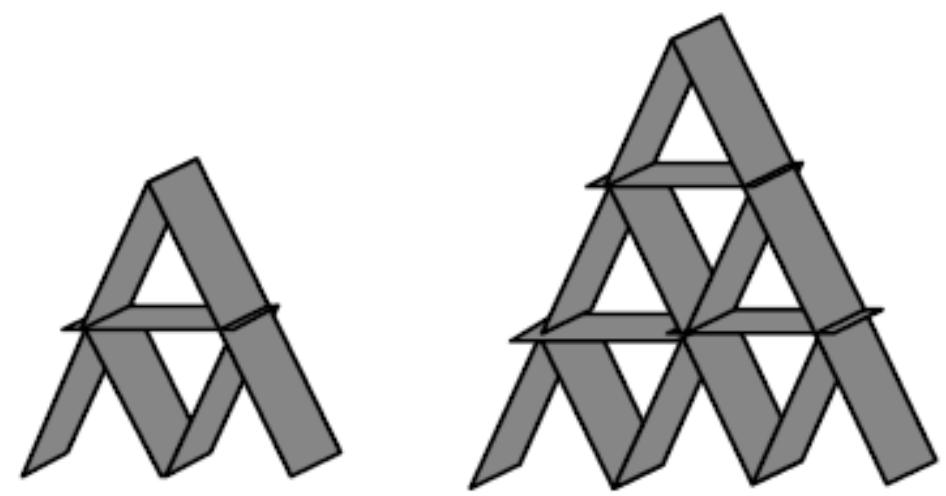

Quantas cartas Andrea vai utilizar para construir um castelo de 25 níveis? Completem a tabela abaixo e, a partir dela, tentem resolver o problema, explicando como chegaram à resposta.

\begin{tabular}{|c|c|c|}
\hline Nível & No de cartas & No de cartas como uma soma \\
\hline 1 & 2 & 2 \\
\hline 2 & 7 & $2+5$ \\
\hline 3 & & \\
\hline 4 & & \\
\hline$\ldots$ & & \\
\hline$P$ & & \\
\hline
\end{tabular}

Figura 9: Problema 2, Prova II - 13ํㅡㄴ, 2005 
Fonte: http://www.armtint.org/, tradução nossa, adaptado.

\section{ANÁLISE A PRIORI}

\section{Domínio de conhecimento}

- Aritmética: adição e multiplicação.

- Lógica: capacidade de dedução e de abstração.

- Álgebra.

\section{Análise da tarefa}

- Compreender a regra de construção dos castelos e compreender como passar de um castelo ao seguinte (com um nível a mais).

- Depois de ter desenhado os primeiros castelos, passar ao registro numérico e estabelecer uma relação entre o número de níveis e o número de cartas:

$\begin{array}{cccccccccccc}\text { Nível } & 1 & 2 & 3 & 4 & 5 & 6 & 7 & 8 & 9 & \ldots & 25 \\ \text { Cartas } & 2 & 7 & 15 & 26 & 40 & 57 & \ldots & \ldots & \ldots & \ldots & \ldots\end{array}$

E compreender que para passar de um castelo ao castelo seguinte, deve ser acrescentado um número de cartas igual à diferença entre os números de cartas dos dois níveis precedentes, aumentado de três:

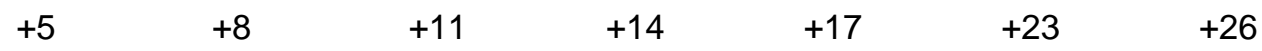

Continuar numericamente até o $25^{\circ}$ nível e escrever todos os resultados intermediários (com o auxílio, eventualmente, de uma calculadora):

$\begin{array}{llllllllllll}\text { Cartas } & 2 & 7 & 15 & 26 & 40 & 57 & 77 & 100 & 126 & \ldots & 950\end{array}$

Ou: procurar uma relação entre o número de níveis e o número de cartas do castelo correspondente. Por exemplo: observar que, no primeiro castelo, o nível 1 (o mais alto) é formado por 3 ( $3 \times 1$ ) cartas (um triângulo completo), enquanto $\circ 2^{\circ}$ nível, o da base, é formado por $4(3 \times 2-2)$ cartas (dois triângulos privados de sua respectiva base); no segundo castelo, o nível 1 é formado por 3 cartas $(3 \times 1$; um triângulo completo), o nível 2 é formado de 6 cartas (3×2; dois triângulos completos), o nível 3 , a base, é formado de 6 cartas ( $3 \times 3-3$; três triângulos sem as bases). Tentar desenhar os castelos mais altos e descobrir que a regra que fornece o número de cartas sobre o plano $n$ é: $3 n$ se $n$ não é o plano de base do castelo, $3 n-n=2 n$ se $n$ é o plano de base do castelo. Chegar assim que, para construir um castelo de $\mathrm{n}$ níveis, é feito $3(1+2+3+\ldots+n)+2 n$ cartas.

Ou ainda: observar que o número de "triângulos" que se pode encontrar em um castelo de $n$ níveis é $n^{2}$ e que, portanto, o número de lados de triângulos é $3 n^{2}$. 
Considerar em seguida que cada lado ao interior do castelo é contado duas vezes e que os triângulos do nível mais baixo não são completos. Concluir que o dobro do número de cartas necessárias para construir um castelo de $n$ planos é dado por $\left(3 n^{2}\right.$ $+2 n-n)$ e, portanto, $\left(3 n^{2}+n\right) / 2$ é o número de cartas necessárias para a construção de um castelo de $n$ níveis.

Ou ainda: observar que para um castelo de $n$ níveis, são usadas $2(1+2+3+\ldots+n)$ cartas oblíquas e $(1+2+3+\ldots+n-1)$ cartas horizontais. Portanto, em tudo, $n(n+1)+n(n-$ 1) $/ 2=\left(3 n^{2}+n\right) / 2$.

- Concluir que para um castelo de 25 níveis, serão necessárias 950 cartas.

\section{Atribuição de pontos}

4 Resposta exata (950) com explicações completas.

3 Resposta correta com explicações pouco claras ou resposta correta com explicações claras e somente um erro de cálculo.

2 Resposta correta sem explicações ou dois erros ou imprecisões.

1 Início de raciocínio correto ou resposta com mais de dois erros.

0 Incompreensão do problema.

No enunciado desse problema, estão presentes o registro em língua natural e figural, além do registro numérico tabular, sugerido na adaptação. $O$ enunciado pede que a tabela seja preenchida para que se obtenha a resposta. Mais uma vez, optouse por esse tipo de representação, por não ser algo que os alunos farão espontaneamente e para que possamos analisar os efeitos dessa indicação no processo de solução.

A resolução do problema requer a compreensão da formação dos castelos a partir da descrição do enunciado, auxiliada pelas figuras. Assim, é possível fazer a conversão do registro figural (caso o aluno opte por desenhar castelos com mais níveis) para o numérico; ou do registro em língua natural para o numérico. Essa conversão não é congruente, pois a tabela deve ser preenchida com o número total de cartas no castelo e a soma das cartas de cada nível. Porém, o enunciado se refere apenas a castelos de dois e três níveis e não mostra a figura de castelos diferentes desses.

Com o preenchimento da tabela sugerida e compreendendo a maneira como a quantidade de cartas aumenta a cada nível, é possível fazer a conversão para o registro algébrico, escrevendo uma expressão que relacione a quantidade de cartas 
no castelo com o número de níveis ( $\mathrm{n}$ ) que ele possui. A maneira como a tabela foi construída privilegia uma das maneiras descritas na análise a priori de se escrever essa relação. No entanto, a conversão pode não ser tão evidente para o aluno, o que mostra a não congruência dessa atividade.

Sem essa conversão, pode-se prosseguir com o registro numérico, escrevendo o número de cartas em cada castelo até um castelo de 25 níveis e, da mesma forma, mas, com a possibilidade de erros na soma, se chega à resposta.

\section{AS MANIAS DOS GRANDES CAMPEÕES}

Um célebre campeão olímpico um dia comprou um grande terreno retangular de 600 metros de comprimento e 500 metros de largura. Ele construiu um centro esportivo retangular de $300 \mathrm{~m}$ por $200 \mathrm{~m}$, de mesmo centro que o terreno, conforme a figura (o comprimento do terreno é paralelo ao comprimento do centro esportivo).

Como tem seis filhos, ele pede em seu testamento que o restante do terreno, em volta do centro esportivo, seja dividido em 6 partes de mesma forma e mesmas dimensões e que o centro esportivo seja acessível diretamente de cada uma das 6 partes.

Desenhem as 6 partes e expliquem como vocês encontraram a resposta.

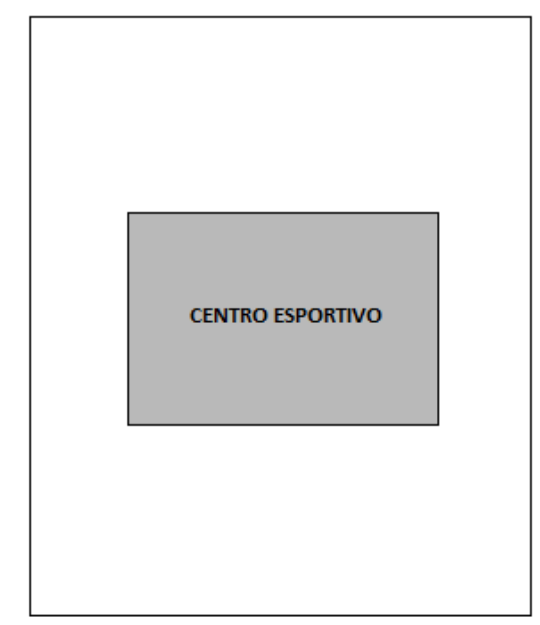

Figura 10: Problema 3, Prova II - 14ํำ 2006

Fonte: http://www.armtint.org/, tradução nossa.

\section{ANÁLISE A PRIORI}

\section{Domínio de conhecimento}

- Geometria: pavimentação, área de um retângulo.

\section{Análise da tarefa}

- Calcular a área da superfície a ser dividida (em m²): 600 × 500 - 300 × $200=240$ 000 e encontrar que a área de cada parcela deverá ser de $40000 \mathrm{~m}^{2}$. 
- Por tentativas sucessivas, se dar conta de que os dois retângulos dados e as diferentes larguras que cercam o retângulo interno exigem a separação por segmentos paralelos aos lados existentes.

- Chegar que a parte a dividir é composta de $6 \times 4=24$ quadrados de $100 \mathrm{~m}$ de lado. As parcelas encontradas têm, então, uma extensão igual a 4 desses quadrados.

- Analisar as formas que podemos construir com 4 quadrados e os arrumar dispondo-os em torno que retângulos central, respeitando a determinação: cada parte deve estar em contato direto com o centro

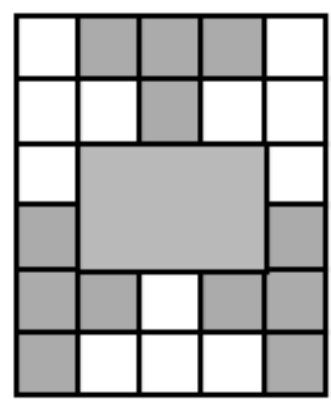
esportivo. Constatar que a forma em T permite resolver convenientemente 0 problema.

\section{Atribuição de pontos}

4 Solução correta e justificativa clara do procedimento.

3 Resposta correta com explicações pouco claras.

2 Resposta correta sem explicações.

1 Início de raciocínio correto ou cálculo da medida da área de cada parte, sem o desenho.

0 Incompreensão do problema.

O enunciado desse problema é em língua natural, com dados numéricos, e há o registro figural. A resposta ao problema é dada pelo desenho da divisão da figura em partes iguais de modo que satisfaçam as condições descritas. Portanto, a atividade de visualização estará presente num processo de conversão do registro em língua natural para o figural.

Com a apreensão perceptiva, é possível notar que, como o retângulo descrito como "centro esportivo" tem o mesmo centro do retângulo maior, as distâncias laterais são iguais. A partir dessa constatação, pode-se iniciar as etapas de divisão da figura.

Por outro lado, como terá sido discutida a subdivisão de uma figura geométrica em quadrados por meio de uma malha quadriculada (Etapa 3 da Fase 1), é possível que os alunos tentem decompor a figura utilizando esse procedimento. 
Ainda que esteja claro, no enunciado, o pedido de se desenhar as partes que cada um recebeu, como há medidas exibidas no texto, é provável que os alunos apenas busquem a solução por meio de cálculos de áreas e não façam o que se pede.

\subsubsection{Fase 2 - Etapa 2}

A Etapa 2 visa retomar os problemas da Prova II. Nos dois primeiros problemas, a representação a ser utilizada é determinada. Então, o início da discussão se dá com a questão do preenchimento das tabelas. Depois, é possível prosseguir com a exposição das ideias dos alunos para se chegar à solução fazendo uso das informações contidas no registro.

$\mathrm{Na}$ Fase 1 os alunos já teriam participado de uma discussão semelhante, portando, nesta etapa, questionamentos podem ser feitos com o intuito de relembrar o que já foi discutido e retomar ideias e estratégias anteriores.

\subsubsection{Descrição da Fase 3}

\subsubsection{Fase 3 - Etapa 1}

$\mathrm{Na}$ fase final, novos problemas são propostos aos alunos, nos quais eles podem utilizar diferentes representações em suas resoluções. Dessa vez, não há indicação do tipo de representação a ser utilizado, como na fase anterior. Assim, podemos observar os efeitos das intervenções na maneira como os alunos resolvem os problemas e se reutilizam espontaneamente as representações trabalhadas em sala de aula. 


\section{MÁQUINA DE TROCO}

Num supermercado da Teenlândia, uma máquina de troco permite trocar notas em moedas do país, que são de seis tipos diferentes: 0,10 TL; 0,20 TL; 0,50 TL; 1 TL; 2 TL; e 5 TL (O "TL" é a moeda local).

Essa máquina dá, para cada nota, apenas moedas cujo produto dos valores seja 1.

Por exemplo:

Com uma nota de 10 TL podemos receber 4 moedas de 0,50 TL e 4 moedas de 2 TL, pois $0,5 \times 0,5$ $\times 0,5 \times 0,5 \times 2 \times 2 \times 2 \times 2=1$;

Ou 2 moedas de 0,50 TL, 2 moedas de 2 TL e 5 moedas de 1 TL ou ...

Graziela e Diana colocaram, cada uma, uma nota de 20 TL e Graziela recebeu 4 moedas a mais que Diana.

Quantas e quais moedas Graziela recebeu? Explique como vocês encontraram a resposta.

Figura 11: Problema 1, Prova III - 16은, 2008

Fonte: http://www.armtint.org/; tradução nossa.

\section{ANÁLISE A PRIOR}

\section{Domínio de conhecimento}

- Aritmética: decomposição de 1 em produto de números decimais.

\section{Análise da tarefa}

- Verificar os exemplos dados.

- Compreender que se trata de encontrar como 1 pode ser decomposto nos números decimais propostos e identificar as três decomposições em fatores: $1=5 \times 2 \times 0,1=5$ $\times 0,2=2 \times 0,5$ e encontrar as três somas correspondentes: $5+2+0,1=7,1 ; 5+0,2$ $=5,2$ e $2+0,5=2,5$.

- Procurar as decomposições aditivas de 20 com os termos 2,5; 5,2; 7,1 e 1.

- Dar-se conta que a única composição aditiva de 20 que envolve os termos 5,2 e 7,1 é: $20=2,5+5,2+5,2+7,1$ (com toda as moedas). Compreender então que todas as outras composições aditivas de 20 contêm apenas os termos 2,5 e/ou 1.

\begin{tabular}{|c|c|c|c|c|c|}
\hline \multicolumn{3}{|c|}{ Moedas (em TL) } & \multirow{2}{*}{ Produto } & Soma & $\begin{array}{c}\text { Número total de } \\
\text { moedas }\end{array}$ \\
\hline 0,5 & $\mathbf{1}$ & $\mathbf{2}$ & & & 20 \\
\hline 0 & 20 & 0 & 1 & 20 & \\
\hline 1 & Imp & 1 & 1 & $2,5+? ?$ & 19 \\
\hline 2 & 15 & 2 & 1 & 20 & \\
\hline 3 & Imp & 3 & 1 & $7,5+? ?$ & 18 \\
\hline 4 & 10 & 4 & 1 & 20 & 17 \\
\hline 6 & 5 & 6 & 1 & 20 & 16 \\
\hline 8 & 0 & 8 & 1 & 20 & \\
\hline
\end{tabular}


- Construir o inventário das decomposições de 20 moedas de 0,5, 1 e/ou 2, nas quais o produto é 1.

Confrontando todas as decomposições de 20TL, se dar conta de que as duas que se diferem em somente 4 moedas são aquelas que utilizam 20 e 16. Graziela recebeu 16 peças: 8 de 0,5 TL e 8 e 1 TL.

Ou prosseguir por tentativa de ver que os únicos pares possíveis são as moedas de 0,5 TL e 2 TL a serem completados pelas moedas de 1 TL.

\section{Atribuição de pontos}

4 Solução exata (Graziela recebeu 16 moedas: 8 de 0,5 e 8 de 2 TL) e explicações (inventário detalhado de todas as decomposições possíveis) o que demonstra a unicidade da solução.

3 Solução exata, com explicações parciais (falta de unicidade).

2 Solução exata sem explicações (encontrada apenas por tentativas).

1 Pesquisa que mostra a compreensão do produto 1.

0 Incompreensão do problema.

O enunciado do problema é apresentado no registro em língua natural, com dados numéricos. O registro numérico aparece no trecho que exemplifica o fato de 0 produto dos valores das moedas obtidas ser igual a 1 e a solução do problema se inicia com a compreensão desse exemplo.

Todo o processo de solução envolve o tratamento no registro numérico, sendo necessário o conhecimento do tratamento dos números em suas expressões decimais. Como se trata de determinar as possibilidades de adições dos valores das moedas que resultem em 20 e cujo produto seja 1, é interessante que se tenha uma organização desses dados.

$\mathrm{Na}$ analise a priori, vemos o exemplo de uma tabela que auxilia a organização das possiblidades, no entanto, essa tabela é obtida a partir de constatações a respeito da decomposição do número 20. Sendo assim, a conversão do registro língua natural, para o registro numérico tabular não é uma atividade congruente.

É provável que os alunos tentem organizar os dados em uma tabela, pois terá sido uma representação de destaque nas discussões em fases anteriores. Porém, a produção de uma tabela que descreva a situação não é imediata, o que pode motivar a busca por outro tipo de representação. 
Assim, poderemos observar uma tendência em buscar a solução por meio de tentativas. Tal procedimento ainda envolve o tratamento no registro numérico, mas não garante a unicidade da solução e pode desmotivar os alunos na conclusão da resolução.

Rali Matemático

PROVA III

(C)ARMT

\section{AS PIRÂMIDES DE FELIPE}

Felipe quer montar pirâmides com diversas camadas. Começou construindo as camadas a partir de um pequeno cubo cinza, cercando-o alternadamente com uma borda de cubos brancos, depois com uma borda de cubos cinzas. Vejam na figura abaixo.
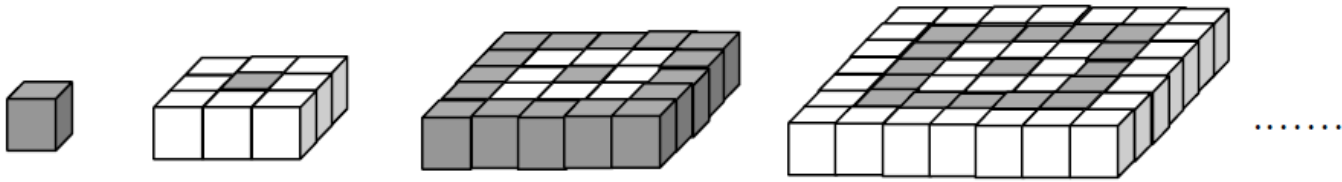

Com um cubo cinza e a primeira camada, ele constrói uma pirâmide de dois andares. Com o primeiro cubo cinza e as duas primeiras camadas, ele constrói uma pirâmide de três andares. A figura abaixo mostra uma pirâmide de quatro andares.

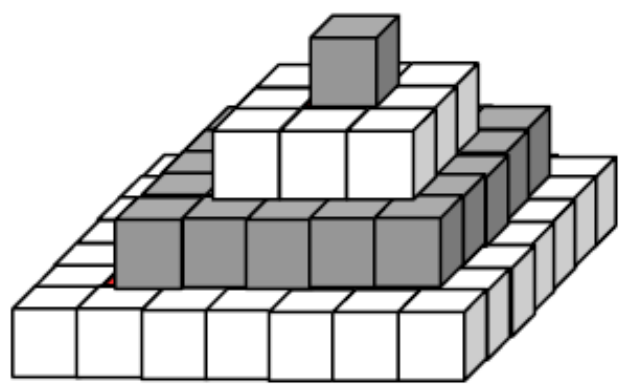

Felipe percebe que para construir essa pirâmide, ele utilizou mais cubos brancos que cubos cinzas. Ele se pergunta o que aconteceria em uma pirâmide de cinco andares e em uma pirâmide de onze andares.

Para cada um desses dois casos, vocês devem calcular a diferença entre o número de cubos de cada cor. Expliquem como pensaram para chegar à resposta.

Figura 12: Problema 2, Prova III - 13은 RMT, 2005

Fonte: http://www.armtint.org/, tradução nossa.

\section{ANÁLISE A PRIORI}

\section{Domínio de conhecimento}

- Aritmética: adição, multiplicação, regularidade de sequências de números

- Geometria: visão espacial, regularidade das construções

- Álgebra

\section{Análise da tarefa}


- Considerar o número de cubos brancos e cinzas por andar e construir a seguinte tabela:

\begin{tabular}{|c|c|c|c|c|c|c|c|c|c|}
\hline Andares & $\mathbf{1}$ & $\mathbf{2}$ & $\mathbf{3}$ & $\mathbf{4}$ & $\mathbf{5}$ & $\mathbf{6}$ & $\mathbf{7}$ & $\mathbf{\ldots}$ & $\mathbf{N}(\mathbf{p a r})$ \\
\hline Cinzas & 1 & 1 & $\begin{array}{c}17 \\
(1+16)\end{array}$ & 17 & $\begin{array}{c}49 \\
(1+16+32)\end{array}$ & 49 & $\begin{array}{c}97 \\
(1+16+32+48)\end{array}$ & $\ldots$ & $1+2 \mathrm{n}(\mathrm{n}-2)$ \\
\hline Brancos & 0 & 8 & 8 & $\begin{array}{c}32 \\
(8+24)\end{array}$ & 32 & $\begin{array}{c}72 \\
(8+24+40)\end{array}$ & 72 & $\ldots$ & $2 \mathrm{n}^{2}$ \\
\hline Total & 1 & 9 & 25 & 49 & 81 & 121 & 169 & $\ldots$ & $(2 \mathrm{n}-1)^{2}$ \\
\hline
\end{tabular}

Portanto, considerar as pirâmides, adicionando os resultados precedentes, obtém-se os seguintes:

\begin{tabular}{|c|c|c|c|c|c|c|c|c|c|}
\hline Andares & $\mathbf{1}$ & $\mathbf{2}$ & $\mathbf{3}$ & $\mathbf{4}$ & $\mathbf{5}$ & $\mathbf{6}$ & $\mathbf{\ldots}$ & $\mathbf{N}$ (par) & $\begin{array}{c}\mathbf{N} \\
\text { (ímpar) }\end{array}$ \\
\hline Cinzas & 1 & 2 & 19 & 36 & 85 & 134 & $\ldots$ & & \\
\hline Brancos & 0 & 8 & 16 & 48 & 80 & 152 & $\ldots$ & & \\
\hline C- B & 1 & -6 & 3 & -12 & 5 & 18 & $\ldots$ & $-3 n$ & $\mathrm{~N}$ \\
\hline
\end{tabular}

Concluir que numa pirâmide de 5 andares, a diferença $\mathrm{C}-\mathrm{B}$ é 5 e em uma de 11 andares, a diferença é 11.

Ou: encontrar o mesmo resultado trabalhando "verticalmente" na pirâmide: uma pirâmide tem $n$ andares e no centro $n$ cubos cinzas, com $8(n-1)$ cubos brancos ao redor, com $16(n-2)$ cubos cinza ao redor, com 24(n-3) cubos brancos ao redor, etc.

Ou: se dar conta de que, sem contar a coluna central de cubos cinzas, nos diversos andares, teremos a seguinte distribuição:

$\begin{array}{lllll}\text { Primeiro andar } & \text { Brancos } 0 & \text { Cinzas 1 } & & \\ \text { Segundo andar } & \text { Brancos 8 } & \text { Cinzas 0 } & & \\ \text { Terceiro andar } & \text { Brancos 8 } & \text { Cinzas 16 } & & \\ \text { Quarto andar } & \text { Brancos 8 } & \text { Cinzas 16 } & \text { Brancos 24 } & \\ \text { Quinto andar } & \text { Brancos 8 } & \text { Cinzas 16 } & \text { Brancos 24 } & \text { Cinzas 32 }\end{array}$

- Descobrir que cada borda a mais acrescenta um número de cubos múltiplo de 8. Deduzir que a diferença para cada andar entre os Brancos e os Cinzas (sempre sem considerar a coluna central) é: Segundo andar $B-C=8$; Terceiro andar: $B-C=-8$; Quarto andar: $B-C=16$; Quinto andar $B-C=-16$, etc.

- Deduzir que, sempre para as bordas acrescentadas, a diferença $B-C$ é igual à soma algébrica das diferenças nos diversos andares. Assim, para dois níveis, diferença 8; três níveis, diferença 0 ; quatro níveis, diferença 16 ; cinco níveis, diferença $0 ; \ldots$; para $\mathrm{n}$ andares, com $\mathrm{n}$ par, a diferença é $8 \mathrm{n}$; para $\mathrm{n}$ andares, com $\mathrm{n}$ ímpar, a diferença é 0 . 
- Calcular os cubos cinzas da coluna central e concluir que no n-ésimo andar, a diferença $C-B$ é $n$ e, portanto, em uma pirâmide de 5 andares, $C-B=5$, enquanto em uma de $11, C-B=11$.

\section{Atribuição de pontos}

4 Resposta exata $(C-B=5, C-B=11)$ com explicações completas.

3 Resposta correta com explicações pouco claras ou resposta correta com explicações claras e somente um erro de cálculo.

2 Resposta correta sem explicações ou dois erros ou imprecisões.

1 Início de raciocínio correto ou resposta com mais de dois erros.

0 Incompreensão do problema.

No enunciado desse problema, vemos o registro em língua natural e figural. Como é preciso considerar a quantidade de cubos brancos e cinzas, a primeira parte da resolução envolve uma conversão ou do registro em língua natural (informações do enunciado), ou do registro figural (contagem dos cubos), para o registro numérico.

Com a obtenção da quantidade de cubos de cada cor, os dados podem ser organizados em uma tabela (registro numérico tabular). É esperado que os alunos representem a situação utilizando esse tipo de registro devido às discussões realizadas em fases anteriores. No entanto, a construção dessa tabela pode variar de acordo com a maneira como se compreende a formação das pirâmides.

Podemos ver, por exemplo, a produção de uma tabela que considere o número de cubos de cada cor em cada andar da pirâmide. Isso porque, no enunciado, cada andar é mostrado primeiro separadamente. Com a tabela, efetua-se a adição das quantidades para uma pirâmide de 5 e 11 andares, em seguida a diferença entre essas quantidades. Apesar de não ser mostrado na figura o quinto antar da pirâmide e os posteriores, nesse caso, há uma correspondência evidente entre o enunciado e os dados em registro numérico. Assim, se a tabela for usada como representação na solução desse problema, essa deve ser mais frequente.

$\mathrm{Na}$ análise a priori vemos uma conversão do registro numérico para o registro algébrico. Para os alunos, essa conversão pode não ser simples, levando-os a preferir o tratamento no registro numérico para concluir a solução.

Por outro lado, outro tipo de tabela é produzido quando se considera a quantidade total de cubos de cada cor em uma pirâmide à medida em que se aumenta um andar. Nesse caso, é possível generalizar a diferença entre a quantidade de cubos 
de cada cor e se chegar à resposta sem a necessidade de efetuar adições com muitas parcelas. O nível de congruência na conversão para a construção dessa tabela é menor, uma vez que o enunciado (em língua natural) descreve a formação de cada andar separadamente e apenas uma pirâmide é mostrada na figura. Pelo mesmo motivo, a possiblidade de solução na análise a priori relacionada, à contagem vertical dos cubos, pode não aparecer entre as soluções dos alunos.

Rali Matemático

PROVA III

(C)ARMT

\section{PARTILHA JUSTA}

Lucas e Catarina herdaram um grande terreno que tem a forma de um trapézio isósceles. Eles querem dividir o terreno em duas partes de mesma área por meio de uma cerca retilínea, partindo de uma estaca que se encontra em um dos lados paralelos do trapézio (na figura, o ponto P).

Desenhem na figura o segmento $P Q$, que divide o trapézio em duas partes de mesma área. Expliquem como determinaram a posição da extremidade $Q$ do segmento e porque as áreas são iguais.

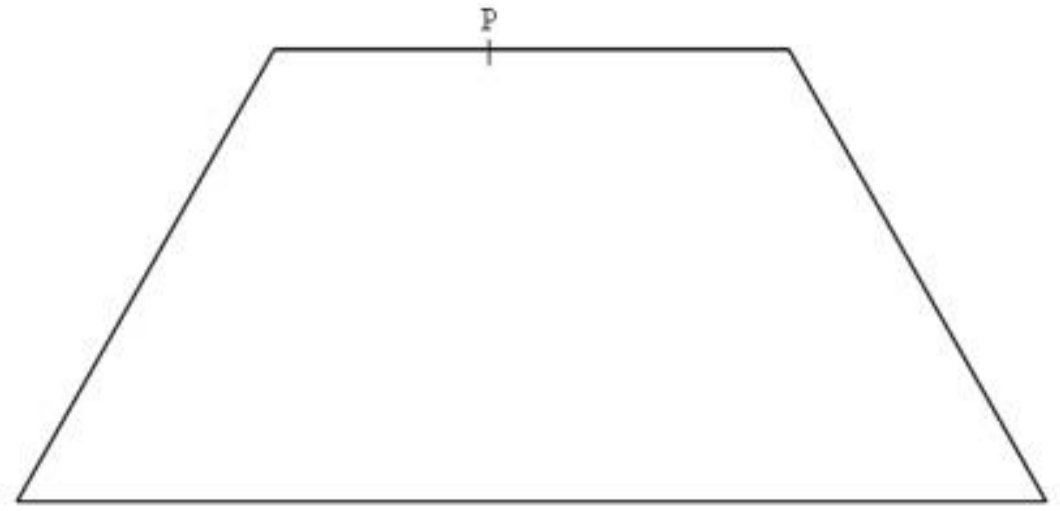

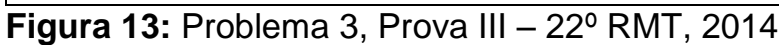

Fonte: http://www.armtint.org/; tradução nossa.

\section{ANÁLISE A PRIORI}

\section{Tarefa matemática}

- Dividir um trapézio isósceles em duas partes de mesma área por um segmento de reta unindo um ponto dado sobre a base menor a um ponto a ser determinado.

\section{Análise da tarefa}

- Compreender que para uma divisão igual, é necessário que as partes de Lucas e Catarina tenham a mesma área.

- Observar que P está sobre a base menor do trapézio, mas não é seu ponto médio.

- Compreender que é necessário, então, traçar um segmento PQ que não é perpendicular à base, pois se fosse, as duas partes obtidas não teriam a mesma área. 
- Sendo $A, B, C, D$ os vértices do trapézio, $M$ o ponto médio de $A D$ e $N$ o ponto médio de $B C$, observar que $M N$ é a mediatriz comum às duas bases do trapézio, dividindo-o em dois trapézios simétricos, ABNM e MNCD.

- Com um compasso ou por uma medida de comprimento precisa, transferir a medida de $P M$ para posicionar o ponto $Q$ sobre $B C$ de tal forma que $N Q=P M$. Os triângulos retângulos $\mathrm{PMO}$ e QNO assim formados têm então a mesma área. Deduzir que as partes $A B Q P$ e $P Q C D$ têm também áreas iguais.

Observar que PM e NQ são paralelos e de mesmo comprimento, deduzir que PNQM é um paralelogramo. $O$ ponto $Q$ sobre $B C$ está, portanto, sobre a paralela a $P N$ que passa por $M$. Ou então, as perpendiculares às duas bases, $A D$ e $B C$, por $A$ e $D$, determinam dois triângulos, $A B E$ e DFC, de mesma área, pois são simétricos em relação à mediatriz $\mathrm{MN}$.

Compreender que resta dividir o retângulo AEFD em duas partes de mesma área pelo segmento $\mathrm{PQ}$.

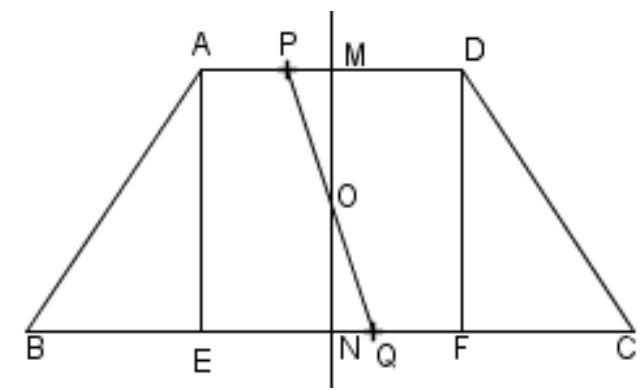

- Transferir a medida AP para posicionar o ponto $Q$ sobre BC de modo que QF = AP. Deduzir que os dois trapézios retângulos AEQP e FDPQ têm a mesma área, pois, sendo da mesma altura, eles têm bases de mesmo comprimento.

Concluir que as partes ABQP e PQCD têm a mesma área pois são compostas de partes de áreas iguais.

Ou, utilizando somente medidas de comprimentos, partir da construção do retângulo AEFD:

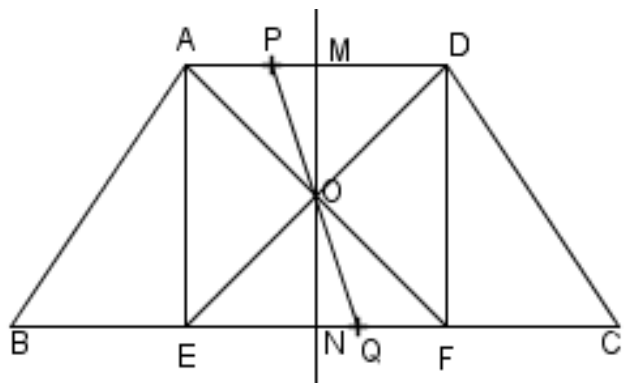

- Medir AD, BC e AP. Deduzir FC = $(B C-A D) / 2$ e colocar o ponto $Q$ sobre $B C$ de modo que $\mathrm{QC}=\mathrm{AP}+\mathrm{FC}$ e verificar, como anteriormente, que as duas partes, $\mathrm{ABPQ}$ 
e PQCD, têm a mesma área. Ou realizar uma construção geométrica utilizando somente a régua, observando que $Q$ de ser o simétrico de $P$ na simetria de centro $O$, situado na interseção das diagonais do retângulo AEFD.

- Traçar a reta $P O$ até encontrar BC, o ponto de interseção assim obtido é $Q$. Deduzir que os dois trapézios AEQP e FDPQ são igualmente simétricos nessa simetria central e têm a mesma área. Concluir que que as parcelas $A B Q P$ e $P Q C D$ têm a mesma área.

\section{Atribuição de pontos}

$4 O$ ponto $Q$ bem colocado, por transferência de comprimentos, ou geometricamente, ou com medidas, com explicação clara de sua construção e do fato de as áreas das partes obtidas serem iguais.

$3 \bigcirc$ ponto $Q$ bem colocado com a apresentação de sua construção, sem justificativa da igualdade das áreas.

20 ponto $Q$ aparentemente bem colocado sem explicações.

1 Início de pesquisa utilizando uma simetria ou com a observação de igualdade das áreas dos triângulos $A B E$ e DFC, mas sem a divisão do retângulo.

0 Incompreensão do problema.

No enunciado, além do registro em língua natural, está presente o registro figural. O processo de solução requer a apreensão perceptiva, para identificação global da figura; apreensão operatória, para subdividir a figura em partes que indicarão a solução; e apreensão discursiva, para que se consiga explicitar as propriedades que levam à conclusão de que as "partes" em que a figura foi decomposta têm mesma área.

Além da divisão da figura em partes de mesma área, é preciso explicar a igualdade das áreas. Essa atividade, portanto, envolverá o registro figural e o registro em língua natural, sendo predominante a apreensão discursiva ao longo do processo de solução.

A princípio, a apreensão perceptiva permite observar que a figura a ser dividida é um trapézio e que o ponto $P$ está sobre sua base menor, porém, não é ponto médio.

A apreensão operatória poderá ser necessária na partição da figura em subfiguras que auxiliarão na solução. Por exemplo: o traçado da mediatriz pelos pontos $M N$ determinará os trapézios $A B N M$ e MNCD; o traçado dos segmentos $A E$ e $D F$, que resultarão no retângulo $A E F D$ e nos triângulos $A B E$ e DEF. É possível recorrer às diagonais do retângulo para uma nova subdivisão. Ou ainda, traçar a perpendicular 
ao lado AD por $\mathrm{P}$, determinando o ponto $\mathrm{S}$ e transferir a medida de AP para encontrar o segmento DP' e, assim, traçar a perpendicular a AD passando por P', determinando o ponto S' e, por fim, o retângulo PSS'P' (Figura 14).

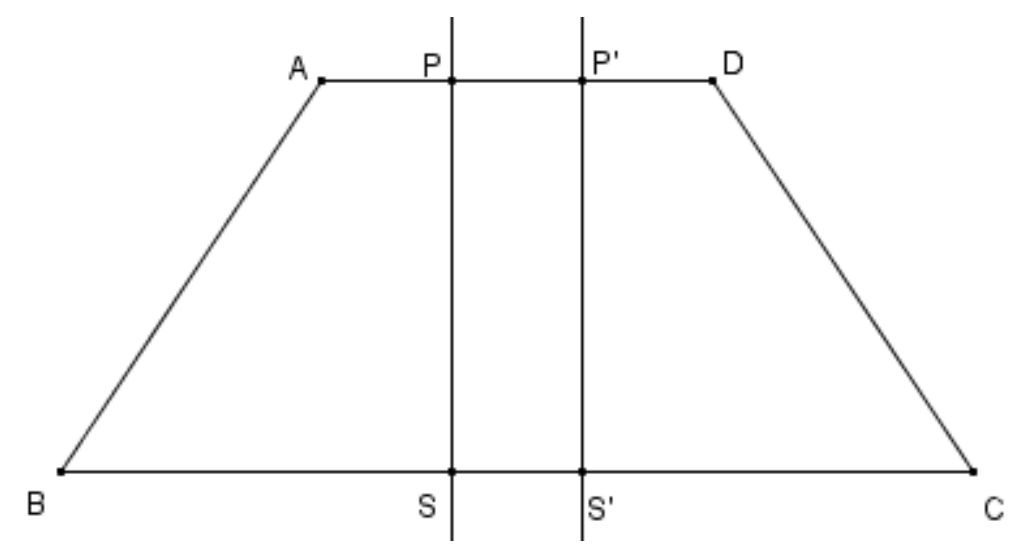

Figura 14: Construção da Solução 1, Problema 1, Prova III - Fase 3 - Etapa 1

Com qualquer uma das divisões, novamente a apreensão perceptiva facilita o reconhecimento das figuras obtidas. Com o reconhecimento, é possível utilizar a propriedades de cada uma delas. Feito isso, o ponto $Q$ será determinado por transferência de medidas, com o uso de régua ou compasso; ou observando que tal ponto é o simétrico de $P$ no segmento $B C$ em relação ao ponto $O$, interseção das diagonais de PSS'P'.

Tendo obtido o ponto $Q$, ainda será necessário verificar a igualdade das áreas obtidas, para isso, é preciso observar, por meio de propriedades de semelhança, que as duas partes das figuras são formadas por figuras de mesma área, como na Figura 15.

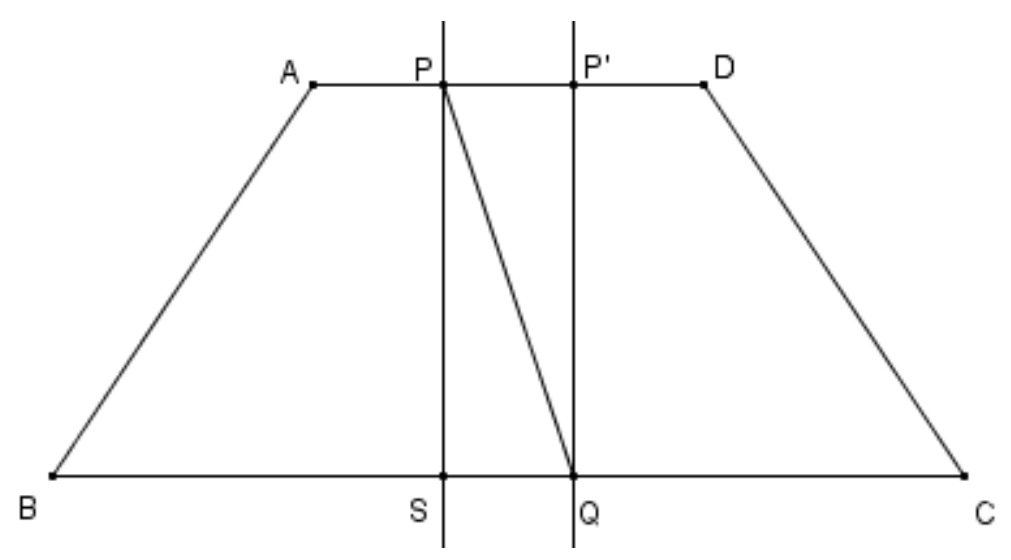

Figura 15: Solução Problema 3, Prova III - Fase 3 - Etapa 1 
O ponto S' que havia sido determinado no exemplo é o ponto $Q$. A diagonal do retângulo PSQP' é o segmento que determina a divisão do trapézio em partes iguais. Temos que os triângulos PSQ e QP'P têm a mesma área. Além disso, considerando os trapézios ABSP e DCQP' formados, como AP e P'D, por construção têm a mesma medida; PS e P'Q têm a mesma medida, pois são alturas de ABCD e BS e QC também têm a mesma medida, os dois trapézios têm a mesma área, logo ACQP e DCQP têm a mesma área.

\subsubsection{Fase 3 - Etapa 2}

Na última etapa do experimento, os problemas da Prova III não são discutidos. Ao final da última prova, os sujeitos respondem a um Questionário Final que nos permite avaliar a maneira como interpretam sua participação no que foi proposto como atividade de Resolução de Problemas. Podemos, ainda, examinar a experiência no que diz respeito à disposição e ao comprometimento em realizar as atividades.

A resposta ao Questionário Final nos fornece, juntamente com os dados obtidos nas fases anteriores, elementos para melhor julgar em que aspectos em que nossos objetivos foram alcançados.

\section{QUESTIONÁRIO}

1. Qual sua opinião sobre a participação no Rali e sobre os problemas propostos em cada etapa (grau de dificuldade, interesse, etc.)

2. Dê uma nota de zero a dez para sua participação no grupo durante a resolução dos problemas do Rali. Justifique.

3. Comente os pontos positivos e negativos dessa experiência em Resolução de Problemas nos moldes do Rali.

Figura 16: Questionário Final - Fase 3 - Etapa 2 


\section{Capítulo 6}

\section{Análise dos Resultados}

\subsection{Organização da análise}

Neste capítulo, será descrita a análise dos dados obtidos a partir da aplicação do experimento detalhado no capítulo anterior. Os resultados de cada fase foram exibidos separadamente, levando em consideração as produções dos alunos.

A pesquisa envolveu a participação de três turmas de $1^{\text {a }}$ série do Ensino Médio, totalizando 97 alunos. Todas as etapas foram realizadas em cada turma e, em todas as turmas, os encontros ocorreram no mesmo dia, no horário das aulas de Matemática. A coleta de dados deu-se num período de aproximadamente seis meses, sendo que a segunda fase ocorreu um mês depois da realização da primeira e a Fase 3 , cerca de três meses após a segunda.

É importante lembrar que, no decorrer do experimento, a professora da turma ou não estava presente, ou não interferia na atividade dos alunos, como preveem as regras do Rali. As instruções eram dadas pela pesquisadora e os alunos só interagiam com ela.

Na Fase 1, as turmas se organizaram em duplas e grupos para a realização da Atividade Inicial e da Prova I, respectivamente. Houve, ainda, o momento em que responderam ao Questionário Inicial individualmente.

Tanto na Fase 2, quanto na Fase 3, os grupos formados na primeira fase foram mantidos para a resolução das provas II e III. Contudo, nesta última fase, os alunos novamente responderam ao Questionário Final individualmente.

Com o intuito de organizar os dados e garantir o anonimato, os alunos, as duplas e os grupos foram denotados por códigos. Nas respostas do Questionário Inicial, os alunos são indicados por 1A, 2A, 3A, e assim por diante. Na Atividade Inicial, as duplas são codificadas de D1, D2, D3 até D47. Nas provas, os grupos são designados G1, G2, ..., G18.

Optamos por fazer os questionários não identificados para evitar inibição dos alunos a respondê-los. Além disso, alguns alunos que responderam o primeiro 
questionário haviam mudado de sala ou não participaram da última etapa, portanto, não vimos a necessidade de manter os mesmos códigos para as respostas dos dois. Sendo assim, no Questionário Final, os códigos dos alunos são 1B, 2B, 3B, e assim, sucessivamente.

Para facilitar a compreensão dos resultados da Atividade Inicial, avaliamos as respostas de acordo com as informações corretas e incorretas dadas pelos alunos.

Nos questionários, buscamos agrupar as respostas semelhantes e basear as análises na frequência dessas respostas para estabelecer as devidas conclusqqões.

Para as avaliações das resoluções dos alunos nas provas, consideramos a atribuição de pontos especificada nas análises a priori com o objetivo de sintetizar as soluções que os alunos foram capazes de produzir corretamente. $\mathrm{Na}$ análise, examinamos as respostas dadas para cada problema separadamente e, para cada prova, organizamos uma tabela que contém a frequência dos pontos obtidos. Além disso, comentamos as principais dificuldade e erros cometidos pelos alunos e, ainda, as principais representações utilizadas.

O principal foco do experimento não eram as discussões realizadas após as provas. Dessa forma, os resultados da Etapa 3 (Fase 1) e Etapa 2 (Fase 2) se restringem a destacar apenas aspectos essenciais para a realização das atividades.

\subsection{Resultados Fase 1}

\subsubsection{Resultados Etapa 1 - Fase 1}

Iniciamos a primeira etapa da Fase $1 \mathrm{com}$ uma atividade em que os alunos deveriam responder a duas questões envolvendo triângulos retângulos. Conforme previsto, eles se organizaram em duplas. No total, 47 duplas, distribuídas nas três turmas, realizaram a atividade.

Optamos por classificar as soluções dos alunos em cada questão de acordo com cinco categorias: resposta correta, início correto sem conclusão, início correto com erros na conclusão, início incorreto e sem resposta. Dessa forma podemos apontar aspectos comuns nas resoluções.

Para a primeira questão, obtivemos os resultados mostrados na Tabela 4. 


\begin{tabular}{|l|c|}
\hline \multicolumn{2}{|c|}{ QUESTÃO 1 - Atividade Inicial } \\
\hline Respostas corretas & 42 \\
\hline Início correto sem conclusão & 3 \\
\hline $\begin{array}{l}\text { Início correto com erros na } \\
\text { conclusão }\end{array}$ & 1 \\
\hline Início incorreto & 1 \\
\hline Sem resposta & 0 \\
\hline
\end{tabular}

Tabela 4: Resultado Questão 1, Atividade Inicial - Fase 1 - Etapa 1

Como mostra a tabela, a questão 1 foi respondida corretamente por 42 duplas. Apenas uma delas observou que, pelos valores dos catetos dados no enunciado, tratava-se de uma tripla pitagórica e não realizou cálculos, somente a conversão para o registro figural. As demais realizaram os mesmos registros: figural, com os valores das medidas dos catetos e, em seguida, o registro algébrico, utilizando a relação do Teorema de Pitágoras, como ilustra a figura abaixo.

1.Qual a medida da hipotenusa de um triângulo retângulo cujos catetos medem 3 e $4 \mathrm{~cm}$ ?
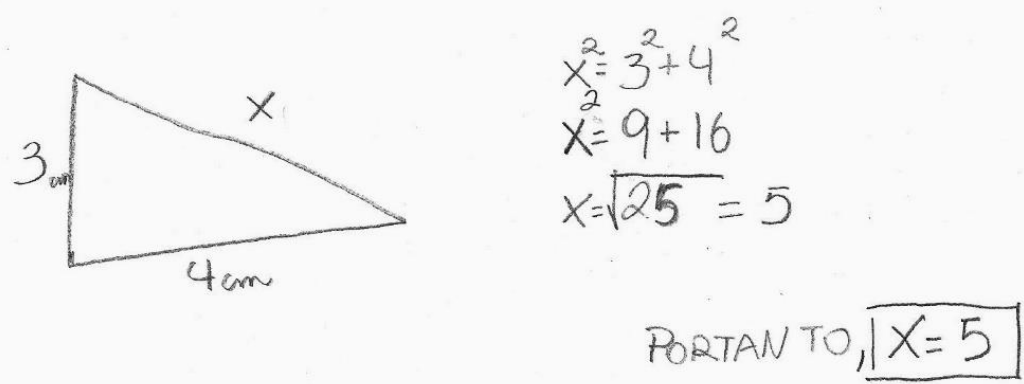

Figura 17: Solução da Dupla D4 - Questão 1, Atividade inicial

Das duplas que não chegaram à resposta final, duas fizeram a figura, escreveram a relação do Teorema de Pitágoras, mas não concluíram. Uma traçou a figura, escreveu a fórmula, substituiu os valores, porém cometeu erros de tratamento no registro simbólico algébrico. Outra apenas traçou a figura e a última não realizou corretamente a conversão do registro em língua natural para o registro figural, pois fez a representação de dois retângulos: um com comprimento igual a $3 \mathrm{~cm}$ e outro com 
comprimento igual a $4 \mathrm{~cm}$, sem qualquer menção às larguras. É provável que tenham considerado apenas o termo "retângulo" no enunciado.

O índice de acerto da questão (aproximadamente 89\%) era esperado, confirmando nossas considerações da análise a priori.

Já na segunda questão, o número de informações corretas nas soluções diminuiu consideravelmente, conforme mostra a Tabela 5, o que também era esperado.

\begin{tabular}{|l|c|}
\hline \multicolumn{2}{|c|}{ QUESTÃO 2 - Atividade Inicial } \\
\hline Respostas corretas & 0 \\
\hline Início correto sem conclusão & 0 \\
\hline $\begin{array}{l}\text { Início correto com erros na } \\
\text { conclusão }\end{array}$ & 3 \\
\hline Início incorreto & 31 \\
\hline Sem resposta & 13 \\
\hline
\end{tabular}

Tabela 5: Resultado Questão 2, Atividade Inicial - Fase 1 - Etapa 1

Dentre as duplas que iniciaram a solução corretamente, todas consideraram que o quadrado MNOP tem a mesma área de IJKL, como na Figura 18. O erro cometido é na identificação do lado de medida $3 \mathrm{~cm}$, que consideram ser a medida do lado do quadrado MNOP.

A solução da dupla D13 é exibida abaixo.
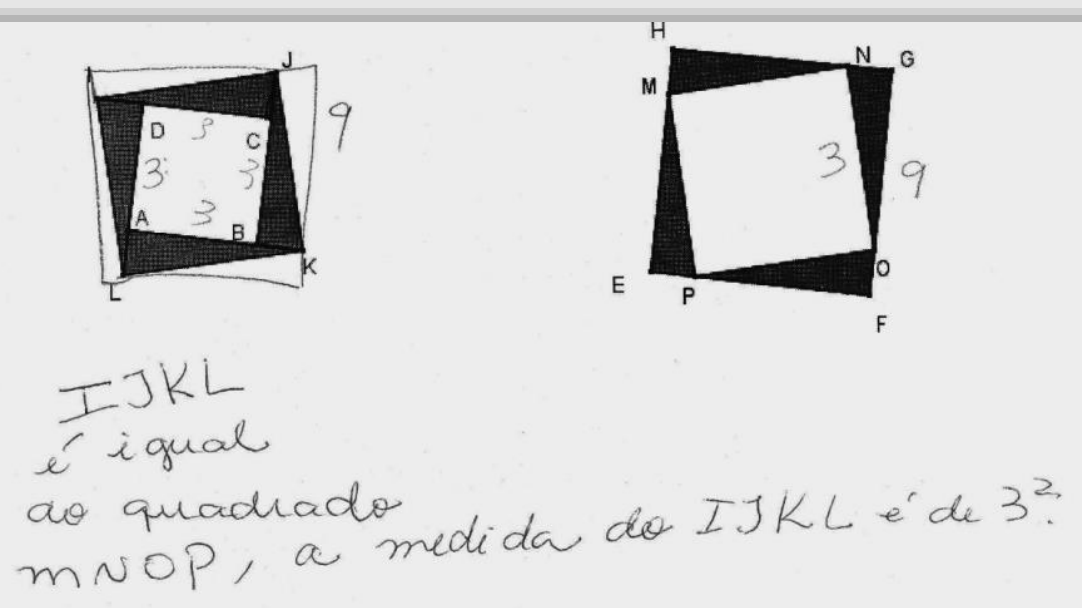

Figura 18: Solução da Dupla D13 - Questão 2, Atividade Inicial 
Vemos que, com a apreensão perceptiva, os alunos foram capazes de identificar os triângulos retângulos que formavam a figura. Utilizando uma reconfiguração, posicionaram corretamente os triângulos para formar o quadrado EFGH a partir do quadrado IJKL. A dupla mencionou a igualdade entre os quadrados IJKL e MNOP, mas não fizeram a correspondência do lado de medida $3 \mathrm{~cm}$ corretamente, inviabilizando a solução obtida.

$\mathrm{Na}$ categoria dos alunos que iniciaram a solução incorretamente, os erros mais comuns podem ser subdivididos em dois tipos. O primeiro leva em consideração as medidas exibidas no enunciado para, de alguma maneira, utilizar o Teorema de Pitágoras, sem observar a que essas medidas se referem. É o caso das respostas ilustradas abaixo (Figuras 19 e 20).


Figura 19: Solução da Dupla D10 - Questão 2, Atividade Inicial 

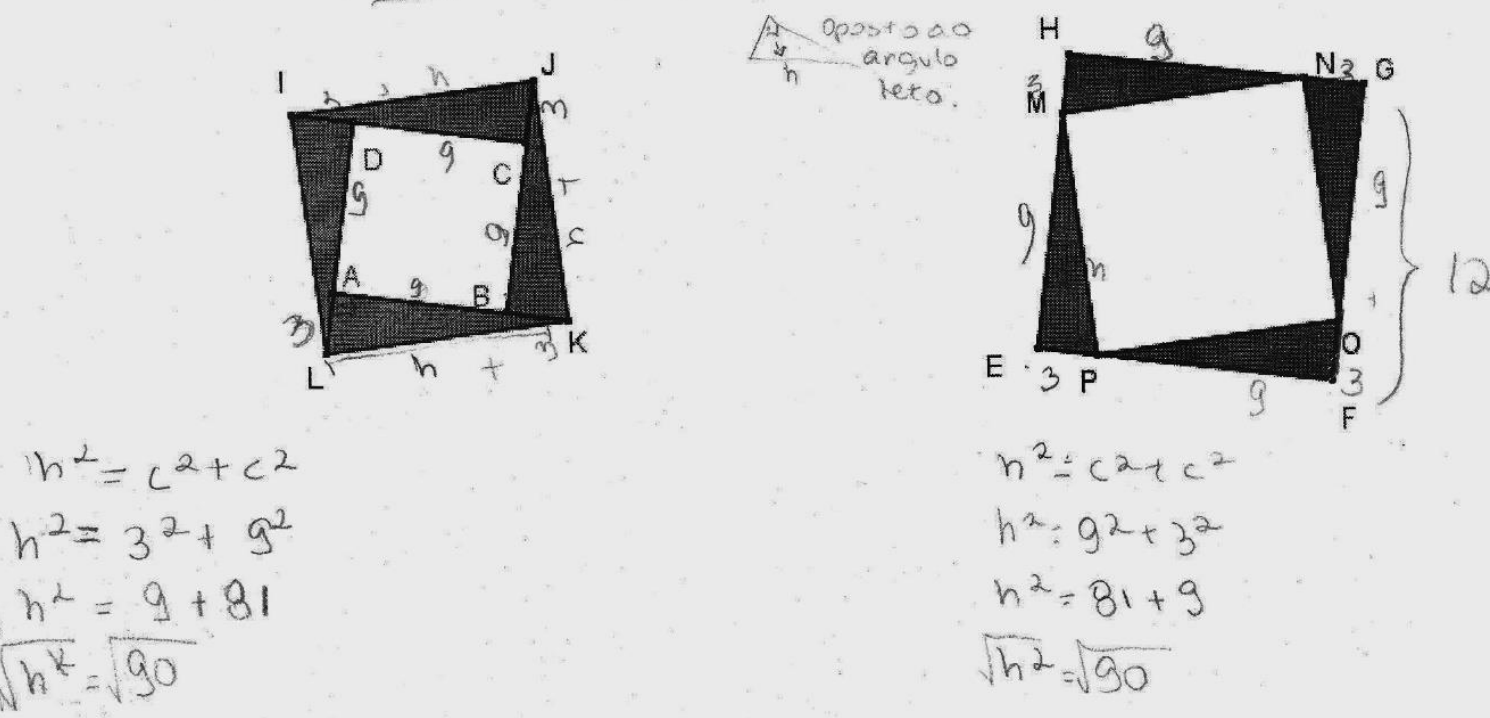

Figura 20: Solução da Dupla D1 - Questão 2, Atividade Inicial

Esse erro pode ter sido cometido porque os alunos esperavam encontrar a resposta diretamente, da forma como fizeram na primeira questão. Tal fato pode ser explicado pelo que já mencionamos anteriormente sobre o que colocam Echeverría e Pozo (1998): os alunos podem não estar habituados a esse tipo de atividade e, portanto, tentam reduzi-las a exercícios rotineiros.

O segundo tipo de erro para a questão revela uma falha na compreensão dos conceitos de área e perímetro. Os alunos parecem notar uma relação entre as áreas dos quadrados $A B C D$ e EFGH, mas efetuam cálculos de perímetros das figuras. Um exemplo de resposta é mostrado na Figura 21. Esse tipo de erro pode estar relacionado à dificuldade em dissociar área e perímetro, apontada em pesquisas da área como, por exemplo, em Bellemain e Lima (2002). 

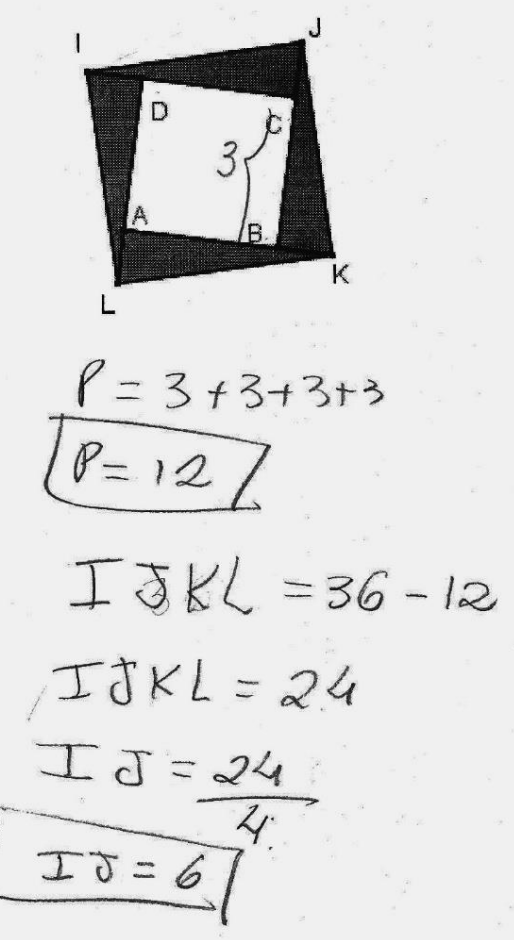
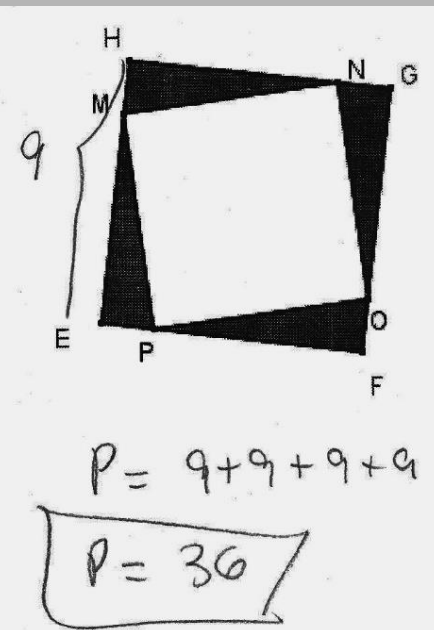

Figura 21: Solução da Dupla D5 - Questão 2, Atividade Inicial

Os resultados dessa Atividade Inicial nos revelam que os alunos estão habituados a resolver questões em que se prevê a aplicação direta de uma relação. No entanto, não mostram habilidade e familiaridade com situações que exijam mais recursos cognitivos e elaboração de estratégias mais complexas para sua solução.

Segundo a abordagem teórica de Robert ${ }^{17}$ (1997 apud Santos; Curi, 2009), a primeira questão está relacionada com o nível técnico de conhecimento, já que a resolução da tarefa está associada à utilização de uma ferramenta. Nesse caso, a fórmula do Teorema de Pitágoras. Por outro lado, a segunda questão corresponde ao nível de conhecimento mobilizável, uma vez que os alunos deveriam mobilizar conhecimentos prévios para adaptar a uma noção explícita - no caso, o mesmo teorema - e resolver a tarefa. A autora alerta que, quanto mais implícita a noção em jogo, maior a dificuldade do aluno em identificá-la e utilizá-la corretamente na solução.

17 ROBERT, Aline. Quelques outils d'analyse épistémologique et didactique de connaissances mathématiques à enseigner au lycée et à l'université. Actes de la IX Ecole d'Etè de Didactique des Mathématiques. Houlgate. França, 1997. 
Após a execução dessa atividade, em cada turma, os alunos foram questionados a respeito de diferenças entre as duas questões propostas. Nas três classes, os comentários foram na mesma direção:

- "O primeiro é mais fácil que o segundo".

- "Precisamos pensar mais para resolver o segundo. No primeiro tínhamos certeza de que a resposta estava certa".

- "Demoramos mais para fazer o segundo".

Assim, pudemos observar que o objetivo inicial da atividade foi alcançado: a primeira questão foi respondida como um exercício rotineiro e a segunda se caracterizou como um problema de fato, no sentido descrito no Capítulo 3. Além disso, tivemos a primeira impressão sobre a relação dos alunos com a Resolução de Problemas e em Matemática.

Após essa atividade, foi pedido que os alunos respondessem o questionário (cf. p. 68) para que pudéssemos obter mais informações a respeito de suas opiniões e experiências com Resolução de Problemas.

Ao todo, 94 questionários foram respondidos. Apenas a terceira pergunta não tinha alternativa; para as demais, além da escolha "SIM" ou "NÃO", pedia-se uma justificativa para a resposta. Apresentamos abaixo um gráfico com as respostas objetivas das questões 1, 2, 4, 5 e 6, para que se tenha uma visão geral. Em seguida, comentamos as respostas de cada questão, bem como da questão 3.

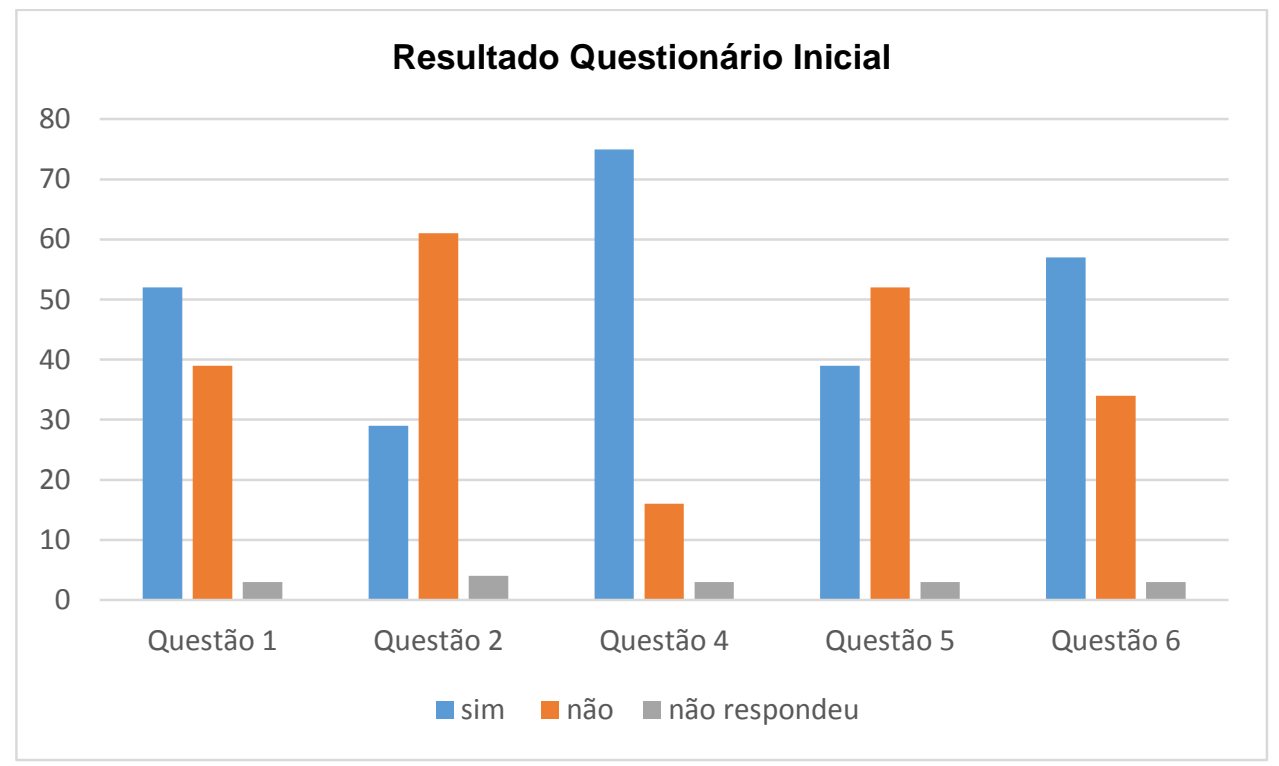

Gráfico 1: Resultado Questionário Inicial 
De maneira geral, podemos notar que, apesar de a maioria dos alunos gostar de Matemática (Questão 1), é maior a quantidade daqueles que não se consideram bons alunos (Questão 2). Em relação aos problemas, eles reconhecem propostas de resolução e resolvem problemas apenas nas aulas de Matemática (Questão 4). Podemos, ainda, observar uma semelhança entre as respostas para a primeira (Você gosta de Matemática?) e a última questão (Você gosta de resolver problemas ou desafios de Matemática), mostrando a ligação entre o gosto pela Matemática e o gosto por resolver problemas.

Nas justificativas das respostas de cada questão, pudemos distinguir pontos em comum que facilitaram a obtenção de mais informações a respeito das relações dos sujeitos com a Matemática e a Resolução de Problemas. Os comentários sobre as respostas serão expostos junto à reprodução das repostas dadas por alguns alunos, consideradas representativas de cada questão.

Entre os alunos que gostam de Matemática, percebemos semelhanças entre as justificativas que podem ser representadas por algumas categorias de respostas: o gosto pela Matemática ligado à sua precisão; utilidade prática no cotidiano ou em futuras profissões; desenvolvimento do raciocínio e os que classificam atividades em Matemática como experiências positivas. Abaixo, vemos algumas respostas que ilustram essas categorias.

\begin{tabular}{|c|}
\hline Você gosta de Matemática? Por quê? \\
\hline 52 Respostas: Sim \\
\hline $\begin{array}{l}\text { "Porque gosto da forma exata, ou é certo ou errado, não tem várias possibilidades como português." } \\
(1 \mathrm{~A})\end{array}$ \\
\hline "Porque envolve o que eu quero ser no meu futuro (arquitetura)." (55A) \\
\hline "Porque além de ter a ver com o meu futuro, querendo ou não faz parte da nossa vida." (79A) \\
\hline "Porque ajuda no raciocínio e desenvolver habilidades." (86A) \\
\hline "Porque me ajuda a ter mais foco, eu treino mais o meu raciocínio." (63A) \\
\hline "É sempre bom estar fazendo exercícios, é divertido e distrai." (81A) \\
\hline "Porque eu gosto de fazer contas e me sinto bem quando acho a solução de um problt \\
\hline
\end{tabular}

Quadro 17: Respostas "sim" à Questão 1 do Questionário Inicial 
A maioria dos alunos que responderam que não gostam de Matemática, justificaram relatando dificuldades em compreender a disciplina. Outros alunos mencionaram atividades relacionadas com Matemática como pontos negativos e, ainda, indicam adjetivos que descrevem a Matemática para eles (cf. Quadro 18).

\begin{tabular}{|l|}
\hline \multicolumn{1}{|c|}{ Você gosta de Matemática? Por quê? } \\
\hline \multicolumn{1}{|c|}{ 39 Respostas: Não } \\
\hline "Porque tenho dificuldade em compreender a matéria na maioria das vezes. "(73A) \\
"Porque não consigo entender. "(32A) \\
"Porque eu não gosto pelo fato de envolver contas e cálculos, que para mim eu tenho grande \\
dificuldade." (47A) \\
"Porque eu não gosto de números e cálculos. " (81A) \\
"Porque matemática é difícil e me confunde, aí eu não consigo aprender". (82A) \\
"Porque é chato, tem muito detalhe. " (5A) \\
"Porque é confuso e complicado." (48A) \\
"Porque é chato e cansativo. "(29A)
\end{tabular}

Quadro 18: Respostas "não" à Questão 1 do Questionário Inicial

Para a segunda pergunta, três categorias definem similaridades nas justificativas das respostas daqueles que se consideram bons alunos em Matemática: esforço e disposição para realizar todas as tarefas solicitadas; facilidade na compreensão do conteúdo e interesse. Abaixo, listamos alguns exemplos de respostas.

\begin{tabular}{|l|}
\hline \multicolumn{1}{|c|}{ Você se considera um bom aluno em Matemática? Por quê? } \\
\hline 29 Respostas: Sim \\
\hline "Porque sempre me esforço para fazer e conseguir entender o exercício. ” (39A) \\
"Me empenho em aprender e concluir um cálculo. " (37A) \\
"Sou interessada e faço tudo o que o professor pede. ” (65A) \\
"Porque faço todos os exercícios que a professora pede, tenho boas notas e me esforço para \\
entender a matéria". (66A) \\
"Porque tenho facilidade na matéria". (74A) \\
"Pois me interesso bastante pelo assunto. "(88A) \\
Quadro 19: Respostas "sim" à Questão 2 do Questionário Inicial
\end{tabular}

Quadro 19: Respostas “sim” à Questão 2 do Questionário Inicial 
Já os alunos que assinalaram "Não" para essa questão, podemos destacar os seguintes grupos de justificativas: falta de esforço; falta de concentração; notas ruins e, a grande maioria das respostas, aqueles que declaram não saber ou ter dificuldade em Matemática.

\begin{tabular}{|l|}
\hline \multicolumn{1}{|c|}{ Você se considera um bom aluno em Matemática? Por quê? } \\
\hline "Não consigo me esforçar o bastante. "(46A) \\
"Porque eu acho que poderia me esforçar mais. "(36A) \\
"Me desconcentro muito fácil. " (38A) \\
"Mesmo estudando não consigo tirar notas altas. "(9A) \\
"Porque não consigo atingir as minhas metas de notas. " (6A) \\
"Porque eu tenho dificuldade em entender a lógica da matemática e decorar fórmulas. " (2A) \\
"Pois não entendo, me sinto confusa e perdida nas aulas. " (68A) \\
"Eu tento de tudo, mas tenho muitas dificuldades. "(18A) \\
"Porque não sei praticamente nada ao que se refere matemática. " (94A)
\end{tabular}

Quadro 20: Respostas "não" à Questão 2 do Questionário Inicial

Como já mencionamos, a Questão 3 não tinha alternativas, então, para análise das respostas, observamos as que ocorreram com mais frequência. Sendo assim, reproduzimos as respostas que melhor descrevem a opinião da maioria dos alunos a respeito de um problema. Percebemos que a maioria dos alunos considera que problema é um exercício ou uma situação que envolve objetos e procedimentos matemáticos, como números, operações e resolução de equação. Alguns mencionam que sempre existe uma fórmula para resolver um problema e todos os problemas têm solução a ser descoberta. 


\section{Para você, o que é um problema de Matemática?}

"É um exercício para treinar o que já aprendemos. ” (62A)

“Um exercício que junta várias habilidades. ” (16A)

"Qualquer problema que envolva cálculos. " (20A)

"É uma situação que envolve matemática. " (84A)

"Uma questão que tem solução e tem que ser encontrada da melhor forma. " (25A)

Quadro 21: Respostas à Questão 3 do Questionário Inicial

Poucos alunos identificam diferença entre um problema e um exercício. Esses poucos indicam que um problema nem sempre é algo simples de ser resolvido e reconhecem que, a partir do momento em que se chega à solução, não se tem mais um problema. Além disso, alguns mencionam o desenvolvimento do raciocínio. No quadro abaixo, vemos exemplos desse tipo de resposta.

\section{Para você, o que é um problema de Matemática?}

"Problema é quando tem uma série de dados e no final tem uma questão e você tem que fazer algo para achar o resultado. " $(66 \mathrm{~A})$

"Problema é algo bem complicado de fazer, mas sempre terá uma solução. " (15A)

"Um problema de matemática é um conjunto de informações que precisam de organização para chegar a um resultado. " $(71 \mathrm{~A})$

"Aquele em que eu quebro a cabeça para resolver. " (26A)

“Um problema de matemática é algo para melhorar o raciocínio. ” (56A)

"Algo que se possa resolver para que simplifique e não seja mais um problema. " (76A)

Quadro 22: Respostas à Questão 3 do Questionário Inicial

A partir das respostas, vemos que os sujeitos não diferenciam exercícios de problemas da maneira como discutimos no Capítulo 3. Isso revela que há grandes chances de que uma atividade proposta a eles como exercício, seja vista como problema. Essa pode ser a razão pela qual observamos maior quantidade de respostas "Sim" para a Questão 4 (75 em 94): Você resolve problemas ou desafios nas aulas de Matemática?

A Questão 5 também estava relacionada com a Resolução de Problemas, mas, nesse caso, à resolução em ocasiões diferentes das aulas de Matemática. A maior 
parte dos alunos que afirmou resolver problemas ou desafios fora das aulas de Matemática, mencionou apenas tarefas propostas pela professora, que eles concluem em casa, ou estudo de algo que não tenham compreendido em sala. Além disso, esses alunos ainda mencionaram as atividades que desenvolvem na plataforma Khan Academy ${ }^{18}$.

Por essas respostas, vemos, mais uma vez, que o entendimento que os alunos têm de problemas não os diferencia dos exercícios escolares. Cabe destacar que, ao buscarmos as atividades da plataforma, vemos que a maioria das atividades realizadas pelos alunos na aula de informática, contêm apenas exercícios de cálculos.

Alguns alunos informaram que encontram desafios em jogos de vídeo-game ou xadrez, por exemplo. Outros, que percebem a atividade de resolução de um problema ao realizar operações que envolvem contagem de dinheiro no dia-a-dia.

\begin{tabular}{|l|}
\hline Você resolve problemas ou desafios fora das aulas de Matemática? Quais? \\
39 Respostas: Sim \\
52 Respostas: Não (não comentaram) \\
\hline "Na sala me sinto confusa, fora me sinto mais calma e menos pressionada. " (53A) \\
"Aqueles que não entendo em sala, faço como lição de casa. " (37A) \\
"Na plataforma Khan e em jogos. " (75A) \\
"O Khan Academy e as lições de casa pedidas. " (73A) \\
"No Khan Academy e os da vida, como compras no mercado. "(25A)
\end{tabular}

Quadro 23: Respostas à Questão 5 do Questionário Inicial

No que concerne à Questão 6, dentre os alunos que informaram gostar de resolver problemas, há aqueles que restringem o gosto por problemas que sabem resolver. Em geral, esses mencionam o interesse por problemas que envolvem conteúdos que foram tratados em aula e que compreendem. Por isso, podemos interpretar que os problemas que resolvem estão relacionados a uma abordagem de ensino para a resolução de problemas ou, então, que são problemas de aplicação de um conteúdo exposto previamente.

\footnotetext{
${ }^{18}$ A Khan Academy é uma ONG educacional criada e sustentada por Salman Khan. Trata-se de um site que disponibiliza exercícios, vídeos de instrução e um painel de aprendizado personalizado. É um recurso que a escola utiliza durante as aulas da disciplina de Laboratório de Informática.

Disponível em: www.khanacademy.org. Último acesso em: 03 fev. 2015.
} 
Alguns alunos reconhecem, na resolução de problemas, um meio de melhorar o raciocínio e habilidades matemáticas e, ainda, uma maneira de aprender. Outros, descrevem sensações positivas ao resolver um problema. Abaixo, exibimos algumas das respostas.

\begin{tabular}{|l|}
\hline \multicolumn{1}{|c|}{ Você gosta de resolver problemas ou desafios de Matemática? Por quê? } \\
\hline \multicolumn{1}{|c|}{57 Respostas: Sim } \\
\hline "Quando eu entendo a matéria é até divertido resolver os problemas." (2A) \\
"Tenho dificuldade, mas quando entendo, eu gosto." (67A) \\
"Quando eu entendo o que é pra fazer e como fazer." (42A) \\
"Depende dos problemas. Os que mais gosto são de Bháskara, Pitágoras e simplificação de raízes." \\
"65A) \\
"Sim, é sempre mo ajuda a aprimorar os conhecimentos matemáticos. " (74A) \\
"Sim, sinto satisfação quando acho a solução. " (88A) \\
“[... sinto felicidade ao resolver um desafio. " (63A)
\end{tabular}

Quadro 24: Respostas "sim" à Questão 6 do Questionário Inicial

Dos que responderam que não gostam de resolver problemas, a maioria não justificou a resposta. Entre os alunos que justificaram, podemos distinguir três padrões de respostas: os que não gostam de resolver problemas porque não gostam de Matemática; os que não gostam pois, por algum motivo, não conseguem resolver; e os que relatam não gostar devido às dificuldades em Matemática. Alguns exemplos dessas respostas são mostrados no Quadro 25.

\begin{tabular}{|l|}
\hline \multicolumn{1}{|c|}{ Você gosta de resolver problemas ou desafios de Matemática? Por quê? } \\
\hline 34 Respostas: Não \\
\hline "Porque eu não gosto da matéria, eu acho muito complicada. ” (8A) \\
"Porque eu não gosto de matemática. " (5A) \\
"Porque não sei fazer a maioria. " (7A) \\
"Eu não consigo resolver rápido e fico sem paciência. ” (21A) \\
"Porque eu não me dou bem com números e acabo tendo dificuldade. " (39A) \\
Quadro 25: Respostas "não" à Questão 6 do Questionário Inicial
\end{tabular}

Quadro 25: Respostas “não" à Questão 6 do Questionário Inicial 
As análises dos dados obtidos na Etapa 1 mostram que a relação dos sujeitos com a Matemática e com a Resolução de Problemas reflete as experiências que eles têm, ou tiveram, com a disciplina.

Notamos que o entendimento que eles têm sobre a disciplina se baseia na reprodução de técnicas. Isso se revela nos resultados da Atividade Inicial, em que os alunos foram capazes de determinar a solução da Questão 1 com facilidade, mas não mostraram habilidade em mobilizar os conhecimentos necessários para resolução da Questão 2. A tentativa mais frequente, nessa questão, foi procurar uma maneira de aplicar a mesma técnica utilizada na questão anterior, sem avaliar seu significado.

Em relação ao questionário, destacamos a maioria dos alunos relata gostar tanto de Matemática, quanto de resolver problemas - na maneira como entendem a definição de problema. No entanto, muitos reconhecem suas limitações e se apoiam nelas para justificar que não gostam da disciplina, de resolver problemas ou que não se consideram bons alunos.

De maneira geral, concluímos que os alunos não estão familiarizados com a atividade de Resolução de Problemas da maneira como pretendíamos realizar, nem com o tipo de problemas que proporíamos. Além disso, muitos tentariam reduzir as situações propostas à aplicação de uma técnica.

Assim, levando em consideração que se tem um problema quando não possuímos um método ou regra para resolver uma situação, os problemas de todas as provas podem se caracterizaram como reais problemas por aqueles alunos.

\subsubsection{Resultados Fase 1 - Etapa 2}

$\mathrm{Na}$ Etapa 2 da primeira fase, conforme já descrito, foi proposto que os alunos resolvessem três problemas do Rali Matemático em grupos. A avaliação das soluções dadas foi feita para cada problema, considerando particularidades e respostas frequentes, com base nas análises a priori e nos tipos de registro observados.

Quando a Prova I foi aplicada, os alunos foram orientados a formar grupos de, no mínimo, cinco pessoas, de modo que, em cada turma tivéssemos, seis grupos. Dessa forma, um total de dezoito grupos resolveu as provas. 
A formação dos grupos foi mantida na realização de todas as provas, exceto pela ausência de um ou outro integrante, o que não interferiu nos resultados obtidos.

Para cada prova, iniciamos a análise com a tabela que mostra o desempenho geral dos alunos, tomando uma classificação de acordo com o número de pontos obtidos em cada problema. Devemos lembrar que a pontuação corresponde com aquela estabelecida nas análises a priori.

A Tabela 6 apresenta a pontuação dos grupos na Prova I. Por essa tabela, podemos notar, primeiramente, que nenhum grupo acertou uma questão completamente, atingindo a pontuação máxima de 4 pontos, com resultado e explicações corretas. O Problema 3 foi, aparentemente, o mais difícil para eles, já que a maioria não obteve pontuação. Nas outras questões, a maior parte dos grupos obteve pelo menos um ponto, mostrando, ao menos, compreensão das situações propostas.

\begin{tabular}{|c|c|c|c|c|c|c|}
\hline \multicolumn{7}{|c|}{ PROVA I } \\
\hline $\begin{array}{c}\text { Pontos } \\
\text { atribuídos }\end{array}$ & 0 & 1 & 2 & 3 & 4 & Média \\
\hline Problema 1 & 4 & 9 & 5 & 0 & 0 & 1.05 \\
\hline Problema 2 & 6 & 10 & 2 & 0 & 0 & 0.77 \\
\hline Problema 3 & 15 & 3 & 0 & 0 & 0 & 0.17 \\
\hline
\end{tabular}

Tabela 6: Resultado Prova I - Fase 1 - Etapa 2

No Problema 1, entre os grupos que obtiveram zero como pontuação, apenas um não exibiu uma solução. Em dois casos, notamos incompreensão do problema, uma vez que não consideraram que cada trator deve ser utilizado pelo menos uma vez. É o caso da solução do grupo G12 exibida na Figura 22, abaixo.

Vemos que a conversão do registro em língua natural para o registro numérico não foi feita corretamente: eles efetuam divisões que representam a distribuição em números iguais de tanques grandes e médio, separadamente, de acordo com a capacidade de cada tipo de trator. Além disso, não há coerência na escolha do número de viagens baseada nas divisões. 


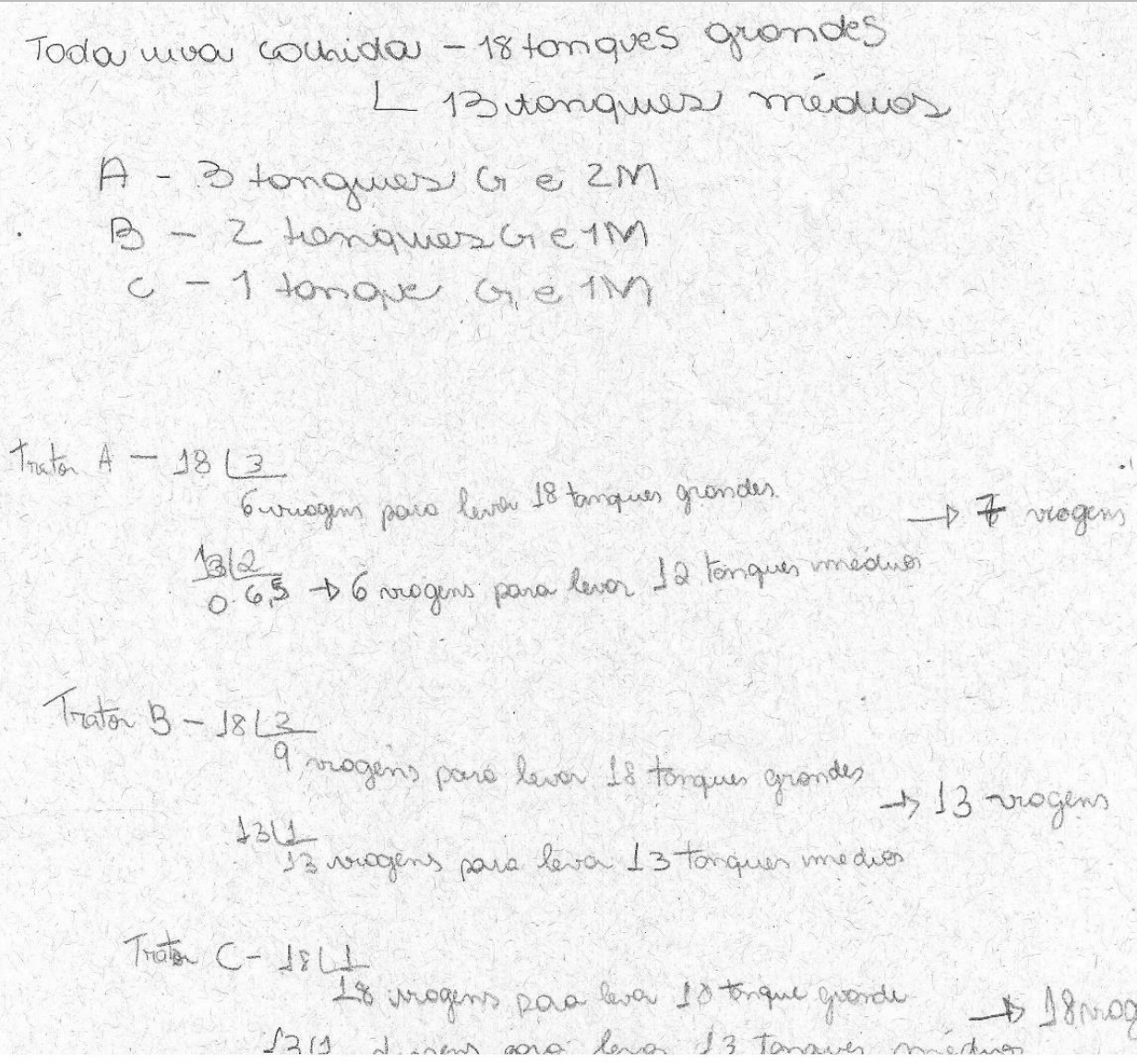

Figura 22: Solução do Grupo G12 - Problema 1, Prova I

O grupo G11, também com pontuação zero, mostrou diversas multiplicações, sem explicações, nem organização. Na Figura 23, abaixo, podemos observar anotações de uma resposta final que revelam incompreensão do enunciado, pois consideram válidos os resultados das multiplicações efetuadas e exibem como resposta, por exemplo, 78 médios e 112 grandes. 


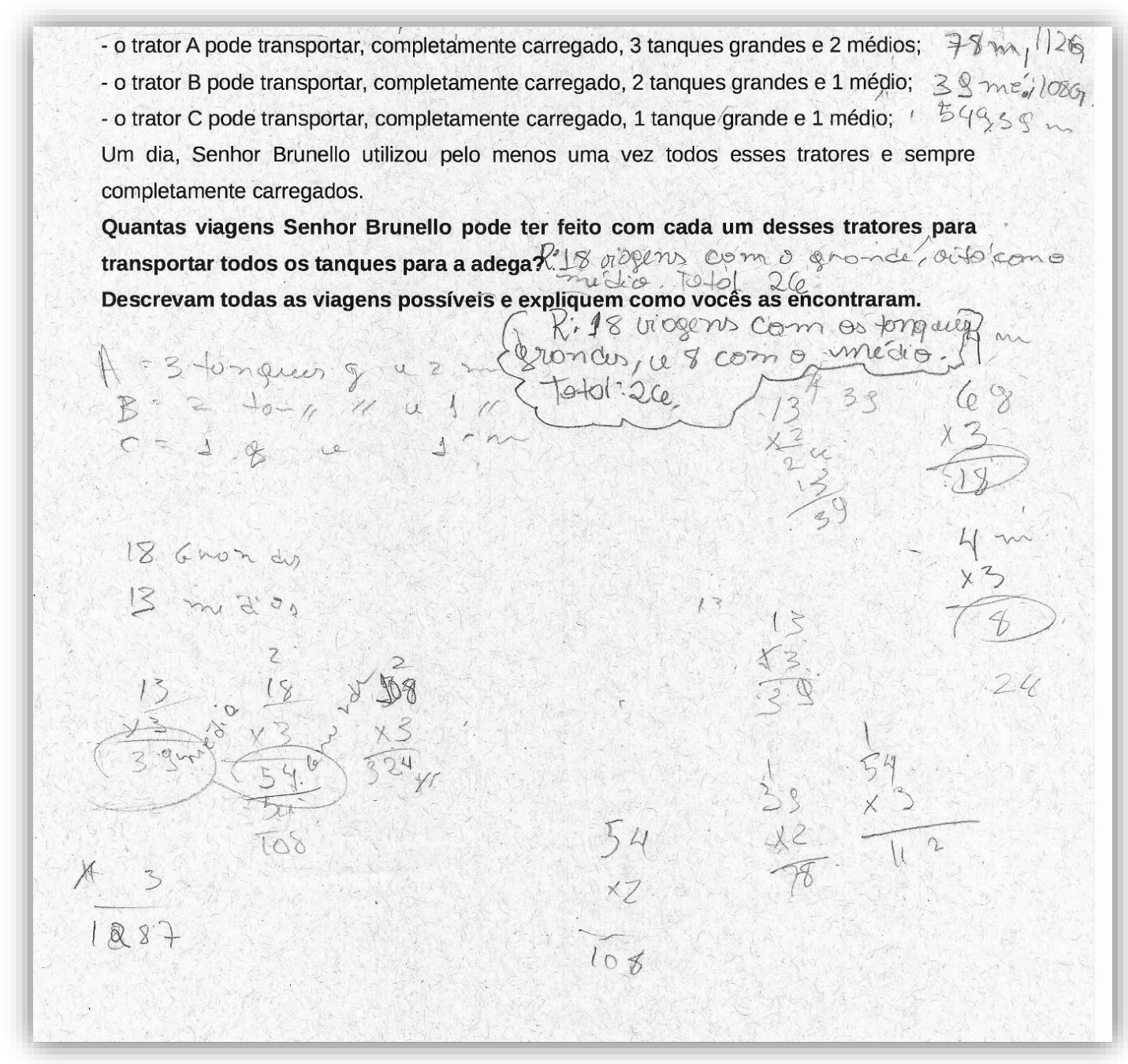

Figura 23: Solução do Grupo G11 - Problema 1, Prova I

Como já indicado, nesse problema, a maioria dos grupos obteve um ponto. Entre as soluções, todas apresentam, mesmo que de forma desorganizada, uma compreensão da situação.

Apenas um dos grupos apresentou uma conversão do registro da língua natural para o registro numérico tabular. Na Figura 24, temos a solução apresentada pelo grupo G2, em que podemos notar o preenchimento da tabela em correspondência com os dados do enunciado. Nesse caso, a utilização desse tipo de registro não facilitou na obtenção de uma resposta correta para o problema. Interpretar as informações dessa tabela não seria uma tarefa fácil. Além disso, ao dar a resposta, o grupo não considerou o fato de que os tratores deveriam estar completamente carregados em todas as viagens. 




Figura 24: Solução do Grupo G2 - Problema 1, Prova I

Os outros grupos procederam por meio de tentativas, mais ou menos organizadas, realizando uma conversão do registro da língua natural para o registro numérico, mas apenas um deles chegou a uma das possibilidades de resposta. Em geral, não são exibidas maiores explicações sobre as tentativas, mas, na Figura 25, vemos que o grupo G3 considerou, primeiramente, uma viagem para cada trator e verificou quantas viagens precisariam acrescentar para cada um a fim de que todos os tanques fossem transportados. Conforme esperado, o grupo em questão não prosseguiu na busca por outras possíveis respostas, contentando-se com uma delas.

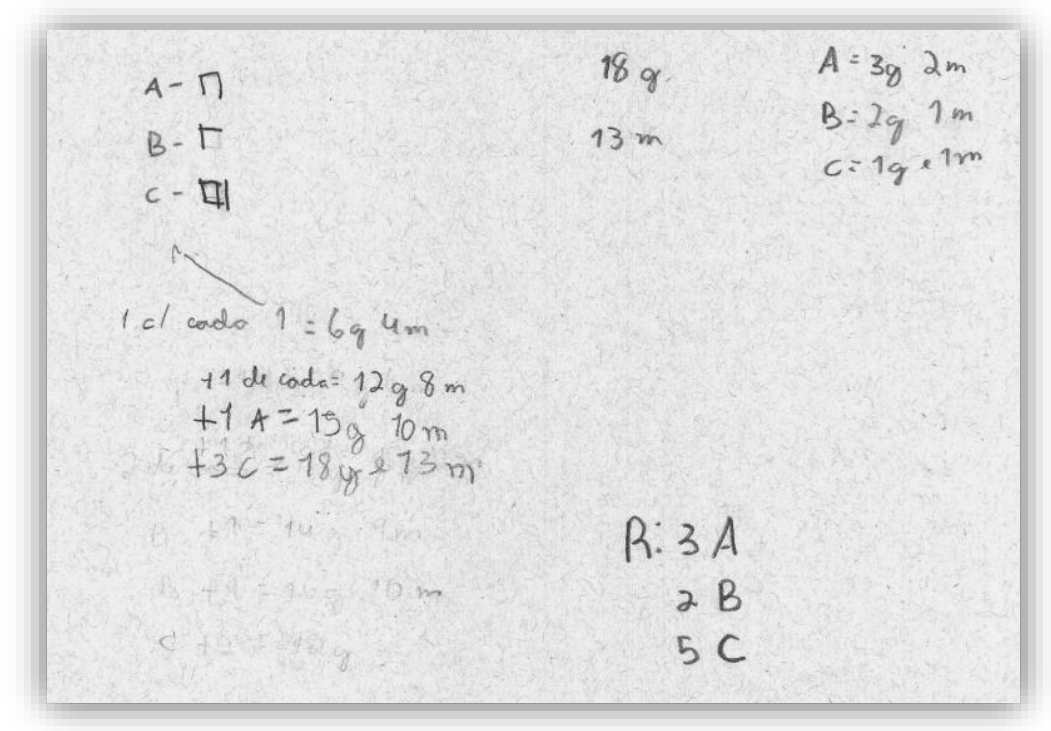

Figura 25: Solução do Grupo G3 - Problema 1, Prova I 
Os grupos que não obtiveram ao menos uma das respostas possíveis cometeram erros de tratamentos no registro numérico ou não tiveram sucesso nas tentativas empregadas. É o caso da solução do grupo G1, na Figura 27. O procedimento utilizado foi o de subtrair a quantidade de tanques transportados à medida em que consideravam uma viagem de determinado trator. No entanto, em umas das subtrações efetuaram $12-3=11$, o que fez com que precisassem de mais tratores do que previa a resposta.

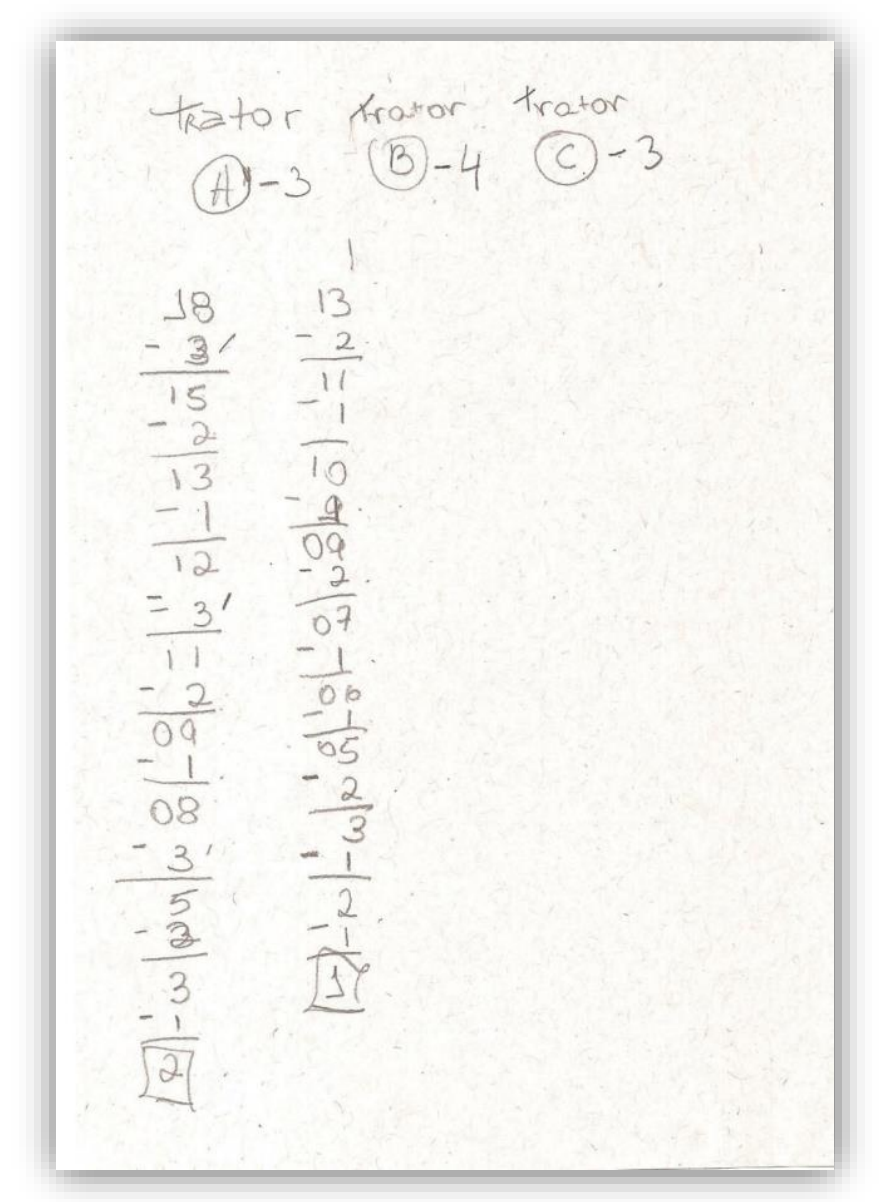

Figura 26: Solução do Grupo G1 - Problema 1, Prova I

Por fim, temos os grupos que obtiveram dois pontos em suas resoluções. Todos esses grupos obtiveram mais de uma das soluções possíveis utilizando, em alguns casos, sucessivas subtrações como recurso, da maneira como foi feito no exemplo anterior, porém, sem erros. Um dos grupos explicou, por meio de registro em língua natural que fizeram uma tabela. Encontraram duas das soluções, no entanto, não há o registro da tabela. 
O grupo G18 obteve duas possibilidades realizando, aparentemente, a adição da quantidade de tanques transportados a cada viagem considerada. A cada tentativa, acrescentaram uma viagem para um dos tratores organizando-as em um registro que se assemelha a uma tabela (cf. a solução na Figura 27).

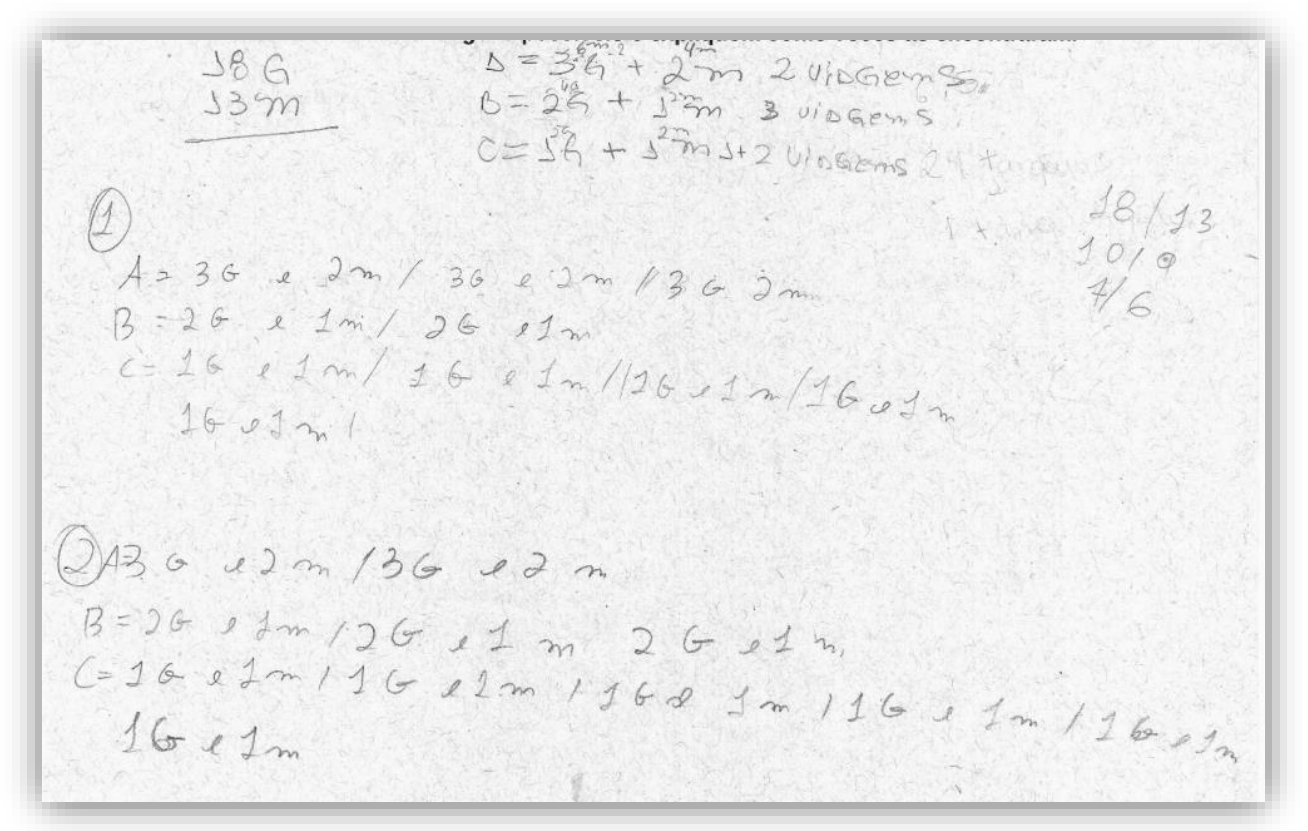

Figura 27: Solução do Grupo G18 - Problema 1, Prova I

No problema 2, dos grupos que não obtiveram pontuação, três não apresentaram solução ou tentativa de resolução (cf. Tabela 7). Outros três mostraram falha na compreensão do enunciado pois fizeram a contagem do número de quadradinhos da figura utilizados para o traçado da espiral, sem levar em consideração que o desenho deveria continuar.

\begin{tabular}{|c|c|c|c|c|c|c|}
\hline \multicolumn{7}{|c|}{ PROVA I } \\
\hline $\begin{array}{c}\text { Pontos } \\
\text { atribuídos }\end{array}$ & 0 & 1 & 2 & 3 & 4 & Média \\
\hline Problema 2 & 6 & 10 & 2 & 0 & 0 & 0.77 \\
\hline
\end{tabular}

Tabela 7: Resultado Problema 2 - Fase 1 - Etapa 2

Como no primeiro problema, também foi maior a ocorrência de notas 1 , o que revela somente compreensão da situação. O grupo G17 esboçou o início de uma solução correta, mas cometeu diversos erros na resolução. Como podemos ver na Figura 28, os alunos começaram a escrever uma sequência de números que mostrava 
o comprimento de cada segmento, horizontal e vertical, alternadamente. Com isso, notamos que não tiveram dificuldade na conversão do registro figural para o registro numérico, o que era esperado. Após escreverem quatro números, indicaram uma continuidade e o último comprimento como sendo 15. Tal equívoco pode estar relacionado ao fato de vincularem a palavra "quinquagésimo", do enunciado, com o número 15 e não com 50, como seria o correto.

Em seguida, um novo engano: estabeleceram uma conversão do registro numérico (sequência) para o registro simbólico algébrico ao considerarem a sequência descrita como uma progressão aritmética. Encontraram a razão 5, observando apenas os dois primeiros números da sequência e, portanto, a fórmula do termo geral escrita, não descreve a sequência obtida.

$$
\begin{aligned}
& \left(\begin{array}{ccc}
b_{1} 1,7,2 & 15 \\
a_{1}, a_{2}, a_{3}, a_{4} & a_{n}
\end{array}\right) \\
& x=a_{2}-a_{1} \\
& a_{n}=a_{1}+(n-1) \cdot r \\
& r=1-6 \\
& 15=6+(n-1) \cdot 5 \\
& 15=6+14 n-5 \\
& x=5 \\
& 15=15 \mathrm{~cm} \\
& a n=15
\end{aligned}
$$

Figura 28: Solução do Grupo G17 - Problema 2, Prova I

Outros cinco grupos que obtiveram nota 1, também identificaram a formação de uma progressão aritmética, mas tiveram mais sucesso na conversão do registro numérico para o registro algébrico, pois consideraram as sequências de comprimentos de segmentos verticais e horizontais separadamente. No entanto, quatro deles apenas utilizaram o procedimento para chegar ao comprimento do último segmento vertical, a partir da fórmula do termo geral da progressão aritmética, como na solução do grupo G16 (Figura 29). 
Dois grupos com a mesma pontuação exibiram uma adição de comprimentos correta, que demonstrava a compreensão da situação, mas cometeram erros ou não concluíram os cálculos.

Outros dois grupos indicaram uma organização dos dados do problema que, apesar de não ser um registro bem estruturado, percebe-se um alinhamento com a tabela proposta na análise a priori, pois observa-se a relação do comprimento de segmentos horizontais e verticais, separadamente, com a sua posição na figura.

Um desses grupos, o G2, parece ter utilizado a fórmula do termo geral de uma progressão aritmética para verificar o comprimento do último segmento horizontal a ser considerado, como vemos na Figura 31.

Nos casos descritos, o registro numérico pode ter facilitado o reconhecimento da P.A. Nenhum dos grupos concluiu a soluções pois não efetuou a soma de todos os comprimentos.

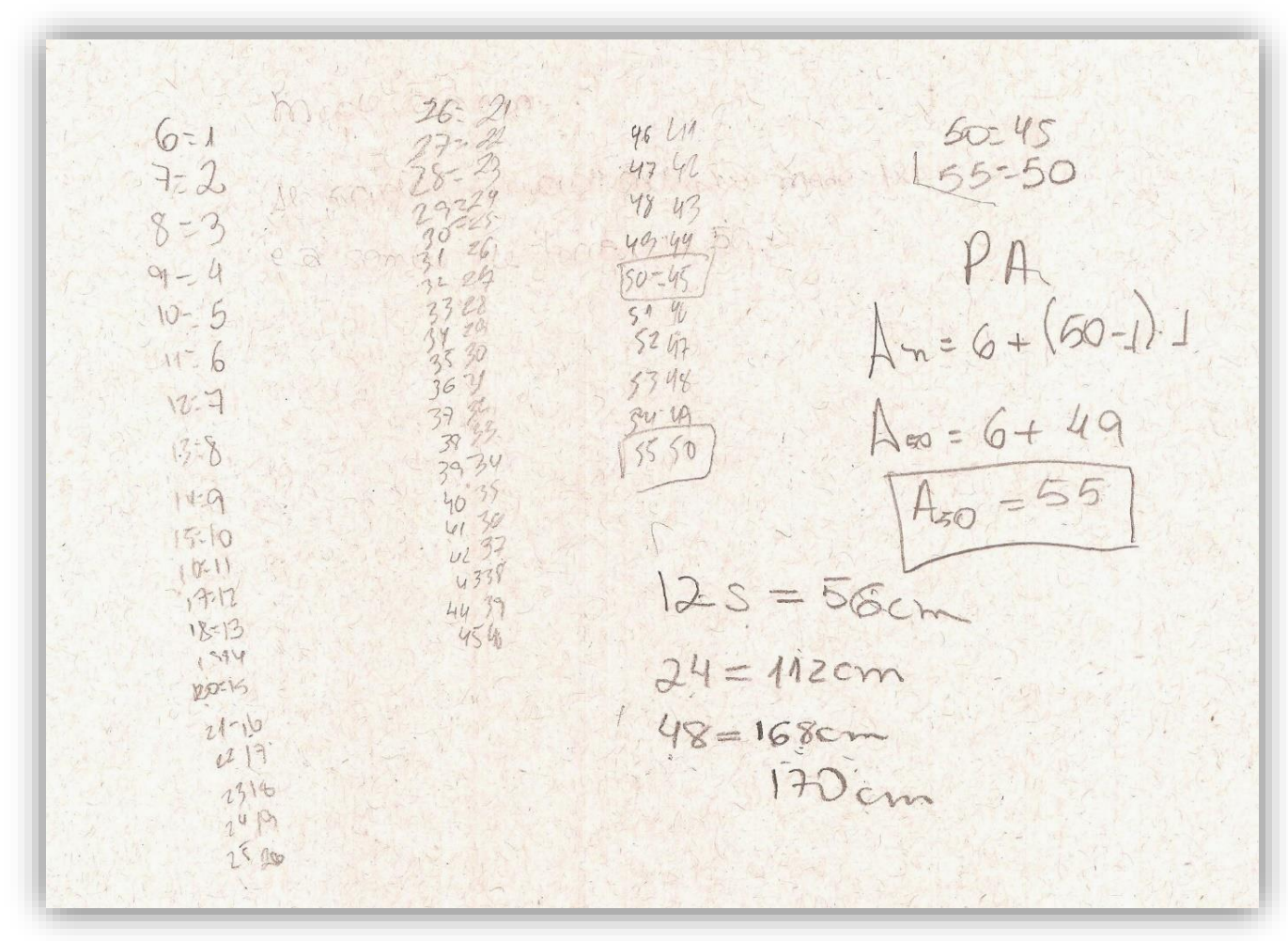

Figura 31: Solução do Grupo G2 - Problema 2, Prova I

Dos grupos que obtiveram 2 pontos, um deles (G12) também organizou um registro parecido com o da Figura 31, entretanto efetuaram a soma de todos os comprimentos de segmentos que indicaria a resposta final. Os únicos impedimentos 
para a que chegassem à solução correta foram, além de não exibirem explicações, erros de cálculo.

O grupo G3 utilizou expressões do termo geral e soma dos termos de uma progressão aritmética para as duas sequências: de comprimentos de segmentos, verticais e horizontais, separadamente. Na Figura 32, podemos ver, no entanto, um erro no tratamento no registro numérico soma dos termos da P.A., o que impossibilitou que chegassem à solução correta.



Figura 32: Solução do Grupo G3 - Problema 2, Prova I

De todos os problemas, considerando as três provas, o terceiro da Prova I foi o menos pontuado. Apenas três grupos obtiveram um ponto, o restante, zero, como vemos na Tabela 8.

\begin{tabular}{|c|c|c|c|c|c|c|}
\hline \multicolumn{7}{|c|}{ PROVA I } \\
\hline $\begin{array}{c}\text { Pontos } \\
\text { atribuídos }\end{array}$ & 0 & 1 & 2 & 3 & 4 & Média \\
\hline Problema 3 & 15 & 3 & 0 & 0 & 0 & 0.17 \\
\hline
\end{tabular}

Tabela 8: Resultado Problema 3 - Fase 1 - Etapa 2 
Dentre os grupos que não obtiveram pontos (15 em 18), nove não produziram qualquer tentativa de solução. Dos outros, dois utilizaram papel quadriculado para refazer o desenho exibido no enunciado, porém, não prosseguiram com a solução.

Dos que não utilizaram papel quadriculado, dois tentaram proceder por reconfiguração, mas a conclusão não foi satisfatória, pois, embora tenham identificado corretamente as novas figuras obtidas, tentaram descobrir a medida de suas áreas mediante uma conversão para o registro simbólico (fórmulas de área) e não encontraram valores para substituir nas incógnitas.

O grupo G14, mostrando incompreensão da situação, exibiu um cálculo do volume de um cubo de aresta $10 \mathrm{~cm}$. Os grupos restantes, após a utilização de tratamento do registro numérico, a partir dos dados do enunciado, exprimiram uma explicação em língua natural.

Um deles (G16) efetuou o cálculo da área total do quadrado e justificando que ele é composto por partes de duas cores diferentes, dividiram o valor obtido por dois.

O grupo G8 calculou incorretamente a área total do quadrado e, utilizando o mesmo procedimento (incorreto), calculou a área das partes de cada cor (Figura 33). Mais uma vez, o erro pode ter sido influenciado por não conseguirem as medidas necessárias para substituir em uma fórmula.

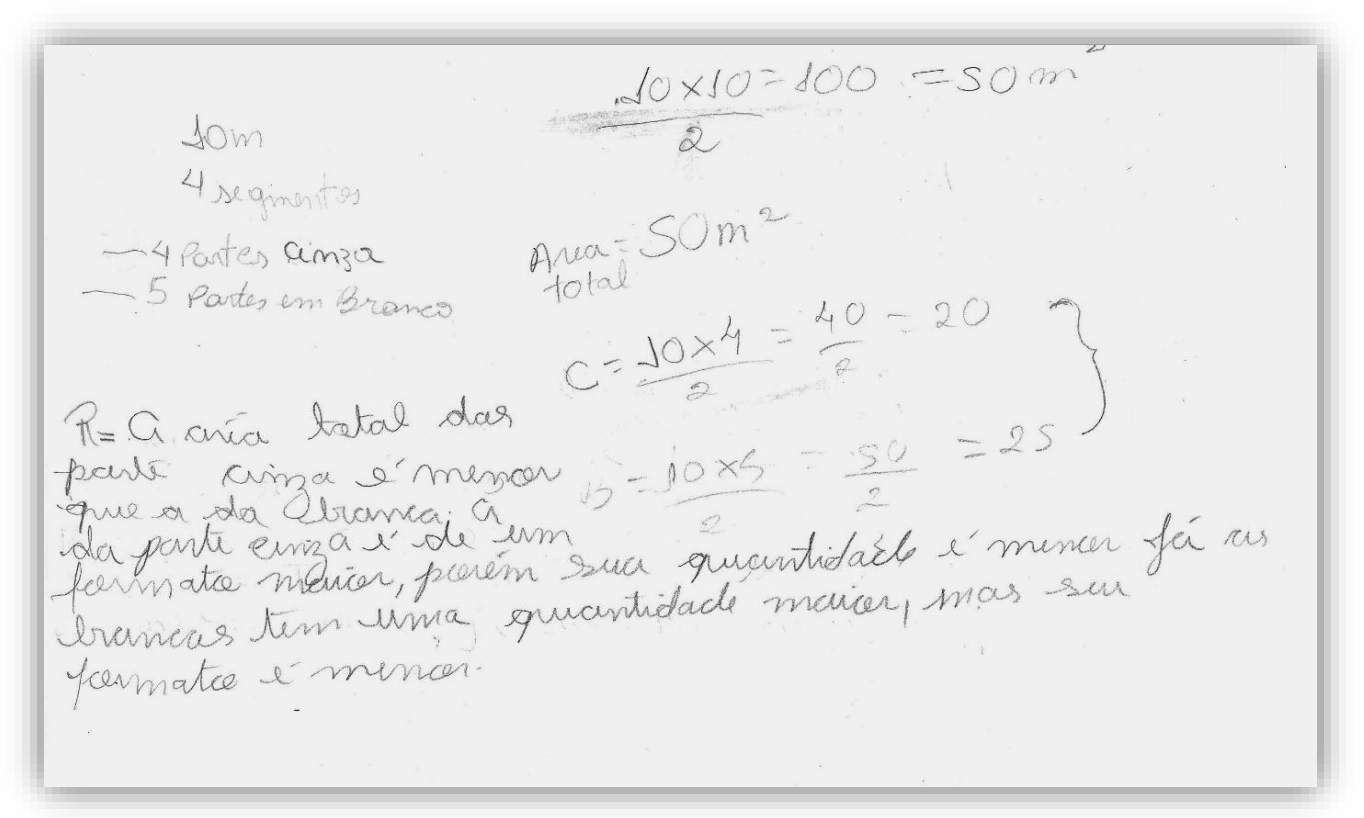

Figura 33: Solução do Grupo G8 - Problema 3, Prova I 
Dos grupos que obtiveram pontuação nesse problema ( 3 em 18), o G4, além do desenho no papel quadriculado, apresentou uma tentativa por reconfiguração, unindo dois trapézios, mas não concluíram. Além disso, efetuaram o cálculo da área do quadrado e, ainda, dois cálculos envolvendo o Teorema de Pitágoras (Figura 34). Esses alunos identificaram os triângulos retângulos na figura e, conhecendo a medida da hipotenusa, tentaram encontrar a medida dos catetos.

Por essa solução, vemos que, mesmo sem chegar a uma conclusão válida, o grupo mostrou apreensão perceptiva ao identificar triângulos retângulos e um retângulo a partir da união de dois trapézios. O que atrapalhou a resolução foi a tentativa do cálculo da área desse triângulo pela conversão para o registro algébrico, já que desconheciam as medidas necessária para tal cálculo.



José observa seu esboço e se pergunta de qual formato serão as diferentes partes e se a área de todas as partes brancas será a mesma das partes cinzas juntas.

Calculem a área total das partes brancas e a das partes cinzas, dando detalhes de como pensaram e dos cálculos realizados.
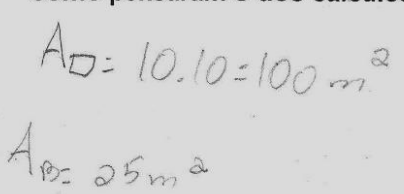

$A=b \times h$

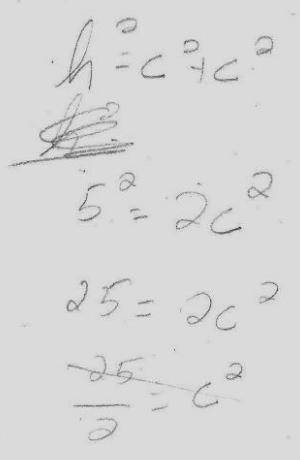

Figura 34: Solução do Grupo G4 - Problema 3, Prova I 
O grupo G9, não utilizou o papel quadriculado; apenas modificou a figura unindo dois triângulos pequenos no próprio desenho do enunciado, mas cometeram os mesmos erros vistos na Figura 34, na tentativa de calcular as áreas.

O terceiro grupo que obteve um ponto na resolução do problema foi o G18. Os alunos refizeram o desenho no papel quadriculado apenas para confirmar as partes que compunham a figura. No processo de solução, exibiram um registro figural para representar uma reconfiguração, à qual deram exatamente esse nome ao explicar o procedimento utilizado, em língua natural.

No registro figural produzido pelos alunos (Figura 35), vemos que os triângulos menores foram posicionados dois a dois para a formação de retângulos; o mesmo foi feito com os trapézios. Eles obtiveram alguns valores, mas as explicações não estão claras.

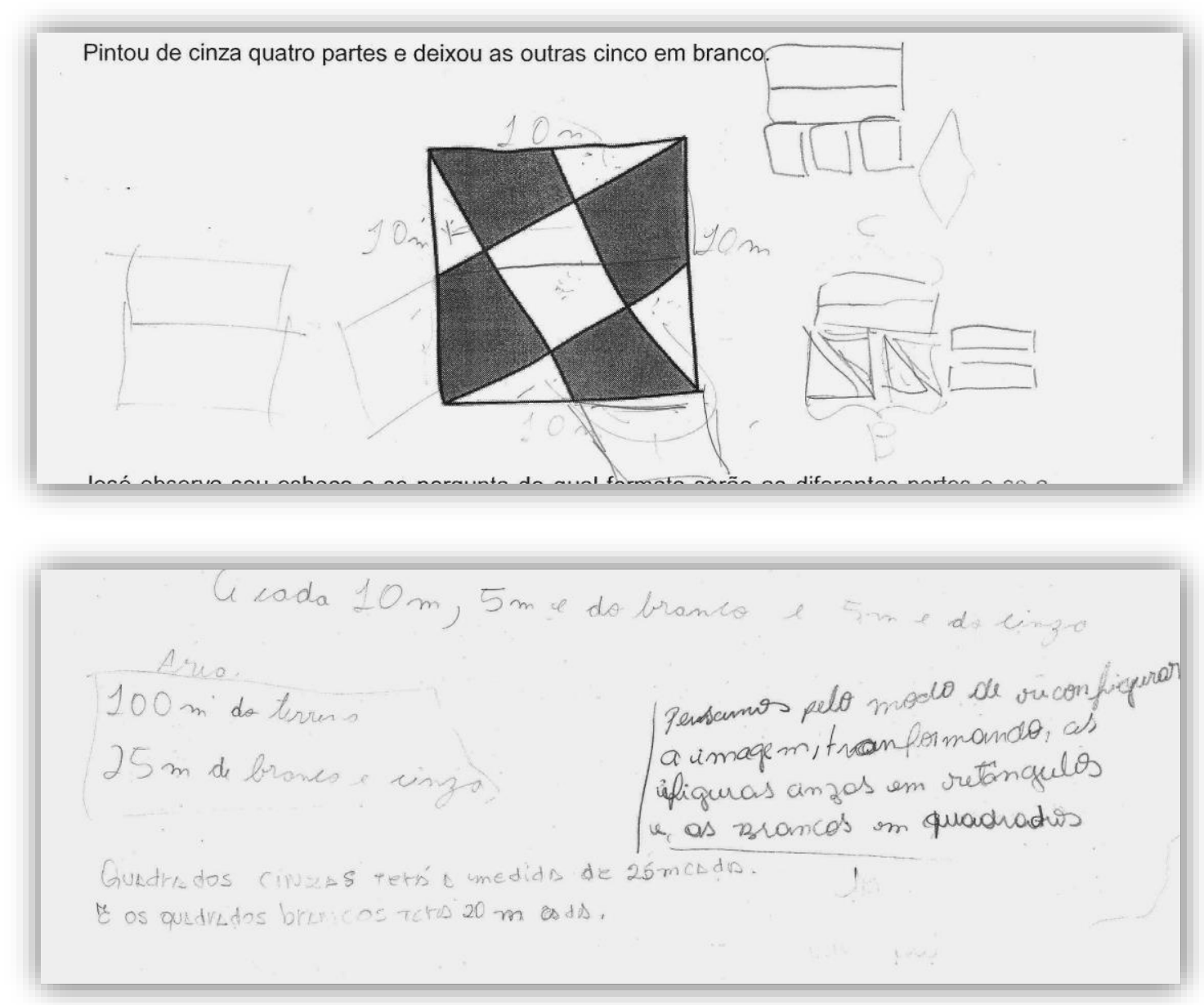

Figura 35: Solução do Grupo G18 - Problema 3, Prova I 
Pelas respostas dos alunos aos problemas da Prova I, notamos que, apesar de alguns terem produzido diferentes representações para as situações propostas, dificilmente eles organizam adequadamente as ideias na busca por soluções. Têm preferência pelo registro numérico, mas não são capazes de mobilizar diferentes tipos de representações para uma situação. Isso significa que eles parecem não ter, por exemplo, habilidade em produzir, ou optar, por certo tipo de representação, uma vez que a primeira tentativa não lhes é útil.

Percebemos, ainda, que nenhum dos grupos apresentou a explicação ou justificativa do raciocínio utilizado, mesmo sendo solicitado em todos os problemas. Isso pode ter sido gerado pela falta de organização e pode indicar que os alunos não utilizam os procedimentos conscientemente.

Em geral, como antecipado na Etapa 1, os alunos tentam encontrar, nos problemas, informações que favoreçam a utilização de uma fórmula conhecida, muitas vezes sem ter real compreensão sobre seu significado.

Os problemas propostos envolveram os alunos na busca pela solução. Alguns alunos que, no princípio, pareceram desanimados com a atividade, ao ver os colegas se dedicando às resoluções, mudaram de atitude e também passaram a ajudar o grupo.

\subsubsection{Resultados Fase 1 - Etapa 3}

A Etapa 3 foi destinada à discussão dos problemas da Prova I em cada uma das turmas participantes. Em cada turma, soluções semelhantes, corretas, ou não, foram encontradas. Por isso, as discussões foram conduzidas da mesma maneira. Nas três, os problemas propostos foram considerados de grande dificuldade e muitos relataram não ter conseguido concluir as soluções.

Todos os problemas foram lidos novamente e todas as dificuldades, quanto à compreensão do que estava sendo solicitado, foram esclarecidas. As discussões foram conduzidas de modo que o objetivo principal fossem as justificativas e resoluções possíveis, não somente a resposta final.

No Problema 1, os alunos disseram não ter entendido que era necessário que todos os tratores estivessem completamente carregados em todas as viagens 
consideradas. Muitos assinalaram que o único procedimento utilizado foi a resolução por meio de tentativas. Em duas turmas, alunos se prontificaram a explicar seu método de resolução. Um deles descreveu:

- "Eu fui subtraindo os tranques que eram transportados até zerar e cheguei numa resposta".

Esse aluno não soube responder quando questionado se a solução que obteve era a única possível, mas um integrante de outro grupo disse que, com o mesmo processo, tinha chegado a outras respostas. Os alunos concordaram que as duas respostas eram corretas e se colocaram a pensar quantas soluções haveriam. Eles não mostraram outra maneira de pesquisar as respostas se não por tentativas, utilizando o mesmo procedimento citado acima.

Com essa observação, a pesquisadora passou a questionar os alunos visando à construção da Tabela 2 (p. 70), que forneceria todas as possibilidades de solução, com organização, numa representação diferenciada.

(Pesquisadora)

- "Existe um número máximo de viagens possíveis para o trator $A$ ?".

- "Se o trator $A$ fizer uma viagem, qual o número máximo de viagens que $B$ poderá fazer?".

- "E se A fizer duas viagens?".

Com esses questionamentos, as respostas dos alunos, após o consentimento de todos, iam sendo organizadas até a obtenção de toda a tabela. Examinando essa tabela, eles perceberam que as soluções possíveis estavam disponíveis e concordaram:

- "Agora ficou fácil!".

- "Assim é bem mais fácil, mas eu nunca ia ter essa ideia".

A solução algébrica desse problema também foi discutida, mas apesar de todos os questionamentos que indicariam os elementos para utilização dessa estratégia, os alunos se mostraram menos à vontade com esse tipo de resolução. Eles relataram dificuldade em "utilizar letras na resolução" e, por isso, preferiam a resolução anterior. 
No Problema 2, não houve grandes dificuldades para a compreensão. Eles entenderam a situação, porém, muitos disseram não saber como chegar à resposta. Alguns alunos mencionaram que um obstáculo foi não saber a que número "quinquagésimo" se referia, como já havíamos observado.

Os alunos identificaram que os segmentos aumentavam $1 \mathrm{~cm}$ a cada etapa e partiu deles a ideia de separar a medida dos segmentos horizontais da medida dos verticais. Eles indicaram que se tratava da formação de duas progressões aritméticas, mas essa informação não garantia a resolução do problema, devido aos comentários posteriores.

- "A gente sabe que é uma PA, mas não sabe fazer conta com PA. "

- "Como é mesmo a fórmula da PA?"

- "O que é o $a_{n}$ ?"

Incentivados a não se prenderem à utilização de fórmulas, os alunos foram orientados a construir uma tabela para representar a situação. Com os questionamentos que seguiram a construção da tabela, eles puderam descrever de forma geral o comprimento de um segmento horizontal, e de um segmento vertical, em qualquer etapa do traçado da espiral.

Depois de concordarem sobre quais seriam os últimos segmentos horizontais e verticais a serem considerados, faltava fazer a soma de todos os comprimentos. Novamente, eles sentiram a necessidade de utilizar uma fórmula: a da soma dos termos de uma P.A. Muitos alunos ainda procuraram a fórmula no caderno, mas foram lembrados de que não usaríamos mais fórmulas naquele problema.

Alguns alunos iniciaram os cálculos para chegar à soma desejada, mas desistiram devido ao grande número de parcelas. Foi, então, que as discussões levaram a efetuar os cálculos, reagrupando os termos das sequências dois a dois.

A maioria dos alunos mencionou falta de tempo para concluir o Problema 3. Eles relataram que esse foi o motivo para não terem compreendido direito o que estava sendo pedido.

Esclarecidas as dúvidas, o debate sobre o problema se iniciou a partir da necessidade que os alunos sentiram em identificar as figuras que formavam o desenho. Assim, como alguns já tinham feito, os alunos decidiram que utilizar a malha quadriculada era a melhor maneira de reproduzi-lo. 
A partir da identificação das figuras geométricas, em todas as turmas, a primeira tentativa se baseou na utilização de fórmulas para o cálculo de áreas. Ao observar que os triângulos eram retângulos, houve, ainda, a tentativa de utilizar a relação do Teorema de Pitágoras. Dessa forma, os alunos encontraram grande dificuldade na resolução e resolveram, por eles mesmos, que deveriam usar outra estratégia.

Então, foram indicados alguns elementos para que os alunos prosseguissem na resolução por reconfiguração. Em duas turmas, os alunos conseguiram subdividir toda a figura em triângulos pequenos. Na outra, concordaram em utilizar um trapézio e um triângulo pequeno para formar quadrados.

A partir disso, a figura foi reanalisada, mas os alunos não conseguiram chegar espontaneamente na resposta correta. Apesar de identificar as novas figuras obtidas e de concordar que ficava mais fácil "enxergar" daquela forma, muitos elementos tiveram que ser acrescentados à discussão para que eles pudessem concluir a solução.

\subsection{Resultados Fase 2}

\subsubsection{Resultados Fase 2 - Etapa 1}

Conforme já detalhado no Capítulo 5, os problemas propostos na Prova II, com exceção do último, do domínio da Geometria, foram adaptados, de modo que os tipos de registro discutidos na Etapa 3 da primeira fase fossem utilizados como representação na resolução dos problemas.

Como resultado, vemos na Tabela 9 que as médias de pontos obtidos em cada questão ficaram mais elevadas que na Fase 1. Além disso, observamos uma maior frequência de pontuação acima de 1. 


\begin{tabular}{|c|c|c|c|c|c|c|}
\hline \multicolumn{7}{|c|}{ PROVA II } \\
\hline $\begin{array}{c}\text { Pontos } \\
\text { atribuídos }\end{array}$ & 0 & 1 & 2 & 3 & 4 & Média \\
\hline Problema 1 & 5 & 6 & 6 & 1 & 0 & 1.17 \\
\hline Problema 2 & 7 & 8 & 0 & 3 & 0 & 0.95 \\
\hline Problema 3 & 8 & 7 & 0 & 3 & 0 & 0.89 \\
\hline
\end{tabular}

Tabela 9: Resultado Prova II - Fase 2 - Etapa 1

No primeiro problema, os grupos que receberam pontuação zero não iniciaram tentativas, nem preencheram a tabela proposta no enunciado.

Todos os grupos que obtiveram um ponto preencheram a tabela corretamente, mostrando compreensão sobre sua formação, assim como mostra a resolução do grupo G15, na Figura 36. Esses grupos deixaram apenas de escrever a última linha, que exigia uma conversão para o registro algébrico, algo que seria conveniente para o acesso mais direto à solução.

\begin{tabular}{|c|c|c|}
\hline Semana & $\mathrm{N}^{\circ}$ da nova revista & Último $n^{\circ}$ da coletânea \\
\hline 0 & 5802 & 4510 \\
\hline 1 & $5802+1$ & $4510+5$ \\
\hline 2 & $5802+2$ & $4510+10$ \\
\hline 3 & $5802+3$ & $4510+15$ \\
\hline 4 & $5802+4$ & $4510+20$ \\
\hline$\ldots$ & $5802+5$ & $4510+25$ \\
\hline$n$ & $5802+6$ & $4510+30$ \\
\hline
\end{tabular}

Figura 36: Solução do Grupo G15 - Problema 1, Prova II

Por outro lado, todos os grupos que alcançaram a pontuação 2 preencheram a tabela corretamente, inclusive determinando as equações que descrevem o número da revista em função da semana de publicação. Esses grupos deixaram apenas de concluir a resolução, por não identificarem a relação entre as expressões encontradas, não obtendo a solução correta, como no caso do grupo G8, que mostramos na Figura 37. 


\begin{tabular}{|c|c|c|}
\hline Semana & $\mathbf{N}^{\circ}$ da nova revista & Último $\mathbf{n}^{\mathbf{0}}$ da coletânea \\
\hline 0 & 5802 & 4510 \\
\hline 1 & $5802+1$ & $4510+5$ \\
\hline 2 & $5802+2$ & $4510+10$ \\
\hline 3 & $5802+3$ & 451011 \\
\hline 4 & $5802+4$ & $4510+20$ \\
\hline$\ldots$ & $5802+8$ & 4 \\
\hline$n$ & $5802+n$ & $40+5 \cdot 5$ \\
\hline
\end{tabular}



Figura 37: Solução do Grupo G8 - Problema 1, Prova II

Por fim, o grupo G16, que obteve a maior pontuação, preencheu a tabela corretamente, sem a generalização, mas conseguiu chegar na resposta correta. A explicação sobre a maneira como resolveram não está clara, porém, resumidamente, observamos que os alunos perceberam que o número da nova revista deveria ser igual ao último número da coletânea e, além disso, que o último número da coletânea sempre seria um múltiplo de cinco. Assim, procedendo por tentativas, testaram números de semanas que resultavam num número da nova revista múltiplo de cinco.

No Problema 2, novamente, não obtiveram pontos aqueles grupos que não preencheram ou preencheram incorretamente a tabela. Da mesma forma como no problema anterior, receberam um ponto os grupos que completaram adequadamente a tabela, mas não concluíram a solução. Os resultados desse problema são exibidos na tabela a seguir.

\begin{tabular}{|c|c|c|c|c|c|c|}
\hline \multicolumn{7}{|c|}{ PROVA II } \\
\hline $\begin{array}{c}\text { Pontos } \\
\text { atribuídos }\end{array}$ & 0 & 1 & 2 & 3 & 4 & Média \\
\hline Problema 2 & 7 & 8 & 0 & 3 & 0 & 0.95 \\
\hline
\end{tabular}

Tabela 10: Resultado Problema 2 - Fase 2 - Etapa 1 
Em geral, esses grupos, mesmo não escrevendo o número de cartas em um castelo de $p$ níveis, mostraram compreender que o número total de cartas do castelo seria obtido pela soma do número de cartas em cada nível. Aliás, mostraram ainda compreender a maneira como o número de cartas aumenta em cada nível acrescentado em um castelo, como vemos na solução do grupo G5, na Figura 38.

\begin{tabular}{|c|c|c|}
\hline Nivel & $\mathbf{N}^{\circ}$ de cartas & $\mathbf{N}^{\circ}$ de cartas como uma soma \\
\hline 1 & 2 & 2 \\
\hline 2 & 7 & $2+5$ \\
\hline 3 & 15 & $2+5+8$ \\
\hline 4 & 26 & $2+5+8+14$ \\
\hline 5 & 40 & $2+5+8+11+14$ \\
\hline 6 & 61 & $2+5+8+11+14+14+14$ \\
\hline$\ldots$ & 85 & \\
\hline$p$ & & \\
\hline
\end{tabular}

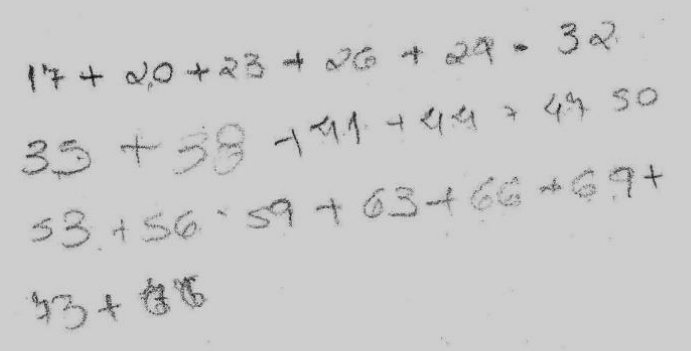

Figura 38: Solução do Grupo G5 - Problema 2, Prova II

Dois desses grupos tentaram obter o número de cartas do vigésimo quinto nível por meio da fórmula do termo geral de uma progressão aritmética, no entanto, não utilizaram corretamente a razão da P.A.

Esse procedimento não havia sido considerado na análise a priori. Uma possibilidade de solução seria, portanto, observar a formação de uma progressão aritmética de razão 3 , iniciando em 2, a partir do preenchimento da tabela. Com a fórmula do termo geral poderiam calcular o número de cartas do último nível: a $25=2$ $+(25$ - 1). $3=74$. Em seguida, pela soma dos termos de uma P.A., chegariam que o número total de cartas num castelo de 25 níveis seria a soma do número de cartas de cada nível, logo, encontrariam a solução correta, 950. 
Já os grupos aos quais atribuímos três pontos preencheram corretamente a tabela e chegaram à solução sem fazer a conversão do registro numérico para o registro algébrico. Todos eles, percebendo que a cada nível adicionado eram acrescentadas três cartas ao número de carta do nível anterior, escreveram o número de cartas de cada nível, até o $25^{\circ}$ e, por fim, efetuaram a adição de todos os números, apenas com tratamentos no registro numérico, como mostra a resolução do grupo G11, na Figura 39.

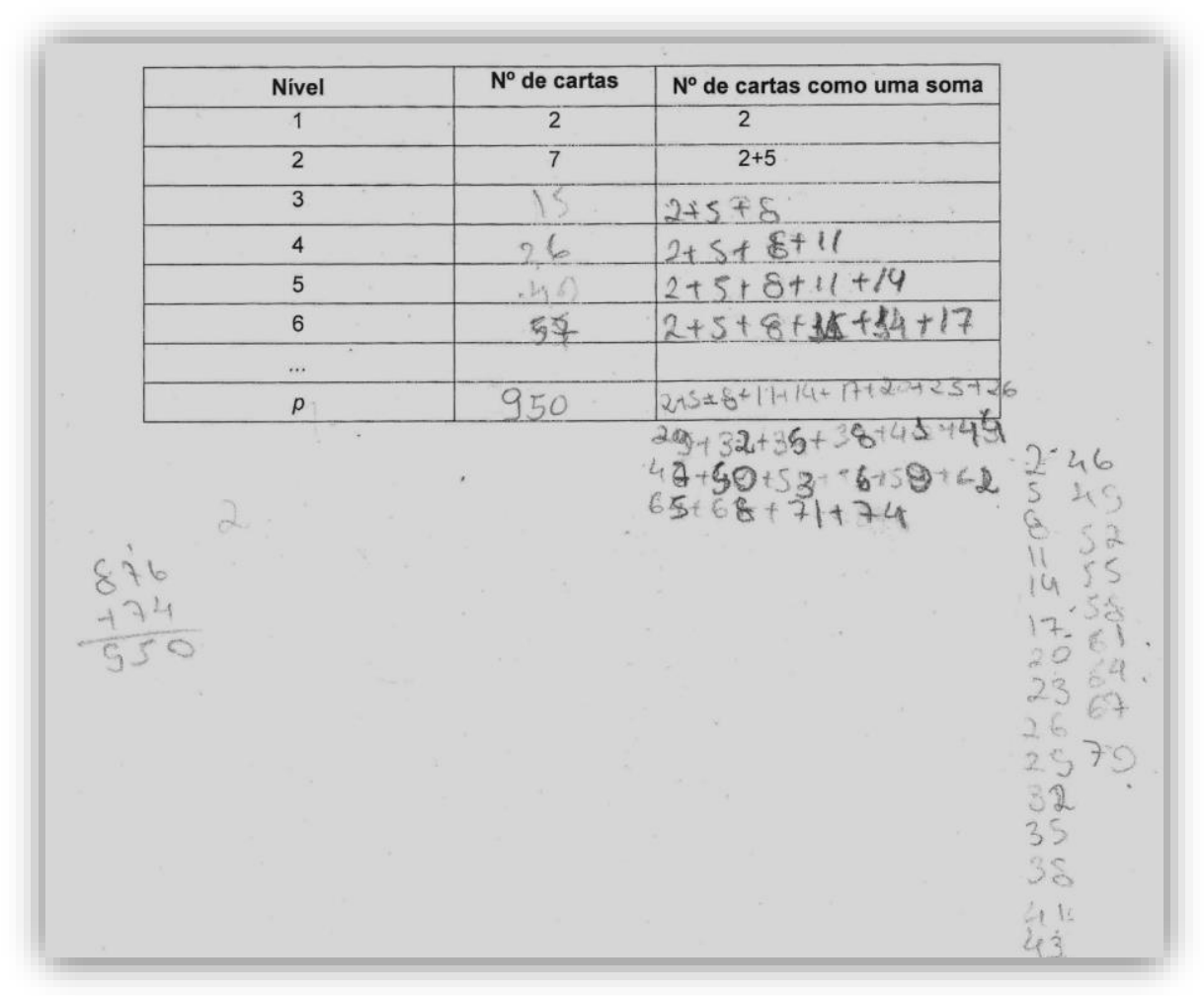

Figura 39: Solução do Grupo G11 - Problema 2, Prova II

Somente o grupo $\mathrm{G} 10$, que também obteve 3 pontos, utilizou corretamente a fórmula do termo geral da P.A. e descobriu o número de cartas do último nível. No entanto, prosseguiu com o registro numérico para concluir a solução (Figura 40), com o número exato de cartas do castelo de 25 níveis. Apesar disso, o grupo não explicou os procedimentos utilizados. 


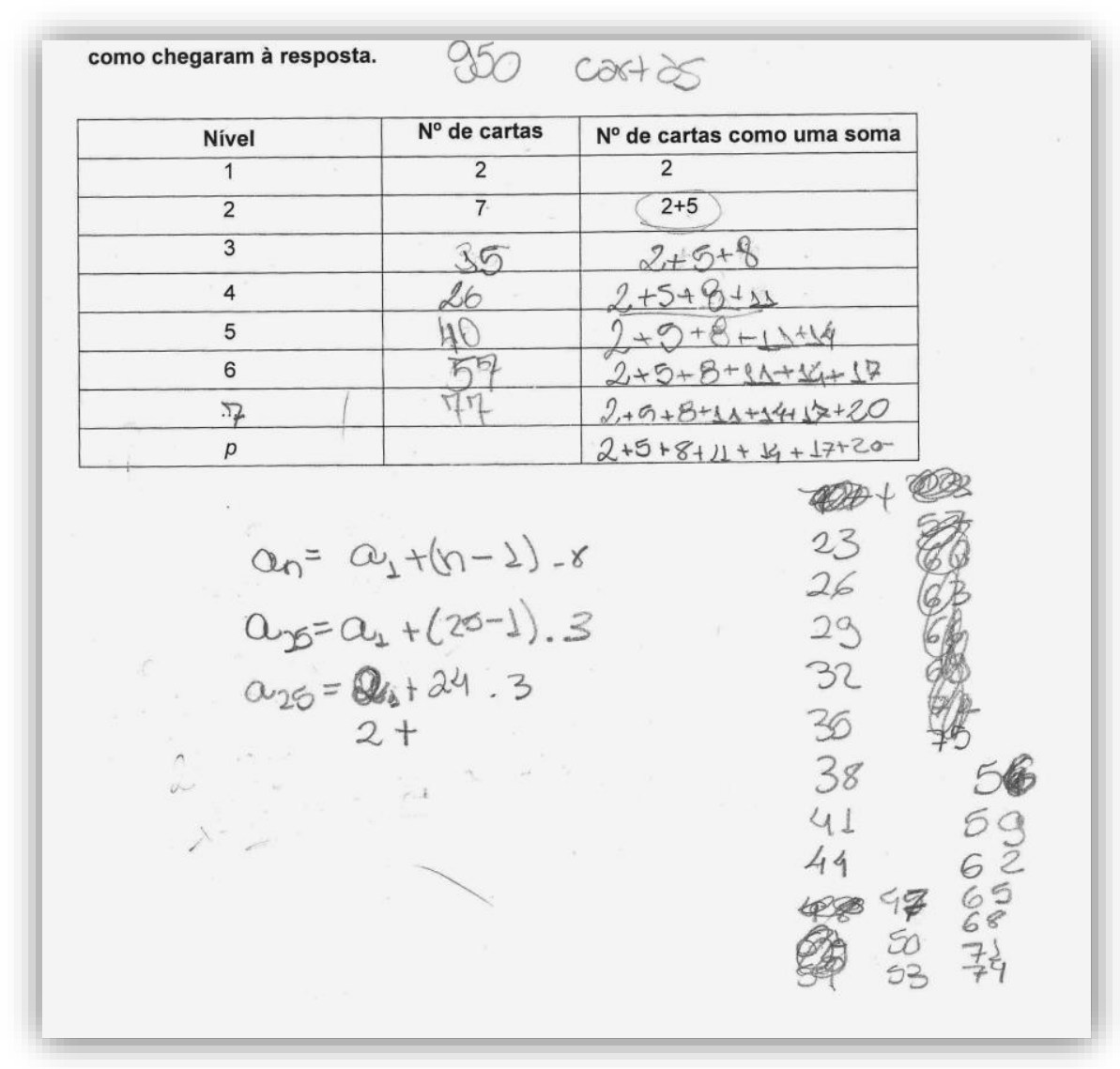

Figura 40: Solução do Grupo G10 - Problema 2, Prova II

Nos dois problemas, a presença das tabelas pode ter influenciado a compreensão das situações. Percebemos que, nesses problemas, os grupos mostraram informações mais relevantes que nas soluções da fase anterior, o que pode ter sido favorecido pela organização do registro numérico.

$\mathrm{Na}$ Tabela 11, vemos a pontuação geral para o Problema 3.

\begin{tabular}{|c|c|c|c|c|c|c|}
\hline \multicolumn{7}{|c|}{ PROVA II } \\
\hline $\begin{array}{c}\text { Pontos } \\
\text { atribuídos }\end{array}$ & 0 & 1 & 2 & 3 & 4 & Média \\
\hline Problema 3 & 8 & 7 & 0 & 3 & 0 & 0.89 \\
\hline
\end{tabular}

Tabela 11: Resultado Problema 3 - Fase 2 - Etapa 1

Nesse problema, todos os grupos que não obtiveram pontuação, ou não apresentaram solução, ou apresentaram solução incorreta sem explicações, sem satisfazer as condições do enunciado como no caso do grupo G12, exibido na Figura 41. 


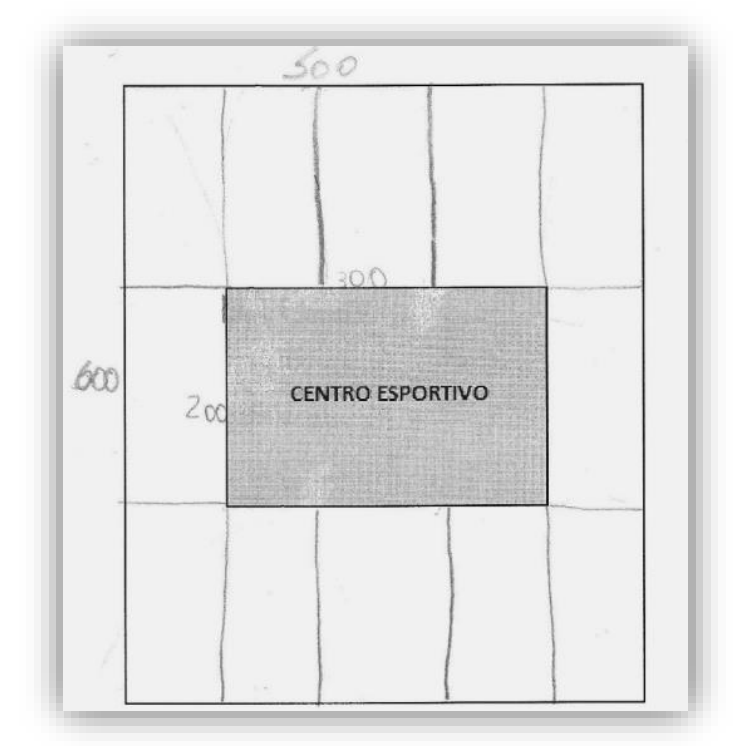

Figura 41: Solução do Grupo G12 - Problema 3, Prova II

Os grupos que receberam um ponto foram avaliados por atender, mesmo que parcialmente, a alguma das determinações do enunciado.

Quatro deles realizaram a conversão do registro em língua natural (enunciado) para o registro numérico ao calcular a área de cada parte que seria solução. No entanto, esses grupos não exibiram o desenho, como era solicitado no enunciado. Temos um exemplo desse tipo de solução na Figura 42, a solução do grupo G14.



Figura 42: Solução do Grupo G14 - Problema 3, Prova II 
Um outro grupo exibiu a divisão da figura em seis partes que, como pedia o enunciado, eram acessíveis ao centro esportivo. Por outro lado, as partes desenhadas não satisfaziam as condições de terem o mesmo formato e mesmas dimensões, como vemos na solução do grupo G6, reproduzida abaixo, na Figura 43.

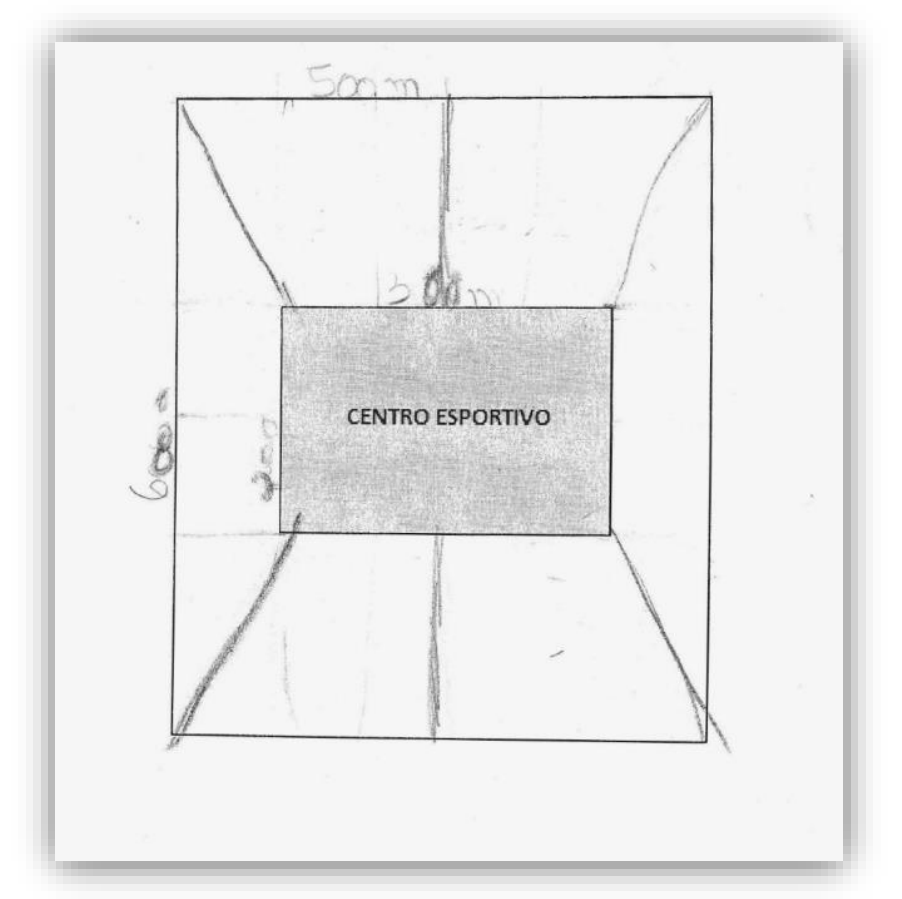

Figura 43: Solução do Grupo G6 - Problema 3, Prova II

Dois desses grupos (G13 e G16) iniciaram o desenho com a decomposição da figura em quadrados de mesma área. Eles utilizaram, como previsto na análise a priori, os lados do retângulo central para traçar paralelas que dividiriam o terreno ao seu redor. Mostraram, inclusive, por meio de cálculos e indicação na figura, a medida dos lados desses quadrados (Figura 44). 




Figura 44: Solução do Grupo G16 - Problema 3, Prova II

Os alunos desses grupos uniram os quadrados obtidos para solucionar o problema. As partes consideradas estão de acordo com o enunciado no que diz respeito ao acesso ao centro esportivo, porém, apesar de terem a mesma área, não têm o mesmo formato.

A partição correta foi apresentada por três grupos que procederam da mesma forma: inicialmente, traçaram quadrados de medidas de lados iguais a partir de retas paralelas aos lados do retângulo. A única falha foi não ter explicado o processo de solução, como na resolução do grupo G1 (Figura 45). 


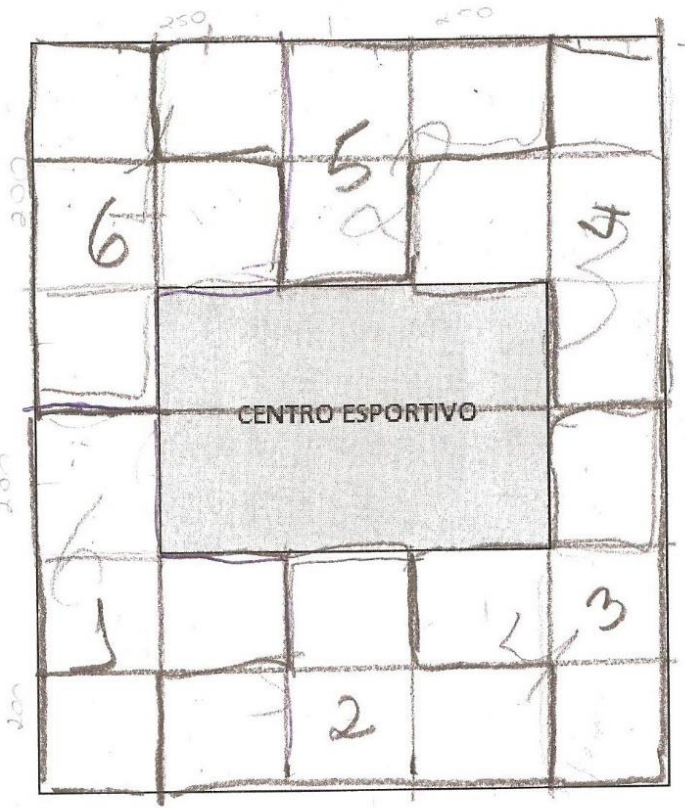

Figura 45: Solução do Grupo G1 - Problema 3, Prova II

\subsubsection{Resultados Fase 2 - Etapa 2}

Para os dois primeiros problemas da Prova II, as discussões previstas para esta etapa ficaram restritas ao preenchimento da tabela contida no enunciado.

Os alunos relataram ter sido mais difícil compreender a situação proposta no Problema 1, apesar disso, compreenderam como a tabela deveria ser preenchida. Alguns grupos, mesmo com a tabela completa, não compreenderam o problema. Outros, comentaram que a tabela facilitou o entendimento do enunciado, mas não concluíram a resolução, por não saberem interpretar os dados obtidos.

Num primeiro momento, então, as dúvidas sobre o enunciado foram esclarecidas, juntamente com a interpretação dos dados da tabela. A conclusão não foi adquirida facilmente pelos alunos, a não ser na turma do grupo G16, que não havia exibido a explicação clara sobre a solução. Um dos integrantes do grupo descreveu: 
- "Eu vi que na última coluna, todos os números terminavam em 0 e 5. Entendi que a resposta seria quando encontrasse números iguais nas duas colunas. $\mathrm{Na}$ segunda coluna, 5802 tinha que ser somado com números que terminassem com 3 ou 8 para dar um número que terminasse com 0 ou 5. Fui testando e cheguei em 323."

Com essa explicação, os alunos dessa turma, precisavam verificar se a resposta estava correta. Para isso, fizeram a substituição de 323 nas expressões obtidas e viram que o resultado obtido era o mesmo. A partir disso, foi discutido que esse procedimento estava relacionado com a resolução de uma equação e, assim, a resposta também poderia ser obtida.

O segundo problema pareceu mais fácil para os alunos, já que eles relataram ter compreendido o problema e o preenchimento da tabela. Alguns disseram que, com a tabela, foi mais fácil de organizar a contagem, mas teriam resolvido também sem ela.

O preenchimento da tabela previa a generalização do número de cartas em um castelo como a soma do número de cartas em cada nível, dado um número $p$ de níveis. Nas análises das soluções, vimos que nenhum aluno efetuou a conversão do registro numérico para o algébrico. As discussões deles na Etapa 2 também não foram suficientes para que o conseguissem fazer. Eles preferiram seguir no registro numérico e, com o auxílio dos outros colegas, tentaram relembrar o procedimento utilizado para a soma no Problema 2 da prova anterior. Assim, conseguiram obter a resposta correta.

Os grupos relataram falta de tempo para concluir a solução do Problema 3. A discussão sobre esse problema se iniciou com a tentativa de calcular a medida da área que deveriam obter. A tentativa foi considerada, mas com o destaque para o que era pedido no enunciado: desenhar as 6 partes.

Os integrantes dos grupos que utilizaram a reconfiguração pela divisão em quadrados, durante o debate, propuseram esse procedimento, pois ele havia sido válido no problema geométrico da prova anterior. Ainda mais, podemos mencionar a fala de um dos alunos:

- "Um lado tem $600 \mathrm{~m}$ e o outro $500 \mathrm{~m}$. Os quadrados podem ter $100 \mathrm{~m}$ de lado e a gente faz fileiras com 5 quadrado." 
Com o papel quadriculado, alguns alunos se prontificaram a dividi-los nas 6 partes desejadas. Eles foram lembrados a todo momento de que deveriam atender às condições colocadas no enunciado. Assim, em todas as turmas os alunos conseguiram obter a resposta correta, com o consenso de todos.

\subsection{Resultados Fase 3}

\subsubsection{Resultados Fase 3 - Etapa 1}

Na Fase 3, os problemas não estavam acompanhados da sugestão de uso de um tipo específico de registro, para que pudéssemos verificar a maneira como os sujeitos reutilizariam os tipos de representações presentes nas discussões sobre os problemas anteriores (nas devolutivas) e na Prova II.

\begin{tabular}{|c|c|c|c|c|c|c|}
\hline \multicolumn{7}{|c|}{ PROVA III } \\
\hline $\begin{array}{c}\text { Pontos } \\
\text { atribuídos }\end{array}$ & 0 & 1 & 2 & 3 & 4 & Média \\
\hline Problema 1 & 14 & 3 & 1 & 0 & 0 & 0.28 \\
\hline Problema 2 & 6 & 7 & 2 & 3 & 0 & 0.83 \\
\hline Problema 3 & 9 & 1 & 2 & 6 & 0 & 1.28 \\
\hline
\end{tabular}

Tabela 12: Resultado Prova III - Fase 3 - Etapa 1

Dos grupos que não obtiveram pontuação no Problema 1, nove não exibiram tentativas. Os outros mostraram o início de uma pesquisa de valores de moedas cuja soma era 20 , mas, a atribuição de pontos, conforme a análise a priori, considerava a necessidade de compreensão do produto 1.

A maior parte desses grupos procedeu por tentativas utilizando o registro numérico, da mesma maneira que haviam conduzido as soluções na Fase 1, sem organização ou produção espontânea de algum tipo das representações já discutidas. O grupo G11, porém, se dedicou a dispor ordenadamente suas tentativas, como na Figura 46, separando em colunas: quantidade de moedas consideradas, valor da moeda e valor total obtido. O que demonstra a tentativa de uma organização das informações necessárias para a obtenção do resultado. 


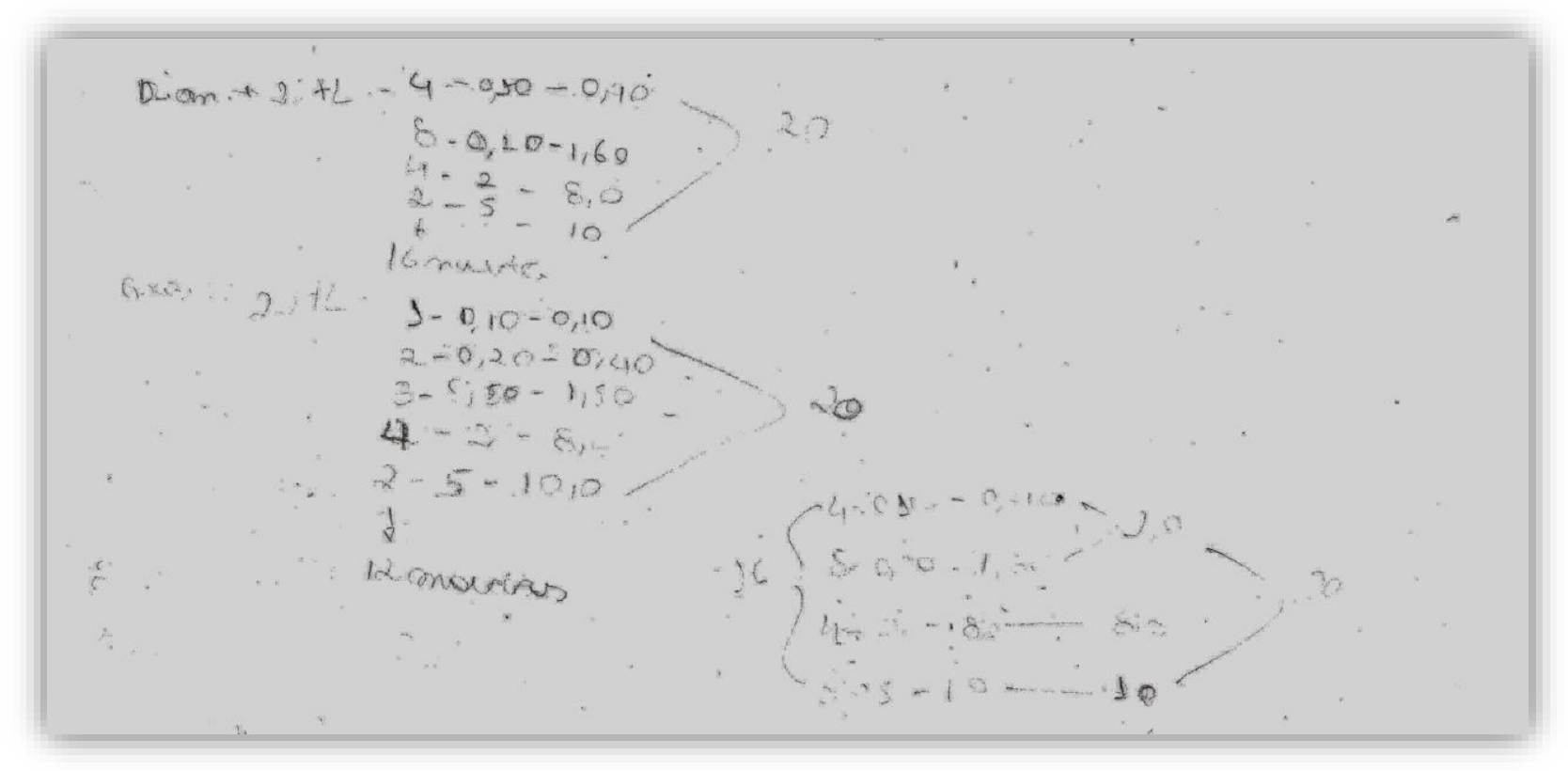

Figura 46: Solução do Grupo G11 - Problema 1, Prova III

Os grupos que obtiveram um ponto também conduziram a solução apenas por tentativas que, mesmo sem organização ou explicações, revelaram a compreensão de que deveriam conseguir 1 como produto dos valores das moedas.

Apenas um desses grupos, o G14, chegou a uma das possibilidades (Figura 47) utilizando 16 moedas e, a partir disso, assumiram que a outra possibilidade deveria considerar 20 moedas, mas não encontraram quais seriam as moedas. Ao final da resolução, o grupo fez apenas uma tentativa e admitiu que não conseguiu. Tal declaração pode ter relação com o que foi mencionado anteriormente: o procedimento de solução por meio de tentativas pode desmotivar os alunos na conclusão da resolução. 


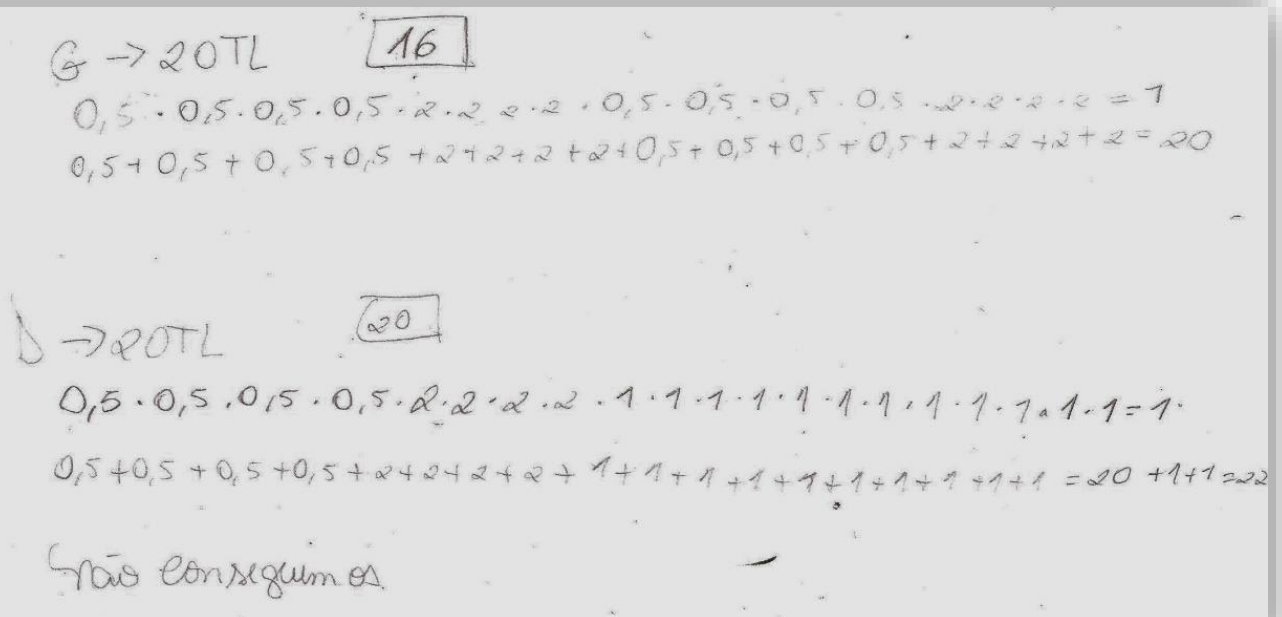

Figura 47: Solução do Grupo G14 - Problema 1, Prova III

O grupo G16, foi o único que recebeu 2 pontos. Apenas por tentativas, os alunos exibiram a solução correta, porém sem explicações. Vemos na Figura 48 que a verificação de que as moedas escolhidas satisfaziam as condições propostas no problema também não foi apresentada.

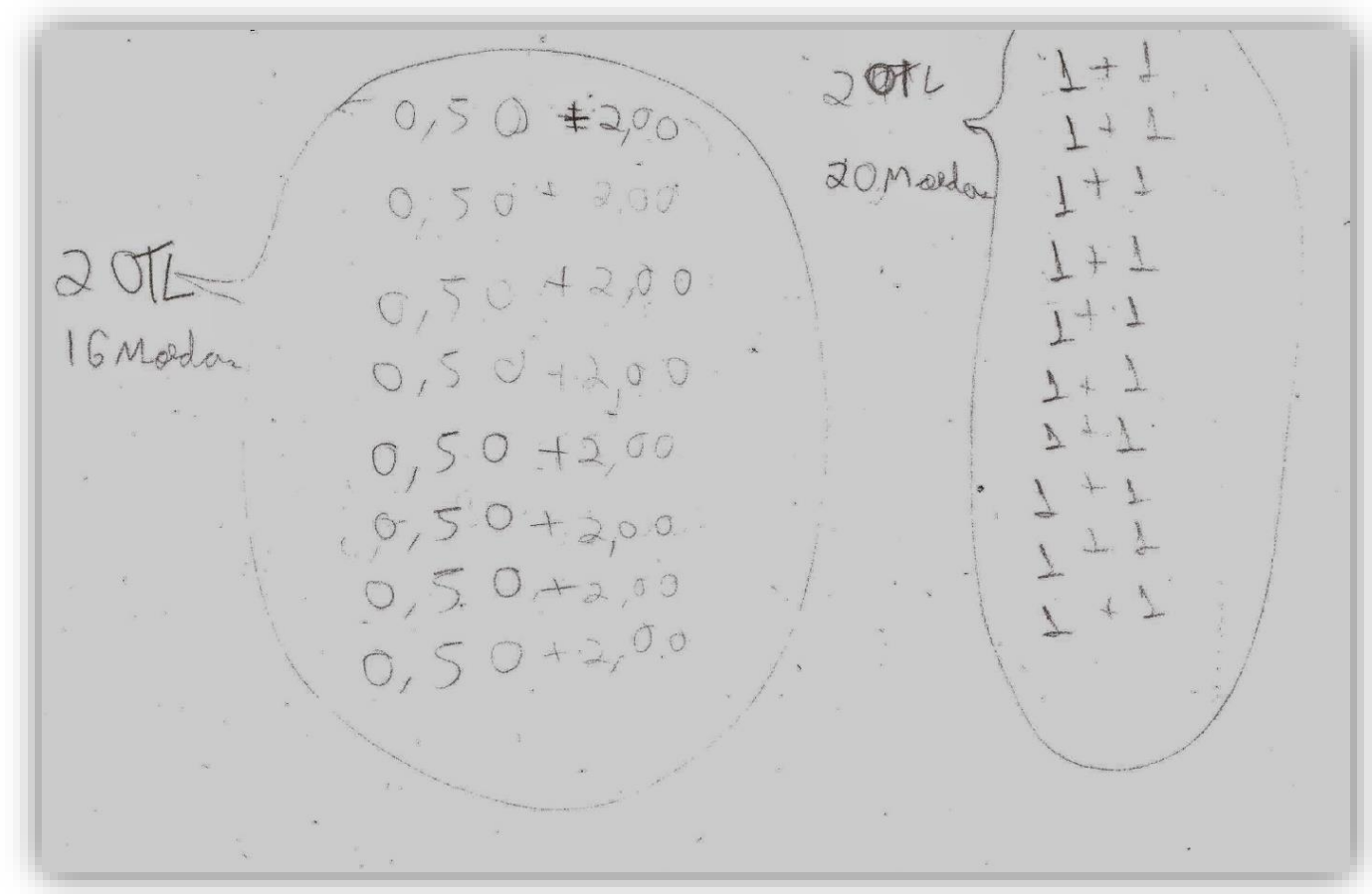

Figura 48: Solução do Grupo G16 - Problema 1, Prova III 
No Problema 2, os grupos que não pontuaram não responderam, nem exibiram qualquer tentativa de resolução. Já os grupos que obtiveram 1 ponto mostraram compreensão da situação apesar de terem cometido erros (cf. Tabela 13).

\begin{tabular}{|c|c|c|c|c|c|c|}
\hline \multicolumn{7}{|c|}{ PROVA III } \\
\hline $\begin{array}{c}\text { Pontos } \\
\text { atribuídos }\end{array}$ & 0 & 1 & 2 & 3 & 4 & Média \\
\hline Problema 2 & 6 & 7 & 2 & 3 & 0 & 0.83 \\
\hline
\end{tabular}

Tabela 13: Resultado Problema 2 - Fase 3 - Etapa 1

Todos esses grupos iniciaram a resolução pela conversão do registro figural para o registro numérico. Dois deles exibiram apenas a quantidade de cubos brancos e cinzas em cada andar apresentado nas figuras do enunciado. Em contrapartida, a maioria demonstrou preocupação em sistematizar as contagens e deduzir regularidades a partir delas.

Os grupos G2 e G8 organizaram os dados do enunciado em tabelas. No primeiro caso (Figura 49), o grupo fez a distinção entre cubos cinzas e brancos que eram acrescentados a cada andar da pirâmide. Na produção do registro numérico tabular, os alunos não consideraram os andares separadamente, então, podemos observar que cada linha da tabela mostra o aumento de cubos em dois andares da pirâmide. Talvez, por esse motivo, o grupo não tenha conseguido solucionar o problema, apesar de ter compreendido a formação das pirâmides.

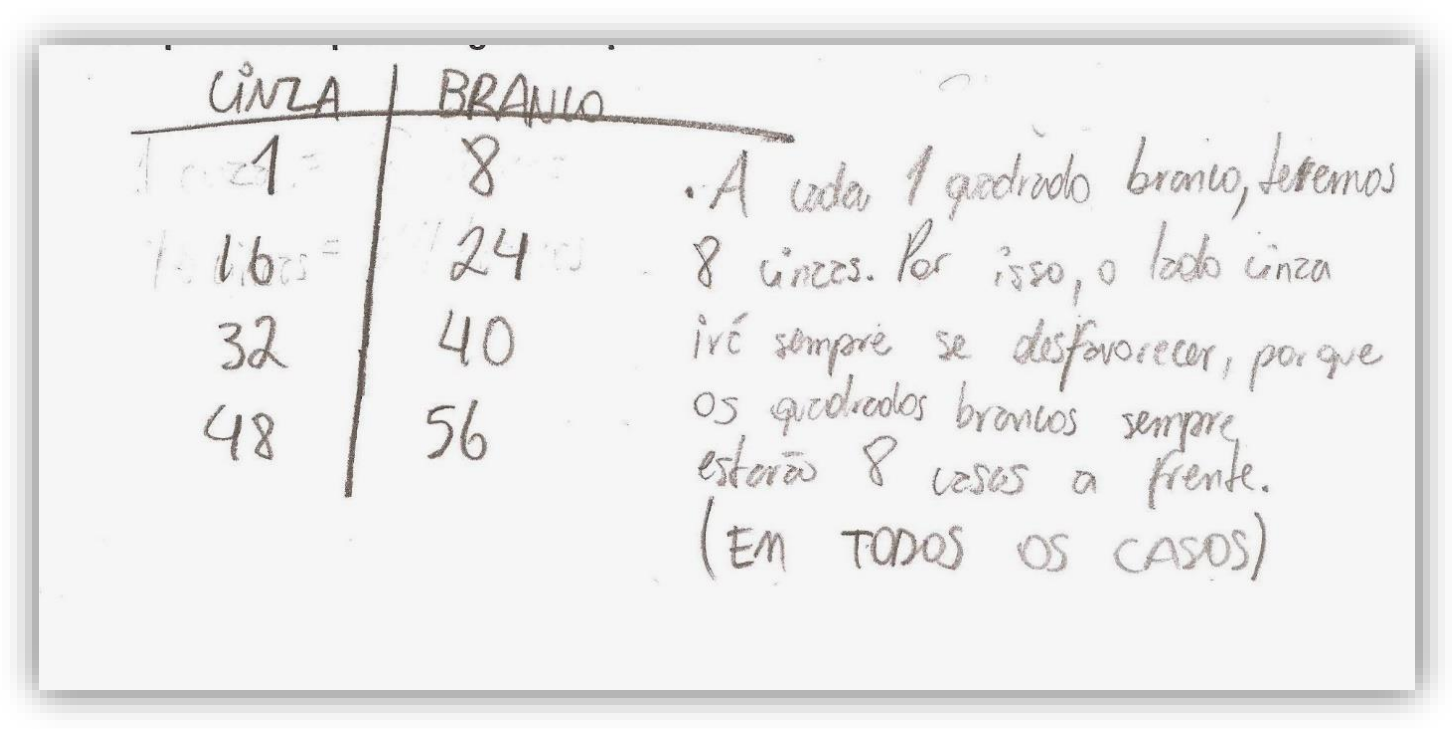

Figura 49: Solução do Grupo G2 - Problema 2, Prova III 
No segundo exemplo de solução utilizando registro tabular (Figura 50), o grupo construiu uma tabela considerando a quantidade de cubos de cada cor acrescentados a cada andar da pirâmide. No entanto, para responder às perguntas sobre a diferença entre a quantidade de cubos, efetuaram a soma dos números de cada coluna, o que resultava na contagem de cubos do último andar e não da pirâmide toda.

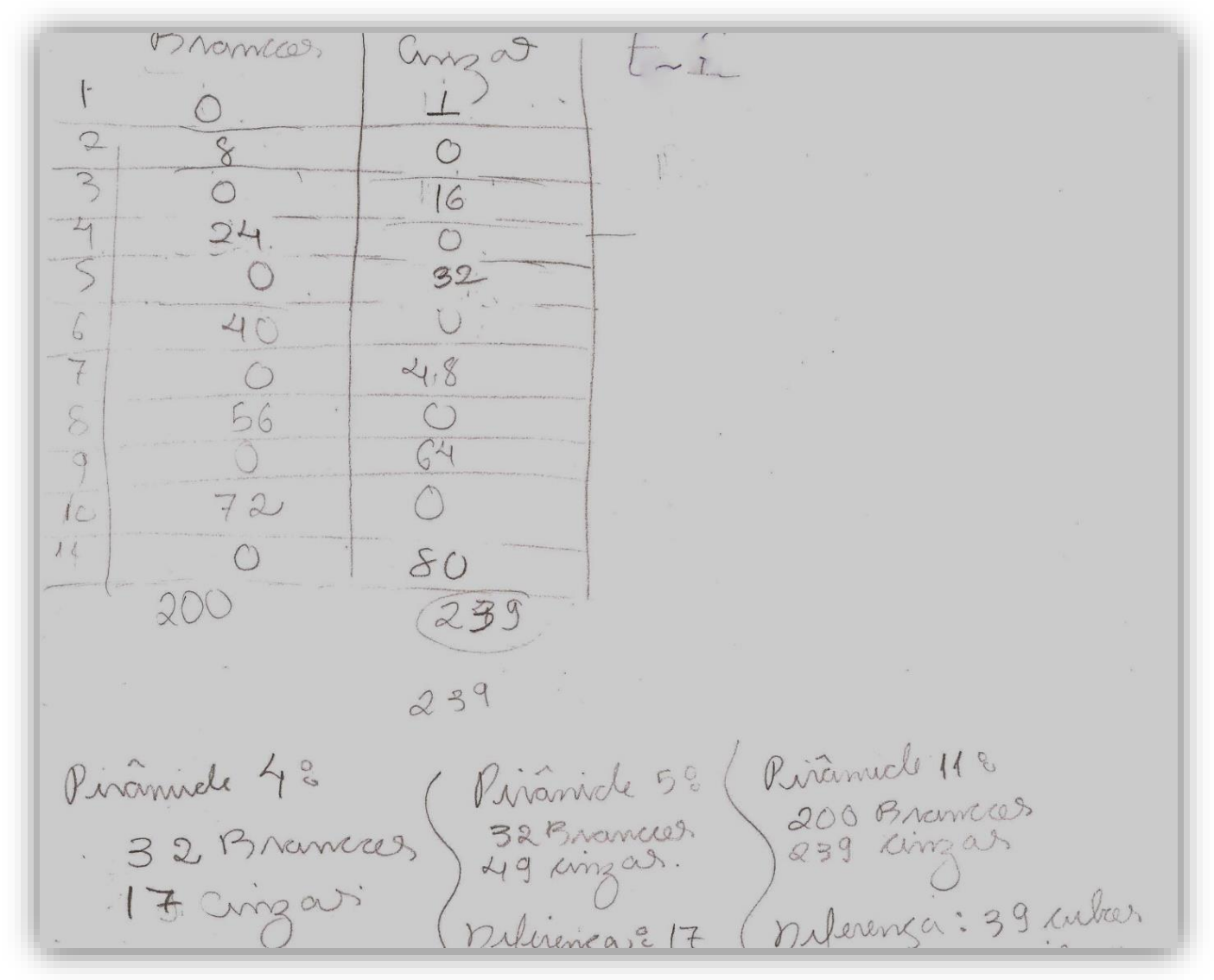

Figura 50: Solução do Grupo G8 - Problema 2, Prova III

Na resolução do grupo G13, encontramos diversas tentativas para organizar os dados do enunciado e, por fim, notamos uma resposta baseada num registro parecido com uma tabela (Figura 51). Os alunos iniciaram a produção do registro de modo conveniente, semelhante a uma das sugestões da análise a priori: considerando a quantidade total de cubos de cada cor em cada andar de uma pirâmide. Escreveram os dados corretamente, até uma pirâmide de quatro andares, mas, na pirâmide de cinco andares, escreveram apenas as quantidades de cubos brancos e cinzas que compunham a borda do quinto andar. 


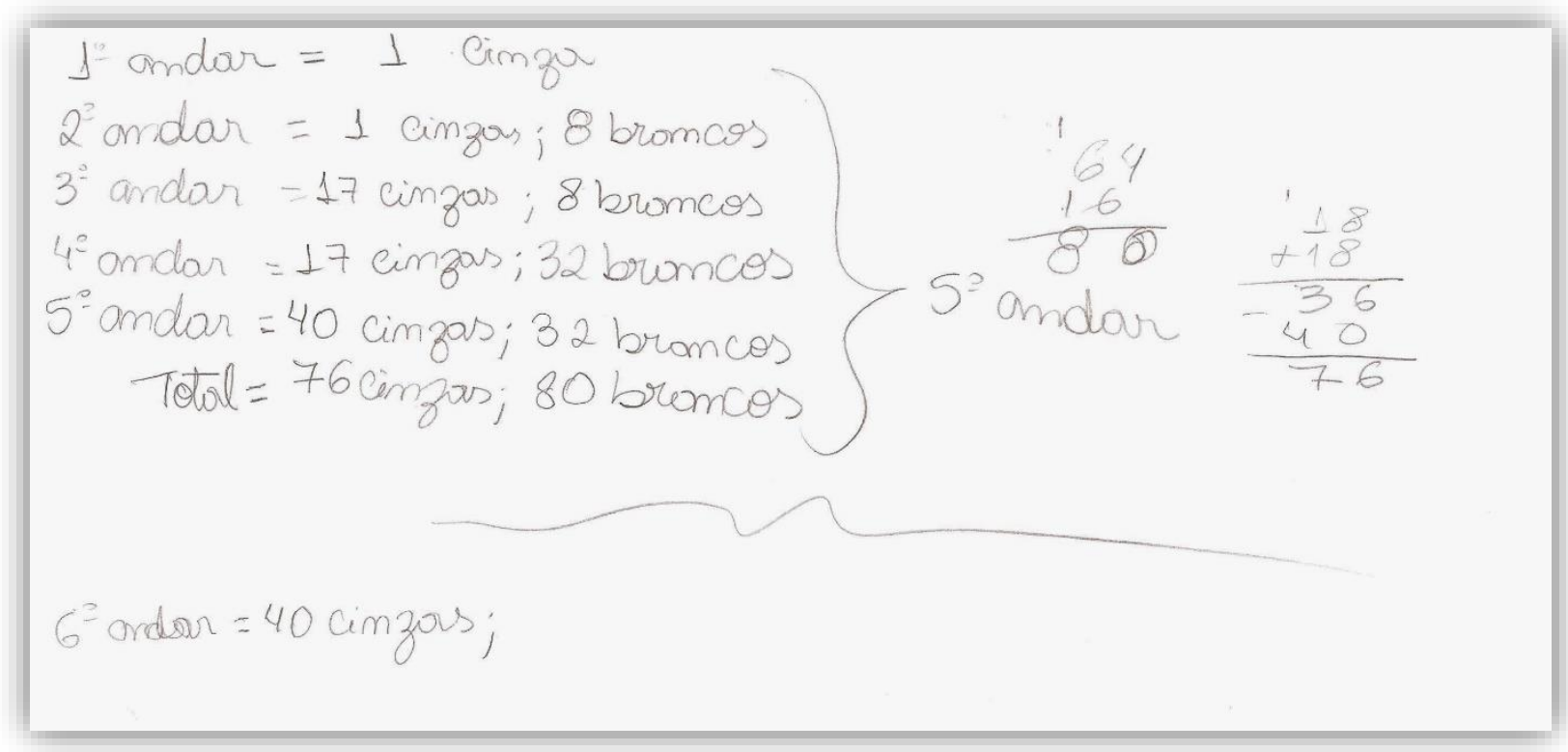

Figura 51: Solução do Grupo G13 - Problema 2, Prova III

O grupo G9, que alcançou pontuação 2, também tentou construir uma tabela de diversas maneiras e os alunos finalizaram com uma similar à que é proposta na análise a priori, porém sem a conversão para o registro algébrico.

Vemos que os dados contidos na tabela da Figura 52, a seguir, estão corretos, contemplando a quantidade de cubos brancos e cinzas em cada andar das pirâmides. Apesar disso, o grupo não concluiu o raciocínio.

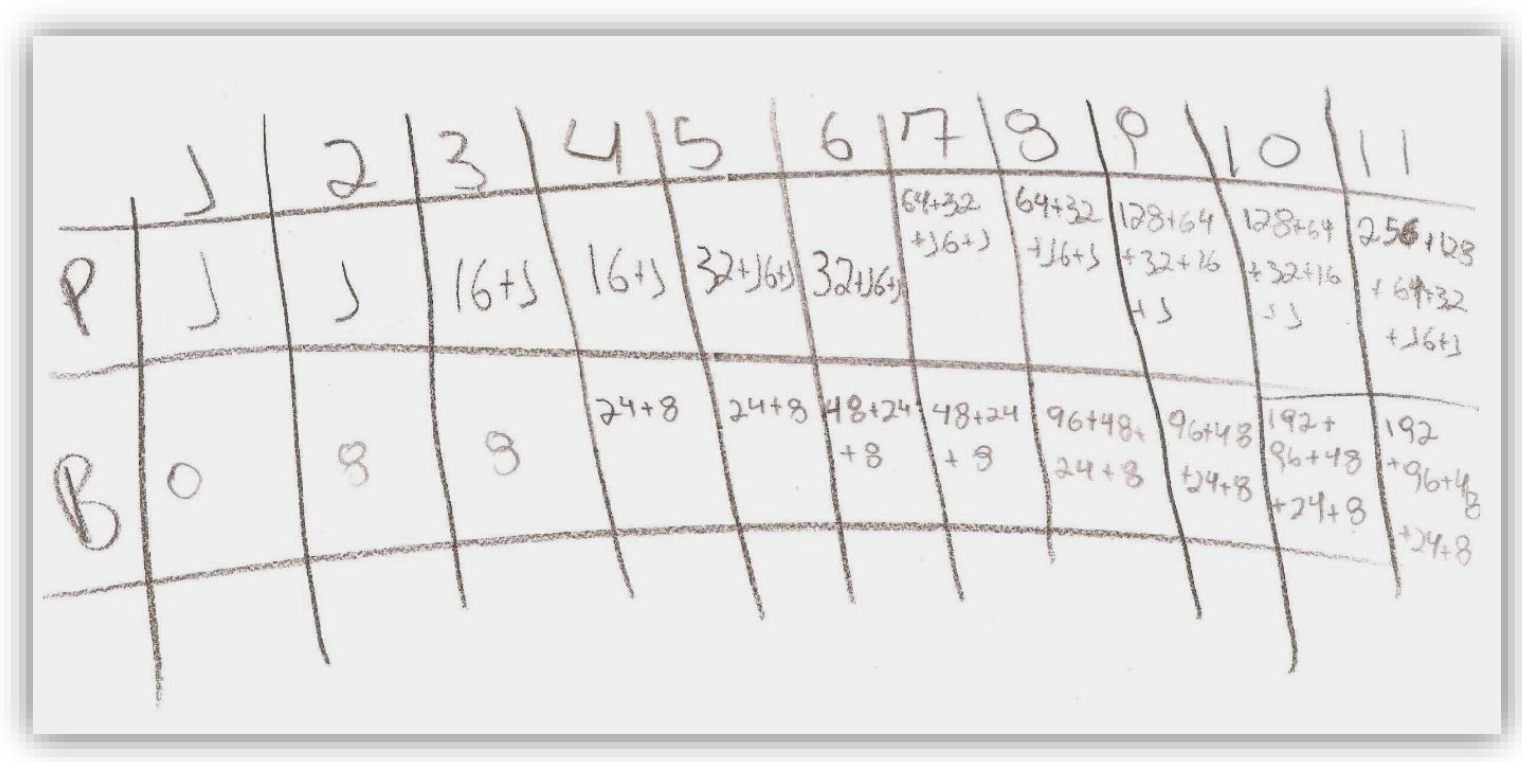

Figura 52: Solução do Grupo G9 - Problema 2, Prova III 
Na resolução desse problema, o grupo G10 considerou a contagem dos cubos na vertical, maneira essa que era prevista na análise a priori. Os alunos observaram, primeiramente, que cada andar da pirâmide possuía $n^{2}$ cubos no total, sendo $n$ um inteiro ímpar, e organizaram essa informação no que seria uma tentativa de formação de uma tabela. Em seguida, efetuaram uma soma e chegaram à quantidade total de cubos em pirâmides de 5 e 11 andares.

Por fim, eles calcularam a quantidade total de cubos cinzas nessas pirâmides, levando em conta que, por exemplo, nos 11 andares da pirâmide encontrariam 11 cubos cinzas centrais; depois a fileira com 16 cubos cinzas em 9 andares da pirâmide; a fileira de 32 cubos cinzas em 7 andares, e assim por diante. Vemos na Figura 53, fragmentos dessa resolução.
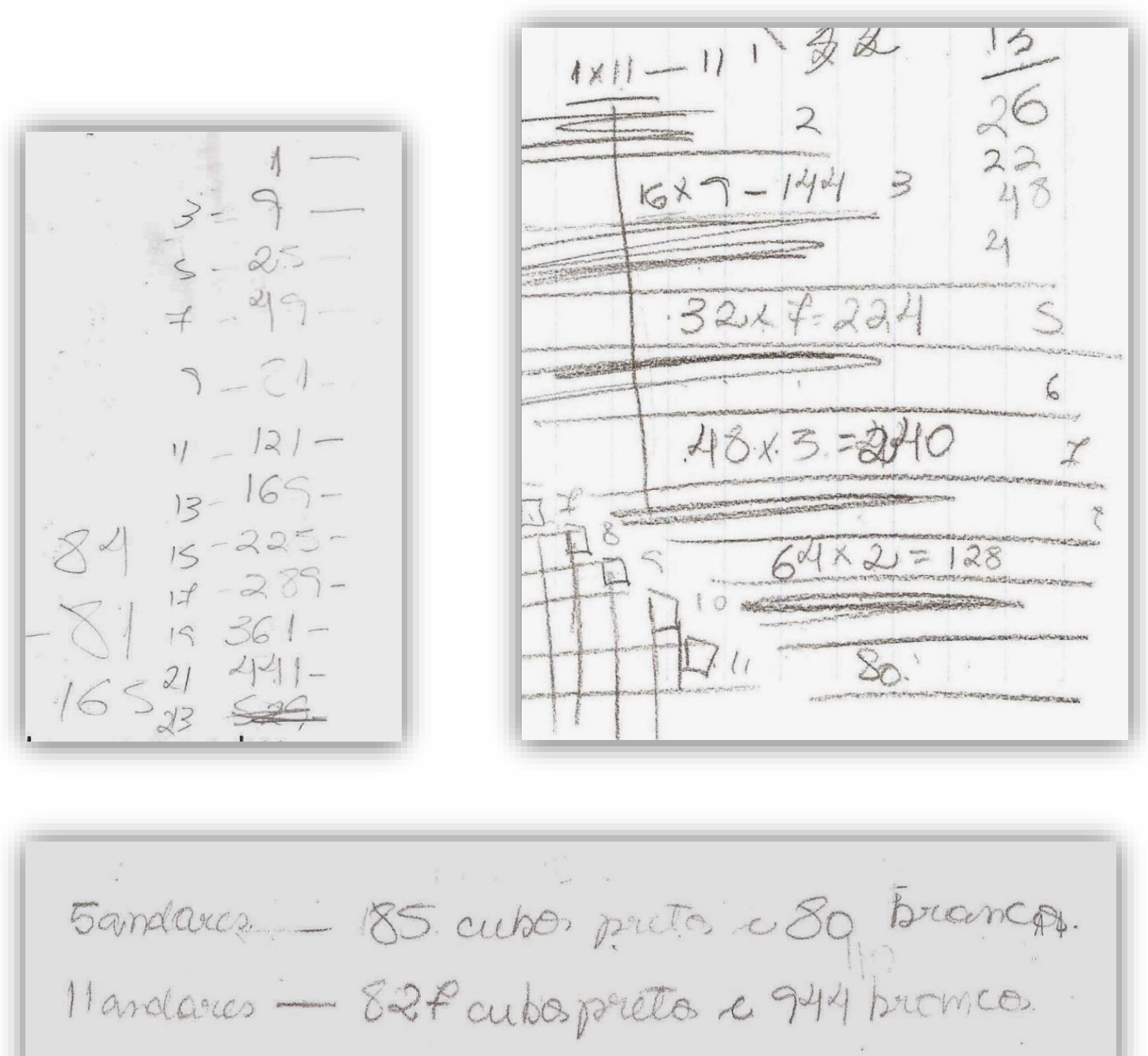

Figura 53: Solução do Grupo G10 - Problema 2, Prova III 
Como vimos, apesar de grande esforço, o grupo não calculou a diferença entre a quantidade de cubos ainda que houvessem encontrado os valores corretos das quantidades de cubos brancos e cinzas de uma pirâmide de cinco andares. Com isso, obtiveram 2 pontos.

O grupo G11, é o grupo ao qual foram atribuídos 3 pontos. Os alunos também efetuaram a contagem dos cubos verticalmente, e, diferente do anterior, respondeu corretamente que a diferença entre o número de cubos brancos e cinzas numa pirâmide de cinco andares é 5 .

Esses alunos procederam de maneira organizada no registro da quantidade de cubos em cada fileira de cada andar, depois de verificar que, num novo andar da pirâmide, a quantidade de cubos da borda superava em oito unidades a quantidade no andar anterior. A Figura 54 mostra parte da resolução, na qual eles obtiveram a diferença entre o número de cubos branco e cinzas na pirâmide de 5 andares a partir da contagem vertical dos cubos, porém não finalizaram a contagem para o caso da pirâmide de 11 andares.

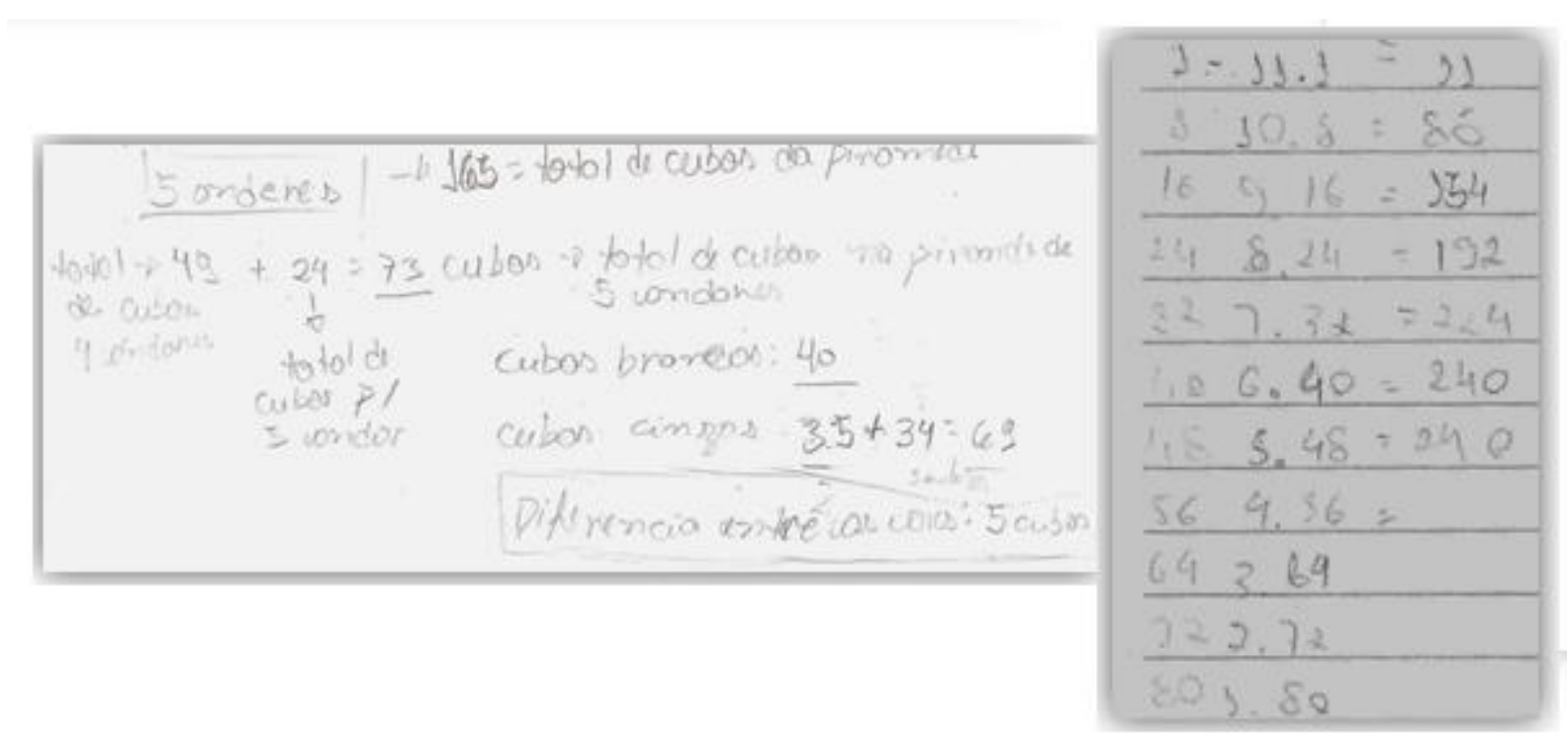

Figura 54: Solução do Grupo G11 - Problema 2, Prova III

Apesar da grande quantidade de grupos que não obtiveram pontos, o Problema 3 foi o mais pontuado entre os problemas de Geometria das três provas, como vemos na Tabela 14. 


\begin{tabular}{|c|c|c|c|c|c|c|}
\hline \multicolumn{7}{|c|}{ PROVA III } \\
\hline $\begin{array}{c}\text { Pontos } \\
\text { atribuídos }\end{array}$ & 0 & 1 & 2 & 3 & 4 & Média \\
\hline Problema 3 & 9 & 1 & 2 & 6 & 0 & 1.28 \\
\hline
\end{tabular}

Tabela 14: Resultado Prova III - Fase 3 - Etapa 1

Dentre os grupos com pontuação zero, apenas o G11 apresentou uma resposta. Os alunos desse grupo mostraram falha na apreensão perceptiva pois resolveram o problema considerando que o ponto $\mathrm{P}$ era ponto médio da base menor do trapézio. Eles traçaram um segmento perpendicular às bases e explicaram que aquele segmento dividia a figura em duas partes de mesma área, apesar de terem nomeado um dos vértices do trapézio como Q (Figura 55).

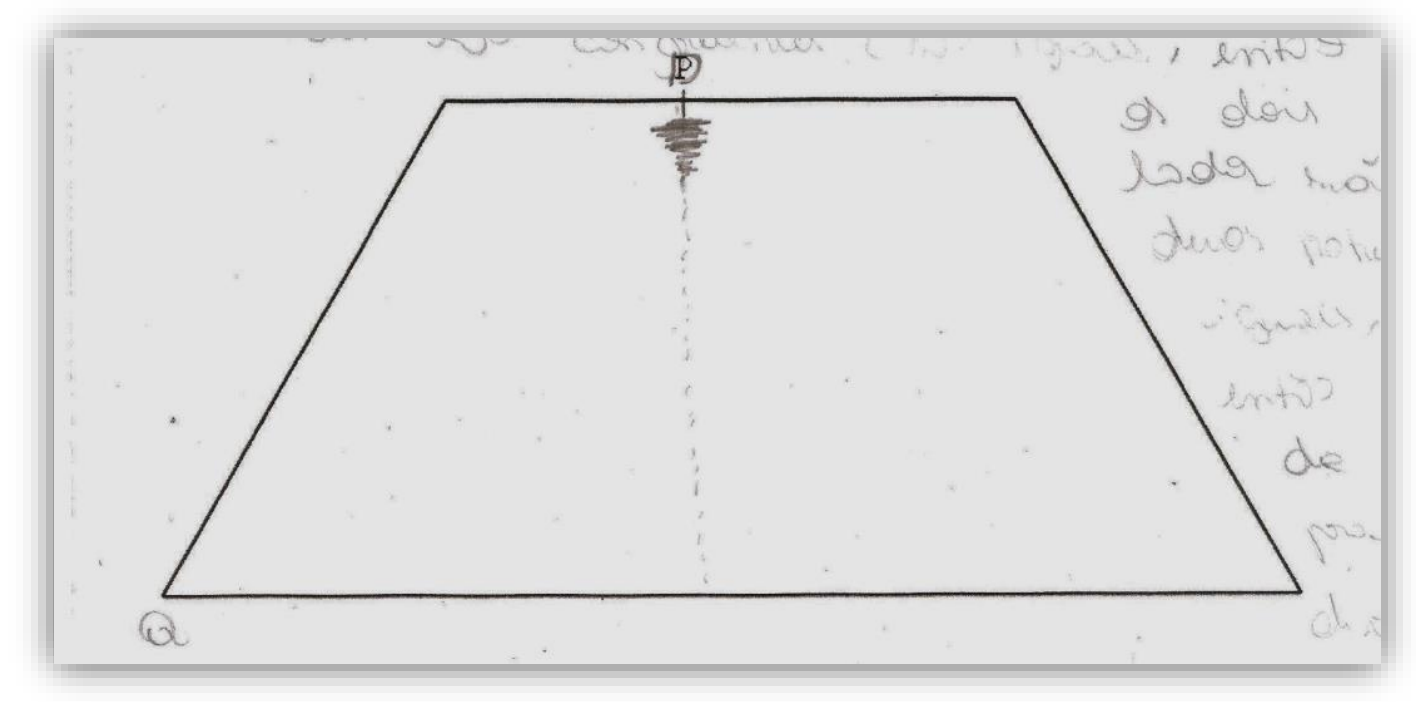

Figura 55: Solução do Grupo G11 - Problema 3, Prova III

O grupo G1, que obteve 1 ponto, efetuou algumas divisões na figura como, por exemplo, considerar o retângulo tomando perpendiculares que passam pelos vértices "superiores" do trapézio e as diagonais desse retângulo. Como podemos ver na figura abaixo, os alunos traçaram um segmento que parece ter sido visto, por eles, como solução, entretanto, não exibiram explicações. Tal representação figural dá indícios de uma apreensão operatória da figura. 


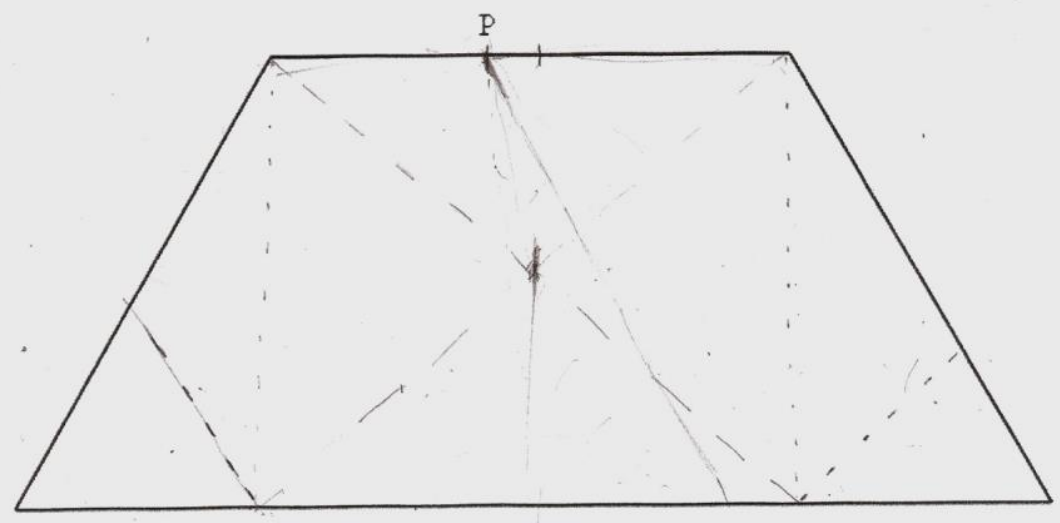

Figura 56: Solução do Grupo G1 - Problema 3, Prova III

Os dois grupos aos quais foram atribuídos dois pontos (G7 e G14) encontraram o ponto $Q$ a partir do traçado do segmento perpendicular às bases pelos seus pontos médios. O ponto está bem posicionado, no entanto, eles não dão explicações claras sobre como chegaram a ele, como ilustra a solução na Figura 57.

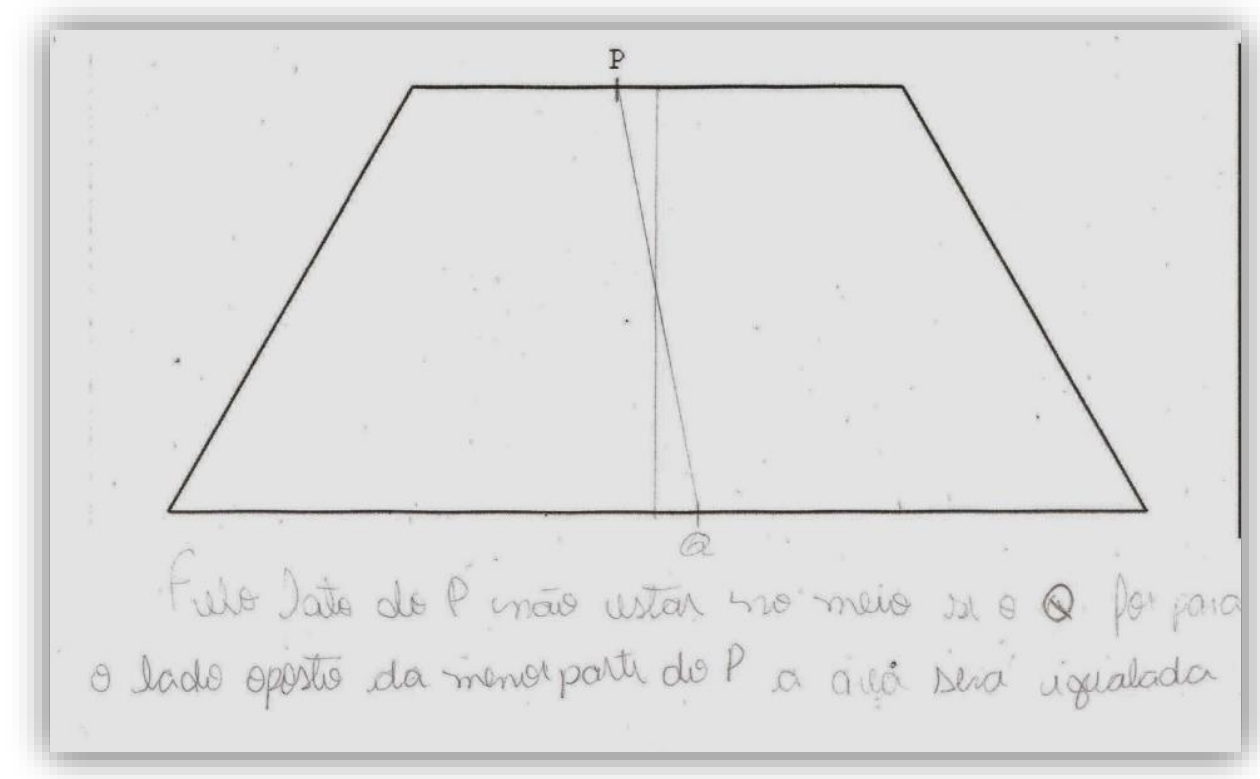

Figura 57: Solução do Grupo G14 - Problema 3, Prova III

Dos grupos que alcançaram três pontos, a maioria procedeu por transferência de medidas utilizando uma régua. Na Figura 58, vemos a solução dada pelos alunos 
do grupo G16: eles utilizaram a decomposição do trapézio em dois triângulos e um retângulo (apreensão operatória); indicaram todas as medidas, marcaram o ponto $Q$ corretamente, explicaram o procedimento utilizado, porém, não justificaram a igualdade das áreas das subfiguras. A ausência da justificativa sobre a igualdade das áreas fez com que todos esses grupos não atingissem a pontuação máxima.

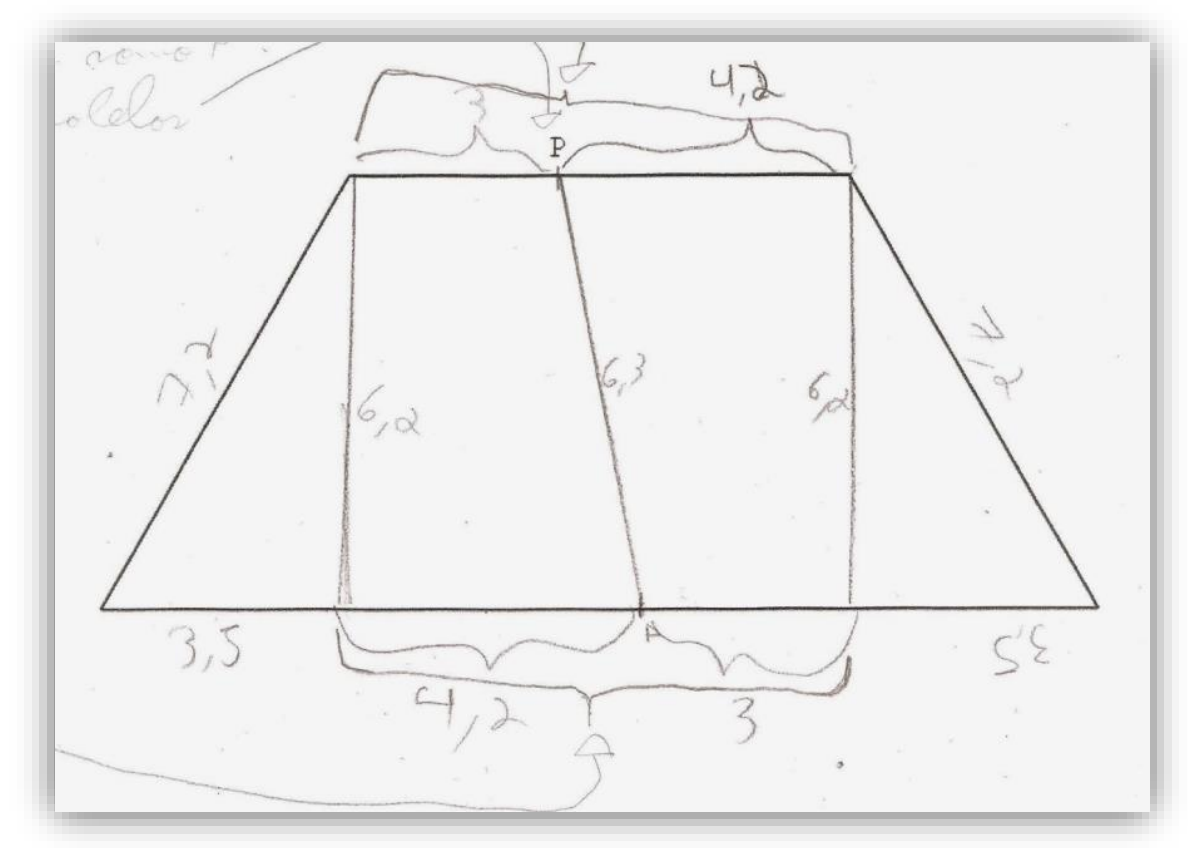

Figura 58: Solução do Grupo G16 - Problema 3, Prova III

O grupo G13 também utilizou a régua como instrumento de medida para encontrar a mediatriz das bases do trapézio e, diferente da solução anterior, não fez a divisão da figura em dois triângulos e um retângulo. Observamos que esses alunos transferiram a medida de $\mathrm{P}$ à mediatriz, da base menor para a base maior, para encontrar o ponto $Q$. Eles observaram a formação de dois triângulos retângulos "iguais", considerando-os de mesma área sem, contudo, justificar a congruência. A Figura 59 mostra o desenho com a explicação dada pelo grupo. 


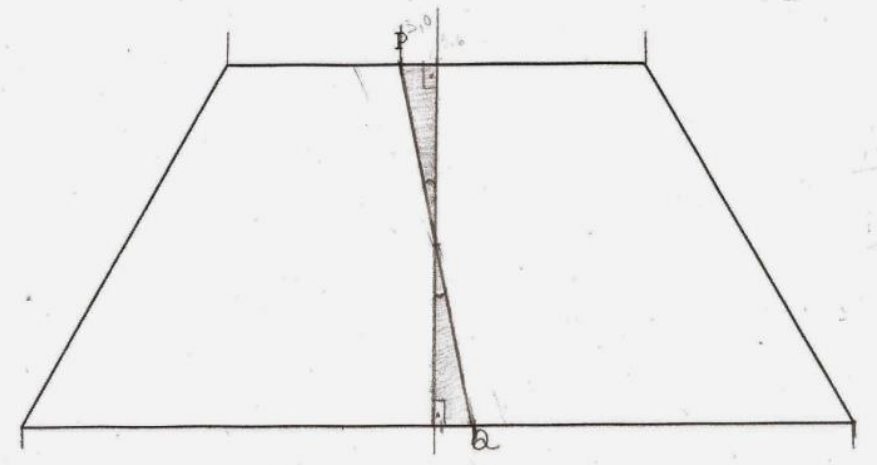

Dividimes o tropézico as

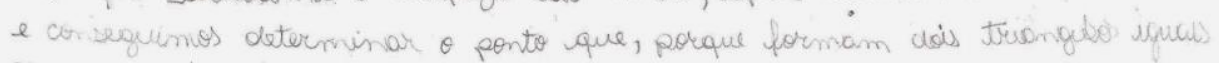

com un tingulo reto

Figura 59: Solução do Grupo G13 - Problema 3, Prova III

\subsubsection{Resultados Fase 3 - Etapa 2}

A última fase do experimento envolvia a resposta a um questionário final (p. 99) que permitiu examinar a maneira como os alunos interpretaram a experiência com Resolução de Problemas e, ainda, a opinião deles em relação ao experimento.

O Questionário Final foi respondido por 67 alunos. Apesar de as perguntas serem abertas, pudemos encontrar uma correlação entre respostas, o que nos permitiu caracterizá-las durante a análise.

Do referido total, apenas quatro alunos não responderam à primeira pergunta. Outros oito deram respostas negativas àquela sobre participação no Rali, pois não houve "ensino" antes de passar os problemas ou apenas por falta de interesse.

Qual sua opinião sobre a participação no Rali e sobre os problemas propostos em cada etapa (grau de dificuldade, interesse, etc.)?

"Eu realmente não vi diferença pois não explicam, passaram problemas antes de ensinar." (25B)

"Alguns exercícios passados necessitam de determinado conhecimento que não possuímos direito, dificultando o fazer dos exercícios." (23B)

"Eu não gosto muito do Rali, faço porque tenho que fazer." (21B)

Quadro 26: Respostas à Questão 1 do Questionário Final 
Para a mesma questão, vinte e seis alunos mencionaram a grande dificuldade que encontraram ao resolver os problemas, evidenciando características positivas e, também, negativas na participação, como consequência.

\section{Qual sua opinião sobre a participação no Rali e sobre os problemas propostos em cada etapa (grau de dificuldade, interesse, etc.)?}

"Eu acredito que os problemas são muito difíceis e fica mais fácil de perder o interesse." (2B)

"Achei muito interessante, porém alguns problemas eram muito difíceis e outros eram muito cansativos de fazer." (49B)

"As provas do Rali foram muito interessantes, o grau de dificuldade foi enorme, foram problemas muito difíceis." (53B)

"Eu gosto dos problemas propostos durantes o Rali - apesar de alguns estarem além da minha capacidade de compreensão." (10B)

"Para mim todos foram difíceis, [...] achei bem interessante e incentivador." (40B)

“[...] Eu achei bem difíceis, mas achei bem legal porque desafia a pular minha dificuldade." (38B)

"Os problemas foram bem difíceis, mas com a participação do grupo conseguimos resolvê-los." (52B)

Quadro 27: Respostas à Questão 1 do Questionário Final

O restante dos alunos avaliou o experimento de forma positiva, salientando aspectos que, para eles, foram relevantes em sua interpretação enquanto participantes. As respostas desses alunos mostram que eles se envolveram com o que foi proposto e perceberam particularidades da atividade de resolver problemas, além da ênfase dadas às representações, como podemos ver no quadro abaixo

Qual sua opinião sobre a participação no Rali e sobre os problemas propostos em cada etapa (grau de dificuldade, interesse, etc.)?

"Eu gosto muito do Rali, os problemas são desafiadores e aí entra a curiosidade, que faz a gente persistir em achar a resposta." (33B)

"Achei interessante e me ajudou a ter um raciocínio diferente com problemas mais difíceis." (28B) 
"Achei interessante, porque percebi que a matemática nem sempre é baseada em fórmulas $e$ equações." (57B)

"O Rali é um trabalho muito bem elaborado (e, aliás, parabéns). Faz você utilizar a cabeça para uma coisa que é fácil, mas te faz pensar." (16B)

"A maioria dos problemas exige raciocínio, o que é bom para as salas." (11B)

"É bem interessante, pois é uma nova proposta de aprendizado em grupo." (48B)

"Meu grupo sempre esteve disposto a chegar nas resoluções, mesmo com certa dificuldade que depois da apresentação de alguns métodos para resoluções ficou muito mais fácil." (26B)

"Na minha opinião gostei do Rali e dos problemas que são propostos, até porque nos ensina a pensar por etapas, utilizar tabelas e etc." (37B)

Quadro 28: Respostas à Questão 1 do Questionário Final

Em relação à segunda questão, conforme as respostas, indicadas pelo Gráfico 2 , vemos que a maioria dos alunos atribuiu notas maiores que 5 à sua participação no grupo durante a resolução dos problemas nas diferentes fases.



Gráfico 2: Resultado Questionário Final - Questão 2

Os alunos que avaliaram a participação com notas entre 0 e 5 justificaram essa resposta considerando-se incapazes de ajudar, pelas dificuldades que têm, ou, ainda, assumindo a falta de interesse pela atividade. Abaixo, vemos alguns comentários que ilustram as respostas desses alunos. 


\begin{tabular}{|c|}
\hline $\begin{array}{c}\text { Dê uma nota de zero a dez para sua participação no grupo durante a resolução dos } \\
\text { problemas do Rali. Justifique. }\end{array}$ \\
\hline 19 notas de 0 a 5 \\
\hline "0- Porque não conseguia ajudar meu grupo, porque não conseguia entender nada!" (55B) \\
"3, tenho dificuldade em matemática por isso não pude ajudar muito." (48B) \\
"4, porque na maioria das vezes eu não conseguia compreender o problema." (66B) \\
"5. Tenho dificuldade em resolver problemas matemáticos, por isso nunca contribuía. ” (32B) \\
"3, pois não achei interessante e não gosto de matemática." (50B) \\
\hline
\end{tabular}

Quadro 29: Respostas à Questão 2 do Questionário Final, notas de 0 a 5

Dos alunos que julgaram que sua participação no grupo com notas de 6 a 9 , muitos ainda mencionaram dificuldades na resolução dos problemas. Entretanto, as respostas da maioria se justificam pelo grande interesse e contribuição dentro do grupo, mesmo que assumam terem cometido erros, não tenham conseguido obter todas as soluções, ou não tenham colaborado plenamente.

\begin{tabular}{|l|}
\hline \multicolumn{1}{|c|}{ Dê uma nota de zero a dez para sua participação no grupo durante a resolução dos } \\
problemas do Rali. Justifique.
\end{tabular}

Quadro 30: Respostas à Questão 2 do Questionário Final, notas de 6 a 9 
Apenas cinco alunos atribuíram nota máxima à participação no grupo. Todos eles relataram dedicação e empenho pessoal, ou do grupo, na busca pelas soluções dos problemas.

\begin{tabular}{|l|}
\hline $\begin{array}{l}\text { Dê uma nota de zero a dez para sua participação no grupo durante a resolução dos } \\
\text { problemas do Rali. Justifique. }\end{array}$ \\
\hline \multicolumn{1}{|c|}{5 notas 10} \\
\hline $\begin{array}{l}\text { "10. Tanto para mim quanto para o grupo. Pois juntando os conhecimentos achamos as respostas." } \\
\text { (29B) } \\
\text { "10, sempre nos esforçamos e tentamos chegar nas respostas." (26B) } \\
\text { "Creio que seja 10, pois eu tento colaborar ao máximo com o grupo. Procuro sempre estar } \\
\text { resolvendo os problemas." (54B) }\end{array}$ \\
\hline
\end{tabular}

Quadro 31: Respostas à Questão 2 do Questionário Final, notas 10

Para análise das respostas da terceira questão, verificamos pontos positivos e negativos separadamente. Ilustramos no Quadro 31 que, a maioria dos alunos avaliou como positiva, na experiência, a forma de trabalho em grupo, as diferentes maneiras de resolver os problemas, em termos das representações, e o tipo de pensamento diferenciado que a atividade proporcionou. Quinze dos 67 alunos que responderam, não mencionaram, ou deixaram claro que não encontraram pontos negativos na experiência.



Quadro 32: Respostas à Questão 3 do Questionário Final, pontos positivos

19 Modo camelinho: termo utilizado pelos alunos para se referir a resoluções que demandam muitos cálculos, geralmente, quando resolvem problemas por meio de tentativas. 
No Quadro 33, vemos alguns exemplos de respostas do que os alunos julgaram como negativo. Entre as respostas, vemos, mais uma vez, que a dificuldade da resolução dos problemas foi mencionada por vários alunos, além do tempo disponível para a atividade e ausência de explicações prévias ou durante a realização das provas - o que era previsto pelas regras do Rali.

\begin{tabular}{|l|}
\hline $\begin{array}{c}\text { Comente os pontos positivos e negativos dessa experiência em resolução de problemas } \\
\text { nos moldes do Rali. } \\
\text { Pontos negativos }\end{array}$ \\
\hline "[...] Já os pontos negativos, acho que temos pouco tempo para resolvê-los." (37B) \\
"Nunca consigo terminar em uma aula." (33B) \\
"Pontos negativos: na dificuldade dos problemas." (49B) \\
"[...] e os pontos negativos é que é muito difícil de resolver e muito cansativo." (12B) \\
"Negativos: tinha vezes que os exercícios 'sugavam', exigiam muito da gente." (54B) \\
"[...] as vezes eu não entendi muito e sentia falta da explicação." (61B)
\end{tabular}

Quadro 33: Respostas à Questão 3 do Questionário Final, pontos negativos 


\section{Capítulo 7}

\section{Considerações Finais}

Iniciamos este trabalho com a motivação de promover uma experiência envolvendo Resolução de Problemas, de modo que essa metodologia fosse incorporada às práticas de sala de aula com seus principais objetivos: proporcionar a descoberta, dar oportunidade de o aluno desenvolver diferentes tipos de raciocínio e estratégias, pensar matematicamente, ampliar seu conhecimento.

Com o desenvolvimento do experimento constituído de três fases, buscamos compreender a maneira como determinados registros de representação subsidiam as atividades de resolução de problemas de alunos do Ensino Médio. Para isso, analisamos as produções dos alunos visando a identificar as principais dificuldades, representações utilizadas, bem como, o papel dessas representações na resolução dos problemas propostos. Além disso, procuramos verificar como as estratégias discutidas, em sala de aula, ao longo da pesquisa seriam reutilizadas por eles.

Na primeira fase, vimos que os alunos são capazes de resolver uma questão que requer apenas a aplicação de uma fórmula (Teorema de Pitágoras), mas não souberam mobilizar os conhecimentos necessários para a resolução de uma questão que exigia a elaboração de uma estratégia diferenciada. Com a Atividade Inicial pudemos evidenciar características que definem a distinção entre um exercício e um problema. Com o Questionário Inicial, pudemos, ainda, perceber que os sujeitos estão mais familiarizados com atividade que se aproximam da resolução de exercícios.

Com a análise dos resultados da Prova I, notamos que, apesar de muitos alunos compreenderem as situações propostas, eles tiveram dificuldade em produzir representações adequadas e úteis para a resolução de um problema. Esse fato ficou ainda mais claro durante as discussões, na Etapa 3 da Fase 1, quando os alunos puderam expor suas ideias iniciais e, com a devida organização, guiados pela pesquisadora, concluíram as soluções.

Percebemos que a presença do registro de representação numérico tabular na Prova II (Fase 2) auxiliou os alunos na obtenção de informações pertinentes para as resoluções dos dois primeiros problemas. A dificuldade para concluir as resoluções se revelou a partir do momento em que foi necessária a conversão do registro numérico 
tabular para o simbólico algébrico, o que já era esperado. De fato, como afirma Duval (2011), trata-se de uma atividade complexa que os alunos não realizam espontaneamente. Assim, é papel do professor propor situações diversas para que se familiarizem com ambos os registros e evoluam em suas articulações.

No problema de Geometria, da mesma prova, observamos que alguns alunos utilizaram a operação de reconfiguração ao subdividir a figura, dada no enunciado, em quadrados de mesma área. As evidências na análise nos levam a considerar que esse procedimento foi influenciado pelas discussões da etapa anterior, isto é, os alunos reutilizaram uma estratégia amplamente discutida. $\mathrm{O}$ mesmo se pode afirmar para o problema de Geometria da Prova III, que também envolve operação de reconfiguração e, para o qual, os alunos também se basearam nas atividades anteriores.

Já na Fase 3, vimos que mesmo sem obter respostas corretas para os dois primeiros problemas da Prova III, grande parte dos grupos apresentou tentativas de representação de um dos tipos discutido nas etapas anteriores, ou, ao menos, uma maneira mais organizada de apresentar os dados e expor suas ideias. Cabe observar que a indicação do tipo de registro a ser utilizado nos problemas da Prova II (numérico tabular) teve um efeito positivo, na medida em que tal registro esteve presente na maioria das soluções apresentadas. E mais, a realização da Prova III ocorreu cerca de dois meses após a devolutiva da segunda prova.

Com a análise das respostas do Questionário Final e, relembrando os encontros no decorrer do desenvolvimento da pesquisa, constatamos que, de maneira geral, a experiência foi válida para os alunos. Eles se mostraram motivados, envolvidos, concentrados em suas próprias ideias e em discuti-las e defendê-las no grupo, tanto na realização das provas, quanto durante as discussões. Muitos alunos concordaram que a experiência de trabalhar em grupo foi motivadora, pois compartilhavam ideias e podiam chegar a conclusões.

Além disso, de certa forma, compreenderam a ênfase dada às diversas formas de representar os problemas. Isso pode ser observado em respostas como:

"Na minha opinião gostei do Rali e dos problemas que são propostos, até porque nos ensina a pensar por etapas, utilizar tabelas e etc."

Enfim, consideramos que os objetivos do trabalho foram atingidos globalmente. Temos que a implementação da Resolução de Problemas e a maneira como as 
atividades foram organizadas permitiram que os alunos vivenciassem a experiência como participantes ativos nos processos de resolução dos problemas. Ainda mais, a escolha pelo contexto do Rali favoreceu o trabalho cooperativo e colaborativo, incentivando os alunos na busca por defender e discutir suas ideias.

Especificamente, obtivemos poucas informações sobre o impacto de se trabalhar as representações semióticas de modo efetivo. Apesar de os alunos reconhecerem o foco e a importância dada às representações, como já mencionado, de maneira geral eles não viam a proposta do Rali e discussões como integradas às aulas regulares de Matemática. Além disso, as intervenções foram pontuais e as representações trabalhadas específicas. Portanto, o experimento não nos permitiu avaliar com clareza até que ponto os sujeitos adquiririam as habilidades necessárias para escolher, utilizar, produzir e manipular certos tipos de representação na construção de conceitos matemáticos e na busca de soluções para problemas diversos.

Os objetivos da pesquisa se uniram à demanda trazida por uma professora da Educação Básica, participante do OBEDUC, para a universidade. Essa integração permitiu a aplicação de novas ideias em sala de aula e, ainda, o aprimoramento e a validação da pesquisa realizada.

Durante o desenvolvimento do experimento, os dados obtidos eram compartilhados com essa professora. Ela própria pode perceber o envolvimento de seus alunos com as atividades propostas. Sendo assim, o trabalho ainda serviu de incentivo à reflexão da docente quanto ao potencial de práticas de Resolução de Problemas e possíveis implicações no desenvolvimento de seus alunos no que se refere à aprendizagem matemática.

Nesse sentido, entendemos que este trabalho contempla os principais objetivos do Mestrado Profissional ${ }^{20}$ :

- Melhorar a qualificação dos professores, contribuindo para a formação de profissionais mais adequados às exigências atuais da Educação Básica;

20 Fonte: www.ime.br/posmpemat. Último acesso: 01 jun 2015. 
- Buscar uma melhor compreensão sobre os objetivos, as dificuldades e os desafios que cercam os processos de ensino-aprendizagem em Matemática;

- Incentivar o professor a tornar-se investigador da própria prática, por meio da discussão de subsídios teóricos que possam embasar uma avaliação contínua de seu trabalho de forma a poder melhor adequá-lo constantemente.

E mais, particularmente, a pesquisa em relação ao tema e a implementação efetiva da experiência em Resolução de Problemas teve grande relevância. Vivenciar tal experiência envolveu dedicação ao preparo das atividades e das devolutivas, à análise atenta dos dados e o cuidado para controlar algumas variáveis de modo que os objetivos fossem atingidos. Todo o trabalho favoreceu, então, uma investigação sobre nossa prática docente e confirmou a motivação inicial de que o ensino de Matemática pode ser baseado na Resolução de Problema. 


\section{Referências}

Allevato, N. S. G. Associando o Computador à Resolução De Problemas Fechados: Análise De Uma Experiência. Tese (Doutorado) - Universidade Estadual Paulista, Rio Claro, 2005, p.37-70.

ALLEVATO, N.S.G.; ONUCHIC, L.R. Ensinando matemática na sala de aula através da resolução de problema. Boletim GEPEM, Rio de Janeiro, Ano XXXIII, n.55, 2009, p.1-19. Disponível em:

$<$ http://www.ufrrj.br/SEER/index.php?journal=gepem\&page=article\&op=view\&path\% 5B\%5D=54\&path\%5B\%5D=87>. Acesso em: 6 out. 2014.

ALVES, A. J. O planejamento de pesquisas qualitativas em educação. Cadernos de Pesquisa, São Paulo, n. 77, 1991. p. 53-61.

BELLEMAIN, P. M. B.; LIMA, P. F. Um estudo da noção de grandeza e implicações no ensino fundamental e médio. Série Textos de História da Matemática, v. 8. Natal: SBHMata, 2002.

BRASIL (país). Ministério da Educação e do Desporto, Secretaria de Educação Fundamental. Parâmetros Curriculares Nacionais: Matemática - $3^{\circ}$ e $4^{\circ}$ ciclos. Brasília: MEC/SEF, 1998.

., Ministério da Educação e do Desporto, Secretaria de Educação Fundamental. PCN+ - Ensino Médio, Orientações Educacionais Complementares aos Parâmetros Curriculares Nacionais: Ciências da Natureza, Matemática e suas Tecnologias. Brasília: MEC/SEF, 2002.

Ministério da Educação. Secretaria de Educação Básica. Orientações Curriculares para o Ensino Médio. Ciências da Natureza, Matemática e suas Tecnologias, v. 2. Brasília: MEC/SEB, 2006.

BOGDAN, R.C.; BIKLEN, S. K. Investigação qualitativa em educação. Porto: Porto Editora, 1994.

CARREIRA, S. P. G. O Papel das Representações na Resolução de Problemas de Matemática Aplicado. In: ABRANTES, P. et al (Org.). Investigações Matemáticas na Aula e no Currículo. Lisboa: APM, 1999. p.253-265.

DAMM, R. F. Registros de Representação. In: MACHADO, S. D. A. et al (Org.). Educação Matemática: Uma introdução. 2. ed. São Paulo: EDUC, 2000. p. 135-153. 
DANTE, L. R. Formulação e resolução de problemas de matemática: teoria e prática. 1. Ed. São Paulo: Ática, 2009.

DUVAL, R. Registros de representações semióticas e funcionamento cognitivo da compreensão em Matemática. In: MACHADO, S. D. A. (Org.). Aprendizagem em Matemática. Campinas: Papirus, 2003.

DUVAL, R. Semiósis e pensamento humano: registro semióticos e aprendizagens intelectuais. Tradução de Lênio Fernandes Levy e Marisa Rosâni Abreu da Silveira. São Paulo: Editora Livraria da Física, 2009

DUVAL, R. Registros de representação semiótica e funcionamento cognitivo do pensamento. Tradução de Méricles Thadeu Moretti. Revista Eletrônica de Matemática, v. 6, n. 2, 2011a. p. 96-112.

Disponível em: <www.periodicos.ufsc.br>. Acesso em: 30 set. 2014.

DUVAL, R. Ver e ensinar a Matemática de outra forma: entrar no modo matemático de pensar: os registros de representações semióticas. Organização: Tânia M. M. Campos. Traduzido por Marlene Alves Dias. 1. ed. São Paulo: PROEM, $2011 \mathrm{~b}$.

DUVAL, R. Gráficos e equações: a articulação de dois registros. Tradução de Méricles Thadeu Moretti. Revista Eletrônica de Matemática, v. 7, n. 2, 2012a. p. 266-297. Disponível em: <www.periodicos.ufsc.br>. Acesso em: 30 set. 2014.

Abordagem cognitiva de problemas de geometria em termos de congruência. Tradução de Méricles Thadeu Moretti. Revista Eletrônica de Matemática, v. 07, n. 1, 2012b. p.118-138.

Disponível em: <www.periodicos.ufsc.br>. Acesso em: 30 mar. 2015.

ECHEVERRÍA, M. P. P; POZO, J. I. Aprender a Resolver Problemas e Resolver Problemas para Aprender. In: POZO, Juan Ignacio (org.). A solução de problemas: Aprender a resolver, resolver para aprender. Tradução de Beatriz Affonso Neves. Porto Alegre: ArtMed, 1998.

FAGNANT, A; VLASSIS, J. Schematic Representations in Arithmetical Problem Solving: Analysis of Their Impact on Grade 4 Students. Educational Studies in Mathematics. Springer, 2013. p. 149-168.

FLORES, Cláudia Regina, Registros de representação semiótica em matemática: história, epistemologia e aprendizagem. Bolema, v. 19, n. 26, 2006. p. 77-102.

FLORES, C. R.; MORETTI, M.T. O papel heurístico de uma figura geométrica: o caso da operação de reconfiguração. In: Anais do VIII Encontro Nacional de Educação Matemática, Recife: UFPE/SBEM, 2004. 
JAHN, A.P.; BONOMI, M. C. Formação de professores de Matemática com resolução de problemas: uma experiência inspirada no Rali Matemático. Anais do XII Encontro Paulista de Educação Matemática: XII EPEM. Birigui: SBEM/SBEM-SP, 2014. p.114.

LAMPERT, M. When the Problem Is Not the Question and the Solution Is Not the Answer: Mathematical Knowingand Teaching. American Educational Research Journal, v.27, n.1. Spring, 1990. p. 29-63.

LESTER, F. O que aconteceu à investigação em resolução de problemas de Matemática? A situação no Estados Unidos. In: D. Fernandes, A. Borralho \& G. Amaro (Org.). Processos cognitivos, concepções de professores e desenvolvimento curricular. Lisboa:IIE, 1994. p. 13-34.

MEDEIROS, K.M. O Contrato Didático e a Resolução de Problemas Matemáticos em Sala de Aula. 1999. Dissertação (Mestrado). Recife: UFPE, 1999.

MENDONÇA, M.C.D. Resolução de Problemas Pede (Re)Formulação. In: ABRANTES, P. et al (Org.). Investigações Matemáticas na Aula e no Currículo. Lisboa: APM, 1999. p.15-33.

NTCM. Standards and Positions. Disponível em: <http://www.nctm.org/>. Acesso em: 3 mar. 2015.

ONUCHIC, L.R.; ALLEVATO, N.S.G. Novas reflexões sobre o ensino-aprendizagem de Matemática através da resolução e problemas. In: BICUDO, M. A. V.; BORBA, M. C. (Org). Educação Matemática - pesquisa em movimento. São Paulo: Cortez, 2004. p. 213-231.

PINTO, N.B. Marcas históricas da matemática moderna no Brasil. Revista Diálogo Educacional, v. 5, n.16, 2005. p.25-38.

POLYA, G. Ensinando por meio de problemas. Revista do Professor de Matemática, n. 7. Rio de Janeiro: SBM, 1985. p. 11-16.

SANTAELLA, L. O que é semiótica. São Paulo: Brasiliense, 2012.

SANTOS, M C. A matemática dos problemas ou o problema da matemática. In: Anais do VI Encontro Nacional de Educação Matemática, São Leopoldo: UNISINOS/SBEM, 1998. p. 241 - 242.

SANTOS, C. A.; CURI, E. Alguns aspectos de articulação entre as teorias da didática francesa e suas contribuições para formação de professores. Revista Eletrônica de Educação Matemática. V4.5, 2009. p.53 - 66.

Disponível em: <www.periodicos.ufsc.br>. Acesso em: 13 mar. 2015 
SÃO PAULO (Estado). Secretaria da Educação. Diretrizes do Programa Ensino Integral. 2012.

Disponível em:

<http://www.educacao.sp.gov.br/a2sitebox/arquivos/documentos/342.pdf>. Acesso em: 21 set. 2014.

SCHOENFELD, A. H. Mathematical Problem Solving. Flórida: Academic Press, 1985.

VAN DE WALLE, J. A. Matemática do Ensino Fundamental: Formação de Professores e Aplicação em Sala de Aula. 6.ed. Porto Alegre: Artmed, 2009. 